AUTARQUIA ASSOCIADA À UNIVERSIDADE DE SÃO PAULO

\title{
VALIDAÇÃO DO MÉTODO DE ANÁLISE POR ATIVAÇÃO COM NÊUTRONS PARA DETERMINAÇÃO DE URÂNIO EM AMOSTRAS AMBIENTAIS
}

NICOLE PEREIRA DE LIMA

Dissertação apresentada como parte dos requisitos para obtenção do Grau de Mestre em Ciências na Área de Tecnologia Nuclear - Aplicações

Orientadora:

Profa. Dra. Mitiko Saiki 
INSTITUTO DE PESQUISAS ENERGÉTICAS E NUCLEARES

Autarquia associada à Universidade de São Paulo

\title{
VALIDAÇÃO DO MÉTODO DE ANÁLISE POR ATIVAÇÃO COM NÊUTRONS PARA DETERMINAÇÃO DE URÂNIO EM AMOSTRAS AMBIENTAIS
}

\author{
NICOLE PEREIRA DE LIMA
}

Dissertação apresentada como parte dos requisitos para obtenção do Grau de Mestre em Ciências na Área de Tecnologia Nuclear - Aplicações

Orientadora:

Profa. Dra. Mitiko Saiki 
Este trabalho é dedicado aos meus pais, Cristiane e José Carmo. 


\section{AGRADECIMENTOS}

À Profa. Dra. Mitiko Saiki pela orientação, generosidade em compartilhar seus conhecimentos e absoluta dedicação a este trabalho.

À minha família pelo carinho e apoio incondicional e ao Alexandre Pinho por existir.

Ao Prof. Dr. Paulo Sergio Cardoso da Silva pela amizade, ajuda e atenção dadas em momentos difíceis.

À Profa. Dra. Vera Akiko Maihara pela companhia e amizade desde o início deste trabalho, além das sugestões feitas como banca do seminário de área.

Ao Prof. Dr. Edson Gonçalves Moreira pela ajuda dada em relação ao cálculo de incertezas, pela atenção e sugestões feitas ao trabalho como banca do seminário de área.

À Profa. Dra. Maria José Aguirre Armelin pela gentileza em me auxiliar em questões referentes a interferência e pela companhia sempre agradável.

À Profa. Dra. Déborah Inês Teixeira Fávaro pelo apoio e ajuda em assuntos concernentes a defesa.

Ao Prof. Dr. Guilherme Soares Zahn por sanar dúvidas de diversas origens, pela amizade e irreverência característica.

Ao Prof. Dr. Frederico Antonio Genezini pelas sugestões dadas e pelas ótimas conversas.

Ao pessoal da operação e manutenção do reator (CRO) e da radioproteção, sem os quais esse trabalho não poderia ser realizado.

Aos amigos Amanda Noyori, Caroline Albuquerque, Caroline Perez, Carolina Theophilo, Eliane Santos, Luan Magalhães, Matheus Angelini, Renata Mendes, Suellen Coutinho, Uanda Paula e em especial ao Bruno Tappiz pelas inúmeras contribuições a este trabalho e, principalmente, pelo apoio e amizade.

Por fim, ao Conselho Nacional de Desenvolvimento Científico e Tecnológico, $\mathrm{CNPq}$, pelo apoio financeiro dado por meio da bolsa de estudos, número do processo 133912/2016-7. 
"Fiz de mim o que não soube E o que podia fazer de mim não o fiz. O dominó que vesti era errado. Conheceram-me logo por quem não era e não desmenti, e perdi-me. Quando quis tirar a máscara, Estava pegada à cara. Quando a tirei e me vi ao espelho, Já tinha envelhecido. Estava bêbado, já não sabia vestir o dominó que não tinha tirado. Deitei fora a máscara e dormi no vestiário Como um cão tolerado pela gerência Por ser inofensivo E vou escrever esta história para provar que sou sublime." (Álvaro de Campos - Fernando Pessoa, 1928) 


\section{RESUMO}

LIMA, Nicole P. Validação do método de análise por ativação com nêutrons para determinação de urânio em amostras ambientais. 2018. 125 p. Dissertação (Mestrado em Tecnologia Nuclear) - Instituto de Pesquisas Energéticas e Nucleares - IPEN-CNEN/SP. São Paulo.

O urânio (U) é considerado um elemento poluente do ambiente devido à sua toxicidade química e radiológica, com propriedades cumulativas em seres humanos, podendo causar diversos tipos de doenças no organismo. Consequentemente, há um grande interesse na determinação de $\mathrm{U}$ em amostras ambientais devido às ações antrópicas como as emissões desse elemento na mineração, nas indústrias e em acidentes nucleares que ocasionam alterações dos seus teores no meio ambiente. Dentre as diversas metodologias analíticas para a determinação de U em amostras ambientais, destaca-se a análise por ativação com nêutrons devido à sua alta sensibilidade e rapidez na análise. O objetivo deste trabalho foi validar o método para a determinação de $\mathrm{U}$ em amostras de biomonitores de cascas de árvores e bromélias, por meio dos procedimentos de análise instrumental por ativação com nêutrons térmicos (INAA) e análise por ativação com nêutrons epitérmicos (ENAA) ambos com irradiações de curta e longa duração no reator nuclear IEA-R1. Para a validação dos resultados com relação à precisão e à exatidão, foram analisados 11 materiais de referência certificados (MRCs), cujos dados foram avaliados por meio dos valores de $\mathrm{Z}$ score e de HorRat. Os procedimentos experimentais consistiram na irradiação térmica e epitérmica de amostras e de padrões de U por períodos de curta e longa duração, seguida de espectrometria de raios gama usando detector de Ge hiperpuro de alta resolução. Os resultados obtidos para a estimativa da incerteza padrão combinada da fração mássica de U, em uma amostra de casca de árvore, mostraram que a fonte de incerteza que mais contribuiu foi a estatística de contagem e o procedimento que apresentou a menor incerteza nos resultados foi a ENAA de longa duração. Os resultados dos MRCs apresentaram, na maioria dos casos, boa precisão e exatidão e as frações mássicas de U determinadas nas cascas de árvores e bromélias apresentaram resultados reprodutíveis. Dentre os quatro procedimentos estudados, a ENAA de longa e curta duração permitiu, em geral, a quantificação de U nas amostras dos materiais analisados. A INAA de longa e de curta duração nem sempre foi efetiva na determinação de U devido ao problema de interferência espectral e do alto valor de limite de detecção. Os limites de detecção determinados pelos procedimentos estudados foram comparados e os menores valores foram obtidos pela ENAA de longa duração. Em virtude dos fatos mencionados, o procedimento mais indicado para a determinação de U nas amostras ambientais analisadas nesse trabalho foi a ENAA de longa duração devido aos seus baixos limites de detecção, boa precisão e exatidão dos resultados e redução do problema de interferência nas análises.

Palavras-chaves: urânio; análise por ativação com nêutrons; validação de método analítico; incerteza; biomonitores. 


\begin{abstract}
LIMA, Nicole P. Validation of neutron activation analysis for uranium determination in environmental samples. 2018. 125 p. Dissertação (Mestrado em Tecnologia Nuclear) - Instituto de Pesquisas Energéticas e Nucleares - IPEN-CNEN/SP. São Paulo.
\end{abstract}

Uranium (U) is an element considered pollutant in the environment due to its radiological and chemical toxicity. This element may cause several kinds of diseases since it presents cumulative properties in the organism. Consequently, there is a great interest in the $\mathrm{U}$ determination in environmental samples that are affected by anthropic actions such as mining, industry and nuclear accidents. Among several analytical methodologies for $U$ determination, neutron activation analysis is considered a sensitive and rapid method. The aim of this study was to validate the method of $U$ determination using the procedures of thermal and epithermal neutron activation analysis (INAA and ENAA) with short and long period of irradiation in the IEA-R1 nuclear reactor for the analysis of biomonitor samples of tree barks and bromeliads. To validate the precision and accuracy of the results, 11 certified reference materials (CRMs) were analyzed. Experimental procedure consisted on irradiating aliquots of the samples and U synthetic standard for short and long period irradiations using thermal and epithermal neutrons, followed by gamma ray spectrometry. Results obtained on the evaluation of the sources of uncertainty showed that statistic of the counting rates was the most relevant in the combined uncertainty of the results. The ENAA using long period irradiation showed the lowest uncertainty. Results obtained in the CRMs showed good precision and accuracy for most of results. In the same way, outcomes obtained for bromeliad and tree bark samples also indicated good reproducibility. Among four procedures of neutron activation analysis, the ENAA using short and long irradiations, in general, allowed to quantify $U$ in the samples analyzed in this study. The INAA using short and long irradiations did not always allow determining $U$ due to the problem of spectral interference and high detection limits. The lowest detection limits for $U$ determination were obtained by ENAA with long period of irradiation. By considering such facts, we conclude that the most appropriate method to determine $U$ in environment sample was ENAA. This is due its low detection limits, good precision, accuracy and also because this method reduce interference in analysis.

Key-words: uranium; neutron activation analysis; validation of analytical method; uncertainty; biomonitors. 


\section{LISTA DE FIGURAS}

Figura 1 - Tabela periódica com informações sobre os elementos que podem ser determinados pela INAA. . . . . . . . . . . . . . . . . . 27

Figura 2 - Esquema do processo de captura de nêutron pelo núcleo alvo seguido por emissões gama. . . . . . . . . . . . . . . . . . . . . 28

Figura 3 - Esquema de decaimento do ${ }^{239} \mathrm{~Np}$. . . . . . . . . . . . . . . . 29

Figura 4 - Representação esquemática do espectro da taxa de fluência de nêutrons em um reator nuclear. . . . . . . . . . . . . . . . . . . . . . 30

Figura 5 - Gráfico da variação da seção de choque do ${ }^{238} \mathrm{U}$ em função a energia do nêutron incidente para reações $(n, \gamma)$ e $(n, f) \ldots \ldots . \ldots 35$

Figura 6 - Mapa da localização dos pontos de amostragem das cascas de árvores. . 41

Figura 7 - Fotografia mostrando a solução padrão sendo pipetada em tiras de papel de filtro. . . . . . . . . . . . . . . . . . 43

Figura 8 - Fotografia do padrão e das alíquotas de amostras em envelopes de polietileno. 44

Figura 9 - Fotografia do dispositivo de alumínio, suporte de aço inoxidável, padrão e amostras em envelopes de polietileno embrulhadas em folha de alumínio.

Figura 10 - Fotografia do dispositivo de alumínio, suporte de aço inoxidável, cápsula de cádmio, padrão e amostras em envelopes de polietileno embrulhadas em folha de alumínio.

Figura 11 - Fotografia do dispositivo de polietileno, suporte de aço inoxidável, padrão e amostras em envelopes de polietileno. . . . . . . . . . . .

Figura 12 - Fotografia do dispositivo de polietileno, suporte de aço inoxidável, cápsula de cádmio, calço de espuma de nylon, padrão e amostras em envelopes de polietileno. . . . . . . . . . . . . . . . . . . .

Figura 13 - Diagrama de Ishikawa para a determinação da incerteza combinada da fração mássica de elementos por INAA ou ENAA. . . . . . . . . . . . .

Figura 14 - Porcentagem da contribuição da incerteza padrão combinada da massa da amostra de casca de árvore por procedimento utilizado. . . . . . . . . .

Figura 15 - Porcentagem da contribuição da incerteza padrão combinada da massa do elemento no padrão por procedimento utilizado.

Figura 16 - Porcentagem da contribuição da incerteza padrão das constantes de decaimento por procedimento utilizado. . . . . . . . . . . . . . .

Figura 17 - Porcentagem da contribuição da incerteza padrão da atividade da amostra de casca de árvore por procedimento utilizado. . . . . . . . . . . . . . .

Figura 18 - Porcentagem da contribuição da incerteza padrão da atividade do padrão por procedimento utilizado. . . . . . . . . . . . . . . . . 
Figura 19 - Porcentagem de incerteza na fração mássica de U determinada por diferentes procedimentos analíticos. . . . . . . . . . .

Figura 20 - Valores de Z scores para as frações mássicas de U nos materiais de referência certificados obtidos por INAA de curta duração.

Figura 21 - Valores de HorRat para as frações mássicas de U nos materiais de referência certificados obtidos por INAA de curta duração. . . . . . . . . . . .

Figura 22 - Valores de Z score para as frações mássicas de U nos materiais de referência certificados obtidos por ENAA de curta duração. . . . . . . . . . . .

Figura 23 - Valores de HorRat para as frações mássicas de U nos materiais de referência certificados obtidos por ENAA de curta duração. . . . . . . . . . . .

Figura 24 - Valores de Z score para as frações mássicas de U nos materiais de referência certificados obtidos por INAA de longa duração com 7 dias de decaimento. . . . . . . . . . . . . . . . .

Figura 25 - Valores de Z score para as frações mássicas de U nos materiais de referência certificados obtidos por INAA de longa duração com 9 dias de decaimento.

Figura 26 - Valores de HorRat para as frações mássicas de U nos materiais de referência certificados obtidos por INAA de longa duração com 7 dias de decaimento.

Figura 27 - Valores de HorRat para as frações mássicas de U nos materiais de referência certificados obtidos por INAA de longa duração com 9 dias de decaimento. . . . . . . . . . . . . . . . 75

Figura 28 - Espectro do MRC “IAEA - SOIL - 7” obtido por INAA de longa duração. 75

Figura 29 - Espectro do MRC "INCT - OBTL - 5" obtido por INAA de longa duração. 76

Figura 30 - Valores de Z score para as frações mássicas de U nos materiais de referência certificados obtidos por ENAA de longa duração com 2 dias de decaimento.

Figura 31 - Valores de Z score para as frações mássicas de U nos materiais de referência certificados obtidos por ENAA de longa duração com 4 dias de decaimento.

Figura 32 - Valores de HorRat para as frações mássicas de U nos materiais de referência certificados obtidos por ENAA de longa duração com 2 dias de decaimento. . . . . . . . . . . . . . . . .

Figura 33 - Valores de HorRat para as frações mássicas de U nos materiais de referência certificados obtidos por ENAA de longa duração com 4 dias de decaimento. . . . . . . . . . . . . . . . . 80

Figura 34 - Espectro do MRC "IAEA - SOIL - 7" obtido por ENAA de longa duração. 80

Figura 35 - Espectro do MRC "INCT - M3" obtido por ENAA de longa duração. . . . 81

Figura 36 - Valores de HorRat para as frações mássicas de U nas cascas de árvores obtidas por ENAA de curta duração. . . . . . . . . . . . . . . . 
Figura 37 - Valores de HorRat para as frações mássicas de U nas cascas de árvores obtidas por INAA de longa duração. . . . . . . . . . . . . . . . .

Figura 38 - Valores de HorRat para as frações mássicas de U nas cascas de árvores obtidas por ENAA de longa duração com 2 dias de decaimento. . . . . . . 87

Figura 39 - Valores de HorRat para as frações mássicas de U nas cascas de árvores obtidas por ENAA de longa duração com 4 dias de decaimento. . . . . . . 87

Figura 40 - Valores de HorRat para as frações mássicas de U nas amostras de bromélias obtidas por ENAA de curta duração. . . . . . . . . . . . . . . . . . 88

Figura 41 - Valores de HorRat para as frações mássicas de U nas amostras de bromélias obtidas por INAA de longa duração. . . . . . . . . . . . . . . . .

Figura 42 - Valores de HorRat para as frações mássicas de U nas amostras de bromélias obtidas por ENAA de longa duração com 2 dias de decaimento. . . . . . . 91

Figura 43 - Valores de HorRat para as frações mássicas de U nas amostras de bromélias obtidas por ENAA de longa duração com 4 dias de decaimento. . . . . . .

Figura 44 - Representação "box plot" das frações mássicas de U nas amostras de cascas de árvores determinadas por ENAA de curta duração e INAA e ENAA de longa duração. . . . . . . . . . . . . . . . . . . . . . 97

Figura 45 - Representação "box plot" das frações mássicas de U nas amostras de cascas de árvores determinadas por ENAA de curta duração e INAA e ENAA de longa duração. . . . . . . . . . . . . . . . . . . . . . . . . 98

Figura 46 - Representação "box plot" das frações mássicas de U em amostras bromélias determinadas por ENAA de curta duração e INAA e ENAA de longa duração. . . . . . . . . . . . . . . . . . . .

Figura 47 - Limites de detecção de U obtidos na análise de materiais de referência certificados. . . . . . . . . . . . . . . . 100

Figura 48 - Limites de detecção de U obtidos na análise de amostras cascas de árvores. 101

Figura 49 - Limites de detecção de U obtidos na análise de amostras de bromélias. . . 101 


\section{LISTA DE TABELAS}

Tabela 1 - Valores de seção de choque e integral de ressonância de isótopos estáveis e elementos ....................... 32

Tabela 2 - Dados dos materiais de referência certificados utilizados neste trabalho . 38

Tabela 3 - Porcentagem de umidade nos materiais de referência certificados . . . . 39

Tabela 4 - Dados das amostras de cascas de árvores coletadas na Cidade Universitária. 42

Tabela 5 - Dados da solução padrão e da massa de U irradiada. . . . . . . . . . . . 44

Tabela 6 - Fontes de incerteza e parâmetros para a determinação da incerteza combinada da fração mássica de U por INAA e ENAA. . . . . . . . . . . . . 55

Tabela 7 - Resultados obtidos na verificação da calibração do pipetador automático. 56

Tabela 8 - Limites de detecção (LD) e de quantificação (LQ) de $U$ (ng $\mathrm{g}^{-1}$ ) nos envelopes de polietileno por ENAA de curta e longa duração. . . . . . . . 57

Tabela 9 - Limites de detecção (LD) e de quantificação (LQ) de $U\left(\right.$ ng g $^{-1}$ ) no papel de filtro Whatman $\mathrm{N}^{o} 40$ por ENAA de curta e longa duração. . . . . . . . 57

Tabela 10 - Valores das contribuições da incerteza padrão combinada da massa da amostra. . . . . . . . . . . . . . . . 58

Tabela 11 - Valores das contribuiçõos da incerteza padrão combinada da massa do elemento no padrão. . . . . . . . . . . . . . . . . . . . . 60

Tabela 12 - Valores das incertezas padrão das constantes de decaimento. . . . . . . . 62

Tabela 13 - Frações mássicas de U (ng g $\left.{ }^{-1}\right)$ em materiais de referência certificados obtidas por INAA de curta duração. . . . . . . . . . . . . . . . .

Tabela 14 - Frações mássicas de $\mathrm{U}\left(\mathrm{ng} \mathrm{g}^{-1}\right)$ em materiais de referência certificados obtidas por ENAA de curta duração. . . . . . . . . . . . . . . . . .

Tabela 15 - Frações mássicas de U (ng $\left.\mathrm{g}^{-1}\right)$ em materiais de referência certificados obtidas por INAA de longa duração. . . . . . . . . . . . . . . .

Tabela 16 - Frações mássicas de U $\left(\mathrm{ng} \mathrm{g}^{-1}\right)$ em materiais de referência certificados obtidas por ENAA de longa duração. . . . . . . . . . . . . . . . . 77

Tabela 17 - Frações mássicas de $\mathrm{U}\left(\mathrm{ng} \mathrm{g}^{-1}\right)$ determinadas em cascas de árvores por INAA e ENAA de curta duração. . . . . . . . . . . . . . . . . .

Tabela 18 - Frações mássicas de $\mathrm{U}\left(\mathrm{ng} \mathrm{g}^{-1}\right)$ determinadas em cascas de árvores por INAA de longa duração com tempo de decaimento de 7 dias. . . . . . .

Tabela 19 - Frações mássicas de $\mathrm{U}\left(\mathrm{ng} \mathrm{g}^{-1}\right)$ determinadas em cascas de árvores por ENAA de longa duração.

Tabela 20 - Frações mássicas de U ( $\left.\mathrm{ng} \mathrm{g}^{-1}\right)$ em amostras de bromélias obtidas por INAA e ENAA de curta duração. . . . . . . . . . . . . . . . . . . .

Tabela 21 - Frações mássicas de U ( $\mathrm{ng} \mathrm{g}^{-1}$ ) em amostras de bromélias obtidas por INAA de longa duração com tempo de decaimento de 7 dias. . . . . . . . 
Tabela 22 - Frações mássicas de $\mathrm{U}\left(\mathrm{ng} \mathrm{g}^{-1}\right)$ em amostras de bromélias obtidas por ENAA de longa duração. . . . . . . . . . . . . . . . . . . 92

Tabela 23 - Comparação entre os resultados das amostras de cascas de árvores obtidos pela ENAA de curta duração e INAA e ENAA de longa duração realizada pela análise de variância (ANOVA) e pelo teste de Tukey. . . . . . . . . 95

Tabela 24 - Comparação entre os resultados das amostras de bromélias obtidos pela ENAA de curta duração e INAA e ENAA de longa duração realizada pela análise de variância (ANOVA) e pelo teste de Tukey. . . . . . . . . . . . 96 


\section{LISTA DE ABREVIATURAS E SIGLAS}

ANOVA Análise de Variância

CEPE-USP Centro de Práticas Esportivas da Universidade de São Paulo

CNEN Comissão Nacional de Energia Nuclear

CUASO Cidade Universitária Armando Salles de Oliveira

DGNAA Análise por Ativação com Nêutrons de Raios Gama Retardados

ENAA Análise por Ativação com Nêutrons Epitérmicos

ETAAS Espectrometria de Absorção Atômica Eletrotérmica

FAAS Espectrometria de Absorção Atômica de Chama

IAEA International Atomic Energy Agency

IAG-USP Instituto de Astronomia, Geofísica e Ciências Atmosféricas da Universidade de São Paulo

ICP-MS Espectrometria de Massa com Fonte de Plasma Acoplado Indutivamente

ICP-OES Espectrometria de Emissão Ótica Acoplada com Fonte de Plasma Acoplado Indutivamente

INAA Análise Instrumental por Ativação com Nêutrons

INCT Institute of Nuclear Chemistry and Technology

IPEN Instituto de Pesquisas Energéticas e Nucleares

LAN Laboratório de Análise por Ativação Neutrônica

LSC Método de Contagem por Cintilação Líquida

MRC Material de Referência Certificado

NAA Análise por Ativação com Nêutrons

NIST National Institute of Standards and Technology

RNAA Análise por Ativação com Nêutrons com Separação Radioquímica

XRFS Espectrometria de Raios X 


\section{SUMÁRIO}

INTRODUÇÃO . . . . . . . . . . . . . . 16

OBJETIVOS $\ldots \ldots \ldots \ldots \ldots \ldots \ldots \ldots \ldots \ldots$

REVISÃO BIBLIOGRÁFICA . . . . . . . . . . . . .

FUNDAMENTOS TEÓRICOS DA ANÁLISE POR ATIVAÇÃO COM

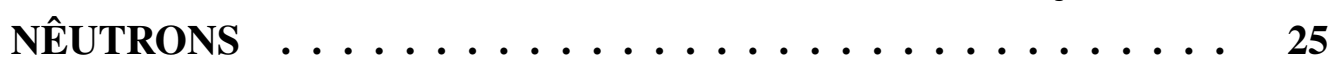

4.1 História do desenvolvimento da análise por ativação com nêutrons . 25

4.2 Princípio do método de análise por ativação com nêutrons . . . . . 26

$4.2 .1 \quad$ Integral de ressonância . . . . . . . . . . . . . . . . 30

4.3 Equação fundamental da análise por ativação com nêutrons . . . . . 32

4.4 Determinação de urânio pelo método de análise por ativação com nêu-

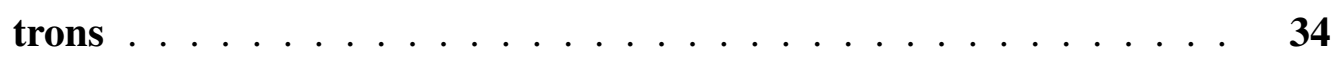

4.5 Interferências na determinação de elementos em análise por ativação com nêutrons . . . . . . . . . . . . . . . . . . 36

MATERIAIS E MÉTODOS $\ldots \ldots \ldots$. . . . . . . . . 37

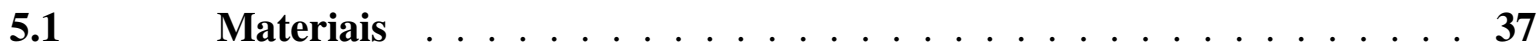

5.1.1 Materiais de referência certificados . . . . . . . . . . . 37

5.1.1.1 Determinação da umidade nos materiais de referência certificados . . . . 38

5.1.2 Amostras de biomonitores . . . . . . . . . . . . . . . . 40

5.1.2.1 Coleta das amostras de cascas de árvores . . . . . . . . . . . . 40

5.1.2.2 Tratamento das amostras de cascas de árvores . . . . . . . . . . . 41

5.1.3 Amostras de bromélias . . . . . . . . . . . . . . . . 42

5.1.4 Preparo do padrão sintético de urânio . . . . . . . . . . . . . 43

5.1.5 Pesagem dos materiais de referência certificados e das amostras para análise 44

$5.2 \quad$ Verificação da calibração do pipetador . . . . . . . . . . . 44

$5.3 \quad$ Ensaios preliminares $\ldots \ldots \ldots \ldots \ldots \ldots$

5.3.1 Determinação de urânio como impureza em envelopes de polietileno usados na irradiação de amostras e padrões . . . . . . . . . . . . . 45

5.3.2 Determinação de urânio como impureza no papel de filtro usado como suporte no preparo do padrão sintético . . . . . . . . . . . . 45

$5.4 \quad$ Procedimento de análise por ativação com nêutrons . . . . . . . . . 46

5.4.1 Irradiações de longa duração . . . . . . . . . . . . . . . . 46

5.4.1.1 Análise instrumental por ativação com nêutrons térmicos de longa duração 46

5.4.1.2 Análise por ativação com nêutrons epitérmicos de longa duração . . . . 47 
5.4.2 Irradiações de curta duração . . . . . . . . . . . . . . . . . 48

5.4.2.1 Análise instrumental por ativação com nêutrons térmicos de curta duração 48

5.4.2.2 Análise por ativação com nêutrons epitérmicos de curta duração . . . . . 49

6 TRATAMENTO DE DADOS $\ldots \ldots \ldots \ldots \ldots \ldots \ldots$

6.1 Diferença padronizada $(Z$ score $) \ldots \ldots \ldots \ldots$

$6.2 \quad$ Valor de HorRat $\ldots \ldots \ldots \ldots \ldots \ldots$

$6.3 \quad$ Limites de detecção e de quantificação $\ldots \ldots \ldots \ldots$

$6.4 \quad$ Teste de Grubbs . . . . . . . . . . . . . . . . . . . . . . 51

$6.5 \quad$ Análise de variância (ANOVA) $\ldots \ldots \ldots \ldots \ldots$

$6.5 .1 \quad$ Teste de Tukey . . . . . . . . . . . . . . . 52

6.6 Estimativa da incerteza da determinação de um elemento pela análise por ativação com nêutrons . . . . . . . . . . . . . . . . . . . . 53

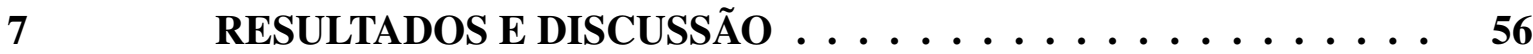

7.1 Resultado da verificação da calibração do pipetador . . . . . . . . . 56

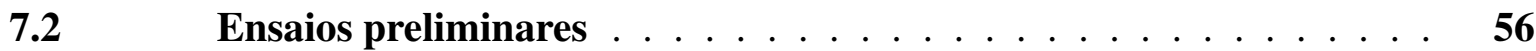

7.2.1 Determinação de urânio como impureza em envelopes de polietileno usados na irradiação de amostras e padrões . . . . . . . . . . . . . . . . 56

7.2.2 Determinação de urânio como impureza na tira de papel de filtro usado como suporte para irradiação do padrão sintético . . . . . . . . . . . . . . 57

7.3 Resultados da quantificação dos componentes da incerteza da determinação de urânio pela análise por ativação com nêutrons . . . . . . 58

7.3.1 Incerteza padrão combinada da massa da amostra de casca de árvore . . 58

7.3.2 Incerteza padrão combinada da massa do elemento no padrão sintético de U 59

7.3.3 Incerteza da constante de decaimento . . . . . . . . . . . . . . 61

7.3.4 Incerteza padrão combinada da atividade da amostra de casca de árvore e do padrão de U . . . . . . . . . . . . . . . . . . . . . . . . 62

7.3.5 Comparação entre as incertezas da determinação de urânio em amostra de casca de árvore obtidas por diferentes procedimentos analíticos . . . . . 64

7.4 Resultados da determinação de urânio em materiais de referência certificados .......................... 65

7.4.1 Irradiações de curta duração de materiais de referência certificados . . . 65

7.4.1.1 Análise por ativação com nêutrons térmicos de curta duração . . . . . . 65

7.4.1.2 Análise por ativação com nêutrons epitérmicos de curta duração . . . . . 68

7.4.2 Irradiações de longa duração de materiais de referência . . . . . . . . . 71

7.4.2.1 Análise por ativação com nêutrons térmicos de longa duração . . . . . . . 71

7.4.2.2 Análise por ativação com nêutrons epitérmicos de longa duração . . . . 76

7.5 Resultados da determinação de urânio em amostras de cascas de árvores 
7.5.1 Irradiações de curta duração de amostras de cascas de árvores . . . . . . . 81

7.5.1.1 Análise por ativação com nêutrons térmicos e epitérmicos de curta duração 81

7.5.2 Irradiações de longa duração de amostras de cascas de árvores . . . . . . 83

7.5.2.1 Análise por ativação com nêutrons térmicos de longa duração . . . . . . 83

7.5.2.2 Análise por ativação com nêutrons epitérmicos de longa duração . . . . 85

7.6 Resultados da determinação de urânio em amostras de bromélias . . 88

7.6.1 Irradiações de curta duração de amostras de bromélias . . . . . . . . . 88

7.6.1.1 Análise por ativação com nêutrons térmicos e epitérmicos de curta duração 88

7.6.2 Irradiações de longa duração de amostras de bromélias . . . . . . . . . . 89

7.6.2.1 Análise por ativação com nêutrons térmicos de longa duração . . . . . . 89

7.6.2.2 Análise por ativação com nêutrons epitérmicos de longa duração . . . . . 91

7.7 Comparação entre resultados das frações mássicas de urânio obtidas em amostras de biomonitores por diferentes procedimentos de análise por ativação com nêutrons . . . . . . . . . . . . . . . . . . . 93

7.7.1 Aplicação da ANOVA às médias das frações mássicas de urânio obtidas em amostras de biomonitores por diferentes procedimentos de análise por ativação com nêutrons . . . . . . . . . . . . . . . . . . . . . 94

7.7.2 Comparação dos limites de detecção obtidos em materiais de referência certificados e amostras por diferentes procedimentos . . . . . . . . . 100

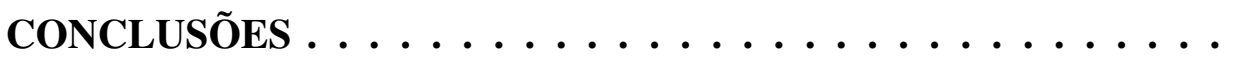

REFERÊNCIAS BIBLIOGRÁFICAS . . . . . . . . 106

APÊNDICE A - TABELAS DE RESULTADOS INDIVIDUAIS DAS FRAÇÕES MÁSSICAS DE U EM MATERIAIS DE REFERÊNCIA CERTIFICADOS . . . . . 114

APÊNDICE B - TABELAS DE RESULTADOS INDIVIDUAIS DAS FRAÇÕES MÁSSICAS DE U EM AMOSTRAS DE CASCAS DE ÁRVORES . . . . . . . . . 120

APÊNDICE C - TABELAS DE RESULTADOS INDIVIDUAIS DAS FRAÇÕES MÁSSICAS DE U EM AMOSTRAS DE

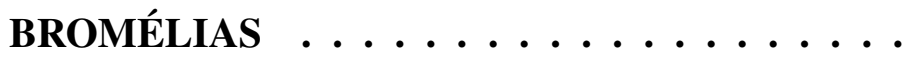




\section{INTRODUÇÃO}

O urânio (U) é um elemento químico pertencente à família dos actinídeos. Este elemento pode ser encontrado no solo com frações mássicas que variam de 0,1 a $20 \mu \mathrm{g} \mathrm{g}^{-1}$, dependendo da região (SAHOO et al., 2008). Além disso, o U também está presente na água, no ar e nos alimentos. Seu teor no ambiente depende, inicialmente, da formação geológica e das características geográficas da região, onde ocorrem processos geoquímicos que reciclam o material presente na crosta com o manto terrestre (SINGH et al., 2001).

Este elemento pode ser encontrado em mais de 100 minerais distintos como componente de depósitos minerais, por exemplo, granitos, rochas metamórficas, lignito, areia monazítica e fosfatos (KEITH et al., 2007; CDW, 2017; HAYNES, 2014). O U natural é formado por três radioisótopos alfa emissores com abundância isotópica de 99,275\% para ${ }^{238} \mathrm{U}, 0,720 \%$ para ${ }^{235} \mathrm{U}$ e $0,006 \%$ para ${ }^{234} \mathrm{U}$ (HAYNES, 2014).

O U se oxida quando em contato com o ar, de maneira que ele nunca é observado sozinho na natureza. Em outras palavras, ele sempre se combina com outros elementos. Ademais, este elemento existe em seis estados de oxidação $(0,+2,+3,+4,+5$ e +6$)$, sendo o estado hexavalente o mais estável em solução e relevante biologicamente (KEITH et al., 2007; CDW, 2017).

A mobilidade do U no ambiente depende de sua forma física e química. Variáveis como o seu estado de oxidação, $\mathrm{pH}$, solubilidade, presença de ligantes orgânicos ou inorgânicos e a possibilidade de adsorção em sedimentos superficiais da água são determinantes na mobilidade deste elemento. A solubilidade das formas oxidadas do U permite, por meio de intemperismos e da lixiviação, a transferência do mesmo de rochas para água e consequentemente para plantas e animais, entrando assim na cadeia alimentar (ATSDR, 2011; CDW, 2017).

O teor de U no meio ambiente também é alterado por ações antrópicas. São elas, por exemplo, as emissões da indústria nuclear (LANDSBERGER; KAPSIMALIS, 2013), a combustão de carvão e combustíveis fósseis (ESSIEN et al., 1985; CDW, 2017), o uso de fertilizantes fosfatados na agricultura, cujas frações mássicas podem chegar a $150 \mathrm{mg} \mathrm{kg}-1$ (CDW, 2017), testes de armamentos nucleares (Atol Moruroa e Semipalatinsk), acidentes nucleares (Chernobyl, Palomares e Thule) e derramamento de lixo radioativo (Sellafield, La Hague e Moyak) (SRNCIK et al., 2011). A emissão de U em conflitos militares como a guerra do Golfo, no Kuwait, e a guerra do Kosovo, na Sérvia, inspirou diversos trabalhos devido à sua relevância e consequências, como os de McDiarmid et al. (2004), Bem e Bou-Rabee (2004), Papastefanou (2002) e Parrish et al. (2008).

O crescente interesse na determinação de $\mathrm{U}$ em amostras de matrizes ambientais 
é justificado pela dispersão deste elemento no meio ambiente decorrente das atividades antrópicas, além de sua toxicidade oferecer riscos à saúde humana.

No organismo humano, o U não exerce funções metabólicas e, deste modo, não é considerado um elemento essencial (CDW, 2017). Este elemento possui toxicidade química e radiológica, sendo a toxicidade radiológica diferente para cada radioisótopo (CDW, 2017). Em decorrência do U apresentar uma atividade natural baixa, os efeitos de sua toxicidade radiológica não são considerados relevantes quando comparados com os efeitos de sua toxicidade química (BRUGGE; BUCHNER, 2011). Isso se deve à sua tendência em se concentrar em locais específicos, podendo aumentar o risco de doenças nos ossos, fígado, cérebro, corrente sanguínea e nos rins (KEITH et al., 2007).

Devido à capacidade de se acumular no organismo, o U pode permanecer no corpo humano por longos períodos de tempo, dependendo dos órgãos afetados e da rota de exposição, causando danos irreversíveis. Nos ossos, este elemento se deposita de maneira similar ao cálcio e aos metais alcalinos terrosos, incorporando-se na matriz óssea (BRUGGE et al., 2005; BRUGGE; BUCHNER, 2011). Ademais, o U pode ocasionar envenenamento de baixa intensidade, gerando sintomas como náuseas, dores de cabeça, vômitos e diarreias (SAWICKI et al., 2008).

Como o U é um elemento radioativo, ele pode ser considerado um agente carcinogênico. Seus efeitos genotóxicos são gerados por suas propriedades químicas e radiológicas, e os danos causados ao DNA estão associados às inúmeras doenças além do câncer, como doenças hereditárias e congênitas (BRUGGE; BUCHNER, 2011; BANNING; BENFER, 2017)

Na natureza, os radionuclídeos mais abundantes são o ${ }^{238} \mathrm{U}$, o ${ }^{232} \mathrm{Th}$ e o ${ }^{40} \mathrm{~K}$ (SHTANGEEVA, 2010). Enquanto alguns deles são absorvidos pelas plantas como homólogos a elementos essenciais, outros são depositados independentemente de exercer função biológica naquele organismo (KARUNAKARA et al., 2003).

O depósito desses radioisótopos nas plantas ocorre por dois processos complexos e distintos, sendo eles a acumulação interna e o depósito superficial (CATINON et al., 2009). No primeiro caso, os elementos são absorvidos pela raiz da planta advindos do solo, dos lençóis freáticos e do substrato rochoso e o teor destes elementos vai depender da capacidade dessa planta absorver, transportar e acumular os mesmos em diferentes partes do seu organismo (raízes, caule, cascas, galhos, folhas e flores)(RAJU; RAJU, 2000).

No caso do depósito superficial, as cascas de árvores podem acumular grandes quantidades de poeira atmosférica. A retenção desse material particulado ocorre devido à umidade, à aspereza e à superfície eletricamente carregada da casca em contato com o ambiente (CATINON et al., 2009). Por esses motivos, amostras de cascas de árvores, bromélias, musgos, fungos e liquens são considerados, de acordo com a literatura, biomonitores adequados para a avaliação de U no meio ambiente (BELLIS et al., 2001; MÄRTEN et al., 2015; ROSAMILIA 
et al., 2004).

Existem inúmeros métodos analíticos apropriados para a detecção e quantificação de $\mathrm{U}$ em diversos tipos de matrizes. Eles são classificados em métodos de medida in situ e métodos de laboratório (BORYŁO, 2013). Dentre os métodos de laboratório, têm-se os radiométricos e não radiométricos. Como exemplo de métodos não radiométricos para a detecção de U em amostras ambientais, tem-se a espectrometria de massa com fonte de plasma acoplado indutivamente (ICP-MS) (HIMRI et al., 2000; BOULYGA et al., 2001), a espectrometria de fluorescência de raios X (XRFS) (O’MEARA et al., 1998; SINGER et al., 2009), a espectrometria de absorção atômica de chama (FAAS) (SANTOS et al., 2010), a espectrometria de absorção atômica eletrotérmica (ETAAS)(SANTOS et al., 2010) e a espectrometria de emissão ótica acoplada com fonte de plasma acoplado indutivamente (ICP-OES) (SANTOS et al., 2010; DANESHVAR et al., 2009).

Com relação aos métodos radiométricos, pode-se citar a análise por ativação com nêutrons (NAA): instrumental (INAA) (PULHANI et al., 2000; ZIKOVSKY, 2006; LANDSBERGER; KAPSIMALIS, 2013), epitérmica (ENAA), com separação radioquímica (RNAA) (KUČERA et al., 2000; DYBCZYNSKI et al., 2007) e pela medida de raios gama retardados (DGNAA)(GROGAN; O'KELLY, 2014). Há ainda o método de contagem por cintilação líquida (LSC) (BAIK et al., 2015; ZHOU et al., 2015), a espectrometria gama (KARANGELOS et al., 2004) e a espectrometria alfa (BORYŁO, 2013; JIA et al., 2002).

A escolha de um método adequado para a determinação de $\mathrm{U}$ em amostras ambientais depende do tipo de matriz, da quantidade de amostra disponível e do teor de U presente na mesma. Além disso, cada um desses métodos apresenta vantagens e desvantagens em relação ao tempo requerido para a análise, ao problema de interferência, à qualidade dos resultados e ao custo da análise. Neste cenário, observa-se a NAA como uma metodologia analítica sensível, multielementar, rápida e aplicável para análise de amostras de diferentes tipos de matrizes, além de fornecer resultados com alta precisão e exatidão, também é considerado um método com alto padrão metrológico (GREENBERG et al., 2011). Ademais, a infraestrutura existente no Laboratório de Análise por Ativação com Nêutrons (LAN) do IPEN-CNEN/SP, onde se encontra o reator de pesquisa IEA-R1, permite a aplicação da NAA na determinação de U nos mais variados tipos de amostras. Nesse contexto, julgou-se necessária a realização de um estudo para avaliar a eficácia do método na determinação de U, bem como a qualidade dos resultados obtidos por INAA e ENAA, usando irradiações de curta e longa duração.

Para a determinação de $\mathrm{U}$ em amostras ambientais de origem biológica, cuja fração mássica é baixa (da ordem de $1 \mu \mathrm{g} \mathrm{g}^{-1}$ ), é necessário realizar um controle de qualidade dos resultados com relação à precisão e a exatidão para assegurar a obtenção de resultados confiáveis. Esse controle de qualidade pode ser realizado por meio do cálculo da incerteza de medição e pela validação da metodologia. 
A incerteza pode ser definida como variável, associada ao resultado de uma medição, que caracteriza a dispersão dos valores que podem ser razoavelmente atribuídos ao mensurando (JCGM-INMETRO, 2008). Portanto, a incerteza é um parâmetro que define a qualidade dos resultados das medições. Dentre os diversos trabalhos sobre avaliação da incerteza aplicada a NAA, destacam-se os de Greenberg et al. (2000), Heydorn (2000), Osterc e Stibilj (2005), Moreira et al. (2005), Moreira et al. (2006) e Greenberg et al. (2011).

A validação é um processo de grande importância nas análises químicas e pode ser definida como a confirmação por ensaios e o fornecimento de provas objetivas de que determinados requisitos são cumpridos para seu uso proposto (EURACHEM, 1998). Logo, a validação fornece credibilidade à metodologia e gera evidência documentada de que o método realiza aquilo para o qual ele é indicado (INMETRO, 2012). A validação pode ser realizada pela análise de materiais de referência, pois, dessa maneira, é possível determinar parâmetros relativos à performance do método (BALLA et al., 2004). Na literatura, encontramse trabalhos que abordam o tema da validação do método NAA, como os artigos Heydorn (1995), Balla et al. (2004) e Acharya et al. (2002).

Deste modo, levando em consideração os aspectos até então apresentados, a proposta deste trabalho foi o estabelecimento de condições analíticas para a determinação da fração mássica de $U$, isto é, a validação dos procedimentos analíticos usando materiais de referência certificados (MRCs) e o cálculo de incerteza de medição pelos métodos de análise por ativação com nêutrons térmicos e epitérmicos.

Uma vez estabelecidos os procedimentos analíticos, eles foram aplicados na determinação de U em amostras ambientais de biomonitores, como cascas de árvores das espécies Tipuana tipu (Tipuana) e Poincianella pluviosa (Sibipiruna) e de bromélias da espécie Tillandsia usneoides L. . Amostras dessas espécies já foram utilizadas como biomonitores de poluição atmosférica nos trabalhos Figueiredo et al. (2007), Geraldo et al. (2014), Moreira et al. (2016) e Amato-Lourenco et al. (2016). 


\section{OBJETIVOS}

O objetivo deste trabalho foi realizar um estudo comparativo e aprimorar a determinação de $\mathrm{U}$ em amostras ambientais pelos métodos de análise instrumental por ativação com nêutrons térmicos (INAA) e análise por ativação com nêutrons epitérmicos (ENAA), ambos por meio de irradiações de curta e longa duração no reator nuclear IEA-R1. São objetivos específicos deste trabalho:

- Realização de ensaios preliminares para estabelecimento de condições experimentais adequadas para a determinação de U utilizando INAA e ENAA com irradiações de curta e longa duração.

- Validação dos procedimentos de INAA e de ENAA por meio da avaliação dos resultados em relação à exatidão, precisão, limite de detecção e das fontes de incerteza envolvidas nos processos de determinação de U.

- Aplicação dos procedimentos estabelecidos de INAA e ENAA na análise de biomonitores de poluição atmosférica.

- Estudo comparativo entre os resultados das determinações da fração mássica de U nas amostras de biomonitores obtidas com INAA e ENAA.

Com o desenvolvimento desta pesquisa, espera-se disponibilizar procedimentos adequados da análise por ativação com nêutrons para a determinação de U em amostras de biomonitores com resultados confiáveis acompanhados de suas incertezas. 


\section{REVISÃo BIBLIOGRÁFICA}

Neste Capítulo é apresentada uma revisão de trabalhos sobre a determinação de U em amostras ambientais, a qual foi feita de modo a demonstrar a evolução da quantificação de U pelo método de NAA em diferentes matrizes de amostras ambientais, desde o início de sua aplicação até os dias de hoje.

As metodologias radioanalíticas se desenvolveram rapidamente a partir da descoberta do nêutron por J. Chadwick em 1932, isso porque apenas quatro anos depois, em 1936, a análise por ativação com nêutrons foi concebida por G. Hevesy e H. Levi. Entretanto, as técnicas nucleares se aperfeiçoaram somente após a construção de reatores nucleares, nos anos de 1940, e do desenvolvimento de detectores de cintilação de baixa resolução na década de 1950 (HAMIDATOU et al., 2013). Foram realizadas, ainda nos anos de 1950, análises de amostras por NAA, em que foram determinadas as frações mássicas de U em amostras de solo e de fosfato, cuja a precisão dos resultados foi de $\pm 10 \%$.

Em 1963, Morgan e Lovering (1963) determinaram U e Th em rochas por NAA e apresentaram uma discussão sobre os radionuclídeos utilizados para a identificação destes elementos e os problemas de interferência que poderiam ocorrer nas análises. Neste trabalho, foi concluído que o método de NAA foi adequado para amostras com frações mássicas de U da ordem de ppm. Outro trabalho semelhante foi publicado por Amiel et al. (1967), onde foi determinado U em meteoritos por INAA e DGNAA. As frações mássicas encontradas foram na faixa de 10 a $30 \mathrm{ng} \mathrm{g}^{-1}$ e a precisão de seus resultados foi de $\pm 10 \%$.

No artigo de Weaver (1974) foi determinado U por NAA em amostras ambientais de diferentes matrizes tais como carvão, fígado bovino, folhas, água do mar e minerais, com o intuito de aprimorar o método. Neste caso, a NAA foi considerada eficaz para quantificar frações mássicas de $\mathrm{U}$ acima de $50 \mathrm{ng} \mathrm{g}^{-1}$ nas amostras analisadas.

Em 1974, Atalla e Lima (1974) realizaram a determinação do U por ENAA em matrizes e minérios de Th, usando separação radioquímica. Foram discutidos diversos parâmetros como a precisão, exatidão, sensibilidade e limite de detecção, que foram avaliados como aceitáveis considerando as baixas frações mássicas de U nas amostras (da ordem de $\mathrm{ppb).} \mathrm{Os} \mathrm{autores} \mathrm{concluíram} \mathrm{que} \mathrm{as} \mathrm{principais} \mathrm{vantagens} \mathrm{do} \mathrm{uso} \mathrm{da} \mathrm{ENAA} \mathrm{consistem} \mathrm{na}$ diminuição da atividade da amostra e na melhor resolução dos picos no espectro, além da redução da interferência causada pelo ${ }^{233} \mathrm{Th},{ }^{153} \mathrm{Sm}$ e ${ }^{155} \mathrm{Sm}$ na determinação do ${ }^{239} \mathrm{U}$.

Posteriormente, após anos de aplicação da NAA na determinação de diferentes elementos em amostras dos mais diversos tipos de matrizes, no trabalho de Heydorn (1995), foi apresentada uma validação do método de NAA, por meio da análise de materiais de referência certificados de matrizes distintas. A principal conclusão deste trabalho foi a ausência de vieses 
significativos na técnica e a possibilidade de comprovar sua rastreabilidade.

Em 2002, Acharya et al. (2002) apresentaram a validação do método k0 de NAA (k0-INAA). Essa validação foi realizada pela análise de diversos tipos de materiais de referência certificados para diferentes elementos e pela quantificação da incerteza de medição. Foi concluído que a técnica k0-INAA permite obter resultados compatíveis aos obtidos pelo tradicional método comparativo de NAA.

No trabalho de Rosamilia et al. (2004), foi feita determinação de U por NAA em amostras de liquens e cascas de árvores coletadas na região da Bósnia-Herzegovina. A proposta consistia em avaliar a contaminação do ar consequente do uso de U empobrecido como munição durante a guerra da Bósnia na década de 1990. Os autores concluíram que as amostras funcionaram como bioacumuladores efetivos de poluição atmosférica e que oito anos após o término do conflito, ainda foi encontrada, naquela região, contaminação por U empobrecido. No mesmo ano, no trabalho de EI-Taher et al. (2004) foi demonstrada a viabilidade do uso do método de NAA na determinação de U em amostras ambientais coletadas no Egito.

Foi realizada uma revisão sobre o estudo de amostras ambientais pelo método NAA no artigo de Witkowska et al. (2005). Os autores mencionaram que há uma diminuição no uso da NAA em comparação a técnicas não radiométricas como o ICP-MS na análise de amostras biológicas. Entretanto, os autores concluíram que a NAA apresenta vantagens em relação às técnicas citadas no estudo de amostras de difícil dissolução e com baixas frações mássicas de analito. Outros pontos fortes da NAA são o mínimo preparo da amostra exigido para a análise e a alta precisão de seus resultados.

No artigo de Shtangeeva (2010) foram discutidas as diferenças na absorção de U e de Th entre plantas nativas e cultivadas em uma região que não apresenta histórico de contaminação destes elementos. As frações mássicas foram determinadas usando NAA e seus resultados permitiram concluir que plantas que cresceram em solos ricos nos radionuclídeos de U e Th apresentam altas frações mássicas desses elementos em suas raízes. Além disso, foi verificado que o Th está menos disponível do que o U para a captação pelas plantas.

Em 2013, Landsberger e Kapsimalis (2013) determinaram U em amostras ambientais e geológicas usando as técnicas de INAA e ENAA pela medida dos radionuclídeos ${ }^{239} \mathrm{U}$ $\mathrm{e}^{239} \mathrm{~Np}$. Os seus resultados demonstraram que a técnica mais adequada a esta determinação foi a ENAA. Os autores também chamaram a atenção sobre a interferência causada por altas frações mássicas de $\mathrm{Mn}, \mathrm{Cl}$ e $\mathrm{Na}$ nas amostras, que pode comprometer a qualidade dos resultados. Isto é, as altas atividades de ${ }^{56} \mathrm{Mn},{ }^{38} \mathrm{Cl} \mathrm{e}{ }^{24} \mathrm{Na}$ interferem na medida do ${ }^{239} \mathrm{U}$.

O artigo de Rodríguez et al. (2015) consistiu no estudo da determinação de U em amostras ambientais usando a técnica de microextração líquido-líquido automatizada associada a espectrofotometria (LLME). A principal vantagem deste método foi a possibilidade de realizar análises em diversos tipos de amostras. A técnica foi testada em diferentes matrizes 
ambientais e validada utilizando materiais de referência certificados. Os resultados permitiram comprovar a eficácia do método proposto.

No trabalho de Märten et al. (2015), foi apresentada uma reconstituição do histórico de contaminação de uma área afetada por 40 anos do processo de mineração de U, avaliado por meio da técnica de dendroanálise (i.e. determinação de elementos presentes nos anéis de crescimento das árvores). A determinação de U nos anéis de crescimento foi feita por ICP-MS. Os resultados mostraram que três, de cada quatro árvores de carvalho (Quercus $s p$.) analisadas, apresentaram frações mássicas de U semelhantes e aproximadamente duas ordens de grandeza mais altas que a do período anterior a mineração.

Em 2016, El-Taher e Khater (2016) avaliaram a composição de minérios fosfatados encontrados na cidade de Hazm El-Jalamid, no nordeste da Arábia Saudita. Foram determinadas as frações mássicas de 19 elementos diferentes, além de U, utilizando os métodos de NAA e ICP-MS. Seus resultados foram comparados com valores encontrados em outras localidades do mundo e na maioria dos casos, as frações mássicas determinadas em El-Jalamid foram menores que as apresentadas na literatura.

Alsabbagh et al. (2016) quantificaram U em rochas de carbonato da Jordânia por três diferentes métodos, sendo eles: NAA, espectrometria de raios gama e ICP-MS. Os autores concluíram que as frações mássicas médias de U determinadas pelos diferentes métodos foram semelhantes, o que indica aplicabilidade das técnicas para análise deste elemento nesse tipo de matriz.

No trabalho de Landsberger et al. (2017b) foi investigado o desequilíbrio nas séries do U e do actínio (Ac) em amostras oriundas da exploração de petróleo. Esta investigação foi motivada pelas altas taxas de radiação detectadas em tubulações usadas em campos de exploração de petróleo. Foi utilizado o método NAA para a determinação do ${ }^{238} \mathrm{U}$ e do ${ }^{232} \mathrm{Th}$. Por fim, os autores determinaram o desequilíbrio nas séries do U e do Th decorrente das altas quantidades de ${ }^{226} \mathrm{Ra}$ e ${ }^{228} \mathrm{Ra}$.

Foi realizado, no artigo de Bártová et al. (2017), um estudo da relação existente entre as frações mássicas de radônio no ar e dos radionuclídeos presentes em materiais de construção, como tijolos de cerâmica e blocos de concreto. A justificativa desse trabalho foi verificar se podem existir efeitos da radiação provenientes de materiais de construção na população. Estes efeitos seriam causados pela radiação alfa emitida pelo radônio. Para esta dosimetria, foram medidos ${ }^{40} \mathrm{~K}$ e os membros das cadeias radioativas naturais do ${ }^{238} \mathrm{U}$ e do ${ }^{232} \mathrm{Th}$. As técnicas utilizadas para a determinação dos radionuclídeos mencionados foram a XRF, a espectroscopia de raios gama e a NAA. Foi verificado que a NAA proporcionou a obtenção de resultados precisos e exatos para os três elementos analisados e a espectrometria gama exige maior preparação das amostras e cuidados específicos na contagem.

No artigo de Asim et al. (2017) foram desenvolvidas metodologias para a análise do minério de U (pechblenda) por NAA e ICP-OES. Os elementos traços foram quantificados 
por NAA e os elementos com maiores frações mássicas por ICP-OES, o que resultou na determinação de 46 elementos em amostras de pechblenda fornecidas pela Agência Internacional de Energia Atômica (IAEA). Dessa maneira, ficou demonstrada a eficiência de ambas as técnicas para a determinação de elementos em diferentes intervalos de frações mássicas.

Landsberger et al. (2017a) caracterizaram amostras de resíduos de bauxita ("red mug") advindos de instalações industriais a fim de avaliar os riscos radiológicos que este material pode causar à saúde de indivíduos que trabalham naquele local. Esses riscos estariam relacionados às altas taxas de dose por absorção em diferentes partes do organismo exposto. Foram avaliadas as frações mássicas dos radionuclídeos ${ }^{235} \mathrm{U},{ }^{238} \mathrm{U},{ }^{232} \mathrm{Th}$ e ${ }^{40} \mathrm{~K}$ por meio de INAA e ENAA. O intuito deste trabalho foi obter resultados confiáveis para que, no futuro, possam ser realizadas abordagens semelhantes na análise de resíduos que ofereçam risco radiológico a seres humanos. Foi demonstrada a aplicabilidade da NAA na determinação de $\mathrm{U}$, Th e K em diferentes frações mássicas devido, principalmente, à alta sensibilidade da técnica.

No artigo de Campoy-Diaz et al. (2018) foi estudada a possibilidade de utilizar tecidos de animais como bioindicadores de poluição, avaliando a capacidade do molusco Pomacea canaliculata bioconcentrar $\mathrm{Hg}$, As e $\mathrm{U}$ em diferentes partes de seu organismo. As frações mássicas destes elementos foram determinadas por NAA e os seus resultados permitiram aos autores concluir que esse molusco pode ser considerado um bioindicador da poluição aquática devido à sua capacidade de acumular elementos químicos em seu organismo.

O trabalho de Byers et al. (2018) é um exemplo de pesquisa que procura ampliar a sustentabilidade da energia nuclear a longo prazo por meio da extração de $U$ dos oceanos para a produção de combustíveis nucleares. O objetivo deste trabalho foi avaliar o desenvolvimento de materiais adsorventes para a retenção do U existente na água do mar. As frações mássicas de $U$ foram quantificadas por INAA e ENAA, que foram considerados adequados para avaliar a composição do adsorvente antes e depois da exposição. A principal contribuição deste trabalho foi o desenvolvimento de uma metodologia que permitirá reduzir os custos da recuperação do U presente nos oceanos.

Conforme mostra o levantamento bibliográfico realizado neste Capítulo, o processo de determinação de $\mathrm{U}$ em amostras ambientais continua sendo um assunto de grande importância científica abordado em diversos trabalhos na literatura. 


\section{FUNDAMENTOS TEÓRICOS DA ANÁLISE POR ATIVAÇÃo COM NÊU- TRONS}

No presente Capítulo, são apresentados os fundamentos da análise por ativação com nêutrons (NAA). Inicialmente são descritos os aspectos históricos da NAA desde sua descoberta, passando pelo seu desenvolvimento, até se tornar a técnica analítica utilizada nos dias atuais. Em seguida, são apresentados os princípios do método, os tipos de nêutrons, classificados por faixas de energia, a integral de ressonância e a seção de choque. Por fim, são feitas as deduções para a obtenção da equação usada no cálculo da fração mássica do elemento de interesse na amostra analisada.

\subsection{História do desenvolvimento da análise por ativação com nêutrons}

Após a descoberta do nêutron por Chadwick em 1932 e da radioatividade induzida por Frédéric e Irène Joliot em 1934, Enrico Fermi e George de Hevesy realizaram experimentos utilizando nêutrons para produzir radionuclídeos artificiais, com o intuito de estudar os elementos terras raras. Os resultados obtidos em 1935, sobre a interação dos nêutrons com tais elementos, marcaram o surgimento da análise por ativação com nêutrons (GREENBERG et al., 2011).

Hevesy e Hilde Levi usaram uma fonte de nêutrons e um detector de radiação que consistia em uma câmara de ionização. A amostra analisada continha disprósio (Dy), que foi identificado por se tornar altamente radioativo após a irradiação com nêutrons. Essas pesquisas mostraram que a reação nuclear poderia ser usada para determinar elementos presentes nas amostras pela medida da radioatividade induzida (HAMIDATOU et al., 2013; GREENBERG et al., 2011).

Em 1949, a aplicação da NAA foi associada a um reator nuclear, como fonte de nêutrons, no lugar das antigas fontes isotópicas. O uso de reatores nucleares permitiu obter atividades específicas mais altas que as atingidas com as antigas fontes de nêutrons. Dessa maneira, a técnica se beneficiou com o advento dos reatores nucleares. Nessa mesma época foram estudados os erros de medida da radioatividade e problemas como a autoabsorção e a geometria de contagem (HAMIDATOU et al., 2013; GREENBERG et al., 2011).

Entre os anos de 1950 a 1960, a NAA se desenvolveu com os estudos do decaimento radioativo, das características de absorção da radiação e das separações radioquímicas. A espectrometria gama com detectores de cintilação de baixa resolução $(\mathrm{NaI}(\mathrm{Tl}))$ foi de grande importância para as análises iniciais dos radionuclídeos. A separação radioquímica de uma mistura de radioisótopos era necessária, naquela época, para a determinação seletiva dos elementos de interesse (HAMIDATOU et al., 2013; GREENBERG et al., 2011).

O uso da espectrometria gama com detectores semicondutores de Ge, Si, etc., no 
início dos anos 60, aumentou significativamente a seletividade da NAA. Isso possibilitou que radionuclídeos pudessem ser identificados individualmente em uma mistura de elementos, sem a necessidade de realizar separação radioquímica e, como consequência direta, surgiu a análise por ativação com nêutrons instrumental (INAA). O uso dos analisadores de pulso multicanais, dos computadores e dos softwares laboratoriais para processamento de dados estendeu a aplicação da técnica para o estudo de amostras complexas de diferentes matrizes (HAMIDATOU et al., 2013; GREENBERG et al., 2011).

A INAA pode ser aplicada em vários campos da ciência e isso se deve às características favoráveis da metodologia em relação a outras, como a mínima preparação da amostra exigida para a análise e por ser uma técnica não destrutiva. Devido à NAA estar relacionada com as propriedades do núcleo atômico, suas análises não dependem do estado físico ou químico dos elementos. Outra particularidade da técnica reside no fato de que elementos como $\mathrm{H}, \mathrm{C}, \mathrm{N}$ e $\mathrm{O}$, que tem números atômicos baixos e são os principais componentes da maioria dos tipos de matrizes, não se ativam pela irradiação com nêutrons. Logo, eles não interferem na determinação das atividades dos elementos de interesse. A técnica apresenta grande sensibilidade, seus resultados têm boa exatidão e precisão, além da alta seletividade da espectrometria gama, que permite uma determinação multielementar (HAMIDATOU et al., 2013).

Entretanto, a INAA tem como limitação o seu alto custo, considerando que a técnica exige elevado fluxo de nêutrons para a ativação dos elementos, o que torna necessário um reator nuclear para sua realização. Além disso, nem todos elementos químicos podem ser determinados pelo método, dependendo das características nucleares do isótopo alvo (GREENBERG et al., 2011).

No Instituto de Pesquisas Nucleares e Energéticas, o IPEN, a NAA pôde ser realizada com a implementação do reator de pesquisas IEA-R1 em 1957. Esse reator de pesquisa tem a NAA como uma de suas mais importantes aplicações desde sua inauguração (VASCONCELLOS et al., 2004).

\subsection{Princípio do método de análise por ativação com nêutrons}

A NAA é baseada em processos nucleares que, usados para fins analíticos, resultam na determinação das frações mássicas de elementos em diferentes matrizes. Nessa metodologia, os elementos que compõem a amostra, quando irradiados com nêutrons, tornamse excitados e emitem radiação gama. Isto é, a irradiação com nêutrons converte núcleos estáveis, a priori, em radionuclídeos e estes por sua vez, emitem radiações que podem ser usadas para identificação e quantificação dos elementos que compõem a amostra. Cerca de $70 \%$ dos elementos químicos da tabela periódica apresentam características adequadas para determinação por NAA. Na Figura 1, se encontra uma tabela periódica com informações sobre a determinação dos elementos por NAA. 
Figura 1 - Tabela periódica com informações sobre os elementos que podem ser determinados pela INAA.

\begin{tabular}{|c|c|c|c|c|c|c|c|c|c|c|c|c|c|c|c|c|c|}
\hline $\begin{array}{c}1 \\
\mathbf{H}\end{array}$ & & & & & & & & & & & & & & & & & $\begin{array}{c}2 \\
\mathrm{He}\end{array}$ \\
\hline 3 & 4 & & & & & & & & & & & 5 & 6 & 7 & 8 & 9 & 10 \\
\hline $\mathbf{L i}$ & Be & & & & & & & & & & & B & $\mathbf{C}$ & $\mathbf{N}$ & O & $\mathbf{F}$ & $\mathrm{Ne}$ \\
\hline 11 & 12 & & & & & & & & & & & 13 & 14 & 15 & 16 & 17 & 18 \\
\hline Na & $\mathrm{Mg}$ & & & & & & & & & & & Al & Si & $\mathbf{P}$ & $\mathbf{S}$ & Cl & Ar \\
\hline 19 & 20 & 21 & 22 & 23 & 24 & 25 & 26 & 27 & 28 & 29 & 30 & 31 & 32 & 33 & 34 & 35 & 36 \\
\hline $\mathbf{K}$ & Ca & Sc & $\mathbf{T i}$ & $\mathbf{V}$ & $\mathrm{Cr}$ & Mn & $\mathbf{F e}$ & Co & $\mathrm{Ni}$ & $\mathbf{C u}$ & $\mathbf{Z n}$ & $\mathbf{G a}$ & Ge & As & Se & $\mathrm{Br}$ & $\mathbf{K r}$ \\
\hline 37 & 38 & 39 & 40 & 41 & 42 & 43 & 44 & 45 & 46 & 47 & 48 & 49 & 50 & 51 & 52 & 53 & 54 \\
\hline $\mathbf{R b}$ & $\mathrm{Sr}$ & $\mathbf{Y}$ & $\mathbf{Z r}$ & $\mathbf{N b}$ & Мo & Tc & $\mathbf{R u}$ & $\mathbf{R h}$ & Pd & Ag & Cd & In & Sn & Sb & Te & I & Xe \\
\hline 55 & 56 & 57 & 72 & 73 & 74 & 75 & 76 & 77 & 78 & 79 & 80 & 81 & 82 & 83 & 84 & 85 & 86 \\
\hline Cs & Ba & ${ }^{1} \mathrm{La}$ & Hf & $\mathbf{T a}$ & $\mathbf{W}$ & $\mathbf{R e}$ & Os & Ir & $\mathbf{P t}$ & Au & Hg & Tl & $\mathbf{P b}$ & $\mathbf{B i}$ & Po & At & $\mathbf{R n}$ \\
\hline 87 & 88 & 89 & 104 & 105 & & & & & & & & & & & & & \\
\hline $\mathrm{Fr}$ & $\mathbf{R a}$ & ${ }^{2} \mathrm{Ac}$ & Rf & Db & & & & & & & & & & & & & \\
\hline
\end{tabular}

\begin{tabular}{|c|c|c|c|c|c|c|c|c|c|c|c|c|c|c|}
\hline \multirow{2}{*}{ Lantanídeos } & 58 & 59 & 60 & 61 & 62 & 63 & 64 & 65 & 66 & 67 & 68 & 69 & 70 & 71 \\
& $\mathbf{C e}$ & $\mathbf{P r}$ & $\mathbf{N d}$ & $\mathbf{P m}$ & $\mathbf{S m}$ & $\mathbf{E u}$ & $\mathbf{G d}$ & $\mathbf{T b}$ & $\mathbf{D y}$ & $\mathbf{H o}$ & $\mathbf{E r}$ & $\mathbf{T m}$ & $\mathbf{Y b}$ & $\mathbf{L u}$ \\
\hline \multirow{2}{*}{ Actinídeos } & 90 & 91 & 92 & 93 & 94 & 95 & 96 & 97 & 98 & 99 & 100 & 101 & 102 & 103 \\
& $\mathbf{T h}$ & $\mathbf{P a}$ & $\mathbf{U}$ & $\mathbf{N p}$ & $\mathbf{P u}$ & $\mathbf{A m}$ & $\mathbf{C m}$ & $\mathbf{B k}$ & $\mathbf{C f}$ & $\mathbf{E s}$ & $\mathbf{F m}$ & $\mathbf{M d}$ & $\mathbf{N o}$ & $\mathbf{L r}$ \\
\hline
\end{tabular}

Não podem ser determinados por INAA

Podem ser determinados com dificuldades por INAA

Elementos normalmente determinados por INAA

Fonte: Adaptado de Eby (2018)

O procedimento de NAA se inicia com a irradiação da amostra no reator, onde ocorre a captura de nêutrons pelo núcleo alvo, i.e., uma colisão inelástica que resultará na criação de um núcleo composto em estado excitado. A energia de excitação é igual a energia de ligação do nêutron com o núcleo. Esse núcleo irá se desexcitar quase que instantaneamente em uma configuração mais estável, em suma, ocorre uma reação $(n, \gamma)$. Nesse processo são emitidos raios gama "prontos" característicos que são medidos e utilizados analiticamente na "Prompt gamma" Neutron Activation Analysis (PGNAA) (HAMIDATOU et al., 2013; GREENBERG et al., 2011). Tal sequência de eventos pode ser descrita pela reação genérica representada pela seguinte expressão:

$$
{ }^{A} X(n, \gamma){ }^{A+1} X
$$

Na maioria dos casos, o núcleo radioativo permanece instável após a emissão dos raios gama "prontos" e inicia uma sequência de decaimentos até chegar à estabilidade. Essas emissões ocorrem pelos processos de decaimento $\alpha, \beta^{-}$, captura eletrônica, $\beta^{+}$e transição interna, além de, na maioria dos casos, serem acompanhados por emissões de radiação $\gamma \mathrm{e}$ raios $X$ (HAMIDATOU et al., 2013; GREENBERG et al., 2011). Os processos de captura neutrônica e de desexcitação do núcleo composto estão apresentados no esquema da Figura 2. 
Figura 2 - Esquema do processo de captura de nêutron pelo núcleo alvo seguido por emissões gama.

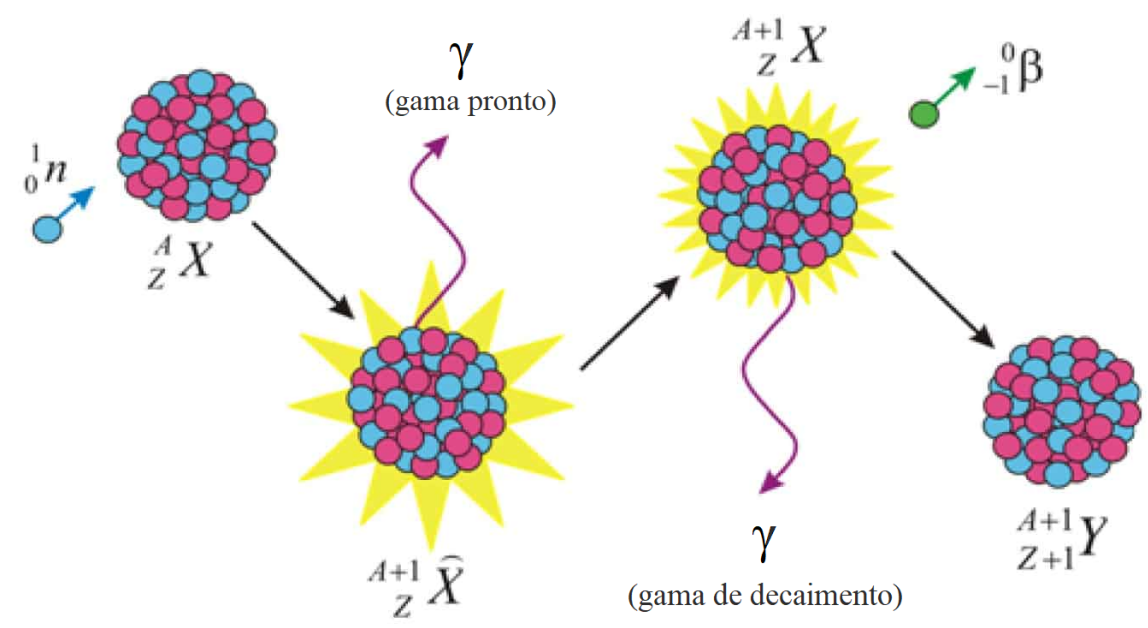

Fonte: Adaptado de Nuclear Power (2018a)

Os radionuclídeos decaem emitindo partículas $\beta^{-}$e radiação gama com valores característicos de energias. Isso permite identificar e quantificar os elementos presentes na amostra. Para isso, as amostras devem ser medidas instrumentalmente por um detector semicondutor de alta resolução logo após a irradiação. Essa medição tem propriedades qualitativas como o valor da energia da radiação gama característica $\left(E_{\gamma}\right)$ e da meia-vida do radionuclídeo e quantitativa como a intensidade da radiação $\left(I_{\gamma}\right)$, que é o número de vezes que a energia da radiação gama característica de um determinado radionuclídeo é medida por unidade de tempo. A sequência de emissões de um núcleo radioativo é, normalmente, representada por um esquema de decaimento, como o presente na Figura 3 para o ${ }^{239} \mathrm{~Np}$. Neste caso, ocorre uma captura de nêutron pelo nuclídeo ${ }^{238} \mathrm{U}$ que forma um radionuclídeo ${ }^{239} \mathrm{~Np}$ com meia-vida de 2,356 dias. Em sequência, ocorrerá uma série de emissões, descritas no esquema, até o radionuclídeo decair para o ${ }^{239} \mathrm{Pu}$, cuja meia-vida é de 24110 anos. 
Figura 3 - Esquema de decaimento do ${ }^{239} \mathrm{~Np}$.

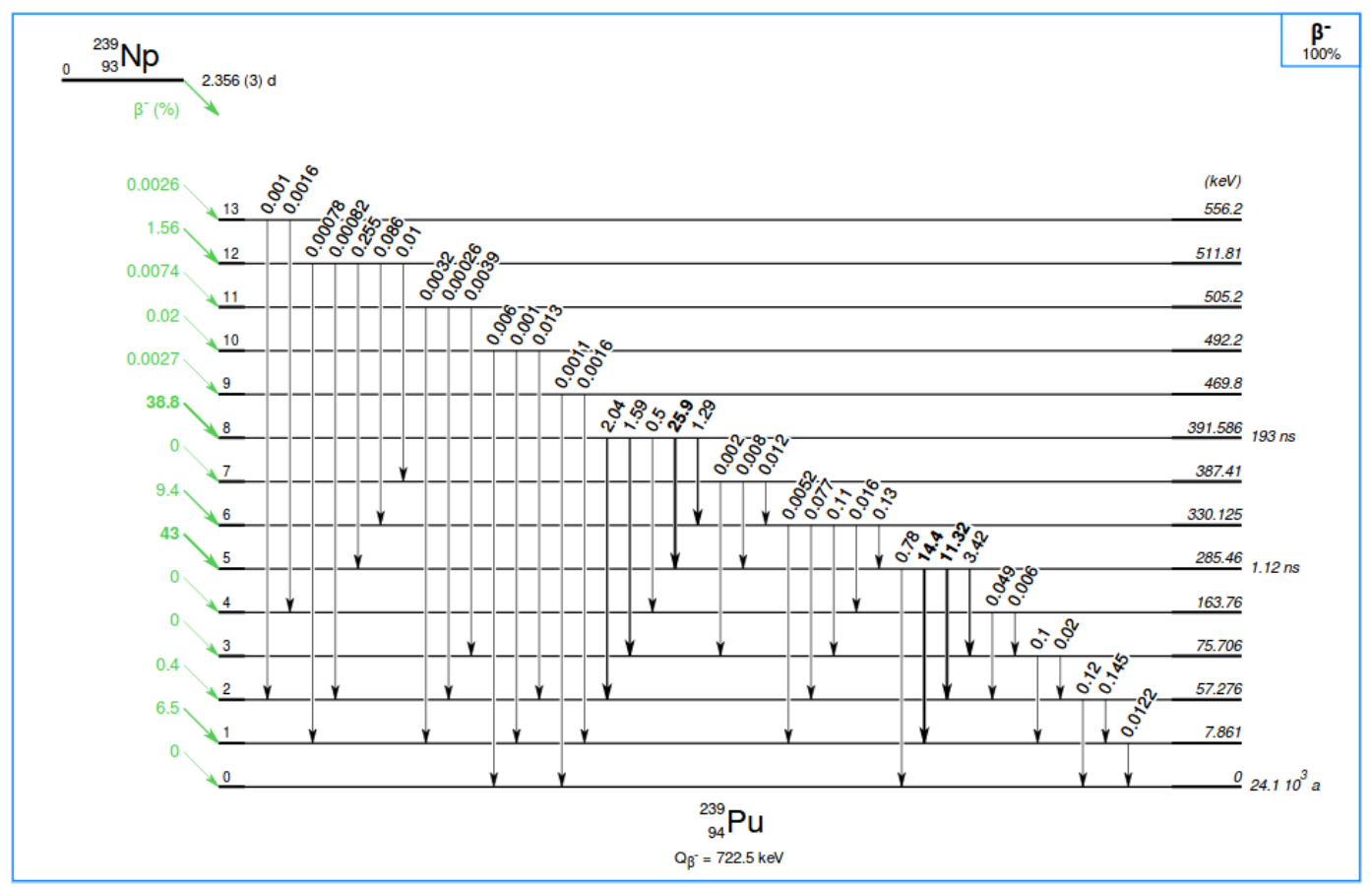

Fonte: Nucleide - Lara (2018)

A probabilidade de um nêutron interagir com o núcleo varia em função da energia do nêutron incidente. A seção de choque $(\sigma)$ é uma medida da probabilidade de que a reação de captura se realize. Ela depende de diferentes tipos de reações, elementos e distribuição de energia dos nêutrons bombardeados. Então, para cada núcleo atômico existe uma relação própria entre a energia do nêutron e o valor da seção de choque de captura.

Em reatores de pesquisa, que são fontes intensas de nêutrons, três tipos de nêutrons podem ser produzidos, a saber:

- Nêutrons rápidos ou de fissão: São liberados na fissão do ${ }^{235} \mathrm{U}$ e o intervalo da sua distribuição de energia é de $100 \mathrm{keV}$ a $25 \mathrm{MeV}$. O moderador do reator (água) tem como função, entre outras, desacelerar esses nêutrons para aumentar a probabilidade de eles gerarem uma reação em cadeia de fissão do ${ }^{235} \mathrm{U}$.

- Nêutrons epitérmicos: São nêutrons no processo de desaceleração por interação com as moléculas de água do moderador e apresentam energias entre 0,5 eV e $100 \mathrm{keV}$.

- Nêutrons térmicos: São nêutrons em equilíbrio térmico com os átomos do moderador. Sua distribuição de energia é Maxwelliana e sua energia média é de $0,025 \mathrm{eV}$ e a velocidade mais provável é de $2200 \mathrm{~m} \mathrm{~s}^{-1}$. 
Na Figura 4, está apresentado o esquema da variação do fluxo relativo de nêutrons de um reator nuclear em função da energia.

Figura 4 - Representação esquemática do espectro da taxa de fluência de nêutrons em um reator nuclear.

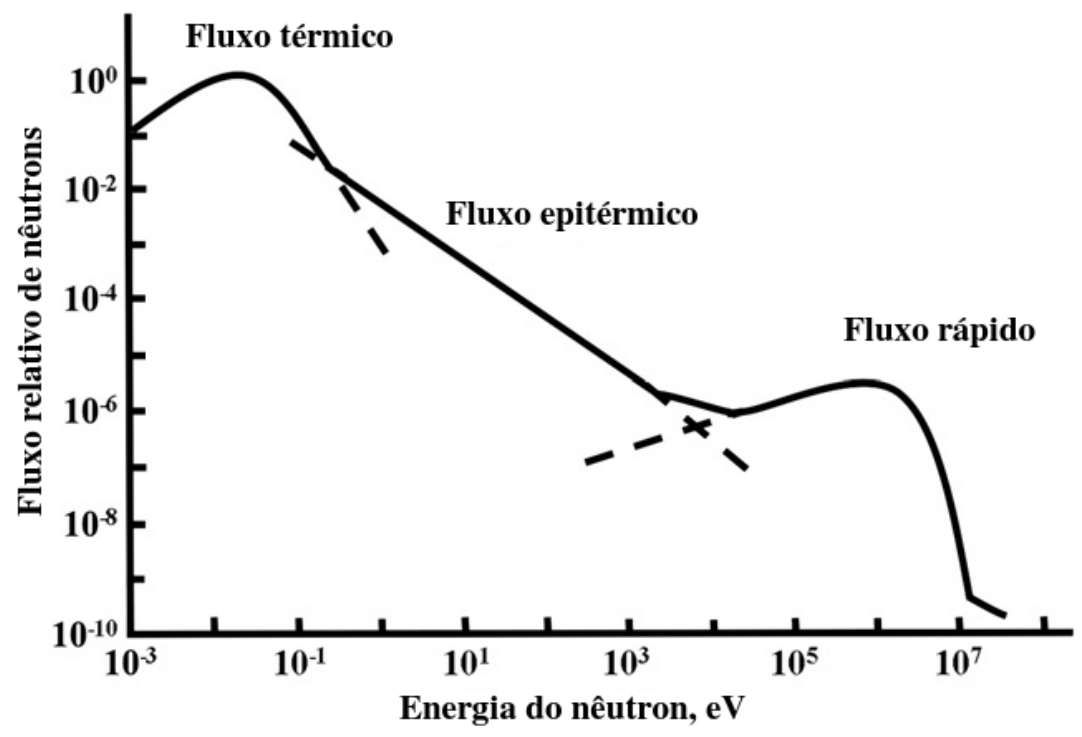

Fonte: Adaptado de Greenberg et al. (2011)

Para a maioria dos nuclídeos, a seção de choque de captura é maior para nêutrons com baixas energias (nêutrons térmicos), entretanto alguns elementos apresentam altas seções de choque para nêutrons com energias mais altas (nêutrons epitérmicos). Na NAA, a reação mais comum é a de captura $(n, \gamma)$, mas também ocorrem as reações $(n, p),(n, \alpha),\left(n, n^{\prime}\right)$ e $(n, 2 n)$, além da reação de fissão $(n, f)$ que ocorre quando o nuclídeo é físsil por captura de nêutrons.

\subsubsection{Integral de ressonância}

Ao se realizar o processo de ativação neutrônica é interessante saber qual tipo de nêutron é o mais indicado para ativar o núcleo de determinado elemento. Considerando a reação nuclear $\mathrm{A}(\mathrm{n}, \gamma) \mathrm{B}$, a taxa de reação $(R)$ da produção do radionuclídeo $\mathrm{B}$ é dada por:

$$
R=\int_{0}^{\infty} \eta(v) v \sigma(v) d v
$$

sendo $v$ a velocidade do nêutron, em $m s^{-1}, \sigma(v)$ a seção de choque, em $m^{2}$ e $\eta(v) d v$ a densidade neutrônica, em $\mathrm{m}^{-3}$. A taxa de reação pode ser calculada dividindo a integral em duas regiões do espectro de energia do nêutron, a região térmica e epitérmica (equação 3). A 
divisão é realizada no limite inferior de energia do fluxo epitérmico, conhecido como energia de corte do cádmio $\left(E_{C d}=0,55 \mathrm{eV}\right)$, cujo valor da velocidade correspondente é dado por $v_{C d}$.

$$
R=\int_{0}^{v_{C d}} \eta(v) v \sigma(v) d v+\int_{v_{C d}}^{\infty} \eta(v) v \sigma(v) d v
$$

A primeira integral resulta em:

$$
\int_{0}^{v_{C d}} \eta(v) v \sigma(v) d v=v_{0} \sigma_{0} \int_{0}^{v_{C d}} \eta(v) d v=\eta v_{0} \sigma_{0}
$$

onde $\eta=\int_{0}^{v_{C d}} \eta(v) d v$ é chamada de densidade térmica do nêutron e $\Phi_{t h}=\eta v_{0}$, sendo $\Phi_{t h}$ a taxa de fluência convencional para nêutrons térmicos, em $m^{-2} s^{-1}, \sigma_{0}$ é a seção de choque para nêutrons térmicos, em $\mathrm{m}^{2}$, à $0,025 \mathrm{eV}$ e $v_{0}$ é a energia mais provável do nêutron a $20^{\circ} \mathrm{C}$ $\left(v_{0}=2200 \mathrm{~m} \mathrm{~s}^{-1}\right)$.

Para calcular a integral na região epitérmica, torna-se conveniente realizar uma troca de variáveis para que a integral fique em função da energia do nêutron $\left(E_{n}\right)$, como na equação 5 .

$$
\int_{V_{C d}}^{\infty} \eta(v) v \sigma(v) d v=\Phi_{e p i} \int_{E_{C d}}^{E_{\max }} \frac{\sigma\left(E_{n}\right)}{E_{n}} d E_{n}=\Phi_{e p i} I_{0}
$$

sendo $\Phi_{e p i}$ a taxa de fluência convencional para nêutrons epitérmicos e $I_{0}$ a integral de ressonância, definida como:

$$
I_{0}=\int_{E_{C d}}^{E_{\max }} \frac{\sigma\left(E_{n}\right)}{E_{n}} d E_{n}
$$

A integral de ressonância é definida como a seção de choque microscópica média considerando que a relação da energia com a taxa de fluência para nêutrons epitérmicos é proporcional a $E_{n}^{-1}$. Essa aproximação é adequada para grande maioria das reações $(n, \gamma)$ (GREENBERG et al., 2011; MAIDANA, 2000).

O valor da integral de ressonância para os nuclídeos que seguem a lei $v^{-1}$ é aproximadamente igual a zero. Decorre disso que a contribuição dos nêutrons epitérmicos para a ativação desses nuclídeos é baixa. Entretanto, em casos que o nuclídeo apresenta seção de choque térmica relativamente baixa e integral de ressonância alta, a maior parte da ativação será realizada por nêutrons epitérmicos (ATALLA, 1973).

A integral de ressonância de um nuclídeo é determinada experimentalmente irradiando o material no espectro do reator (MAIDANA, 2000). Na Tabela 1, pode-se observar valores da integral de ressonância para alguns elementos. 
Tabela 1 - Valores de seção de choque e integral de ressonância de isótopos estáveis e elementos

\begin{tabular}{cccc}
\hline Isótopo & $\begin{array}{r}\text { Abundância } \\
\text { Isotópica, } \%\end{array}$ & $\begin{array}{c}\text { Seção de choque de } \\
\text { captura “ } \sigma \text { ", b }\end{array}$ & $\begin{array}{c}\text { Integral de } \\
\text { ressonância “ } I_{0} \text { ", b }\end{array}$ \\
\hline${ }^{12} \mathrm{C}$ & 98,892 & $(3,53 \pm 0,05) \cdot 10^{-3}$ & $(1,57 \pm 0,05) \cdot 10^{-3}$ \\
${ }^{14} \mathrm{~N}$ & 99,6337 & $(79,8 \pm 1,4) \cdot 10^{-3}$ & $(34 \pm 1) \cdot 10^{-3}$ \\
${ }^{16} \mathrm{O}$ & 99,7628 & $(0,190 \pm 0,019) \cdot 10^{-3}$ & $0,085 \cdot 10^{-3}$ \\
${ }^{23} \mathrm{Na}$ & 100 & $0,530 \pm 0,005$ & $0,311 \pm 0,010$ \\
${ }^{27} \mathrm{Al}$ & 100 & $(231 \pm 3) \cdot 10^{-3}$ & $0,14 \pm 0,01$ \\
${ }^{35} \mathrm{Cl}$ & 75,771 & $43,55 \pm 0,40$ & $18 \pm 2$ \\
${ }^{55} \mathrm{Mn}$ & 100 & $13,36 \pm 0,05$ & $14,0 \pm 0,3$ \\
${ }^{79} \mathrm{Br}$ & 50,686 & $10,32 \pm 0,13$ & $127 \pm 14$ \\
${ }^{80} \mathrm{Se}$ & 49,607 & $0,61 \pm 0,05$ & $1,6 \pm 0,2$ \\
${ }^{152} \mathrm{Sm}$ & 26,6 & $206 \pm 6$ & $2970 \pm 100$ \\
${ }^{208} \mathrm{~Pb}$ & 52,3481 & $(0,230 \pm 0,030) \cdot 10^{-3}$ & $0,0020 \pm 0,0002$ \\
${ }^{232} \mathrm{Th}$ & - & $7,35 \pm 0,03$ & $85 \pm 3$ \\
${ }^{238} \mathrm{U}$ & - & $2,680 \pm 0,019$ & $277 \pm 3$ \\
\hline
\end{tabular}

Fonte: IAEA (2003)

Ainda que a parcela do fluxo correspondente aos nêutrons epitérmicos seja menor que a de nêutrons térmicos, a irradiação epitérmica apresenta vantagens na determinação de elementos que possuem valores de integral de ressonância maiores que as secções de choque para nêutrons térmicos, como o U e elementos de terras raras.

\subsection{Equação fundamental da análise por ativação com nêutrons}

No processo de irradiação, a amostra é submetida a um fluxo de nêutrons e os átomos que a compõem possuem determinada probabilidade de interagir com os nêutrons incidentes. O número de núcleos ativados $N\left(t_{i}, t_{d}\right)$ no início da medição, de acordo com Greenberg et al. (2011), é dado por:

$$
N\left(t_{i}, t_{d}\right)=\frac{\phi \sigma N_{0}}{\lambda}\left(1-e^{-\lambda t_{i}}\right) e^{-\lambda t_{d}},
$$

sendo $\phi$ o fluxo de nêutrons, em $n \mathrm{~cm}^{-2} \mathrm{~s}^{-1}, \sigma$ a seção de choque para ativação com nêutrons, em $\mathrm{b}\left(\mathrm{m}^{2}\right), N_{0}$ o número de núcleos alvos, $\lambda$ a constante de decaimento, em $s^{-1}, t_{i}$ o tempo de 
irradiação em $s$ e $t_{d}$ o tempo de decaimento, i.e., tempo entre o fim da irradiação e o começo da medição, em $s$. Contudo, durante o período de medição, o número dos núcleos ativados irá variar devido ao processo de decaimento radioativo. Levando isso em consideração, o número dos núcleos que decaem durante a medição é igual a:

$$
\Delta N=\frac{\phi \sigma N_{0}}{\lambda}\left(1-e^{-\lambda t_{i}}\right) e^{-\lambda t_{d}}\left(1-e^{-\lambda t_{m}}\right)
$$

onde $t_{m}$ é o tempo de medição. Aplicando a relação $N_{0}=\frac{N_{a v} m \theta}{M}$, sendo que $N_{a v}$ é o número de Avogadro, $m$ é a massa do elemento na amostra, $M$ é a massa atômica do elemento e $\theta$ é a sua abundância isotópica, obtém-se para $\Delta N$ a expressão 9.

$$
\Delta N=\frac{\phi \sigma N_{a v} m \theta}{\lambda M}\left(1-e^{-\lambda t_{i}}\right) e^{-\lambda t_{d}}\left(1-e^{-\lambda t_{m}}\right)
$$

Além disso, deve-se considerar que para cada decaimento existe uma probabilidade $I_{\gamma}$ de ser emitida radiação gama (intensidade gama) e que o sistema de um detector real tem probabilidade $\varepsilon(E)$ (probabilidade em função da energia do fóton) de detectar essa radiação. Finalmente, a equação para a atividade é dada por:

$$
A=\frac{\phi \sigma N_{a v} m \theta}{\lambda M}\left(1-e^{-\lambda t_{i}}\right) e^{-\lambda t_{d}}\left(1-e^{-\lambda t_{m}}\right) \varepsilon\left(E_{\gamma}\right) I_{\gamma}
$$

Nesta relação $10, A$ representa a área do pico, cujo valor é fornecido pelo equipamento por meio do espectro de aquisição de dados, em contagens por segundo.

Considerando que o intuito da análise é, na maioria das vezes, determinar a fração mássica de um elemento numa amostra, pode-se, por simplicidade, inferir que $m=m_{a} C_{a}$, onde $m$ é a massa do elemento na amostra, $m_{a}$ é massa total da amostra e $C_{a}$ é sua fração mássica. Então, substituindo essa expressão na equação 10 e a rearranjando, chega-se em:

$$
C_{a}=\frac{\lambda M A}{\phi \sigma N_{a v} m_{a} \theta \varepsilon\left(E_{\gamma}\right) I_{\gamma}\left(1-e^{-\lambda t_{i}}\right) e^{-\lambda t_{d}}\left(1-e^{-\lambda t_{m}}\right)} .
$$

A expressão da fração mássica do analito na amostra (equação 11) depende de vários parâmetros físicos, como $\theta, N_{a v}, M, \sigma, I_{\gamma}$ e $\lambda$, cujos valores podem ser obtidos na literatura. Todavia, parâmetros como $\sigma, I_{\gamma}$ e $\lambda$ não são determinados com precisão para algumas reações (n, $\gamma$ ) e para alguns radionuclídeos. Além disso, a rastreabilidade metrológica dos valores das constantes físicas não está definida para todos os radionuclídeos. Outro problema reside no fato de que esses parâmetros são determinados por métodos diferentes e suas incertezas individuais, quando combinadas com a incerteza de medição da fração mássica do elemento, irão resultar em um valor relativamente alto de incerteza padrão combinada associada ao resultado da medida (GREENBERG et al., 2011). 
Para evitar estes problemas é possível irradiar um padrão, com fração mássica conhecida do elemento de interesse $\left(C_{p}\right)$, juntamente com a amostra cuja fração mássica se pretende determinar. Além da irradiação, a amostra e o padrão devem ser medidos no mesmo equipamento utilizando a mesma geometria. Esse procedimento de determinação é chamado de NAA pelo método comparativo e, dessa maneira, a maioria dos parâmetros experimentais pode ser cancelada por meio do cálculo da razão das áreas dos picos da amostra $\left(A_{a}\right)$ e do padrão $\left(A_{p}\right)$. A NAA pelo método comparativo permite obter resultados com alto nível de precisão (GREENBERG et al., 2011).

Isso porque os termos cancelados se referem ao mesmo elemento, fluxo de nêutrons, emissões gama e tempo de irradiação. A atividade da amostra e do padrão pode ser obtida pelo rearranjo da equação 11, como pode ser visto na relação 12. A razão entre as atividades do padrão e da amostra resulta na expressão 13.

$$
\begin{gathered}
A_{a, p}=\frac{C_{a, p} \phi \sigma N_{a v} m_{a, p} \theta \varepsilon\left(E_{\gamma}\right) I_{\gamma}\left(1-e^{-\lambda t_{i}}\right) e^{-\lambda t_{d}}\left(1-e^{-\lambda t_{m}}\right)}{\lambda M}, \\
\frac{A_{a}}{A_{p}}=\frac{C_{a} m_{a}}{C_{p} m_{p}} e^{-\lambda\left(t_{d a}-t_{d p}\right)}
\end{gathered}
$$

onde os índices $a$ e $p$ se referem à amostra e ao padrão, respectivamente, $A$ é a área do pico, $C$ é a fração mássica, $m$ é a massa e $t_{d}$ é o tempo de decaimento.

O termo $C_{p} m_{p}$ se refere a massa do elemento no padrão $\left(m_{e p}\right)$, logo, pode-se reescrever a expressão 13 utilizando a relação $m_{e p}=C_{p} m_{p}$, que resulta na equação 14 para a quantificação fração mássica do elemento de interesse na amostra.

$$
C_{a}=\frac{m_{e p} A_{a}}{m_{a} A_{p}} e^{\lambda\left(t_{d a}-t_{d p}\right)}
$$

\subsection{Determinação de urânio pelo método de análise por ativação com nêutrons}

As propriedades nucleares do U tornam propícia a aplicação da NAA para sua quantificação em amostras de diversas matrizes (ATALLA, 1973). Este elemento pode ser determinado pela medida de dois radionuclídeos diferentes, o ${ }^{239} \mathrm{U}$ e o ${ }^{239} \mathrm{~Np}$ por meio da seguinte reação $(\mathrm{n}, \gamma)$ :

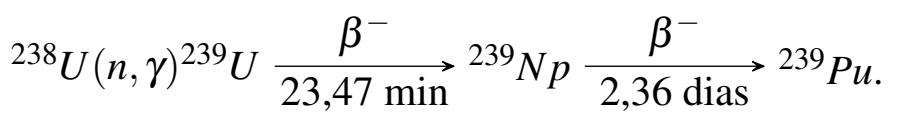

A NAA pode ser aplicada na determinação do U utilizando tanto nêutrons térmicos quanto epitérmicos. 
Isso porque este elemento apresenta valores de seção de choque e de integral de ressonância adequados para ativação com nêutrons em ambas as faixas de energia. Entretanto, a integral de ressonância é consideravelmente maior do que a seção de choque, como pode ser visto na Tabela 1 , o que favorece a ativação por nêutrons epitérmicos.

A seção de choque para nêutrons térmicos é inversamente proporcional à sua velocidade, já para os nêutrons epitérmicos, a seção de choque oscila intensamente para energias discretas. Na região epitérmica, diversos nuclídeos apresentam picos de ressonância, nos quais a seção de choque deixa de variar em função da velocidade do nêutron e passa a apresentar valores relativamente altos de maneira discreta (ATALLA, 1973).

Na Figura 5 é mostrado o gráfico da variação da seção de choque do ${ }^{238} \mathrm{U}$ em relação a energia do nêutron, onde pode-se observar diversos picos de ressonância na região dos nêutrons epitérmicos. Isso indica que o elemento pode ser ativado de maneira mais efetiva utilizando nêutrons epitérmicos. No gráfico da Figura 5 são apresentadas duas curvas onde uma representa a reação de captura e outra de fissão, ambas para ${ }^{238} \mathrm{U}$.

Figura 5 - Gráfico da variação da seção de choque do ${ }^{238} \mathrm{U}$ em função a energia do nêutron incidente para reações $(n, \gamma)$ e $(n, f)$.

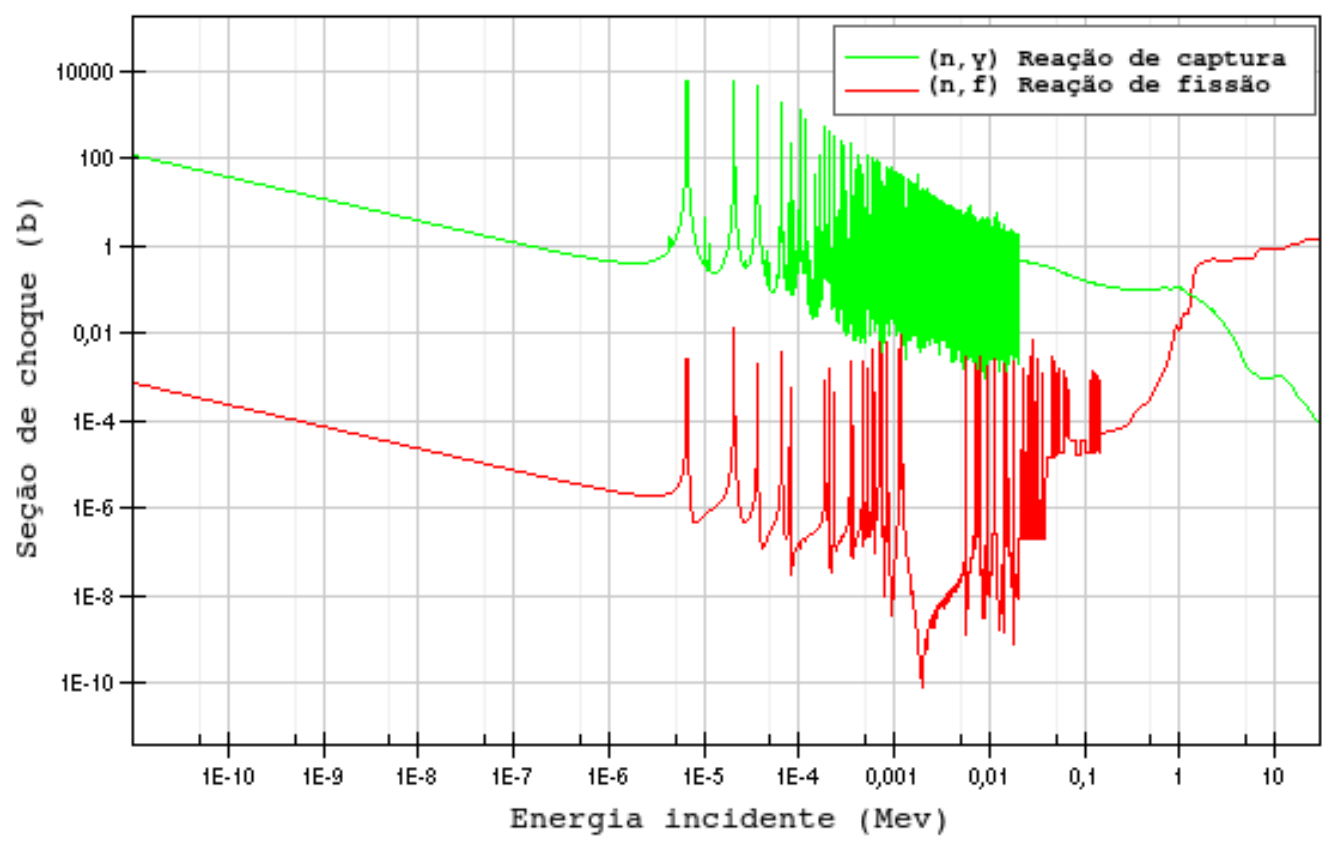

Fonte: Adaptado de Nuclear Power (2018b)

Elementos com números atômicos baixos $(A<30)$, em sua maioria, apresentam valores desprezíveis de picos de ressonância. Em outras palavras, verifica-se que as integrais de ressonância desses elementos são baixas quando comparadas com suas seções de choque, indicando que eles se tornam mais ativos ao serem irradiados com nêutrons térmicos do que com epitérmicos. Em contrapartida, elementos pesados como európio (Eu), samário (Sm), irídio (Ir), tântalo (Ta), tório (Th) e U, que apresentam picos de ressonância acima de 
1000 barns, são ativados mais efetivamente com nêutrons epitérmicos. Disso decorre que nêutrons epitérmicos são mais adequados na ativação de elementos pesados (ATALLA, 1973).

Neste ponto deve ser ressaltada outra vantagem na determinação de U pela análise por ativação com nêutrons epitérmicos (ENAA), que é a redução na atividade de elementos leves como ${ }^{24} \mathrm{Na},{ }^{38} \mathrm{Cl}$ e o ${ }^{56} \mathrm{Mn}$, comumente formados na ativação de amostras de origem biológica.

Em relação a ENAA, convém salientar que a irradiação das amostras pode ser feita no interior de uma cápsula de cádmio $(\mathrm{Cd})$ de espessura adequada para absorver nêutrons de baixa energia. Dessa maneira, a ativação é efetuada apenas por nêutrons não termalizados, cuja energia mínima é igual a energia de corte do $\mathrm{Cd}\left(E_{C d}\right)$.

A análise por ativação com nêutrons epitérmicos não somente facilita a determinação de elementos com alta integral de ressonância como também permite que a atividade da matriz, e das impurezas nela presentes, não predominem no espectro de raios gama e impeçam a quantificação dos elementos de interesse. Isso resulta em um aumento na sensibilidade da técnica para determinação de diversos elementos decorrente da redução da atividade da matriz.

Como desvantagem no uso de ENAA, pode-se citar a diminuição do número de amostras que podem ser irradiadas dentro de uma cápsula e a dose de radiação que o analista poderá ser exposto ao manusear a cápsula de Cd após a irradiação (ATALLA, 1973).

\subsection{Interferências na determinação de elementos em análise por ativação com nêu- trons}

Uma das principais limitações da análise por ativação com nêutrons são as interferências, que podem ser classificadas como: Reações interferentes primárias, interferências decorrentes da fissão de U e interferências espectrais. As reações interferentes primárias acontecem quando um mesmo radioisótopo se forma a partir de dois ou mais núcleos estáveis em reações com nêutrons. Já a interferência devido à fissão do U ocorre quando os radioisótopos determinados por NAA coincidem com os produtos de fissão, alterando os resultados obtidos na análise. As interferências espectrais se dão quando radioisótopos possuem transições gama iguais ou com energias próximas e por conseguinte, o sistema detector não consegue distinguir a origem desses raios gama.

$\mathrm{Na}$ determinação de U pela medida do radionuclídeo ${ }^{239} \mathrm{~Np}$ pode ocorrer a interferência espectral do ${ }^{153} \mathrm{Sm}$. Isso porque o pico de $103,18 \mathrm{keV}$ do ${ }^{153} \mathrm{Sm}$ é próximo ao pico de $106,12 \mathrm{keV}$ do ${ }^{239} \mathrm{~Np}$, o que prejudica a resolução do mesmo pelo sistema detector. O Sm é um elemento formado pela fissão do ${ }^{235} \mathrm{U}$ e possui tempo de meia-vida semelhante ao do $\mathrm{Np}$, o que impossibilita o uso de tempos de decaimento diferentes para evitar o problema de interferência. 


\section{MATERIAIS E MÉTODOS}

\subsection{Materiais}

\subsubsection{Materiais de referência certificados}

A análise de materiais de referência certificados (MRCs) possibilita a realização de um controle de qualidade dos resultados obtidos usando um procedimento analítico estabelecido. Esse controle de qualidade permite avaliar o grau de precisão e de exatidão dos resultados, além de assegurar sua rastreabilidade metrológica, que são fatores fundamentais para a validação de uma metodologia. Os materiais de referência apresentam homogeneidade e estabilidade adequadas em relação às propriedades especificadas. Nos certificados dos MRCs são apresentados valores nominais associados à determinadas características analisadas por procedimentos metrologicamente válidos (INMETRO, 2012).

Neste trabalho foram analisados $11 \mathrm{MRCs}$ de diversos tipos de matrizes com valores certificados ou informativos para as frações mássicas de U. Estes materiais foram produzidos pelos Institute of Nuclear Chemistry and Technology, Polônia (INCT), National Institute of Standards and Technology, EUA (NIST), International Atomic Energy Agency (IAEA), National Atomic Energy Agency, Argentina (CNEA) e Instituto de Pesquisas Energéticas e Nucleares (IPEN). A lista dos MRCs analisados está apresentada na Tabela 2, com os valores de suas frações mássicas de U. 
Tabela 2 - Dados dos materiais de referência certificados utilizados neste trabalho

\begin{tabular}{|c|c|c|c|}
\hline Código & $\begin{array}{l}\text { Materiais de } \\
\text { referência }\end{array}$ & $\begin{array}{c}\text { Valor da fração } \\
\text { mássica de U do } \\
\text { certificado, } \text { ng g }^{-1}\end{array}$ & Referência \\
\hline IAEA - 140/TM & $\begin{array}{l}\text { Trace Elements and } \\
\text { Methylmercury in } \\
\text { Seaweed (Fucus sp.) }\end{array}$ & $730(647-813)$ & IAEA (2000a) \\
\hline NIST - 1575 & Pine Needles & $20 \pm 4$ & NIST (1993a) \\
\hline NIST - 1632d & $\begin{array}{l}\text { Trace Elements in } \\
\text { Coal (Bituminous) }\end{array}$ & $517 \pm 12$ & NIST (2011) \\
\hline NIST - 1633b & $\begin{array}{l}\text { Constituent Elements } \\
\text { in Coal Fly Ash }\end{array}$ & $8790 \pm 360$ & NIST (1993b) \\
\hline INCT - M3 & Herring Tissue & $75,2 \pm 4,1$ & INCT (2015) \\
\hline IAEA - SOIL-7 & $\begin{array}{l}\text { Trace Elements in } \\
\text { Soil }\end{array}$ & $2600(2200-3300)$ & IAEA (2000b) \\
\hline NIST - $1566 b$ & Oyster Tissue & $255 \pm 1,4^{a}$ & NIST (2001) \\
\hline INCT - CTA-VTL-2 & $\begin{array}{l}\text { Virginia Tobacco } \\
\text { Leaves }\end{array}$ & $163 \pm 8^{a}$ & INCT (1997) \\
\hline INCT - OBTL-5 & $\begin{array}{l}\text { Oriental Basma } \\
\text { Tobacco Leaves }\end{array}$ & $113^{a}$ & INCT (2010) \\
\hline IPEN & Mexilhão & $112 \pm 16^{a}$ & MOREIRA (2010) \\
\hline IAEA - RLA2/014 & $\begin{array}{l}\text { Trace Elements in } \\
\text { Volcanic Ashes }\end{array}$ & $8500 \pm 600$ & CNEA (2016) \\
\hline
\end{tabular}

a - Valor informativo.

\subsubsection{Determinação da umidade nos materiais de referência certificados}

Para se utilizar MRCs é imprescindível conhecer as informações que estão disponíveis em seus certificados. Dentre essas informações, estão as instruções para determinação de umidade e a massa mínima do material que deve ser utilizada para garantir a obtenção de resultados confiáveis e exatos. Nestes materiais, os valores certificados das frações mássicas são dados na base seca. Portanto, para a comparação dos resultados obtidos com os valores certificados foi necessário determinar a umidade nos MRCs para calcular os resultados na base seca.

O procedimento de determinação de umidade se inicia com a pesagem de uma massa de 200 a $250 \mathrm{mg}$ de cada um dos materiais de referência, com exceção do MRC IAEA - RLA2/014 Trace Elements in Volcanic Ashes que a massa foi de aproximadamente $1 \mathrm{~g}$, em 
um pesa-filtro utilizando uma balança analítica. Para a secagem, foram usadas duas estufas distintas com intervalos de temperatura de operação diferentes, dependendo da matriz do MRC. A secagem dos materiais de origem biológica foi feita na estufa da marca FABBEPRIMAR Modelo $219 \mathrm{~d}$, a uma temperatura de $85^{\circ} \mathrm{C}$. Os materiais de origem geológica foram secos na estufa de secagem da marca FANEM Mod. $315 \mathrm{SE}$ a temperatura de $105^{\circ} \mathrm{C}$. Os tempos de secagem destes materiais variaram entre 24 e 72 horas ou até a amostra apresentar massa constante.

Após a secagem, os pesa-filtros foram colocados em dessecador até entrar em equilíbrio térmico com o ambiente e serem novamente pesados. Com a massa do material antes e após a secagem, foi realizado o cálculo da porcentagem de perda de umidade. As porcentagens de perda de umidade determinadas nos MRCs são apresentadas na Tabela 3 e estes resultados foram utilizados no cálculo das frações mássicas dos elementos na base seca.

Tabela 3 - Porcentagem de umidade nos materiais de referência certificados

\begin{tabular}{ccc}
\hline Código & $\begin{array}{c}\text { Material de referência } \\
\text { certificado }\end{array}$ & Teor de umidade, \% \\
IAEA - 140/TM & $\begin{array}{c}\text { Trace Elements and } \\
\text { Methylmercury in Seaweed } \\
(\text { Fucus sp. })\end{array}$ & 10,6 \\
NIST - 1575 & Pine Needles & 4,0 \\
NIST - 1632d & Trace Elements in Coal \\
(Bituminous) & 1,3 \\
NIST - 1633b & Constituent Elements in Coal \\
INCT - M3- MODAS-3 & Fly Ash & 1,6 \\
IAEA - SOIL-7 & Herring Tissue & 11,2 \\
IAEA - 1566b & Trace Elements in Soil & 1,1 \\
INCT - CTA-VTL-2 & Oyster Tissue & 7,3 \\
INCT - OBTL-5 & Virginia Tobacco Leaves & 4,7 \\
IPEN & Oriental Basma Tobacco & 5,2 \\
IAEA - RLA2/014 & Leaves & 10,8 \\
& Trace Elements in Volcanic & Ashes \\
\hline
\end{tabular}




\subsubsection{Amostras de biomonitores}

Neste trabalho foram analisados dois tipos de biomonitores, sendo eles cascas de árvores e bromélias. Nos últimos anos, esses materiais foram alvo de diversos estudos de biomonitoramento da poluição atmosférica, e.g., Figueiredo et al. (2007), Catinon et al. (2009) e Amato-Lourenco et al. (2016).

\subsubsection{Coleta das amostras de cascas de árvores}

A coleta das cascas de árvores das espécies Tipuana tipu (Tipuana) e Poincianella pluviosa (Sibipiruna) foi realizada entre janeiro e fevereiro de 2017 na Cidade Universitária Armando de Salles Oliveira (CUASO) da Universidade de São Paulo (USP). A CUASO está localizada na zona oeste da cidade de São Paulo, no bairro do Butantã, cujas coordenadas geográficas são $23^{\circ} 33^{\prime} 44^{\prime \prime S ~ e ~ 46 ³ ~ 43 ' 39 " W, ~ o c u p a n d o ~ u m a ~ a ́ r e a ~ t e r r i t o r i a l ~ d e ~ 76.314 .505,94 ~ m ² ~}$ com altitude média de 750 m (SEF-USP, 2014). O campus não apresenta trânsito intenso em seu interior, mas sofre influência do tráfego das rodovias ao seu entorno, como a Marginal Pinheiros e as rodovias Raposo Tavares, Castelo Branco, Anhanguera e Bandeirantes.

A cidade de São Paulo apresenta clima subtropical úmido, cujas principais características são invernos secos e verões chuvosos. O ano de 2017 foi considerado, de acordo com IAG-USP (2017), chuvoso, com acumulação pluviométrica de 16,7\% acima da média climatológica, quente, com temperaturas médias mensais maiores que a média climatológica e seco, com umidade relativa do ar abaixo da média climatológica.

No campus do Butantã, próximo ao IPEN, se localiza uma das estações de monitoramento da qualidade do ar da CETESB, a estação "Cidade Universitária-USP-IPEN". A área monitorada por essa estação foi considerada a mais poluída, em relação ao ozônio, da região metropolitana de São Paulo dentre as 21 estações da CETESB nos anos de 2014 e 2015. Entretanto, esse cenário não foi observado em 2016 e 2017 (CETESB, 2017).

Os oito pontos de coleta foram escolhidos aleatoriamente levando em consideração a presença das espécies arbóreas. Os pontos de coleta e suas respectivas localizações estão ilustrados no mapa da Figura 6. 
Figura 6 - Mapa da localização dos pontos de amostragem das cascas de árvores.

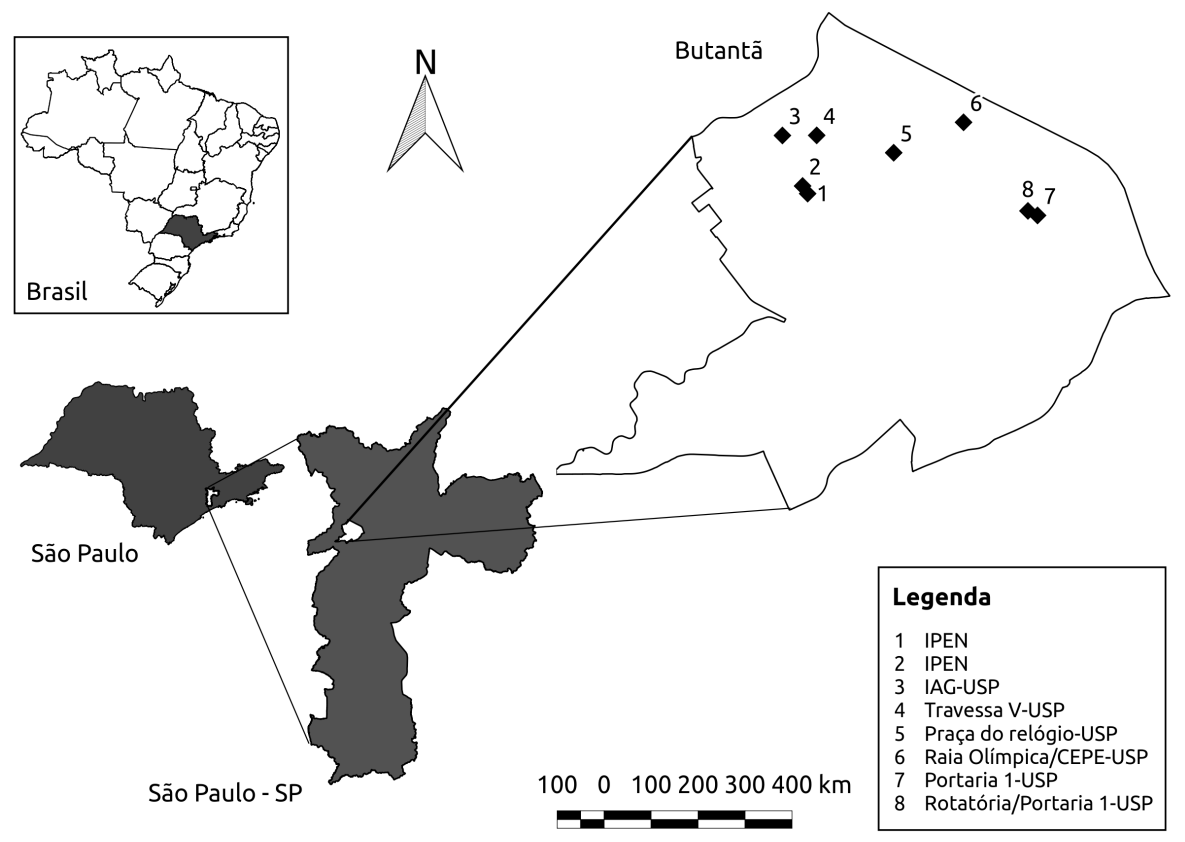

Fonte: Autora da dissertação.

Os dados das amostras coletadas, bem como a localização (coordenadas geográficas) das árvores que tiveram cascas amostradas, estão apresentados na Tabela 4. As cascas foram coletadas a uma altura de aproximadamente $150 \mathrm{~cm}$ do solo, com o auxílio de uma faca de aço inoxidável. Foi medida a circunferência do tronco da árvore no ponto coletado e posteriormente calculado o seu diâmetro. Essas cascas foram armazenadas em sacos de papel, ao invés de plástico, para evitar a formação de mofo.

\subsubsection{Tratamento das amostras de cascas de árvores}

As amostras armazenadas em sacos de papel foram submetidas à secagem em estufa da marca FANEM Mod. 320-SE com circulação de ar forçada a $40{ }^{\circ} \mathrm{C}$ por cerca de 48 horas. Posteriormente, as cascas de árvores foram limpas, com o auxílio de escovas com cerdas de nylon, para retirar impurezas superficiais na forma de pó. A amostra para análise foi obtida, inicialmente, pela remoção de cerca de $3 \mathrm{~mm}$ da camada externa da casca com um ralador de titânio, seguida de moagem em um micromoinho vibratório "Analysette 3 Pulverisette 0" da marca Fritsch com almofariz e bola de ágata. Por fim, a amostra obtida, na forma de um pó fino, foi armazenada em frasco plástico limpo. Os frascos contendo as amostras foram identificados e acomodados em um dessecador de vidro com sílica, no seu interior, para evitar a absorção da umidade do ambiente. 
Tabela 4 - Dados das amostras de cascas de árvores coletadas na Cidade Universitária.

\begin{tabular}{|c|c|c|c|c|c|}
\hline $\begin{array}{l}\text { Casca de } \\
\text { Árvore }\end{array}$ & $\begin{array}{l}\text { Espécie de } \\
\text { árvore }\end{array}$ & $\begin{array}{c}\text { Local da } \\
\text { coleta }\end{array}$ & $\begin{array}{l}\text { Coordenadas } \\
\text { geográficas }\end{array}$ & $\begin{array}{c}\text { Data da } \\
\text { coleta }\end{array}$ & $\begin{array}{c}\text { Responsável } \\
\text { pela coleta }\end{array}$ \\
\hline 1 & $\begin{array}{l}\text { Tipuana tipu } \\
\text { (Tipuana) }\end{array}$ & IPEN & $\begin{array}{l}23^{\circ} 33^{\prime} 47.9^{\prime \prime} \mathrm{S} \\
46^{\circ} 44^{\prime} 01.3^{\prime \prime} \mathrm{W}\end{array}$ & $11 / 01 / 2017$ & Nicole/Mitiko \\
\hline 2 & $\begin{array}{c}\text { Poincianella } \\
\text { pluviosa } \\
\text { (Sibipiruna) }\end{array}$ & IPEN & $\begin{array}{l}23^{\circ} 33^{\prime} 45.6^{\prime \prime} \mathrm{S} \\
46^{\circ} 44^{\prime} 02.9^{\prime \prime} \mathrm{W}\end{array}$ & $11 / 01 / 2017$ & Nicole/Mitiko \\
\hline 3 & $\begin{array}{l}\text { Tipuana tipu } \\
\text { (Tipuana) }\end{array}$ & IAG - USP & $\begin{array}{l}23^{\circ} 33^{\prime} 30.3^{\prime \prime} \mathrm{S} \\
46^{\circ} 44^{\prime} 09.3^{\prime \prime} \mathrm{W}\end{array}$ & $14 / 02 / 2017$ & Nicole \\
\hline 4 & $\begin{array}{c}\text { Poincianella } \\
\text { pluviosa } \\
\text { (Sibipiruna) }\end{array}$ & $\begin{array}{c}\text { Travessa V - } \\
\text { USP }\end{array}$ & $\begin{array}{l}23^{\circ} 33^{\prime} 30.4^{\prime \prime} \mathrm{S} \\
46^{\circ} 43^{\prime} 58.1^{\prime \prime W}\end{array}$ & $14 / 02 / 2017$ & Nicole \\
\hline 5 & $\begin{array}{l}\text { Tipuana tipu } \\
\text { (Tipuana) }\end{array}$ & $\begin{array}{l}\text { Praça do } \\
\text { relógio - } \\
\text { USP }\end{array}$ & $\begin{array}{l}23^{\circ} 33^{\prime} 35.9^{\prime \prime} \mathrm{S} \\
46^{\circ} 43^{\prime} 33.0^{\prime \prime} \mathrm{W}\end{array}$ & $14 / 02 / 2017$ & Nicole \\
\hline 6 & $\begin{array}{c}\text { Poincianella } \\
\text { pluviosa } \\
\text { (Sibipiruna) }\end{array}$ & $\begin{array}{c}\text { Raia } \\
\text { olímpica/ } \\
\text { CEPE-USP }\end{array}$ & $\begin{array}{l}23^{\circ} 33^{\prime} 27.0^{\prime \prime} \mathrm{S} \\
46^{\circ} 43^{\prime} 10.0^{\prime \prime} \mathrm{W}\end{array}$ & $14 / 02 / 2017$ & Nicole \\
\hline 7 & $\begin{array}{l}\text { Tipuana tipu } \\
\text { (Tipuana) }\end{array}$ & $\begin{array}{l}\text { Portaria } 1 \text { - } \\
\text { USP }\end{array}$ & $\begin{array}{l}23^{\circ} 33^{\prime} 55.3^{\prime \prime} \mathrm{S} \\
46^{\circ} 42^{\prime} 46.2^{\prime \prime} \mathrm{W}\end{array}$ & $14 / 02 / 2017$ & Nicole \\
\hline 8 & $\begin{array}{l}\text { Tipuana tipu } \\
\text { (Tipuana) }\end{array}$ & $\begin{array}{c}\text { Rotatória da } \\
\text { portaria } 1 \text { - } \\
\text { USP }\end{array}$ & $\begin{array}{l}23^{\circ} 33^{\prime} 53.9^{\prime \prime} \mathrm{S} \\
46^{\circ} 42^{\prime} 49.3^{\prime \prime} \mathrm{W}\end{array}$ & $14 / 02 / 2017$ & Nicole \\
\hline
\end{tabular}

\subsubsection{Amostras de bromélias}

Foram doadas pela Faculdade de Medicina da USP (FMUSP) cinco amostras de bromélias da espécie Tillandsia usneoides L., em forma de pó, prontas para a análise. As amostras de bromélias foram expostas em diferentes pontos da cidade de São Paulo e na região de Osasco. O procedimento de coleta e preparo dessas amostras está descrito nos trabalhos de Figueiredo et al. (2007) e Amato-Lourenco et al. (2016). 


\subsubsection{Preparo do padrão sintético de urânio}

$\mathrm{Na}$ análise por ativação com nêutrons pelo método comparativo, a exatidão e a precisão dos resultados dependem da qualidade do padrão sintético. Portanto, para o preparo do padrão sintético de $U$ foram utilizados materiais volumétricos previamente verificados em relação à calibração. O processo da verificação da calibração do pipetador automático está descrito no item 5.2 desta dissertação. A solução padrão de U utilizada no padrão sintético foi preparada a partir da diluição de $5 \mathrm{~mL}$ da solução estoque certificada de concentração $1003 \pm 3 \mathrm{mg} \mathrm{L}^{-1}$ da Spex CertPrep USA em um balão volumétrico de $25 \mathrm{~mL}$ com água purificada. Esta solução de U diluída teve o volume de $50 \mu \mathrm{L}$ pipetados em uma tira de papel de filtro Whatman $\mathrm{N}^{o} 40$, com dimensão de $1,5 \mathrm{~cm} \times 6,0 \mathrm{~cm}$, mantida na posição vertical com o auxílio de dois bastões de vidro, como mostra a Figura 7.

Figura 7 - Fotografia mostrando a solução padrão sendo pipetada em tiras de papel de filtro.

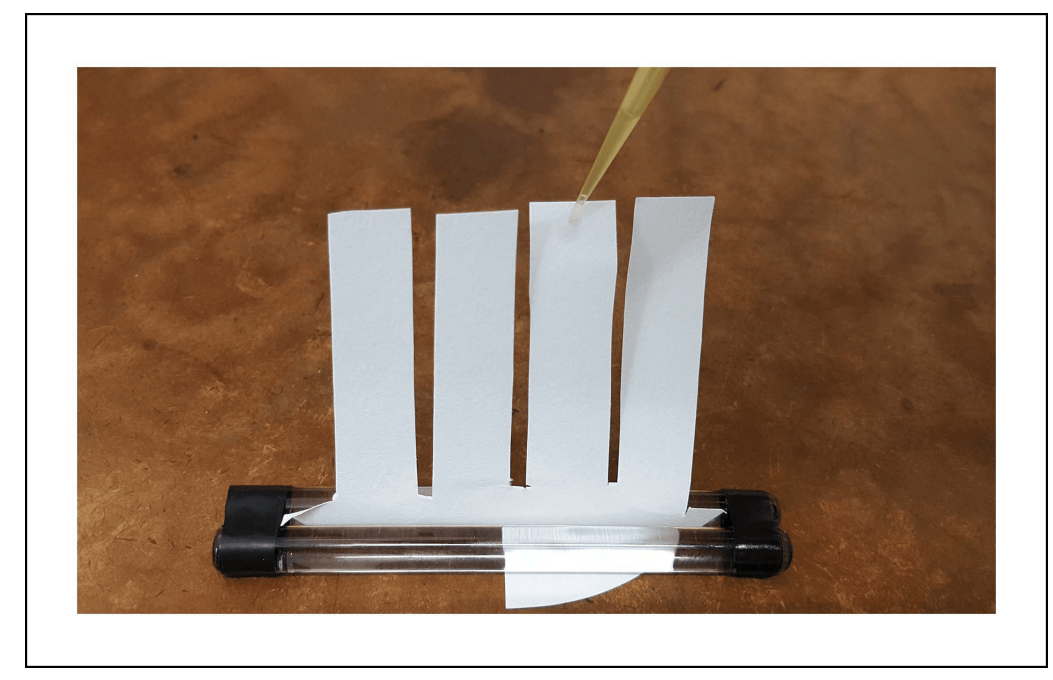

Fonte: Autora da dissertação.

Para a secagem da alíquota pipetada, as tiras de papel de filtro foram colocadas em um dessecador. Após cerca de 15 horas, cada tira foi cortada em sua base, dobrada e acondicionada em envelope de polietileno. Estes envelopes foram confeccionados utilizando uma folha de polietileno incolor previamente desmineralizada usando solução de ácido nítrico diluído e água purificada, seguida de secagem a temperatura ambiente. Foi utilizada uma seladora elétrica tanto na confecção desses envelopes, quanto para lacrá-los. Os dados da solução padrão de U utilizado estão apresentados na Tabela 5. 
Tabela 5 - Dados da solução padrão e da massa de U irradiada.

\begin{tabular}{ccc}
\hline Elemento & Concentração, $\mu \mathbf{g} \mathbf{m L}^{-1}$ & $\begin{array}{c}\text { Massa do elemento em 50 } \\
\mu \mathbf{L} \text { de solução, } \boldsymbol{\mu} \mathbf{g}\end{array}$ \\
\hline $\mathrm{U}$ & $200,51 \pm 0,60$ & $10,02 \pm 0,03$ \\
\hline
\end{tabular}

\subsubsection{Pesagem dos materiais de referência certificados e das amostras para análise}

Para realizar as análises dos MRCs e das amostras de biomonitores foram feitas pesagens de alíquotas desses materiais em envelopes de polietileno. Para os materiais de origem geológica foi pesada uma massa de aproximadamente $100 \mathrm{mg}$ e no caso dos materiais de origem biológica foi pesada uma massa de cerca $200 \mathrm{mg}$. Nestas pesagens, utilizouse uma balança analítica da marca SHIMADZU modelo AUW220D, com a precisão de $\pm 0,00001 \mathrm{~g}$. Na Figura 8 é mostrado cada envelope contendo a alíquota de amostra pesada e sua identificação, bem como o padrão de U (U3).

Figura 8 - Fotografia do padrão e das alíquotas de amostras em envelopes de polietileno.

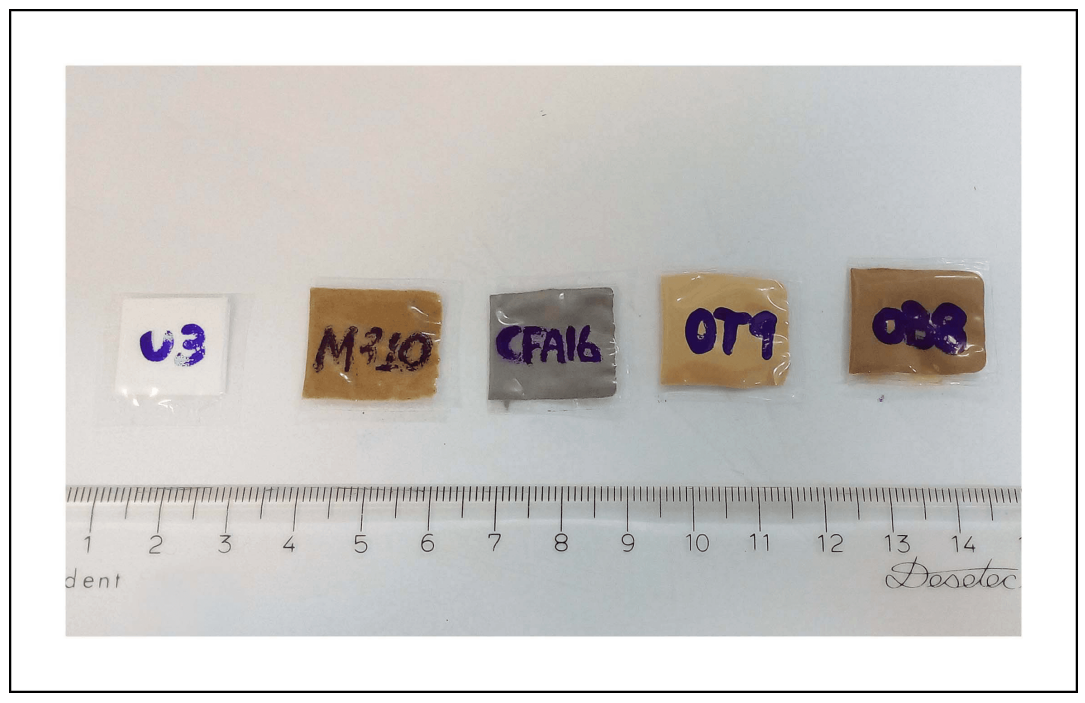

Fonte: Autora da dissertação.

\subsection{Verificação da calibração do pipetador}

Foi feita a verificação da calibração do pipetador Eppendorf para a capacidade de $50 \mu \mathrm{L}$, com o intuito de evitar erros na preparação do padrão sintético de U. Inicialmente, os materiais utilizados foram mantidos na sala de pesagens para que atingissem o equilíbrio térmico com o ambiente. Então, o procedimento para a verificação da calibração do pipetador consistiu em realizar pesagens de alíquotas de $50 \mu \mathrm{L}$ de água purificada pipetadas em um pesa-filtro utilizando uma balança analítica. Foram feitas pesagens de dez alíquotas de $50 \mu \mathrm{L}$. A temperatura da água purificada foi medida antes e depois da pesagem das alíquotas e a 
temperatura média foi utilizada para obter o valor da densidade da água, consultado em Perry (1941). Em seguida, foi calculado o volume correspondente a massa da alíquota pipetada. Para avaliar a reprodutibilidade nos resultados, foram calculados o volume médio $(\overline{\mathrm{V}})$, o desvio padrão (DP), o desvio padrão relativo (DPR) e, para avaliar a exatidão, o erro relativo (ER). Os resultados da verificação da calibração do pipetador se encontram no item 7.1 desta dissertação.

\subsection{Ensaios preliminares}

Foram realizados os ensaios preliminares da determinação de $\mathrm{U}$ em envelopes de polietileno e tiras de papel de filtro conforme descritos nesta seção.

\subsubsection{Determinação de urânio como impureza em envelopes de polietileno usados na irradiação de amostras e padrões}

A verificação da presença de U como impureza nos envelopes de polietileno utilizados na irradiação das amostras e dos padrões foi feita uma vez que estes envelopes não são removidos para as medições. Este procedimento teve como objetivo verificar se o U presente nestes envelopes não afetaria os resultados das análises. Para isso, foram confeccionados dois envelopes utilizando folha de polietileno previamente desmineralizada, nas mesmas dimensões daquelas usadas na irradiação da amostra ou do padrão. A massa e a área de cada envelope foram de aproximadamente $0,03700 \mathrm{~g} \mathrm{e} 8 \mathrm{~cm}^{2}$, respectivamente. Estes envelopes foram analisados por meio de análise por ativação com nêutrons epitérmicos com irradiações de longa e de curta duração. As condições experimentais usadas na irradiação de longa e curta duração estão descritas nos itens 5.4.1.2 e 5.4.2.2, respectivamente.

\subsubsection{Determinação de urânio como impureza no papel de filtro usado como suporte no preparo do padrão sintético}

Foi realizada a verificação da presença de U como impureza no papel de filtro Whatman $\mathrm{N}^{o} 40$ utilizado no preparo do padrão sintético. O objetivo desta análise foi verificar se a contribuição do U presente na tira de papel de filtro não estaria afetando os resultados das análises. Foram preparadas duas amostras de tira de papel de filtro Whatman $\mathrm{N}^{o} 40$, cada uma com área de $10,4 \mathrm{~cm}^{2}$ e massa de aproximadamente $0,1 \mathrm{~g}$. As tiras de papel de filtro foram analisadas por ENAA com irradiações de longa e curta duração e as condições experimentais utilizadas nessas análises estão descritas nos itens 5.4.1.2 e 5.4.2.2, respectivamente. 


\subsection{Procedimento de análise por ativação com nêutrons}

\subsubsection{Irradiações de longa duração}

Nas irradiações de longa duração, as amostras e os padrões foram submetidos à irradiação no núcleo do reator nuclear IEA-R1 do IPEN - CNEN/SP por um ciclo de cerca de 8 horas. A determinação do ${ }^{238} \mathrm{U}$ foi realizada pela medição dos picos de energia dos raios gama de 106,12 e $277,60 \mathrm{keV}$ do ${ }^{239} \mathrm{~Np}$, cuja meia-vida é igual a 2,36 dias (LBNL, 2018).

\subsubsection{Análise instrumental por ativação com nêutrons térmicos de longa duração}

Na INAA, as amostras e o padrão sintético de U, colocados em envelope de polietileno foram envoltos em folha de alumínio individualmente e depois acondicionados em um dispositivo de alumínio para ser submetido à irradiação sob fluxo de nêutrons térmicos de $4,0 \times 10^{12}$ a $4,4 \times 10^{12} \mathrm{n} \mathrm{cm}^{-2} \mathrm{~s}^{-1}$ por um período de 8 horas. Na Figura 9 podem ser vistos os materiais utilizados no preparo das amostras e do padrão para irradiação de longa duração com nêutrons térmicos. As amostras irradiadas foram abertas sob supervisão da proteção radiológica após 7 dias de decaimento.

Figura 9 - Fotografia do dispositivo de alumínio, suporte de aço inoxidável, padrão e amostras em envelopes de polietileno embrulhadas em folha de alumínio.

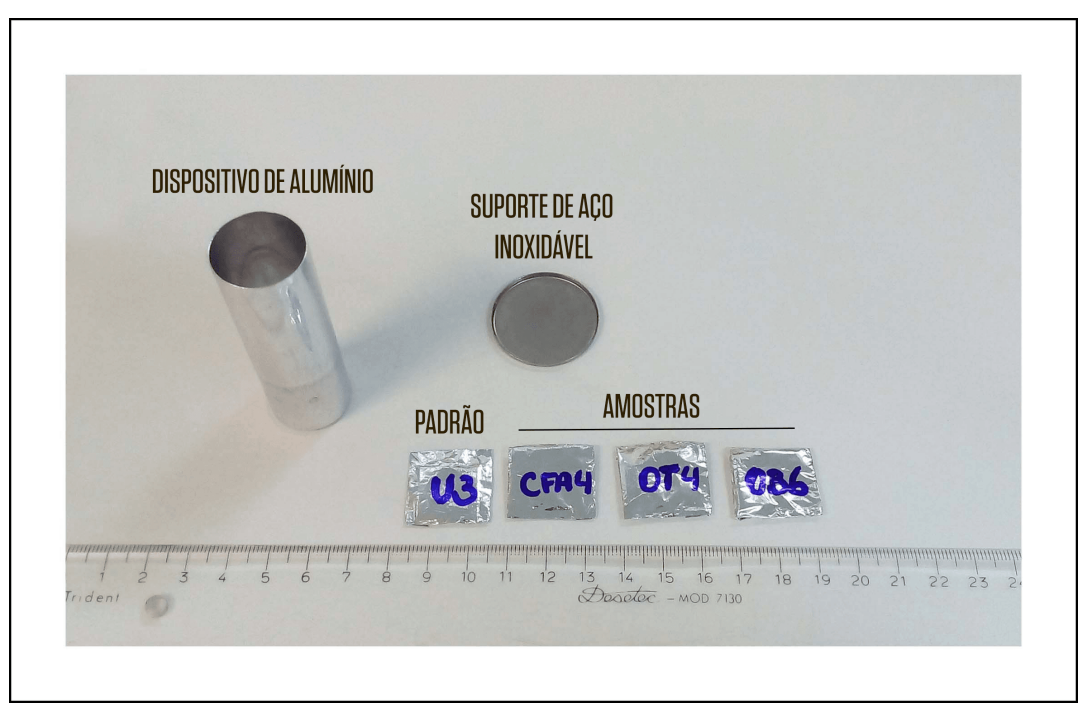

Fonte: Autora da dissertação.

Para as contagens, as amostras e o padrão irradiados foram montados em suportes de aço inoxidável. Essas amostras e o padrão devidamente identificados, foram colocados em blindagens de chumbo e levados para a sala de contagem. As medições foram realizadas usando um detector de Ge hiperpuro (HPGe), modelo GC2018 ligado a um analisador de espectro digital DSA 1000, ambos da marca CANBERRA. A resolução (FWHM) do sistema utilizado foi de $1,05 \mathrm{keV}$ para o pico de $121,97 \mathrm{keV}$ do ${ }^{57} \mathrm{Co}$ e de $1,89 \mathrm{keV}$ para o pico de 
$1331,5 \mathrm{keV}$ do ${ }^{60} \mathrm{Co}$. Para aquisição dos dados espectrais e seu processamento foi utilizado o software Genie 2000 versão 3.1 da CANBERRA. Foram realizadas, diariamente, verificações do funcionamento do sistema, fazendo a contagem de uma fonte radioativa de ${ }^{57} \mathrm{Co}+{ }^{60} \mathrm{Co}$. As contagens das amostras e do padrão foram feitas escolhendo previamente à sua geometria de contagem (distância entre a amostra e o detector), de modo que a porcentagem do tempo morto seja menor que $10 \%$.

Os tempos de contagem foram de 5400 s para o padrão e variaram de 20000 a 36000 s para a amostra. As contagens das amostras e do padrão foram realizadas com dois diferentes tempos de decaimento, sendo 7 dias para a primeira contagem e 9 dias para a segunda contagem.

\subsubsection{Análise por ativação com nêutrons epitérmicos de longa duração}

$\mathrm{Na}$ ENAA, as amostras e o padrão de U foram também embrulhados em folha de alumínio e acondicionados no interior de uma cápsula de cádmio de aproximadamente $1 \mathrm{~mm}$ de espessura, que foi inserida em um dispositivo de alumínio e submetida à irradiação sob fluxo de nêutrons térmicos de 4,2 $\times 10^{12}$ a $4,5 \times 10^{12} \mathrm{n} \mathrm{cm}^{-2} \mathrm{~s}^{-1}$ por um período de 8 horas. Na Figura 10, são apresentados os materiais utilizados na ENAA de longa duração. Os tempos de decaimento usados nas medições foram de 2 dias para primeira contagem e 4 dias para a segunda contagem. A montagem das amostras e do padrão para as contagens, bem como o sistema utilizado foi o mesmo descrito para INAA. Os tempos de contagem também foram os mesmos utilizados para INAA.

Figura 10 - Fotografia do dispositivo de alumínio, suporte de aço inoxidável, cápsula de cádmio, padrão e amostras em envelopes de polietileno embrulhadas em folha de alumínio.

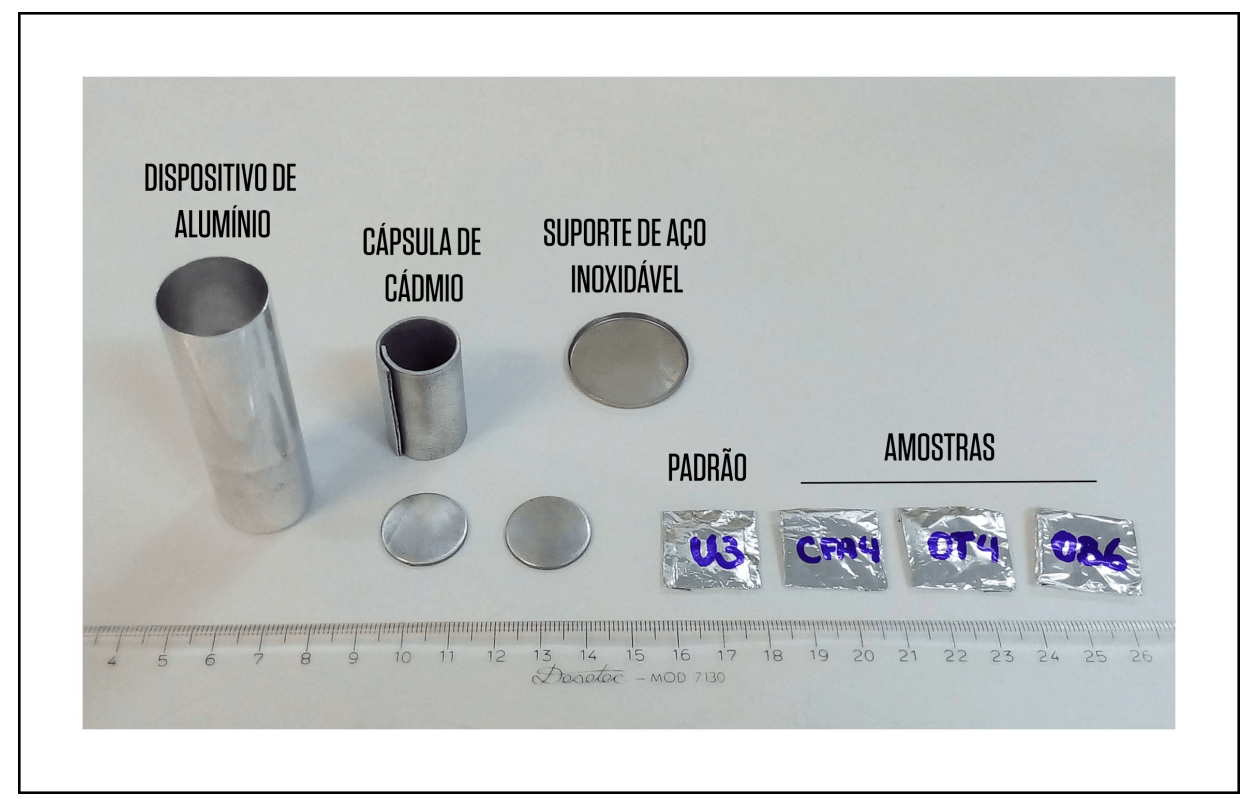

Fonte: Autora da dissertação. 


\subsubsection{Irradiações de curta duração}

No caso das irradiações de curta duração, as amostras e os padrões foram submetidos à irradiação na estação pneumática $\mathrm{N}^{o} 4$ do reator de pesquisas IEA-R1 do IPEN - CNEN/SP sob o fluxo de nêutrons térmicos de $1,9 \times 10^{12} \mathrm{n} \mathrm{cm}^{-2} \mathrm{~s}^{-1}$. Os tempos de irradiação utilizados variaram de 15 a $60 \mathrm{~s}$, dependendo do tipo de amostra analisada. A determinação do ${ }^{238} \mathrm{U}$ foi realizada pela medição do pico de energia dos raios gama de $74,66 \mathrm{keV}$ do ${ }^{239} \mathrm{U}$ com meia-vida de 23,47 $\min$ (LBNL, 2018).

\subsubsection{Análise instrumental por ativação com nêutrons térmicos de curta duração}

Na INAA de curta duração, as amostras e padrão, individualmente pesados em invólucros de polietileno, foram inseridos em outro envelope plástico e colocados dentro de um dispositivo de polietileno. Estes materiais são apresentados na fotografia da Figura 11. Este dispositivo, contendo a amostra e o padrão, foi submetido à irradiação na estação pneumática $\mathrm{N}^{o} 4$ do reator IEA-R1 por um período que variou de 15 a $60 \mathrm{~s}$, dependendo da amostra. Foi utilizado um cronômetro para registrar o tempo inicial, quando termina a irradiação, e final, quando acabam as medições da atividade da amostra e do padrão. As medições das atividades foram realizadas com o tempo de decaimento entre 4 e 25 min, dependendo da amostra. O sistema de contagem foi o mesmo utilizado na irradiação de longa duração. Os tempos de contagens utilizados foram de $500 \mathrm{~s}$, tanto para a amostra quanto para o padrão.

Figura 11 - Fotografia do dispositivo de polietileno, suporte de aço inoxidável, padrão e amostras em envelopes de polietileno.

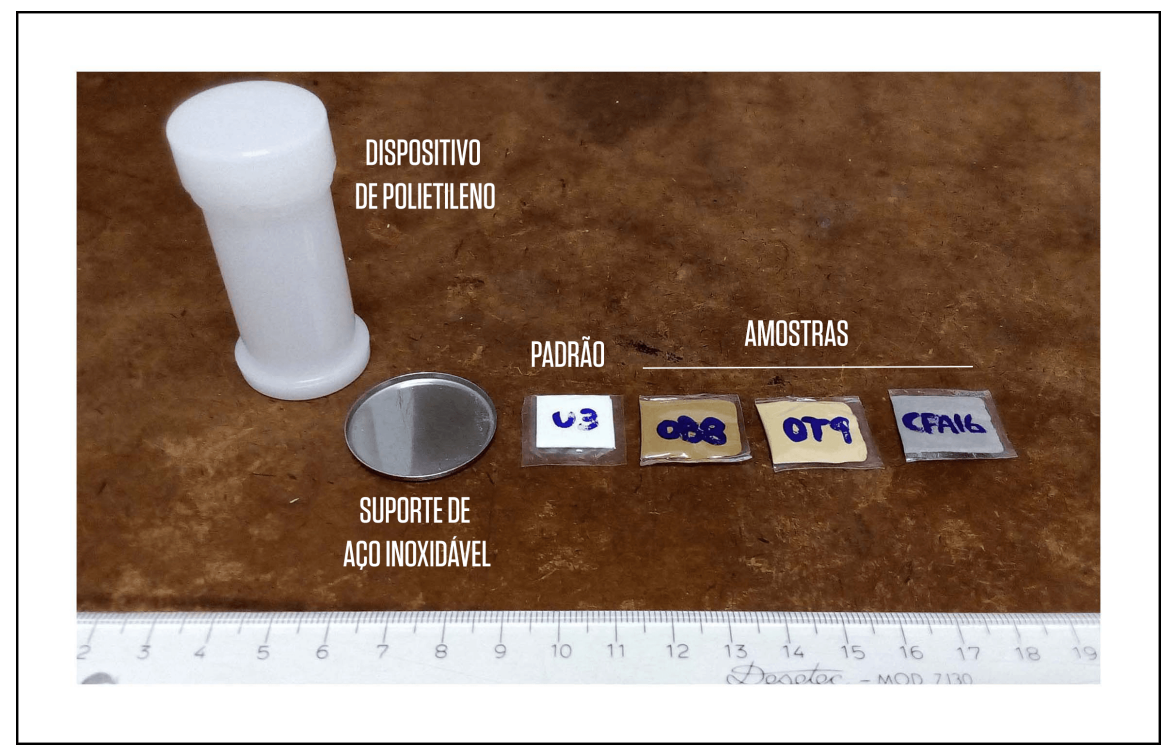

Fonte: Autora da dissertação. 


\subsubsection{Análise por ativação com nêutrons epitérmicos de curta duração}

Para realizar a ENAA de curta duração, a amostra e o padrão foram colocados em um envelope de polietileno e acomodados dentro de uma cápsula de cádmio de aproximadamente $1 \mathrm{~mm}$ de espessura. Esta cápsula de cádmio foi envolta em um novo envelope de polietileno e inserida em um dispositivo de polietileno. Para evitar eventual abertura da cápsula de cádmio, foi utilizado um calço de espuma de nylon. Na Figura 12, se encontra a fotografia dos dispositivos utilizados na irradiação epitérmica de curta duração.

A irradiação foi realizada na estação pneumática $\mathrm{N}^{o} 4$ do reator IEA-R1 pelo período de 25 a $40 \mathrm{~s}$, dependendo da amostra. O tempo de decaimento para as contagens foi de cerca de $4 \mathrm{~min}$. O procedimento para a contagem e o sistema utilizado foram aqueles usados na INAA. Os tempos de contagens usados para amostra e o padrão foram de $500 \mathrm{~s}$.

Figura 12 - Fotografia do dispositivo de polietileno, suporte de aço inoxidável, cápsula de cádmio, calço de espuma de nylon, padrão e amostras em envelopes de polietileno.

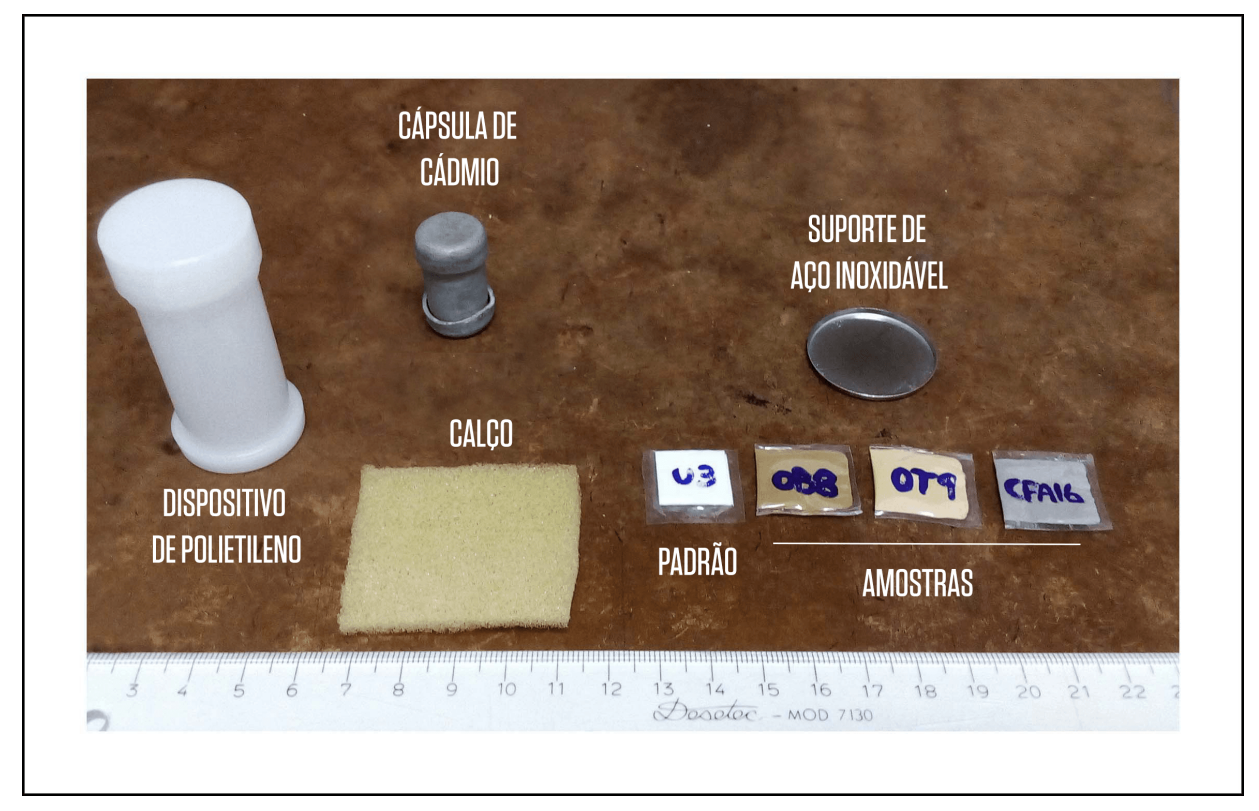

Fonte: Autora da dissertação. 


\section{TRATAMENTO DE DADOS}

Os resultados obtidos neste trabalho foram tratados usando estatística básica calculando parâmetros como a média aritmética (M), o desvio padrão (DP), o desvio padrão relativo (DPR) e o erro relativo (ER). Para avaliar a precisão e a exatidão dos resultados, foram calculados o valor de HorRat (HORWITZ; ALBERT, 2006) e a diferença padronizada ou Z score (BODE, 1996), respectivamente. Também foram calculados os limites de detecção e quantificação (CURRIE, 1999) para determinar a quantidade mínima detectável e quantificável do elemento na amostra. Para identificar e eliminar resultados extremos ou outliers do conjunto de dados, foi aplicado o teste de Grubbs (GRUBBS, 1969) e a comparação das médias dos resultados obtidos foi realizada com a análise de variância, a ANOVA, ambos a nível de significância de 0,05 .

\subsection{Diferença padronizada ( $\mathrm{Z}$ score $)$}

A diferença padronizada $\mathrm{z}$ ( $\mathrm{Z}$ score) permite avaliar a exatidão dos resultados. Esta grandeza leva em consideração as frações mássicas e as incertezas dos resultados obtidos e dos valores certificados dos MRCs. A expressão do Z score, segundo Bode (1996), é dada pela relação 15 .

$$
z_{i}=\frac{C_{i}-C_{r e f, i}}{\sqrt{\sigma_{i}^{2}+\sigma_{r e f, i}^{2}}}
$$

onde $C_{i}$ e $\sigma_{i}$ são a fração mássica e a incerteza obtidas, respectivamente; $C_{r e f, i}, \sigma_{r e f, i}$ são a fração mássica e a incerteza dos valores certificados, respectivamente. Os resultados com valores de $\mathrm{z}$, em módulo, menores ou iguais a 2 são considerados satisfatórios em relação aos resultados certificados ao nível de significância de 0,05 (BODE, 1996).

\subsection{Valor de HorRat}

Outro importante parâmetro para avaliação de resultados analíticos é a sua reprodutibilidade, isto é, a precisão dos dados obtidos. De acordo com Horwitz e Albert (2006), a precisão dos resultados depende da fração mássica do analito na amostra. Para se realizar a avaliação adequada dos valores de $D P R$ obtidos pode-se usar o critério descrito por Wood (1999), calculando o valor de HorRat. Este valor pode ser obtido pela equação 16 (HORWITZ; ALBERT, 2006).

$$
\text { HorRat }=\frac{D P R}{D P R P}
$$


em que $D P R$ é o desvio padrão relativo obtido nos dados experimentais e $D P R P$ é o valor dado pela equação 17 (WOOD, 1999).

$$
D P R P=2^{1-0,5 \log C},
$$

onde $C$ é a fração mássica do elemento determinada na amostra. O valor de HorRat é considerado adequado quando menor ou igual a dois (WOOD, 1999).

\subsection{Limites de detecção e de quantificação}

Os limites de detecção (LD) e de quantificação (LQ) de um método indicam as quantidades mínimas detectáveis e quantificáveis de um elemento numa amostra. Estes limites são parâmetros analíticos que devem ser avaliados na validação de uma metodologia. $\mathrm{Na}$ NAA, os limites de detecção e quantificação são calculados, em taxas de contagens, segundo Currie (1999), pelas equações 18 e 19.

$$
\begin{gathered}
L D_{T}=3,29 \frac{\sqrt{B G}}{L T}, \\
L Q_{T}=10 \frac{\sqrt{B G}}{L T},
\end{gathered}
$$

onde $L D_{T}$ e $L Q_{T}$ são as taxas de contagens correspondentes às frações mássicas mínimas detectáveis e quantificáveis, respectivamente; BG é taxa de contagem de fundo (background), ou seja, a área sob o pico e LT é o tempo de medição ou contagem. Uma vez obtidos os valores de $L D_{T}$ e $L Q_{T}$, as frações mássicas mínimas dos elementos são calculadas, em unidades de fração mássica, pelo método comparativo.

\subsection{Teste de Grubbs}

Os testes de valores extremos ou outliers são usados para verificar a presença de valores atípicos em um conjunto de dados amostrais que configuram uma distribuição. Esses valores extremos podem ser considerados manifestações extremas da variabilidade aleatória inerente aos dados. Além disso, os outliers podem ser resultantes de desvios do procedimento experimental ou de um erro de cálculo do analista (GRUBBS, 1969). O teste de Grubbs consiste em um cálculo estatístico cujo resultado permite decidir se um valor duvidoso é um outlier. Esse cálculo é realizado pela equação 20.

$$
T_{n}=\frac{\left(x_{n}-\bar{x}\right)}{D P}
$$

onde $x_{n}$ é o valor duvidoso (extremo), $\bar{x}$ é a média aritmética de todos os $n$ valores e $D P$ é o desvio padrão do conjunto de dados.

De acordo com Grubbs (1969), o valor $\mathrm{T}_{n}$ deve ser comparado a um valor tabelado $\mathrm{T}_{c}$ que depende do número de observações ( $n$ ) e do nível de significância. $\mathrm{Se}_{n}>\mathrm{T}_{c}$, o valor 
duvidoso pode ser considerado um outlier e rejeitado do conjunto de dados a um nível de significância escolhido. Por outro lado, se $\mathrm{T}_{c}>\mathrm{T}_{n} \mathrm{o}$ valor duvidoso não pode ser considerado outlier e deve ser mantido no conjunto de dados.

\subsection{Análise de variância (ANOVA)}

A análise de variância, ou ANOVA, é uma abordagem estatística que possibilita verificar hipóteses sobre as médias de populações e concluir se as diferenças amostrais são reais ou causais, ou seja, se as populações avaliadas apresentam diferenças significativas ou decorrentes da variabilidade amostral. Dessa maneira, a ANOVA compara médias de diferentes populações para verificar se elas são iguais ou não, o que permite a comparação de vários grupos de dados de uma vez só (MILONE, 2004). Os pressupostos da ANOVA são:

- As amostras são aleatórias e independentes;

- As populações apresentam distribuição normal;

- As variâncias populacionais são iguais.

Entretanto, esses pressupostos não precisam ser absolutamente satisfeitos e os resultados da análise são empiricamente verdadeiros sempre que as populações forem aproximadamente normais e possuírem variâncias próximas (MILONE, 2004). Para verificar o segundo pressuposto, antes da aplicação da ANOVA foi utilizado o teste Shapiro-Wilk para normalidade a um nível de significância 0,05 . O pressuposto de normalidade não foi cumprido em alguns conjuntos de dados obtidos para determinadas amostras, porém, nesses casos as distribuições eram aproximadamente normais. Os conjuntos de dados também foram submetidos a um teste de variância, o teste de Levene. O pressuposto de variâncias iguais também não foi verificado em algumas amostras, mas, nestes casos, as variâncias foram próximas.

\subsubsection{Teste de Tukey}

A análise de variância determina se há diferença entre as médias das populações, entretanto, ela não especifica quais grupos são diferentes. Dessa maneira, quando há diferença significativa entre as médias das populações, pode-se aplicar um teste post-hoc para avaliar como diferem esses grupos. O teste de Tukey (TUKEY, 1949) é um teste post-hoc que consiste em comparações múltiplas, onde as médias são comparadas em pares para todas possibilidades. Essas comparações são baseadas na diferença mínima significativa e levam em consideração os percentis do grupo. Nos casos em que a ANOVA apontou que haviam diferenças significativas entre as médias das frações mássicas comparadas, o teste de Tukey, permitiu determinar como diferiam essas médias. 


\subsection{Estimativa da incerteza da determinação de um elemento pela análise por ativação com nêutrons}

Um importante parâmetro a ser avaliado na análise dos resultados é a incerteza de medição. A incerteza é uma variável que indica a qualidade de uma medida de forma quantitativa (JCGM-INMETRO, 2008). De acordo com EURACHEM (2012), o processo de estimativa da incerteza de medição pode ser dividido em quatro passos, a saber:

- Especificação do mensurando;

- Identificação das fontes de incerteza;

- Quantificação das contribuições das fontes de incerteza;

- Cálculo da incerteza combinada.

Neste trabalho, o mensurando é a fração mássica de U determinada por INAA e ENAA pelo método comparativo. Com relação às fontes de incerteza, em análise por ativação elas podem ser divididas em três grupos, a saber: Preparação da amostra e do padrão, irradiação e medição por espectrometria gama (KUČERA et al., 2004). Na Figura 13 estão apresentadas as fontes de incerteza associadas às grandezas de entrada utilizadas no cálculo da fração mássica de um elemento por INAA ou ENAA pelo método comparativo.

Para a quantificação das contribuições das fontes de incerteza, foram consideradas as incertezas associadas à diluição da solução padrão, ao preparo do padrão sintético, à pesagem das amostras, à constante de decaimento e às estatísticas de contagens. Foram usados os valores de desvio padrão relativo (DPR) obtidos na verificação da calibração das pipetas e do balão volumétrico para quantificar as contribuições de incerteza relativas ao analista. 
Figura 13 - Diagrama de Ishikawa para a determinação da incerteza combinada da fração mássica de elementos por INAA ou ENAA.

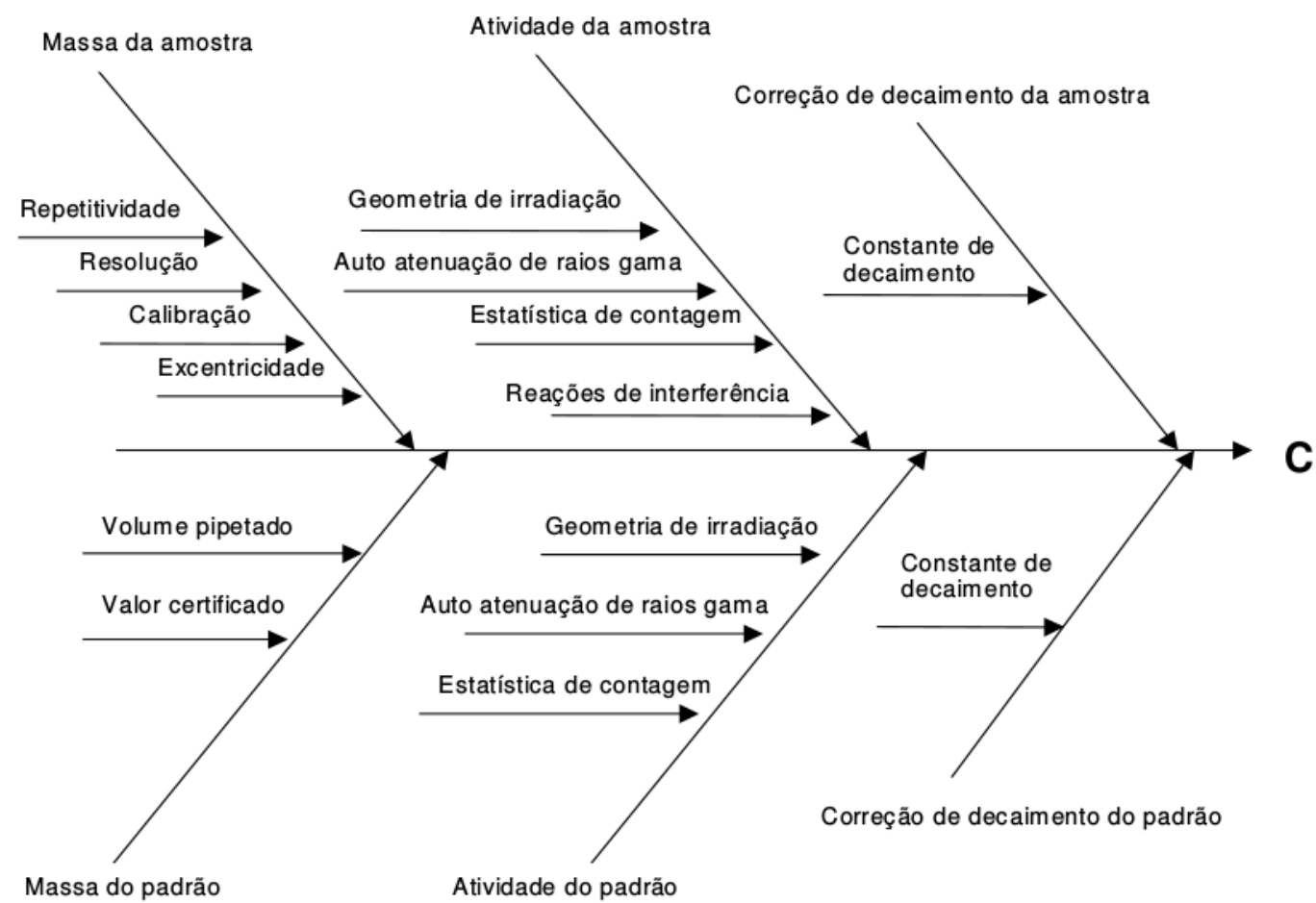

Fonte: MOREIRA (2010).

Também foi usada a incerteza da concentração da solução padrão para quantificar a contribuição em relação ao produtor. As fontes de incerteza e os parâmetros avaliados, com seus respectivos tipos de incerteza (A ou B) e distribuições, para a determinação de U neste trabalho, estão apresentados na Tabela 6.

O cálculo da incerteza combinada foi realizado de acordo com o método simulado proposto por EURACHEM (2012). Para o cálculo da incerteza expandida, considerou-se o fator de abrangência $k=2$ para um nível de significância de 0,05 . 
Tabela 6 - Fontes de incerteza e parâmetros para a determinação da incerteza combinada da fração mássica de U por INAA e ENAA.

\begin{tabular}{|c|c|c|c|c|}
\hline Fo & & Parâmetro & Tipo & Distribuição \\
\hline \multirow{4}{*}{ Massa da amostra } & \multirow{4}{*}{ Balança } & Repetitividade & A & Normal \\
\hline & & Resolução & $\mathrm{B}$ & Retangular \\
\hline & & Calibração & A & Normal \\
\hline & & Excentricidade & B & Retangular \\
\hline \multirow{10}{*}{ Massa do Padrão } & $\begin{array}{c}\text { Concentração } \\
\text { da solução } \\
\text { padrão }\end{array}$ & Produtor & $\mathrm{B}$ & Retangular \\
\hline & \multirow{3}{*}{$\begin{array}{c}\text { Pipeta } \\
5000 \mu \mathrm{L}\end{array}$} & Analista & A & Normal \\
\hline & & Produtor & $\mathrm{B}$ & \multirow{2}{*}{ Retangular } \\
\hline & & $\begin{array}{l}\text { Expansão } \\
\text { térmica }\end{array}$ & B & \\
\hline & \multirow{3}{*}{$\begin{array}{c}\text { Balão } \\
\text { volumétrico } \\
25 \mathrm{~mL}\end{array}$} & Analista & A & Normal \\
\hline & & Produtor & $\mathrm{B}$ & \multirow{2}{*}{ Retangular } \\
\hline & & $\begin{array}{l}\text { Expansão } \\
\text { térmica }\end{array}$ & $\mathrm{B}$ & \\
\hline & \multirow{3}{*}{$\begin{array}{l}\text { Pipeta } \\
50 \mu \mathrm{L}\end{array}$} & Analista & $\mathrm{A}$ & Normal \\
\hline & & Produtor & B & \multirow{2}{*}{ Retangular } \\
\hline & & $\begin{array}{l}\text { Expansão } \\
\text { térmica }\end{array}$ & B & \\
\hline $\begin{array}{c}\text { Atividade da } \\
\text { amostra e do } \\
\text { padrão }\end{array}$ & $\begin{array}{c}\text { Espectroscopia } \\
\text { gama }\end{array}$ & $\begin{array}{c}\text { Estatística de } \\
\text { contagem }\end{array}$ & B & Poisson \\
\hline \multirow{3}{*}{$\begin{array}{c}\text { Correção do } \\
\text { decaimento } \\
\text { da amostra e } \\
\text { do padrão }\end{array}$} & $\begin{array}{l}\text { Meia-vida } \\
{ }^{239} \mathrm{U}\end{array}$ & \multirow{3}{*}{$\begin{array}{l}\text { Constante de } \\
\text { decaimento }\end{array}$} & B & \multirow[t]{3}{*}{ Retangular } \\
\hline & Meia-vida & & & \\
\hline & ${ }^{239} \mathrm{~Np}$ & & & \\
\hline
\end{tabular}




\section{RESULTADOS E DISCUSSÃO}

\subsection{Resultado da verificação da calibração do pipetador}

Na verificação do pipetador Eppendorf para a capacidade de $50 \mu \mathrm{L}$ foram obtidos valores de desvio padrão relativo (DPR) e erro relativo (ER) iguais a $0,19 \%$ e $0,32 \%$, respectivamente. Este pipetador foi utilizado para o preparo do padrão sintético de urânio. Os valores apresentados no catálogo do pipetador para estas variáveis são de $1 \%$ para ER e $\leq 0,3 \%$ para DPR. Esses resultados estão apresentados na Tabela 7.

Tabela 7 - Resultados obtidos na verificação da calibração do pipetador automático.

\begin{tabular}{ccc}
\hline Variáveis & Volume obtido & Volume do catálogo \\
\hline $\bar{V} \pm \mathrm{DP}, \mu \mathrm{L}$ & $49,96 \pm 0,96(\mathrm{n}=10)$ & $50 \pm 0,15$ \\
$\mathrm{DPR}, \%$ & 0,19 & $\leq 0,30$ \\
$\mathrm{ER}, \%$ & 0,32 & $\pm 1,00$ \\
\hline
\end{tabular}

$\bar{V}$ - Média aritmética do volume; DP - Desvio padrão; DPR - Desvio padrão relativo; ER Erro relativo; n - Número de determinações.

Fonte: Autora da dissertação.

Ao se comparar os resultados obtidos com os valores presentes no catálogo do pipetador, conclui-se que o volume médio calibrado está dentro da faixa de variação indicada pelo fabricante.

\subsection{Ensaios preliminares}

\subsubsection{Determinação de urânio como impureza em envelopes de polietileno usados na irradiação de amostras e padrões}

Como as amostras são irradiadas em envelopes de polietileno que não são removidos para as contagens, foram feitas determinações de $U$ para verificar a presença deste elemento nesse material. Como o U não foi detectado nos envelopes de polietileno, foram calculados os limites de detecção e de quantificação de U nesses envelopes. Estes resultados estão apresentados na Tabela 8.

De acordo com os resultados de limites de detecção obtidos nos invólucros de polietileno, a fração mássica de $U$ deve ser menor ou igual a $152 \mathrm{ng} \mathrm{g}^{-1}$, considerando que a técnica ENAA de longa duração apresentou o menor valor de limite de detecção para o pico de $277,60 \mathrm{keV}$ do ${ }^{239} \mathrm{~Np}$. Dessa maneira, a contribuição de U advinda do invólucro de polietileno na quantificação de U foi considerada desprezível. 
Tabela 8 - Limites de detecção (LD) e de quantificação (LQ) de $U\left(\mathrm{ng} \mathrm{g}^{-1}\right)$ nos envelopes de polietileno por ENAA de curta e longa duração.

\begin{tabular}{ccccc}
\hline Elemento & $\begin{array}{c}\text { Tipo de } \\
\text { irradiação }\end{array}$ & $\begin{array}{c}\text { Energia dos } \\
\text { raios gama, } \\
\text { keV }\end{array}$ & LD, $\mathbf{n g ~ g}^{-1}$ & LQ, ng g \\
\hline \multirow{2}{*}{$\mathrm{U}$} & Longa duração & 106,12 & 204 & 619 \\
& & 277,60 & 152 & 462 \\
\cline { 2 - 5 } & Curta duração & 74,66 & 1150 & 3495 \\
\hline
\end{tabular}

Fonte: Autora da dissertação.

\subsubsection{Determinação de urânio como impureza na tira de papel de filtro usado como suporte para irradiação do padrão sintético}

As tiras de papel de filtro Whatman $\mathrm{N}^{o} 40$ foram utilizadas como suporte na irradiação do padrão sintético de U, desta maneira, foram feitas determinações para verificar a presença deste elemento nesse material. Também não foi detectado U na tira de papel de filtro, logo, foram calculados os limites de detecção e de quantificação de U, cujos resultados estão apresentados na Tabela 9.

Tabela 9 - Limites de detecção (LD) e de quantificação (LQ) de $U\left(\mathrm{ng} \mathrm{g}^{-1}\right)$ no papel de filtro Whatman $\mathrm{N}^{o} 40$ por ENAA de curta e longa duração.

\begin{tabular}{ccccc}
\hline Elemento & $\begin{array}{c}\text { Tipo da } \\
\text { irradiação }\end{array}$ & $\begin{array}{c}\text { Energia dos } \\
\text { raios gama, } \\
\text { keV }\end{array}$ & LD, ng g & LQ, ng g \\
& \multirow{2}{*}{ Longa duração } & 106,12 & 70 & 212 \\
\hline \multirow{2}{*}{$\mathrm{U}$} & 277,60 & 50 & 153 \\
\cline { 2 - 5 } & Curta duração & 74,66 & 461 & 1400 \\
\hline
\end{tabular}

Fonte: Autora da dissertação.

Em relação aos resultados da determinação de U na tira de papel de filtro Whatman $\mathrm{N}^{o} 40$, a fração mássica deste elemento é menor ou igual a $50 \mathrm{ng} \mathrm{g}^{-1}$, conforme resultado da ENAA de longa duração obtido com o pico de 277,60 keV do ${ }^{239} \mathrm{~Np}$. Deste modo, a contribuição do U advinda do papel de filtro foi considerada desprezível nas análises. 


\subsection{Resultados da quantificação dos componentes da incerteza da determinação de urânio pela análise por ativação com nêutrons}

$\mathrm{Na}$ análise por ativação com nêutrons as principais fontes de incerteza são: preparação da amostra e do padrão, irradiação e medição por espectrometria gama. O cálculo da incerteza combinada consiste na aplicação dos valores das grandezas de entrada, como as incertezas da massa do elemento no padrão $\left(\mathrm{u}_{m_{p}}\right)$, da massa da amostra $\left(\mathrm{u}_{M_{a}}\right)$, das taxas de contagens $\left(\mathrm{u}_{A_{a}}\right.$ e $\left.\mathrm{u}_{A_{p}}\right)$ e da constante de decaimento $\left(\mathrm{u}_{\lambda}\right)$ na equação 14 do cálculo da fração mássica de um elemento pelo método comparativo de NAA.

Os valores das grandezas de entrada usados no cálculo da incerteza são apresentados em tabelas e as porcentagens de contribuição das incertezas padrão combinadas das fontes de incerteza são apresentadas em gráficos, com o intuito de fazer uma comparação entre as incertezas obtidas pelos diferentes procedimentos utilizados.

A incerteza foi calculada para todas as amostras e MRCs analisados neste trabalho e foi apresentada junto aos resultados. Nesta seção, os dados apresentados são de uma amostra de casca de árvore para as incertezas obtidas por ENAA de curta duração, INAA de longa duração e ENAA de longa duração. Como a técnica INAA de curta duração não possibilitou a determinação de $U$ em nenhuma das amostras, a sua incerteza não foi estimada.

\subsubsection{Incerteza padrão combinada da massa da amostra de casca de árvore}

Para o cálculo da incerteza padrão combinada na massa da amostra, foram consideradas as seguintes grandezas de entrada: repetibilidade, resolução, calibração e excentricidade. Esses valores foram obtidos do certificado de calibração da balança e estão apresentados na Tabela 10.

Tabela 10 - Valores das contribuições da incerteza padrão combinada da massa da amostra.

\begin{tabular}{cccc}
\hline Contribuição & Incerteza, g & Fator & $\begin{array}{c}\text { Incerteza } \\
\text { combinada, } \mathbf{g}\end{array}$ \\
\cline { 1 - 3 } Repetibilidade & $2 \times 10^{-5}$ & 1 & \\
\cline { 1 - 3 } Resolução & $1 \times 10^{-5}$ & $1 / 2 \sqrt{3}$ & \\
\hline Calibração & $1 \times 10^{-5}$ & $1 / k(\mathrm{k}=2)$ & \\
\hline Excentricidade & $2 \times 10^{-5}$ & $1 / 2 \sqrt{3}$ & \\
\hline
\end{tabular}

k - Fator de abrangência da incerteza expandida.

Fonte: Autora da dissertação.

Considerando que foi usada a mesma balança na pesagem de todas as amostras, o valor da incerteza padrão combinada da massa da amostra é o mesmo em todos os cálculos 
de incerteza. Na Figura 14, são apresentadas as porcentagens das contribuições da incerteza padrão combinada da massa da amostra para cada procedimento.

Figura 14 - Porcentagem da contribuição da incerteza padrão combinada da massa da amostra de casca de árvore por procedimento utilizado.

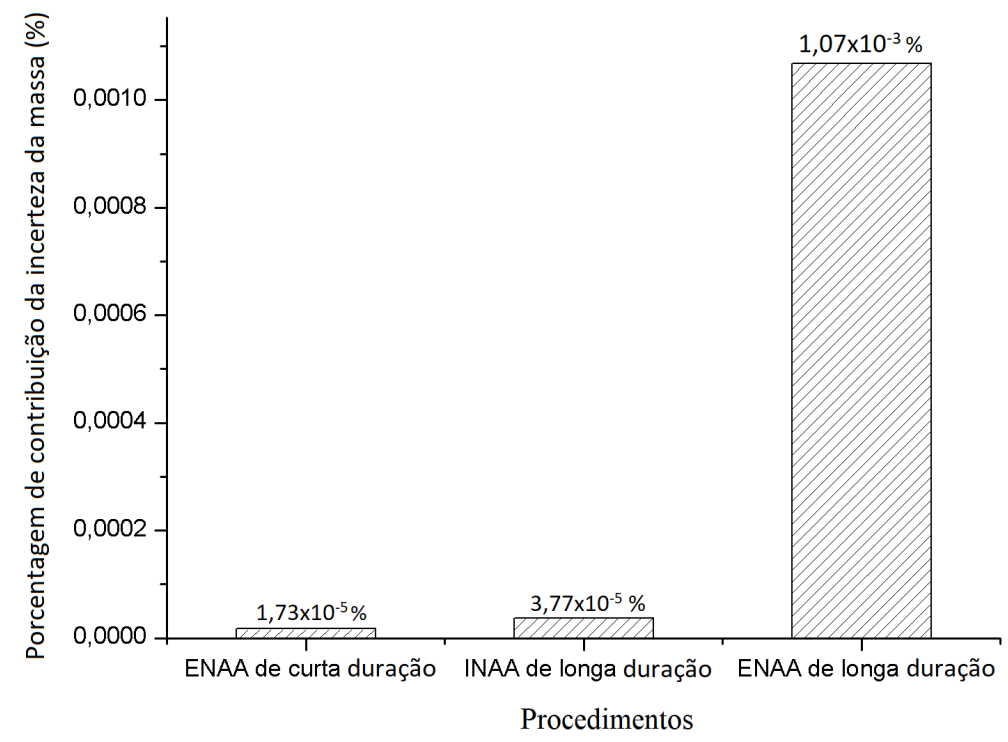

Fonte: Autora da dissertação.

A Figura 14 mostra que a contribuição da incerteza da massa da amostra em relação ao valor da incerteza total é mais relevante na ENAA de longa duração do que nos demais procedimentos. Isso acontece, pois, com a diminuição da contribuição dos outros parâmetros, a parcela correspondente a incerteza da massa aumenta. Também é importante ressaltar que a porcentagem de contribuição da incerteza padrão combinada da massa da amostra é pequena, da ordem de $10^{-3}$ para ENAA de longa duração e $10^{-5}$ para ENAA de curta duração e INAA de longa duração.

\subsubsection{Incerteza padrão combinada da massa do elemento no padrão sintético de $U$}

A incerteza combinada da massa do padrão sintético de $U$ foi calculada levando em consideração diversas contribuições, como a incerteza da solução padrão estoque, a diluição dessa solução e o processo de preparo do padrão sintético.

O valor da incerteza da concentração da solução padrão estoque de U foi fornecido pelo produtor no certificado que acompanha este material. Com relação à diluição da solução padrão, foi considerada a incerteza do balão volumétrico, fornecida pelo fabricante, a repetibilidade, obtida pela calibração prévia desta vidraria, e a expansão térmica da água. Ainda na diluição da solução padrão, foi utilizado pipetador automático, cuja incerteza de 
repetibilidade foi obtida na sua verificação da calibração por meio do desvio padrão, além do valor da incerteza do produtor.

Para o preparo do padrão sintético de U, a solução padrão diluída foi pipetada $(50 \mu \mathrm{L})$ em tiras de papel de filtro. Dessa maneira, foram consideradas novamente as incertezas do pipetador automático, sendo elas a incerteza de repetibilidade advinda da verificação da calibração, a imprecisão do volume pipetado fornecida pelo produtor e a expansão térmica da água. Os valores das grandezas de entrada na incerteza da massa do padrão estão apresentados na Tabela 11.

Tabela 11 - Valores das contribuições da incerteza padrão combinada da massa do elemento no padrão.

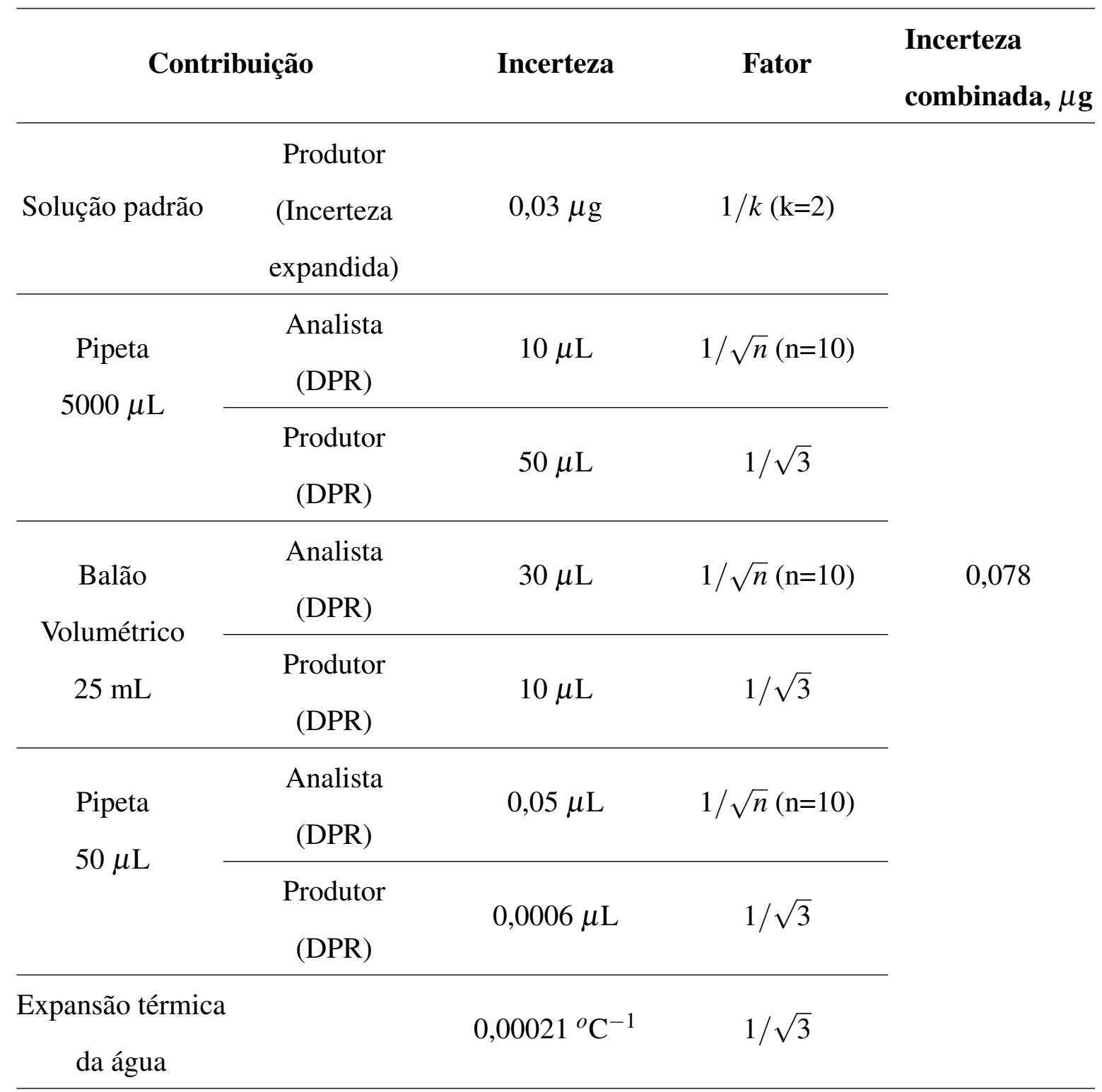

DPR - Desvio padrão relativo; $\mathrm{n}$ - Número de repetições; $\mathrm{k}=$ Fator de abrangência da incerteza expandida.

Fonte: Autora da dissertação. 
Como os padrões sintéticos de $\mathrm{U}$ usados neste trabalho foram obtidos da mesma maneira, o valor da incerteza combinada da massa do padrão foi igual para todos os procedimentos analíticos. Na Figura 15, são apresentadas as porcentagens das contribuições da incerteza padrão combinada da massa do padrão para cada procedimento usado neste trabalho. A contribuição da incerteza da massa do padrão para a ENAA de longa duração foi significativa, chegando a $26,56 \%$ do valor da incerteza total associada à fração mássica. Já nos demais procedimentos, as contribuições desta fonte de incerteza foram menos relevantes, inferiores a $0,87 \%$. Isso acontece porque, com a ENAA de longa duração, as contribuições dos outros parâmetros foram reduzidas e a parcela da incerteza da massa do elemento no padrão aumenta.

Figura 15 - Porcentagem da contribuição da incerteza padrão combinada da massa do elemento no padrão por procedimento utilizado.

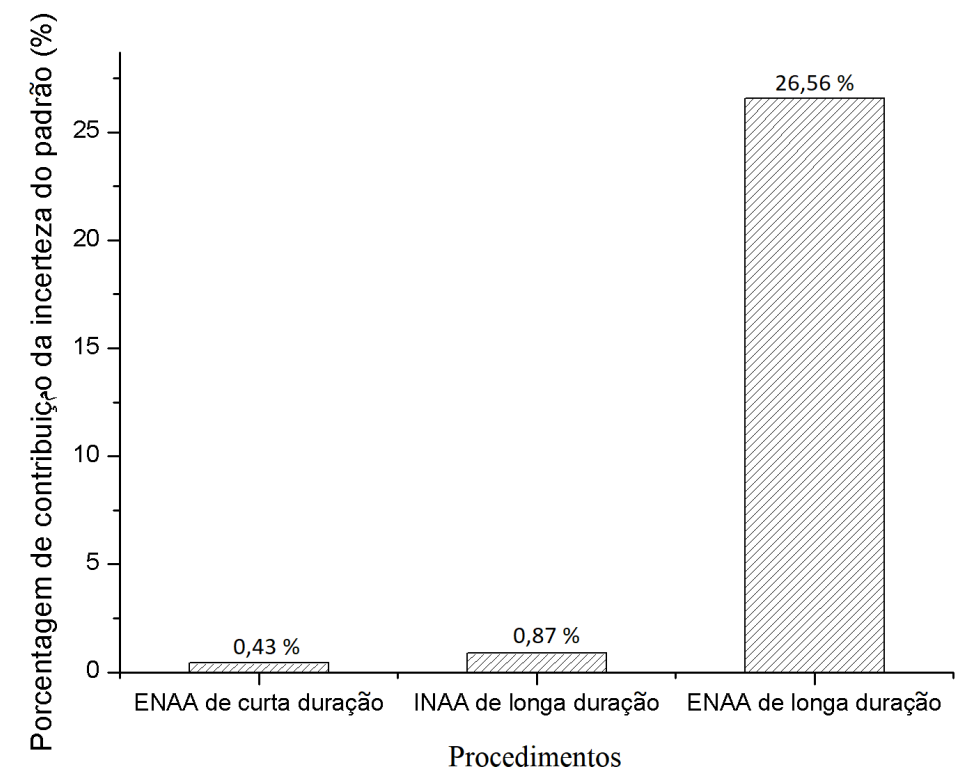

Fonte: Autora da dissertação.

\subsubsection{Incerteza da constante de decaimento}

A contribuição da incerteza da constante de decaimento decorre da incerteza da meia-vida dos radionuclídeos estudados, no caso, o ${ }^{239} \mathrm{U}$ e o ${ }^{239} \mathrm{~Np}$. Esses valores foram consultados em LBNL (2018). A incerteza da constante de decaimento do ${ }^{239} \mathrm{U}$ foi aplicada na ENAA de curta duração e a do ${ }^{239} \mathrm{~Np}$ nos procedimentos de longa duração. Os valores da incerteza padrão das constantes de decaimento estão na Tabela 12, enquanto que as porcentagens de contribuição da incerteza da constante de decaimento são apresentadas na Figura 16. Em todos procedimentos, a contribuição da incerteza das constantes de decaimento na incerteza padrão combinada da fração mássica é pequena, da ordem de $10^{-5}$. 
Tabela 12 - Valores das incertezas padrão das constantes de decaimento.

\begin{tabular}{|c|c|c|c|}
\hline Contribuição & Incerteza, min $^{-1}$ & Fator & $\begin{array}{c}\text { Incerteza } \\
\text { padrão, } \text { min }^{-1}\end{array}$ \\
\hline${ }^{239} \mathrm{U}$ & $6,29 \times 10^{-6}$ & \multirow{2}{*}{$1 / \sqrt{3}$} & $3,64 \times 10^{-6}$ \\
\hline${ }^{239} \mathrm{~Np}$ & $2,60 \times 10^{-8}$ & & $1,50 \times 10^{-8}$ \\
\hline
\end{tabular}

Fonte: Autora da dissertação.

Figura 16 - Porcentagem da contribuição da incerteza padrão das constantes de decaimento por procedimento utilizado.

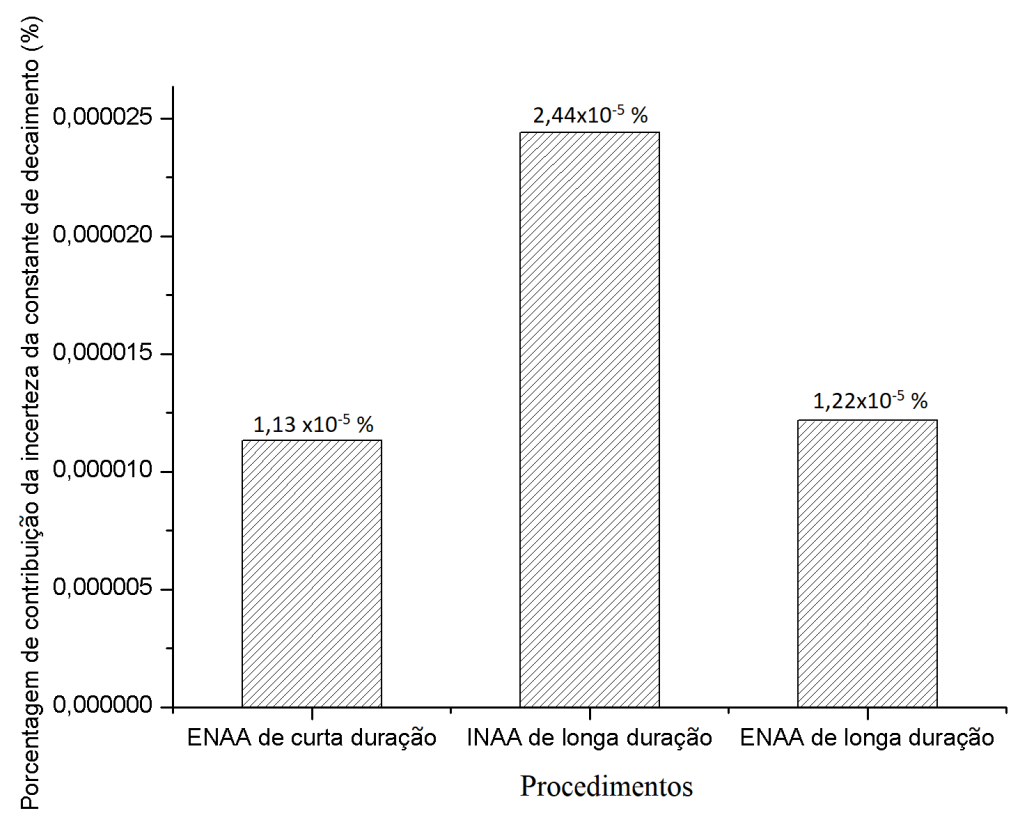

Fonte: Autora da dissertação.

\subsubsection{Incerteza padrão combinada da atividade da amostra de casca de árvore e do padrão de $U$}

A incerteza associada à atividade da amostra e do padrão é composta por diferentes componentes de incerteza relativas ao processo de irradiação e medida por espectrometria gama. Com relação ao processo de irradiação, podem ser consideradas como fontes de incertezas as diferenças na geometria de irradiação, as reações nucleares de interferência, além de processos como a auto absorção e o espalhamento de nêutrons. Quanto à espectrometria gama, as contribuições à incerteza são devidas à estatística de contagem, à auto absorção de raios gama, às diferenças na geometria de contagem, às interferências de raios gama, às perdas por empilhamentos de picos e aos efeitos do tempo morto (KUČERA et al., 2000; KUČERA et al., 2004; MOREIRA et al., 2005; MOREIRA et al., 2006). De acordo com NRC (2001) e Moreira et al. (2006), dentre as fontes de incertezas citadas, a estatística de contagem 
é a que apresenta a contribuição mais relevante para as incertezas da amostra e do padrão. Desta maneira, neste trabalho considerou-se apenas a estatística de contagem no cálculo da incerteza da atividade da amostra e do padrão. Nas Figuras 17 e 18, estão apresentadas as contribuições, em porcentagem, da incerteza da atividade de uma amostra de casca de árvore e do padrão em cada procedimento analítico, respectivamente. A porcentagem de contribuição da atividade da amostra, devido à estatística de contagem, é superior a 99\% para ENAA de curta duração e INAA de longa duração. O uso de nêutrons epitérmicos na irradiação de longa duração reduz a atividade de interferentes comuns em matrizes biológicas. Esse fato acarreta na medição de amostras com atividades menores e, por conseguinte, na redução dos erros associados a essa medida (estatística de contagem), tornando a incerteza da atividade da amostra obtida por ENAA de longa duração a menor dentre os procedimentos estudados. Por outro lado, a porcentagem de contribuição da incerteza da atividade do padrão é menor do que a da amostra, conforme a Figura 18. Isso ocorre pois o padrão sintético de U não apresenta, em sua composição, elementos considerados interferentes, o que resulta na redução dos erros associados a estatística de contagem.

Figura 17 - Porcentagem da contribuição da incerteza padrão da atividade da amostra de casca de árvore por procedimento utilizado.

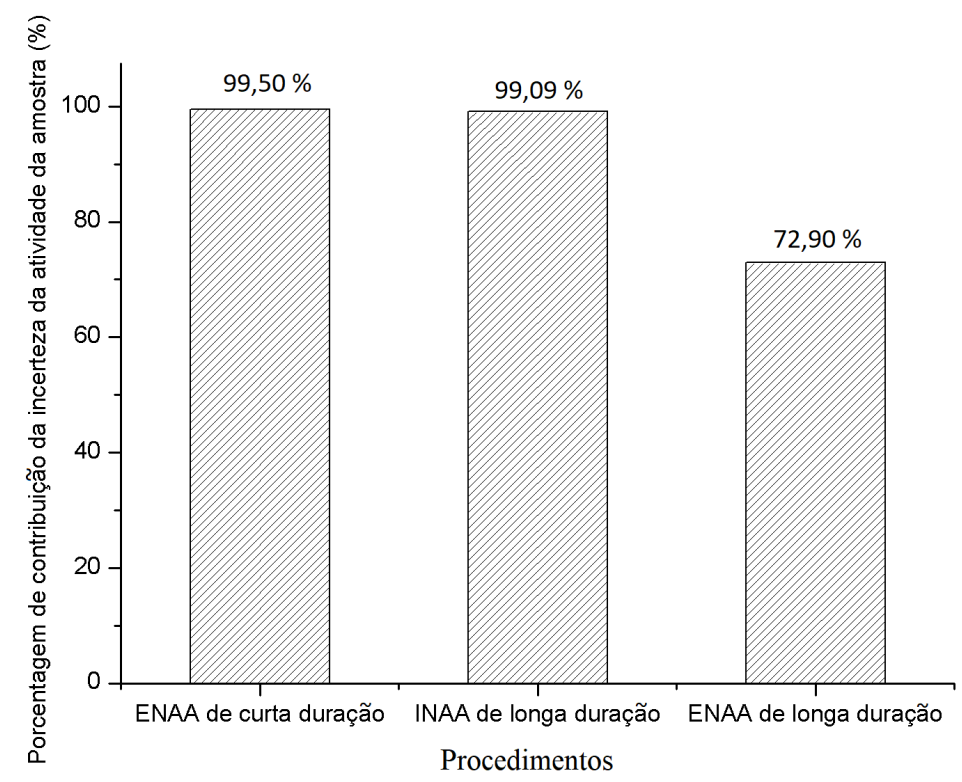

Fonte: Autora da dissertação. 
Figura 18 - Porcentagem da contribuição da incerteza padrão da atividade do padrão por procedimento utilizado.

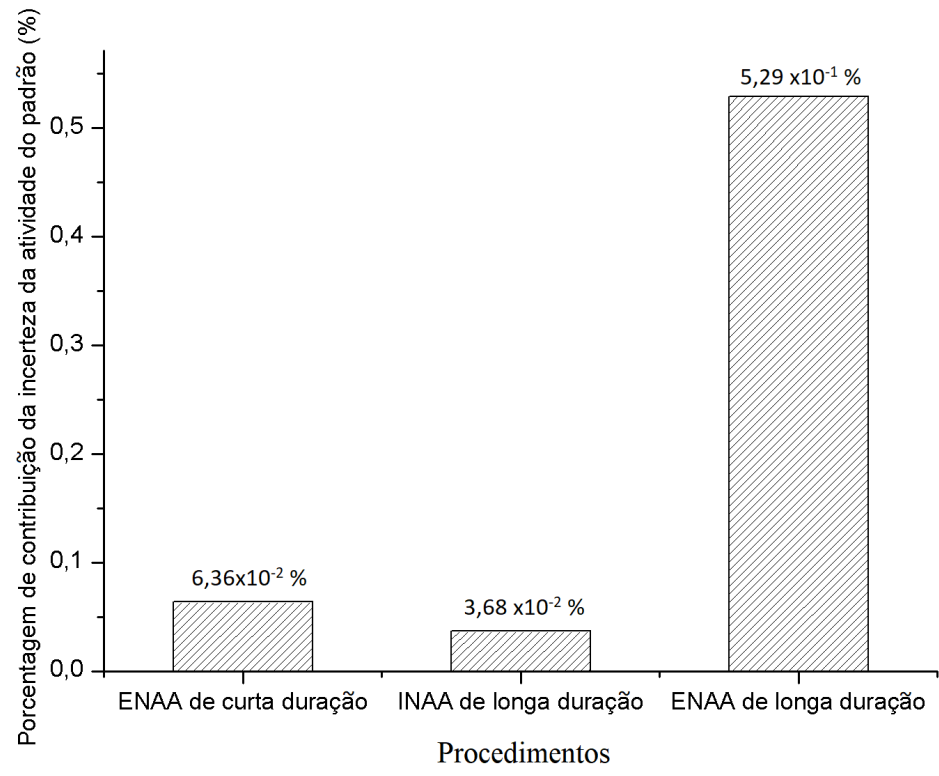

Fonte: Autora da dissertação.

\subsubsection{Comparação entre as incertezas da determinação de urânio em amostra de casca de árvore obtidas por diferentes procedimentos analíticos}

Nas seções anteriores foram apresentadas as contribuições de cada fonte de incerteza no valor da incerteza padrão combinada da determinação de U pelos diferentes procedimentos analíticos utilizados. A incerteza da atividade da amostra foi a parcela que mais contribuiu no valor da incerteza de medição em todos os procedimentos. Dessa maneira, as diferenças entre os valores de incerteza combinada obtidos pelos procedimentos analíticos decorrem dessa fonte de incerteza. Na Figura 19 estão apresentadas as porcentagens da incerteza de medição em relação ao valor da fração mássica de U determinada pelos procedimentos estudados. Esses resultados foram obtidos em uma amostra representativa de casca de árvore. A partir da análise deste gráfico podemos observar que a ENAA de longa duração foi o procedimento que apresentou o menor valor de incerteza de medição, representando 1,9\% do valor da fração mássica. Já a ENAA de curta duração apresentou o maior valor de incerteza dentre os procedimentos aplicados, chegando a 24,3\% do valor da fração mássica, ou seja, a incerteza de medição obtida pela ENAA de curta duração foi cerca de uma ordem de grandeza maior que a obtida pela de longa duração. 
Figura 19 - Porcentagem de incerteza na fração mássica de U determinada por diferentes procedimentos analíticos.

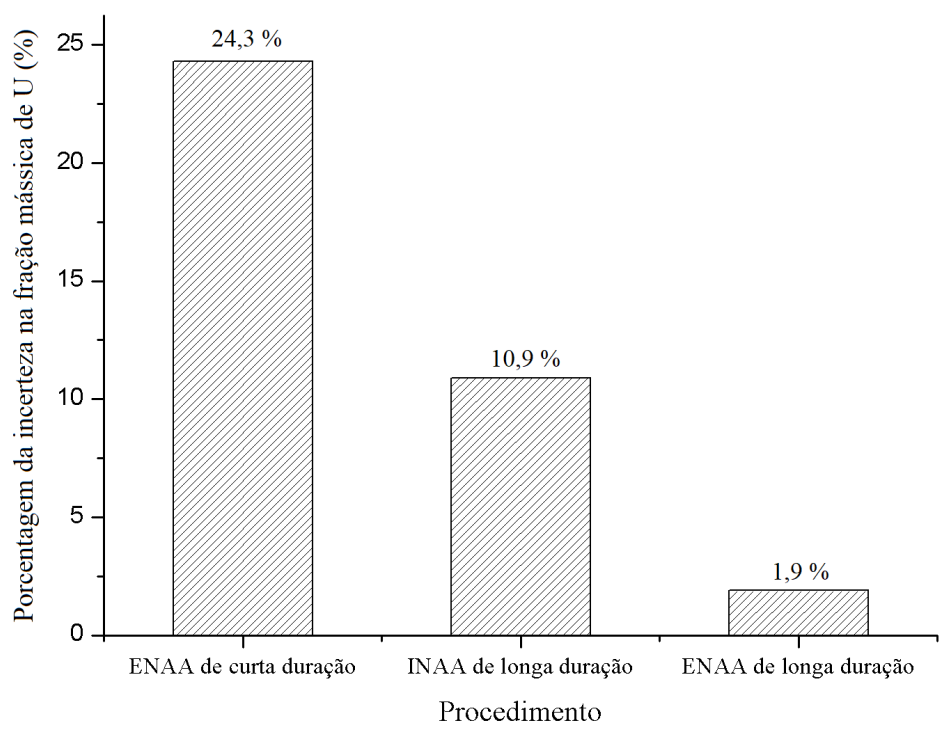

Fonte: Autora da dissertação.

\subsection{Resultados da determinação de urânio em materiais de referência certificados}

Nesta seção são apresentados os resultados das análises dos MRCs juntamente com seus valores certificados. Estes resultados são as médias das frações mássicas (M), as incertezas expandidas (u), os valores de desvio padrão relativo (DPR), os valores de HorRat, os erros relativos (ER), os Z scores e os limites de detecção (LD) e de quantificação (LQ). Neste trabalho, os erros relativos foram também calculados para os MRCs que apresentavam apenas valores informativos em seus certificados, já o Z score não pôde ser calculado nos MRCs cujo valor informativo não possuía incerteza.

Foi realizada a verificação da existência de valores extremos (outliers) nos conjuntos de dados e, para isso, foi aplicado o teste de Grubbs a um nível de significância de 0,05 . Alguns outliers foram detectados e removidos do conjunto de dados. Os resultados individuais obtidos nas determinações de U nos MRCs estão apresentados em Tabelas do Apêndice A desta dissertação.

\subsubsection{Irradiações de curta duração de materiais de referência certificados}

\subsubsection{Análise por ativação com nêutrons térmicos de curta duração}

Na Tabela 13 são apresentados os resultados das médias das frações mássicas e os limites de detecção e quantificação de U em MRCs obtidos por INAA de curta duração. Esses resultados foram determinados usando o pico de $74,66 \mathrm{keV}$ do ${ }^{239} \mathrm{U}$. 
Tabela 13 - Frações mássicas de U (ng g $\left.{ }^{-1}\right)$ em materiais de referência certificados obtidas por INAA de curta duração.

\begin{tabular}{|c|c|c|c|c|c|c|c|c|}
\hline MRC & $\mathbf{M} \pm \mathbf{u}(\mathbf{n})$ & DPR, \% & HorRat & ER, \% & Z score & LD & LQ & Valor do certificado \\
\hline $\begin{array}{l}\text { IAEA - 140/TM } \\
\text { Seaweed }\end{array}$ & $<3090$ & & - & & & 3090 & 9395 & $730(647-813)$ \\
\hline $\begin{array}{l}\text { NIST - } 1575 \\
\text { Pine Needles }\end{array}$ & $<1519$ & & - & & & 1519 & 4617 & $20 \pm 4$ \\
\hline $\begin{array}{c}\text { NIST - 1632d } \\
\text { Trace Elements in Coal }\end{array}$ & $<2490$ & & - & & & 2490 & 7559 & $517 \pm 12$ \\
\hline $\begin{array}{l}\text { NIST - 1633b } \\
\text { Coal Fly Ash }\end{array}$ & $7619 \pm 1539(4)$ & 21,4 & 1,8 & $-13,3$ & $-0,74$ & 3914 & 11947 & $8790 \pm 360$ \\
\hline $\begin{array}{c}\text { INCT - M3 } \\
\text { Herring Tissue }\end{array}$ & $<2074$ & & - & & & 2074 & 5453 & $75,2 \pm 8,2$ \\
\hline $\begin{array}{c}\text { IAEA - SOIL - } 7 \\
\text { Trace Elements in Soil }\end{array}$ & $<4475$ & & - & & & 4475 & 13604 & $2600(2200-3300)$ \\
\hline $\begin{array}{l}\text { NIST - } 1566 b \\
\text { Oyster Tissue }\end{array}$ & $<593$ & & - & & & 593 & 1803 & $255 \pm 1,4^{a}$ \\
\hline $\begin{array}{c}\text { INCT - CTA - VTL - } 2 \\
\text { Virginia Tobacco Leaves }\end{array}$ & $<570$ & & - & & & 570 & 1736 & $163 \pm 8^{a}$ \\
\hline $\begin{array}{c}\text { INCT - OBTL - } 5 \\
\text { Oriental Basma Tobacco Leaves }\end{array}$ & $<822$ & & - & & & 822 & 2501 & $113^{a}$ \\
\hline IPEN - Mexilhão & $<3131$ & & - & & & 3131 & 9518 & $112 \pm 16^{a}$ \\
\hline $\begin{array}{c}\text { IAEA - RLA 2/014 } \\
\text { Volcanic Ashes }\end{array}$ & $7952 \pm 3835(2)$ & 4,6 & 0,4 & $-6,5$ & $-0,14$ & 3423 & 10469 & $8500 \pm 600$ \\
\hline
\end{tabular}

M - Média aritmética; u - Incerteza expandida com k = 2 e nível de significância de 0,05; $\mathrm{n}$ - Número de determinações; DPR - Desvio padrão relativo; ER - Erro relativo; a - Valor informativo. Fonte: Autora da dissertação. 
Dentre os 11 MRCs analisados por este procedimento, apenas dois tiveram suas frações mássicas de U determinadas. As frações mássicas de U dos outros MRCs ficaram abaixo do limite de detecção do procedimento e não puderam ser quantificadas.

Os resultados obtidos para estes dois MRCs, apresentaram erros relativos menores, em módulo, que 13,3\%, que indica a exatidão desses dados. Nas Figuras 20 e 21 estão os valores de $\mathrm{Z}$ score e de HorRat, respectivamente.

Os $\mathrm{Z}$ scores obtidos nestas análises indicam boa exatidão dos resultados, com $\mid Z$ scorel < 2, a um nível de significância de 0,05 em relação aos valores certificados. Os valores de HorRat foram inferiores a 1,8, o que atestou a precisão dos resultados.

Figura 20 - Valores de Z scores para as frações mássicas de U nos materiais de referência certificados obtidos por INAA de curta duração.

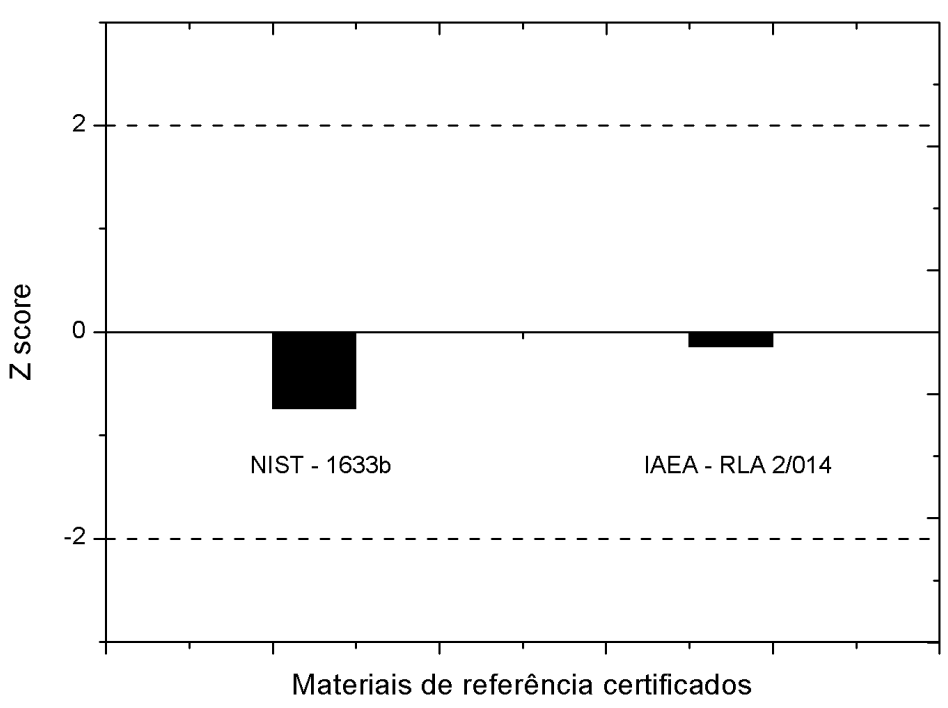

Fonte: Autora da dissertação. 
Figura 21 - Valores de HorRat para as frações mássicas de U nos materiais de referência certificados obtidos por INAA de curta duração.

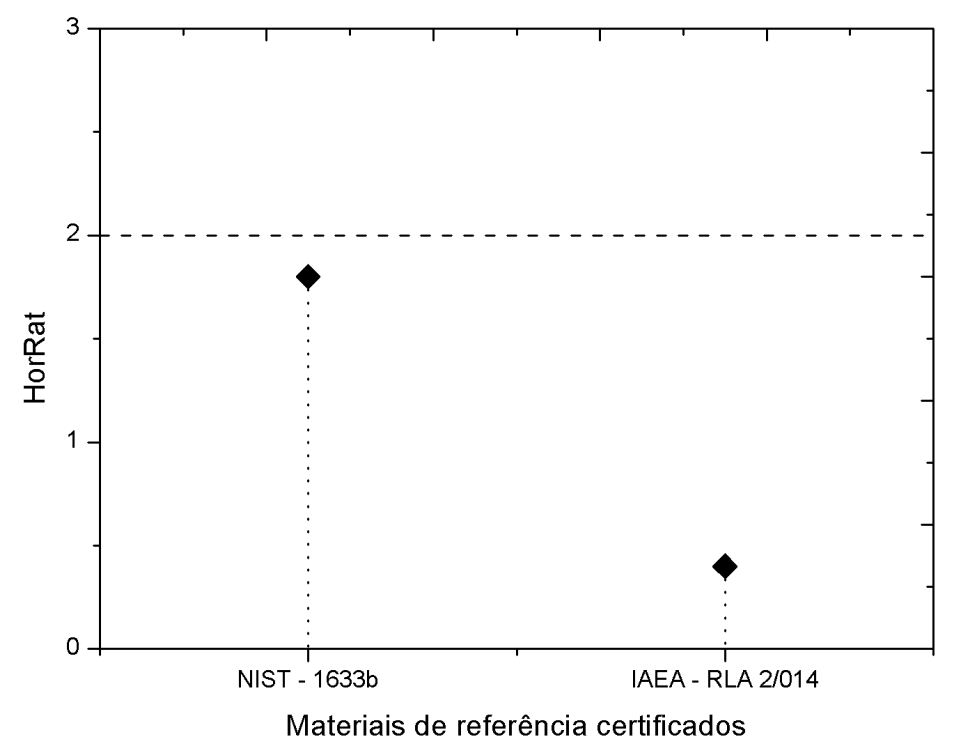

Fonte: Autora da dissertação.

\subsubsection{Análise por ativação com nêutrons epitérmicos de curta duração}

Os resultados das análises das frações mássicas de U nos MRCs por ENAA de curta duração estão apresentados na Tabela 14. As frações mássicas foram obtidas usando o pico de $74,66 \mathrm{keV}$ do ${ }^{239} \mathrm{U}$. Por meio da ENAA de curta duração, foram determinadas as frações mássicas de U em sete dos 11 MRCs estudados.

Por este procedimento foram obtidos limites de detecção e quantificação inferiores aos da INAA de curta duração, o que possibilitou a quantificação de U em um maior número de MRCs. Os valores das incertezas associadas às frações mássicas de U também foram menores com o uso de nêutrons epitérmicos. Isto está relacionado à ativação com nêutrons térmicos ocasionar um aumento da radiação de fundo, o que prejudica a resolução dos picos que compõem o espectro. Os resultados da ENAA apresentaram erros relativos inferiores a $7,1 \%$. Para melhor visualização, os Z scores e os valores de HorRat estão apresentados nas Figuras 22 e 23, respectivamente.

Os Z scores obtidos nos resultados das análises ficaram, em módulo, abaixo de 0,43, de modo a apontar a exatidão dos resultados a um nível de significância de 0,05 em relação aos valores certificados. Já os valores de HorRat foram menores do que 1,6, atestando a reprodutibilidade do conjunto de dados. 
Tabela 14 - Frações mássicas de U (ng g ${ }^{-1}$ ) em materiais de referência certificados obtidas por ENAA de curta duração.

\begin{tabular}{|c|c|c|c|c|c|c|c|c|}
\hline MRC & $\mathbf{M} \pm \mathbf{u}(\mathbf{n})$ & DPR, \% & HorRat & ER, \% & $Z$ score & LD & LQ & Valor do certificado \\
\hline $\begin{array}{l}\text { IAEA - 140/TM } \\
\text { Seaweed }\end{array}$ & $720 \pm 288(8)$ & 26,6 & 1,6 & $-1,4$ & $-0,03$ & 218 & 662 & $730(647-813)$ \\
\hline $\begin{array}{l}\text { NIST - } 1575 \\
\text { Pine Needles }\end{array}$ & $<252$ & & - & & & 252 & 767 & $20 \pm 4$ \\
\hline $\begin{array}{c}\text { NIST - 1632d } \\
\text { Trace Elements in Coal }\end{array}$ & $534 \pm 113(6)$ & 11,9 & 0,7 & 3,2 & 0,15 & 115 & 350 & $517 \pm 12$ \\
\hline $\begin{array}{l}\text { NIST - 1633b } \\
\text { Coal Fly Ash }\end{array}$ & $8836 \pm 458(7)$ & 6,9 & 0,6 & 0,53 & 0,08 & 329 & 986 & $8790 \pm 360$ \\
\hline $\begin{array}{c}\text { INCT - M3 } \\
\text { Herring Tissue }\end{array}$ & $<390$ & & - & & & 390 & 1187 & $75,2 \pm 8,2$ \\
\hline $\begin{array}{c}\text { IAEA - SOIL - } 7 \\
\text { Trace Elements in Soil }\end{array}$ & $2585 \pm 451$ & 6,0 & 1,5 & $-0,6$ & $-0,02$ & 699 & 1638 & $2600(2200-3300)$ \\
\hline $\begin{array}{l}\text { NIST - } 1566 b \\
\text { Oyster Tissue }\end{array}$ & $257 \pm 81$ & 8,3 & 0,4 & 0,8 & 0,03 & 75 & 226 & $255 \pm 1,4^{a}$ \\
\hline $\begin{array}{c}\text { INCT - CTA - VTL - } 2 \\
\text { Virginia Tobacco Leaves }\end{array}$ & $151 \pm 88(3)$ & 17,5 & 0,8 & $-7,1$ & $-0,13$ & 85 & 260 & $163 \pm 8^{a}$ \\
\hline $\begin{array}{c}\text { INCT - OBTL - } 5 \\
\text { Oriental Basma Tobacco Leaves }\end{array}$ & $<453$ & & - & & & 453 & 1376 & $113^{a}$ \\
\hline IPEN - Mexilhão & $<456$ & & - & & & 456 & 1386 & $112 \pm 16^{a}$ \\
\hline $\begin{array}{c}\text { IAEA - RLA 2/014 } \\
\text { Volcanic Ashes }\end{array}$ & $8204 \pm 328(6)$ & 12,2 & 1,5 & $-3,5$ & $-0,43$ & 336 & 1048 & $8500 \pm 600$ \\
\hline
\end{tabular}

M - Média aritmética; $\mathrm{u}$ - Incerteza expandida com k = 2 e nível de significância de 0,05; $\mathrm{n}$ - Número de determinações; DPR - Desvio padrão relativo; ER - Erro relativo; a - Valor informativo. Fonte: Autora da dissertação. 
Figura 22 - Valores de Z score para as frações mássicas de U nos materiais de referência certificados obtidos por ENAA de curta duração.

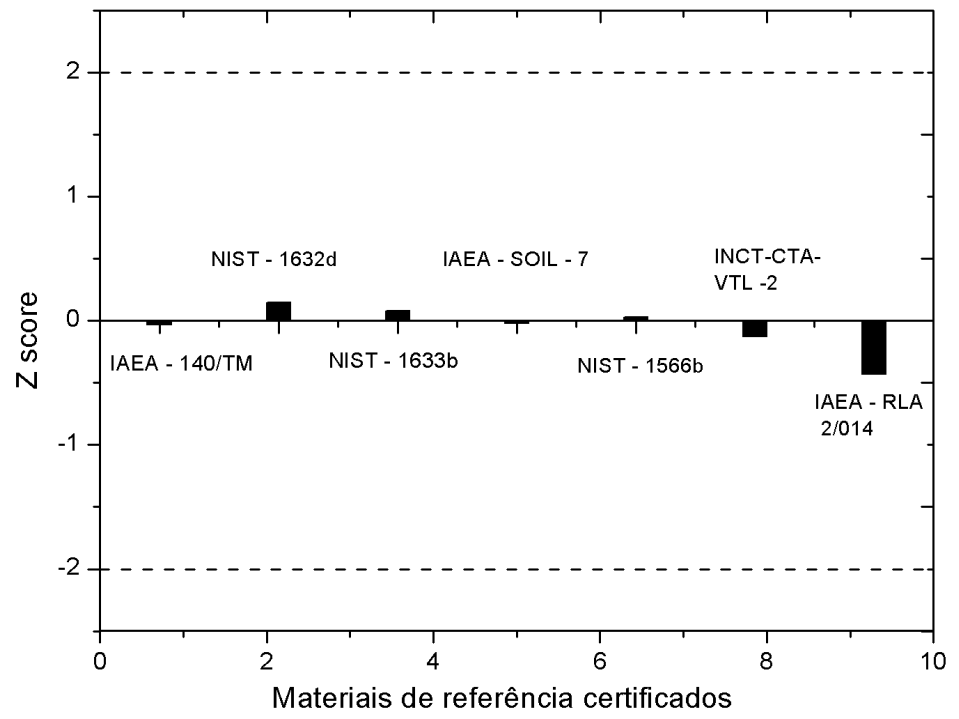

Fonte: Autora da dissertação.

Figura 23 - Valores de HorRat para as frações mássicas de U nos materiais de referência certificados obtidos por ENAA de curta duração.

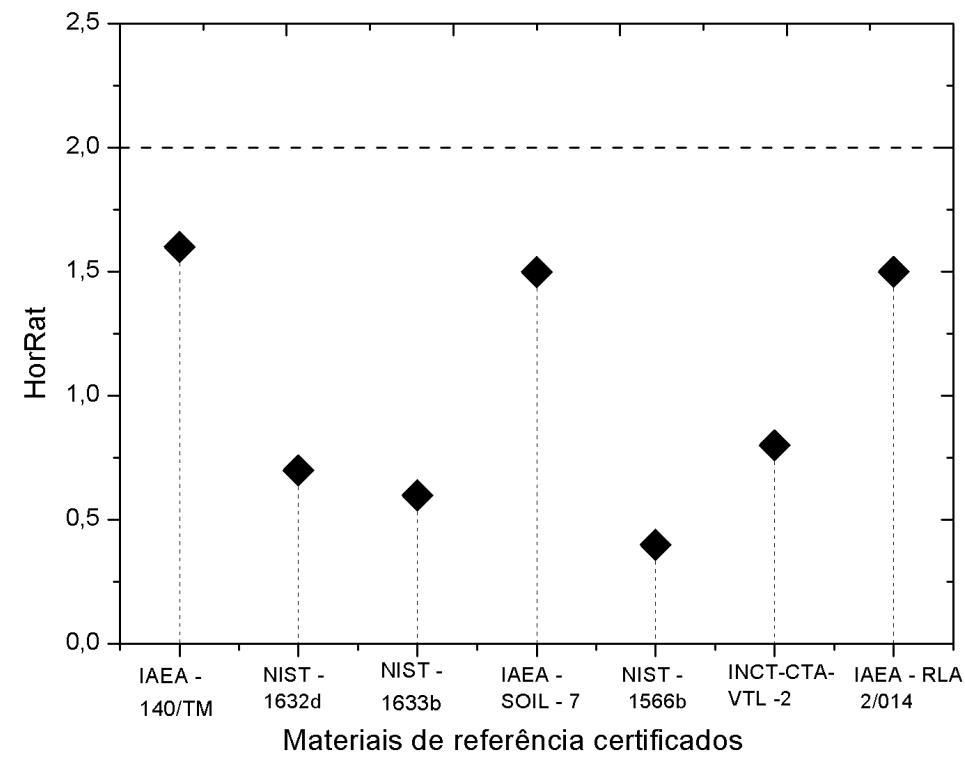

Fonte: Autora da dissertação. 


\subsubsection{Irradiações de longa duração de materiais de referência}

\subsubsection{Análise por ativação com nêutrons térmicos de longa duração}

Estão apresentadas na Tabela 15 as médias das frações mássicas de U determinadas nos MRCs por meio da INAA de longa duração. Esses resultados foram obtidos usando os picos de $106,12 \mathrm{keV}$ e $277,60 \mathrm{keV}$ do ${ }^{239} \mathrm{~Np}$ para dois tempos de decaimento diferentes. Os valores calculados de Z score e de HorRat estão dispostos nas Figuras de 24 a 27. Por meio deste procedimento, oito dos 11 MRCs tiveram suas frações mássicas de U quantificadas, e seus limites de detecção foram, em geral, inferiores aos obtidos com INAA e ENAA de curta duração. As incertezas associadas às frações mássicas também foram menores do que as obtidas nas irradiações térmica e epitérmica de curta duração.

Nos MRCs IAEA - 140/TM Seaweed, NIST - 1632d Trace Elements in Coal, NIST - 1633b Coal Fly Ash, IAEA - SOIL - 7 Trace Elements in Soil e IAEA - RLA 2/014 Volcanic Ashes as frações mássicas de U foram determinadas pela medição das taxas de contagens do pico de $277,60 \mathrm{keV}$ do ${ }^{239} \mathrm{~Np}$. Nestes materiais, o pico de $106,12 \mathrm{keV}$ do ${ }^{239} \mathrm{~Np}$ não foi detectado devido ao problema de interferência espectral do ${ }^{153} \mathrm{Sm}$. A presença de $\mathrm{Sm}$ nesses MRCs foi confirmada em seus respectivos certificados, além do fato deste elemento também ser formado pela fissão do ${ }^{235} \mathrm{U}$. Na irradiação térmica de longa duração, esses MRCs apresentaram espectros de raios gama complexos nas regiões de baixa energia. Convêm ressaltar que o MRC INCT Virgínia Tobacco Leaves foi o único material no qual foi possível quantificar U pelos picos de 277,60 e 106,12 keV. O espectro obtido na análise do MRC IAEA - SOIL - 7 pela INAA de longa duração, pode ser visto na Figura 28. Neste espectro, a atividade do pico de $103,18 \mathrm{keV}$ do ${ }^{153} \mathrm{Sm}$ é maior que a do pico de $106,12 \mathrm{keV}$ do ${ }^{239} \mathrm{~Np}$, o que indica dificuldade na resolução do pico pelo sistema, acarretando erros na quantificação da fração mássica de U por este pico.

Nos MRCs NIST - 1566b Oyster Tissue e INCT - OBTL - 5 Oriental Basma Tobacco Leaves, o U não foi determinado pelo pico de $277,60 \mathrm{keV}$ do ${ }^{239} \mathrm{~Np}$ devido ao problema de interferência espectral, além disso, esse pico se encontra em uma região complexa do espectro. A Figura 29 apresenta o espectro obtido da análise do MRC INCT - OBTL - 5 Oriental Basma Tobacco Leaves pela INAA de longa duração, cujo pico de 277,60 keV do ${ }^{239} \mathrm{~Np}$ aparece acompanhado do pico de $273 \mathrm{keV}$ com alta atividade. Isso gerou problemas na resolução do pico de interesse e prejudicou a quantificação de U. Essa dificuldade pode ser justificada por se tratar de uma região do espectro caracterizada por emissões de radionuclídeos como o ${ }^{203} \mathrm{Hg}$ e o ${ }^{75} \mathrm{Se}$, que possuem picos próximos ao $277,60 \mathrm{keV}$ do ${ }^{239} \mathrm{~Np}$.

Os resultados obtidos com 7 dias de decaimento foram considerados, em geral, exatos e precisos, com Z scores menores que 1,9 e DPRs variando de 3,9\% a 19,4\%, e valores de HorRat menores que 2. 
Tabela 15 - Frações mássicas de U (ng g ${ }^{-1}$ ) em materiais de referência certificados obtidas por INAA de longa duração.

\begin{tabular}{|c|c|c|c|c|c|c|c|c|c|c|c|c|c|c|}
\hline \multirow{2}{*}{ MRC } & \multirow{2}{*}{$\begin{array}{c}\text { Energia dos } \\
\text { raios gama }(\mathrm{keV})\end{array}$} & \multicolumn{5}{|c|}{$t_{d}=7 \mathrm{~d}$} & \multicolumn{5}{|c|}{$t_{d}=9 \mathrm{~d}$} & \multirow{2}{*}{ LD } & \multirow{2}{*}{ LQ } & \multirow{2}{*}{ Valor do certificado } \\
\hline & & $\mathbf{M} \pm \mathbf{u}(\mathbf{n})$ & DPR, \% & HorRat & ER, \% & $\mathbf{Z}$ score & $\mathbf{M} \pm \mathbf{u}(\mathbf{n})$ & DPR, \% & HorRat & ER, \% & Z score & & & \\
\hline IAEA - 140/TM & 106,12 & $*$ & \multicolumn{4}{|c|}{-} & $*$ & \multicolumn{4}{|c|}{-} & 47 & 142 & \multirow{2}{*}{$730(647-813)$} \\
\hline Seaweed & 277,60 & $651 \pm 135(2)$ & 3,9 & 0,2 & $-10,8$ & $-0,5$ & $534 \pm 63(4)$ & 15,1 & 0,8 & $-26,9$ & $-1,8$ & 112 & 340 & \\
\hline NIST - 1575 & 106,12 & $<99$ & \multirow{2}{*}{\multicolumn{4}{|c|}{$\begin{array}{l}- \\
-\end{array}$}} & & \multicolumn{4}{|c|}{-} & 99 & 301 & \multirow{2}{*}{$20 \pm 4$} \\
\hline Pine Needles & 277,60 & $<107$ & & & & & & & - & & & 107 & 323 & \\
\hline NIST - 1632d & 106,12 & $*$ & \multicolumn{4}{|c|}{-} & $*$ & \multicolumn{4}{|c|}{-} & 63 & 218 & \multirow{2}{*}{$517 \pm 12$} \\
\hline Trace Elements in Coal & 277,60 & $442 \pm 61(4)$ & 10,8 & 0,8 & $-14,5$ & $-1,2$ & $399 \pm 34(4)$ & 15,6 & 0,8 & $-22,9$ & $-3,2$ & 139 & 485 & \\
\hline NIST - 1633b & 106,12 & $*$ & \multicolumn{4}{|c|}{-} & $*$ & \multicolumn{4}{|c|}{-} & 27 & 83 & \multirow{2}{*}{$8790 \pm 360$} \\
\hline Coal Fly Ash & 277,60 & $8878 \pm 322(4)$ & 7,3 & 1,3 & 1,0 & 0,2 & $8909 \pm 217(3)$ & 11,8 & 1,0 & 1,4 & 0,3 & 53 & 162 & \\
\hline INCT - M3 & 106,12 & $<132$ & \multirow{2}{*}{\multicolumn{4}{|c|}{$\begin{array}{l}- \\
-\end{array}$}} & & \multirow{2}{*}{\multicolumn{4}{|c|}{-}} & 132 & 400 & \multirow{2}{*}{$75,2 \pm 8,2$} \\
\hline Herring Tissue & 277,60 & $<136$ & & & & & & & & & & 136 & 413 & \\
\hline IAEA - SOIL - 7 & 106,12 & $*$ & \multicolumn{4}{|c|}{-} & $*$ & \multicolumn{4}{|c|}{-} & 126 & 383 & \multirow{2}{*}{$2600(2200-3300)$} \\
\hline Trace Elements in Soil & 277,60 & $2256 \pm 110(4)$ & 16,2 & 0,8 & $-13,2$ & $-0,5$ & $2118 \pm 66(4)$ & 8,0 & 0,6 & $-18,5$ & $-0,7$ & 263 & 800 & \\
\hline NIST - 1566b & 106,12 & $292 \pm 23(3)$ & 10,1 & 0,4 & 14,5 & 1,6 & $314 \pm 18(3)$ & 14,5 & 0,8 & 23,1 & 3,2 & 106 & 321 & \multirow{2}{*}{$255 \pm 1,4^{a}$} \\
\hline Oyster Tissue & 277,60 & $* *$ & \multicolumn{4}{|c|}{-} & $* *$ & \multicolumn{4}{|c|}{-} & 132 & 403 & \\
\hline INCT - CTA - VTL - 2 & 106,12 & $160 \pm 13(3)$ & 14,2 & 0,7 & $-1,8$ & $-0,2$ & $154 \pm 42(3)$ & 18,1 & 0,8 & $-5,5$ & $-0,2$ & 26 & 80 & \multirow{2}{*}{$163 \pm 8^{a}$} \\
\hline Virginia Tobacco Leaves & 277,60 & $135 \pm 19(3)$ & 19,0 & 0,9 & $-17,1$ & $-1,3$ & $164 \pm 27(4)$ & 15,5 & 0,7 & 0,5 & 0,03 & 38 & 115 & \\
\hline INCT - OBTL - 5 & 106,12 & $119 \pm 10(3)$ & 19,4 & 0,9 & 5,3 & - & $128 \pm 17(3)$ & 12,0 & 0,6 & 13,5 & - & 29 & 87 & \\
\hline Oriental Basma Tobacco Leaves & 277,60 & $* *$ & \multicolumn{4}{|c|}{-} & $* *$ & & - & & & 50 & 152 & 1130 \\
\hline IPEN - Mexilhão & 106,12 & $<132$ & & & & & & & - & & & 132 & 400 & $112+16^{a}$ \\
\hline & 277,60 & $<159$ & & & & & & & - & & & 159 & 478 & \\
\hline IAEA - RLA 2/014 & 106,12 & $*$ & & & & & $*$ & & - & & & 101 & 308 & \\
\hline Volcanic Ashes & 277,60 & $7303 \pm 136(4)$ & 9,2 & 0,8 & $-14,1$ & $-1,9$ & $8078 \pm 144(4)$ & 5,0 & 0,4 & $-5,0$ & $-0,7$ & 211 & 641 & 200 \\
\hline
\end{tabular}

M - Média aritmética; $\mathrm{u}$ - Incerteza expandida com $\mathrm{k}=2$ e nível de significância de 0,$05 ; \mathrm{n}$ - Número de determinações; DPR - Desvio padrão relativo; ER - Erro relativo; a - Valores informativos; * - Não calculado devido a interferência espectral do ${ }^{153}$ Sm; ** - Não calculado devido às interferências espectrais; $\mathrm{t}_{d}$ - Tempo de decaimento. Fonte: Autora da dissertação. 
Para as contagens realizadas com 9 dias de decaimento, os valores de $\mathrm{Z}$ score dos resultados dos MRCs NIST - 1566b Oyster Tissue e NIST - 1632d Trace Elements in Coal foram maiores que 2 , indicando que estes resultados estão fora da faixa de valores certificados a um nível de significância de 0,05 e que, portanto, são considerados insatisfatórios. Em relação aos valores de HorRat, todos os resultados foram considerados precisos.

Figura 24 - Valores de Z score para as frações mássicas de U nos materiais de referência certificados obtidos por INAA de longa duração com 7 dias de decaimento.

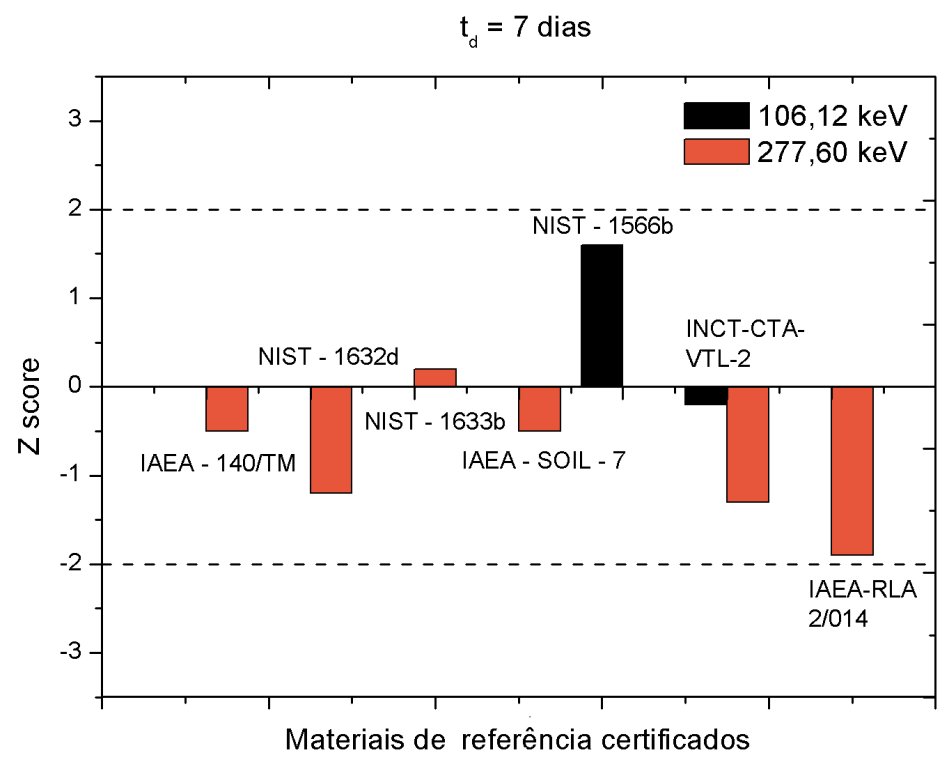

Fonte: Autora da dissertação. 
Figura 25 - Valores de Z score para as frações mássicas de U nos materiais de referência certificados obtidos por INAA de longa duração com 9 dias de decaimento.

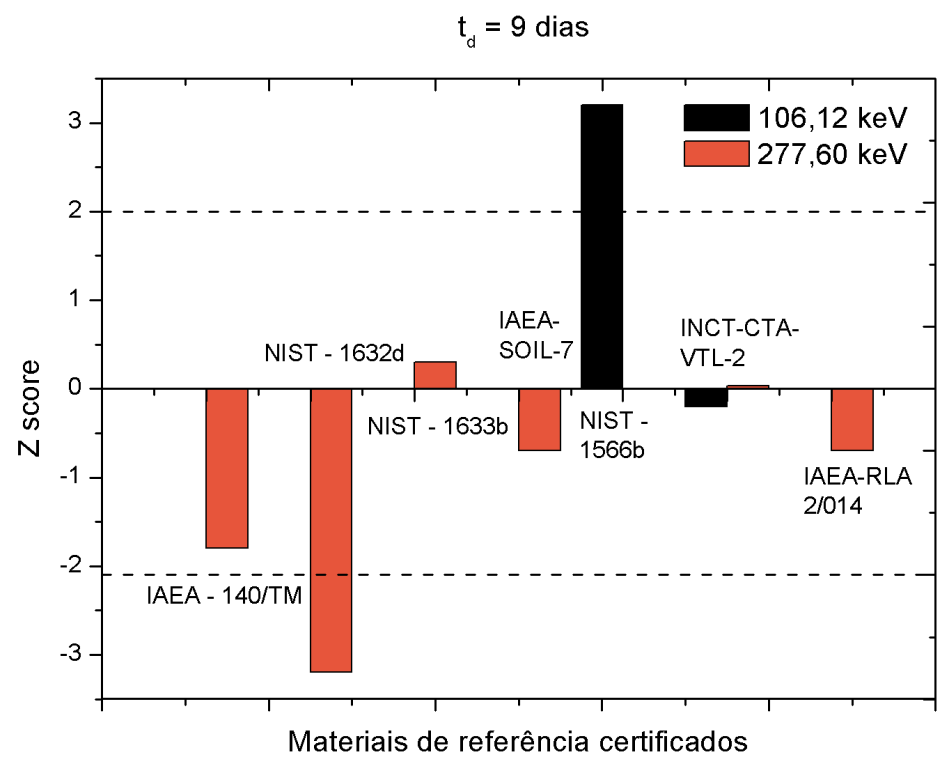

Fonte: Autora da dissertação.

Figura 26 - Valores de HorRat para as frações mássicas de U nos materiais de referência certificados obtidos por INAA de longa duração com 7 dias de decaimento.

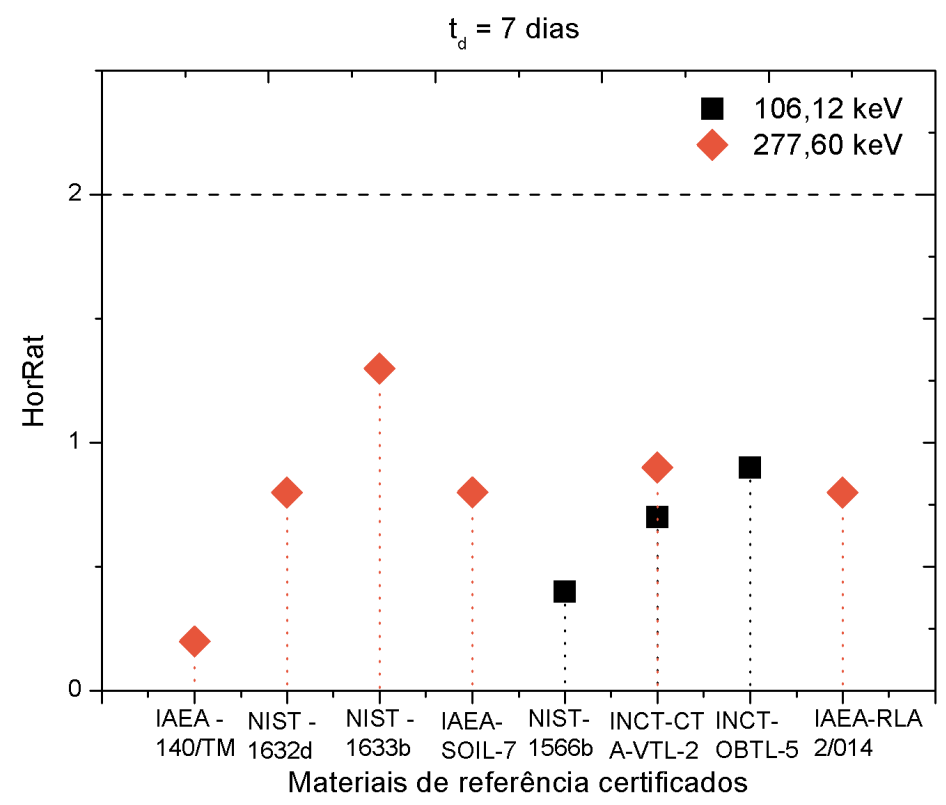

Fonte: Autora da dissertação. 
Figura 27 - Valores de HorRat para as frações mássicas de U nos materiais de referência certificados obtidos por INAA de longa duração com 9 dias de decaimento.

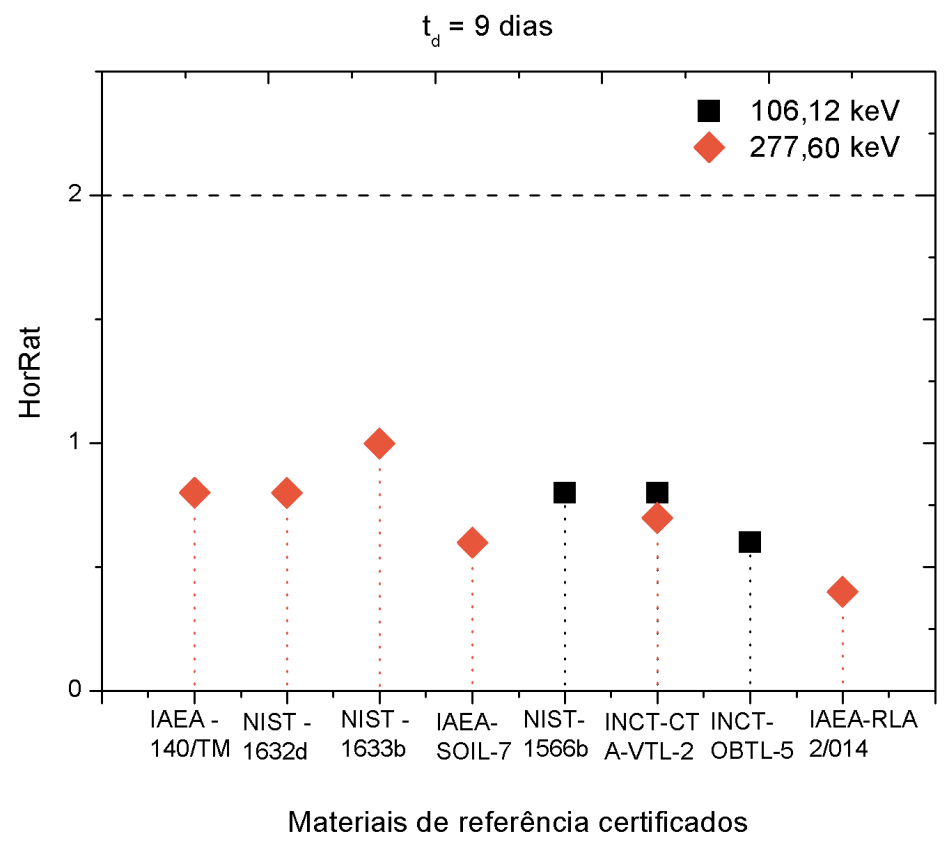

Fonte: Autora da dissertação.

Figura 28 - Espectro do MRC "IAEA - SOIL - 7" obtido por INAA de longa duração.

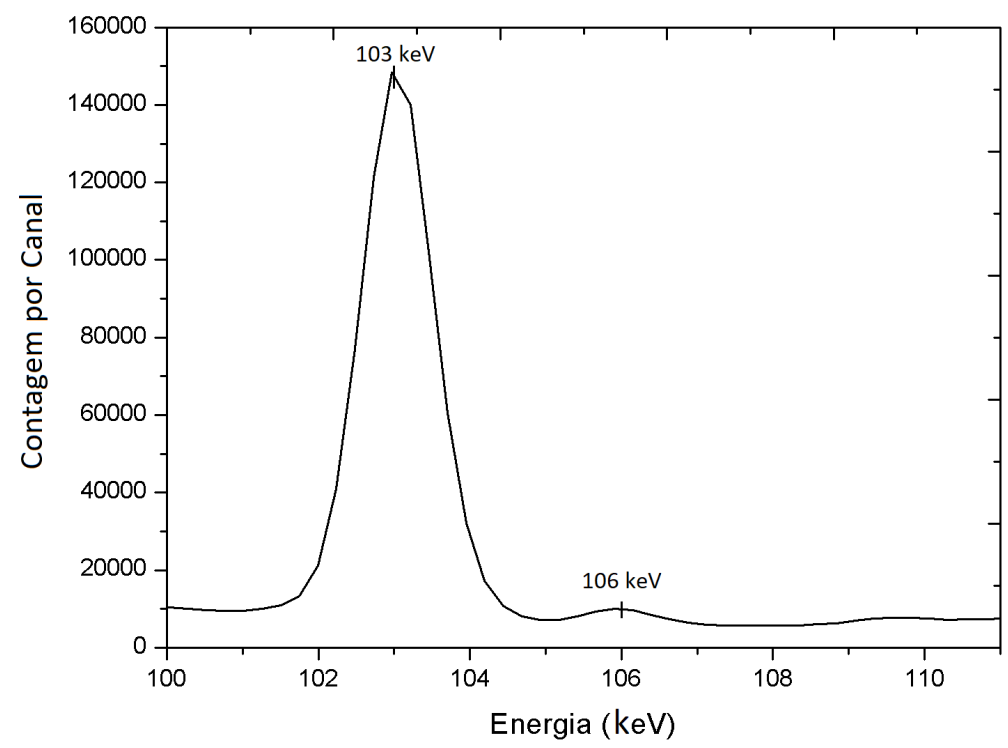

Fonte: Autora da dissertação. 
Figura 29 - Espectro do MRC “INCT - OBTL - 5” obtido por INAA de longa duração.

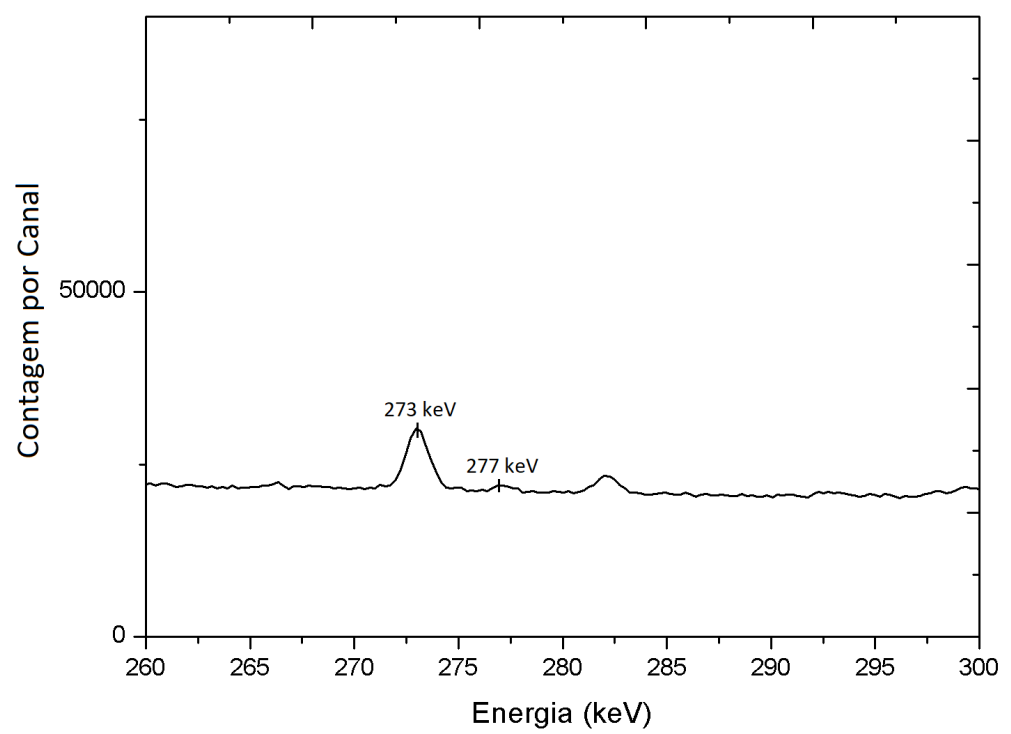

Fonte: Autora da dissertação.

\subsubsection{Análise por ativação com nêutrons epitérmicos de longa duração}

Na Tabela 16 estão apresentadas as médias dos resultados das frações mássicas de U nos MRCs determinadas por ENAA de longa duração. Os resultados foram obtidos usando os picos de $106,12 \mathrm{keV}$ e $277,60 \mathrm{keV}$ do ${ }^{239} \mathrm{~Np}$ para dois tempos de decaimento diferentes. Por meio deste procedimento, todos os materiais de referência tiveram suas frações mássicas de $\mathrm{U}$ quantificadas. Como se pode observar na Tabela 16, os limites de detecção obtidos na ENAA de longa duração são menores para o pico de 106,12 keV do que os de 277,60 keV, e estes limites são, geralmente, inferiores aos calculados para os outros procedimentos estudados neste trabalho. Além disso, na ENAA de longa duração foram obtidos menores valores de incertezas associadas aos resultados das frações mássicas.

Para melhor visualização, os $\mathrm{Z}$ scores e os valores de HorRat calculados foram apresentados nas Figuras de 30 a 33. Nos resultados do MRC NIST - 1566b Oyster Tissue foram obtidos IZ scorel > 2 para o pico de 106,12 keV em ambos os tempos de decaimento utilizados. A dificuldade na determinação de U pelo pico de $106,12 \mathrm{keV}$ do ${ }^{239} \mathrm{~Np}$ se deve à interferência espectral devido à predominância de diversos picos na região de baixa energia. Com a exceção do MRC NIST - 1566b Oyster Tissue, todos os MRCs apresentaram Z scores, em módulo, menores que 2 , indicando que os resultados são exatos. 
Tabela 16 - Frações mássicas de U (ng g $\left.{ }^{-1}\right)$ em materiais de referência certificados obtidas por ENAA de longa duração.

\begin{tabular}{|c|c|c|c|c|c|c|c|c|c|c|c|c|c|c|}
\hline \multirow{2}{*}{ MRC } & \multirow{2}{*}{$\begin{array}{c}\text { Energia dos } \\
\text { raios gama }(\mathrm{keV})\end{array}$} & \multicolumn{5}{|c|}{$t_{d}=2 \mathrm{~d}$} & \multicolumn{5}{|c|}{$t_{d}=4 \mathrm{~d}$} & \multirow{2}{*}{ LD } & \multirow{2}{*}{ LQ } & \multirow{2}{*}{ Valor do certificado } \\
\hline & & $\mathbf{M} \pm \mathbf{u}(\mathbf{n})$ & DPR, \% & HorRat & ER, \% & $Z$ score & $\mathbf{M} \pm \mathbf{u}(\mathbf{n})$ & DPR, \% & HorRat & ER, \% & Z score & & & \\
\hline IAEA - 140/TM & 106,12 & $746 \pm 22(4)$ & 1,6 & 0,3 & 2,1 & 0,2 & $742 \pm 18(4)$ & 5,7 & 1,0 & 1,6 & 0,1 & 30 & 68 & \multirow[t]{2}{*}{$730(647-813)$} \\
\hline Seaweed & 277,60 & $612 \pm 39(5)$ & 16,2 & 0,9 & $-16,1$ & $-1,2$ & $641 \pm 33(3)$ & 1,2 & 0,1 & $-12,2$ & $-0,9$ & 91 & 206 & \\
\hline NIST - 1575 & 106,12 & $18 \pm 2(4)$ & 6,6 & 0,04 & $-10,6$ & $-0,5$ & $18 \pm 1(3)$ & 9,0 & 0,2 & $-9,9$ & $-0,5$ & 3 & 8 & \multirow{2}{*}{$20 \pm 4$} \\
\hline Pine Needles & 277,60 & $17 \pm 4(3)$ & 20,2 & 0,3 & $-14,0$ & $-0,5$ & $17 \pm 3(4)$ & 23,2 & 0,1 & $-12,9$ & $-0,5$ & 6 & 17 & \\
\hline NIST - 1632d & 106,12 & $535 \pm 12(6)$ & 16,7 & 0,2 & 3,6 & 1,1 & $550 \pm 13(5)$ & 27,7 & 1,6 & 6,4 & 1,9 & 8 & 26 & \multirow{2}{*}{$517 \pm 12$} \\
\hline Trace Elements in Coal & 277,60 & $507 \pm 15(5)$ & 4,4 & 1,6 & $-2,0$ & $-0,7$ & $503 \pm 16(6)$ & 20,2 & 0,2 & $-2,7$ & $-0,7$ & 15 & 46 & \\
\hline NIST - 1633b & 106,12 & $9277 \pm 145(3)$ & 6,1 & 1,8 & 5,5 & 1,3 & $8753 \pm 132(2)$ & 7,9 & 0,7 & 0,4 & $-0,1$ & 28 & 83 & \multirow{2}{*}{$8790 \pm 360$} \\
\hline Coal Fly Ash & 277,60 & $8417 \pm 158(6)$ & 12,0 & 1,0 & $-4,2$ & $-0,9$ & $8951 \pm 162(6)$ & 16,1 & 1,0 & 1,8 & 0,4 & 51 & 158 & \\
\hline INCT - M3 & 106,12 & $57 \pm 5(5)$ & 19,9 & 0,8 & $-23,7$ & $-1,8$ & $70 \pm 11(6)$ & 24,4 & 0,9 & $-5,9$ & $-0,3$ & 22 & 67 & \multirow{2}{*}{$75,2 \pm 8,2$} \\
\hline Herring Tissue & 277,60 & $* *$ & \multicolumn{4}{|c|}{-} & $* *$ & \multicolumn{4}{|c|}{-} & 69 & 212 & \\
\hline IAEA - SOIL - 7 & 106,12 & $2091 \pm 22(4)$ & 31,1 & 2,2 & $-19,6$ & $-0,7$ & $2508 \pm 50(4)$ & 18,8 & 1,3 & $-3,5$ & $-0,1$ & 8 & 26 & \multirow{2}{*}{$2600(2200-3300)$} \\
\hline Trace Elements in Soil & 277,60 & $2502 \pm 51(4)$ & 3,3 & 1,3 & $-3,8$ & $-0,1$ & $2494 \pm 73(4)$ & 3,2 & 0,2 & $-4,1$ & $-0,1$ & 16 & 50 & \\
\hline NIST - 1566b & 106,12 & $284 \pm 10(2)$ & 5,4 & 0,2 & 11,4 & 2,9 & $291 \pm 10(3)$ & 2,8 & 0,3 & 14,0 & 3,6 & 15 & 44 & \multirow{2}{*}{$255 \pm 1,4^{a}$} \\
\hline Oyster Tissue & 277,60 & $230 \pm 17(2)$ & 2,0 & 0,1 & $-9,7$ & $-1,5$ & $276 \pm 17(3)$ & 15,7 & 0,1 & 8,3 & 1,2 & 31 & 96 & \\
\hline INCT - CTA - VTL - 2 & 106,12 & $177 \pm 8(3)$ & 6,0 & 0,7 & 8,4 & 1,2 & $168 \pm 7(3)$ & 8,8 & 0,3 & 3,1 & 0,5 & 15 & 45 & \multirow{2}{*}{$163 \pm 8^{a}$} \\
\hline Virginia Tobacco Leaves & 277,60 & $168 \pm 15(3)$ & 4,6 & 0,4 & 3,0 & 0,3 & $170 \pm 12(3)$ & 8,9 & 0,2 & 4,6 & 0,5 & 24 & 72 & \\
\hline INCT - OBTL - 5 & 106,12 & $118 \pm 9(3)$ & 3,1 & 0,4 & 4,5 & - & $121 \pm 10(4)$ & 11,7 & 0,5 & 7,4 & - & 15 & 46 & \multirow{2}{*}{$113^{a}$} \\
\hline Oriental Basma Tobacco Leaves & 277,60 & $121 \pm 20(3)$ & 2,6 & 0,1 & 6,9 & - & $108 \pm 22(3)$ & 19,9 & 0,9 & $-4,5$ & - & 33 & 100 & \\
\hline \multirow{2}{*}{ IPEN - Mexilhão } & 106,12 & $100 \pm 9(3)$ & 32,4 & 0,9 & $-10,9$ & $-0,7$ & $94 \pm 10(3)$ & 12,3 & 1,4 & $-15,9$ & $-0,9$ & 16 & 48 & \multirow{2}{*}{$112 \pm 16^{a}$} \\
\hline & 277,60 & $91 \pm 21(3)$ & 50,0 & 2,2 & $-19,0$ & $-0,8$ & $63 \pm 22(3)$ & 3,2 & 0,1 & $-44,1$ & $-1,8$ & 38 & 115 & \\
\hline IAEA - RLA 2/014 & 106,12 & $8261 \pm 132(3)$ & 5,9 & 0,3 & $-2,8$ & $-0,4$ & $8065 \pm 133(2)$ & 3,7 & 0,3 & $-5,1$ & $-0,7$ & 18 & 55 & \multirow{2}{*}{$8500 \pm 600$} \\
\hline Volcanic Ashes & 277,60 & $8226 \pm 138(4)$ & 3,7 & 0,3 & $-3,2$ & $-0,4$ & $8356 \pm 148(4)$ & 3,9 & 0,3 & $-1,7$ & $-0,2$ & 28 & 87 & \\
\hline
\end{tabular}

M - Média aritmética; $\mathrm{u}$ - Incerteza expandida com k = 2 e nível de significância de 0,05; $\mathrm{n}$ - Número de determinações; DPR - Desvio padrão relativo;

ER - Erro relativo; a - Valores informativos; ** - Não calculado devido às interferências espectrais; $\mathrm{t}_{d}$ - Tempo de decaimento. Fonte: Autora da dissertação. 
No MRC IPEN - Mexilhão foi obtido o maior valor de ER, igual a 44\%, dentre os resultados apresentados. Em relação aos outros materiais, os resultados obtidos para o pico de 277,60 keV, com 4 dias de decaimento apresentaram ERs que variaram de 0,4\% a 16,1\%. Quanto aos valores de HorRat obtidos para 2 dias de decaimento, os MRCs IAEA - SOIL - 7 e IPEN - Mexilhão apresentaram, para os resultados calculados usando o pico de 106,12 keV, valores de HorRat > 2, indicando a não reprodutibilidade dos dados obtidos. Como pode ser visto na Figura 34, a irradiação epitérmica reduziu o problema de interferência espectral do pico de $103,18 \mathrm{keV}$ do ${ }^{153} \mathrm{Sm}$ no pico de $106,12 \mathrm{keV}$ do ${ }^{239} \mathrm{~Np}$, em comparação com o espectro resultante da irradiação térmica. Esse espectro de raios gama foi obtido pela ENAA de longa duração numa alíquota do MRC IAEA - SOIL - 7 e mostra que, apesar da alta atividade do pico de $103,18 \mathrm{keV}$ do ${ }^{153} \mathrm{Sm}$ em relação ao pico de $106,12 \mathrm{keV}$ do ${ }^{239} \mathrm{~Np}$, este se encontra melhor definido do que o observado na Figura 28. Em consequência disso, a fração mássica de U só pôde ser determinada pelo pico de $106,12 \mathrm{keV}$ do ${ }^{239} \mathrm{~Np}$ por ENAA de longa duração.

No MRC INCT - M3 Herring Tissue, a fração mássica de U não foi determinada para o pico de $277,60 \mathrm{keV}$ do ${ }^{239} \mathrm{~Np}$ devido ao problema das interferências espectrais e baixas taxas de contagens, além deste pico se encontrar em uma região complexa do espectro. A Figura 35 apresenta o espectro obtido por ENAA de longa duração na irradiação do MRC INCT - M3 Herring Tissue. Nesta região do espectro de raios gama, nota-se o background consideravelmente alto, além do pico de $277,60 \mathrm{keV}$ do ${ }^{239} \mathrm{~Np}$ aparecer acompanhado do pico de $273 \mathrm{keV}$, este com maior número de contagens. Além disso, elementos como o ${ }^{203} \mathrm{Hg}$ e o ${ }^{75} \mathrm{Se}$ apresentam emissões nessa região do espectro. Estes fatos dificultaram a detecção do pico de 277,60 keV pelo sistema detector, impedindo a quantificação do U.

Figura 30 - Valores de Z score para as frações mássicas de U nos materiais de referência certificados obtidos por ENAA de longa duração com 2 dias de decaimento.

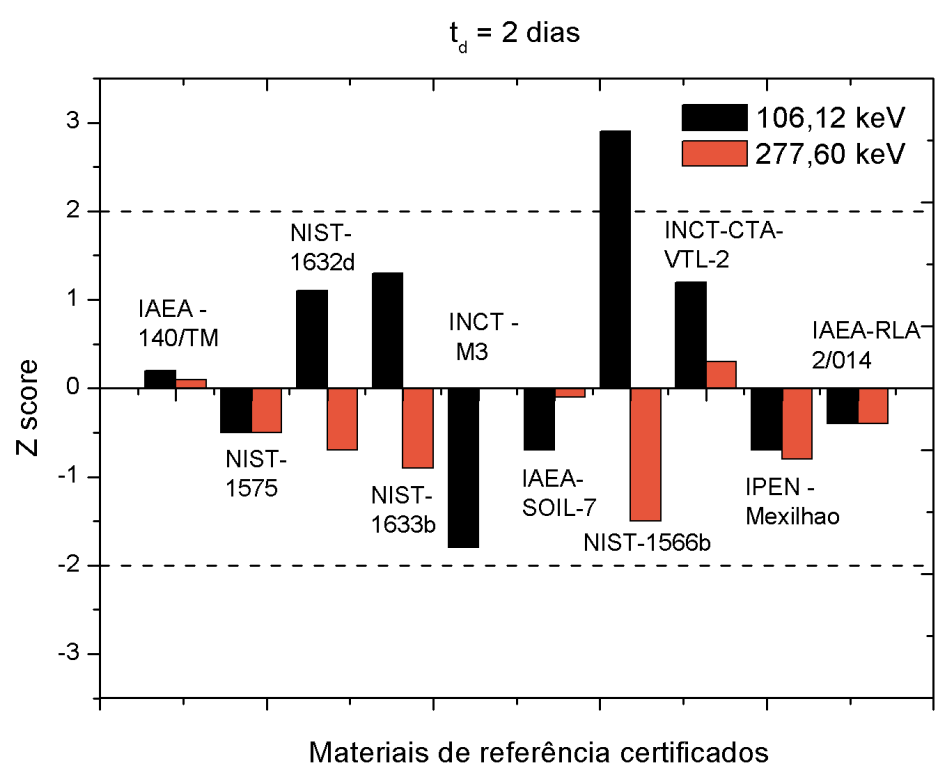

Fonte: Autora da dissertação. 
Figura 31 - Valores de Z score para as frações mássicas de U nos materiais de referência certificados obtidos por ENAA de longa duração com 4 dias de decaimento.

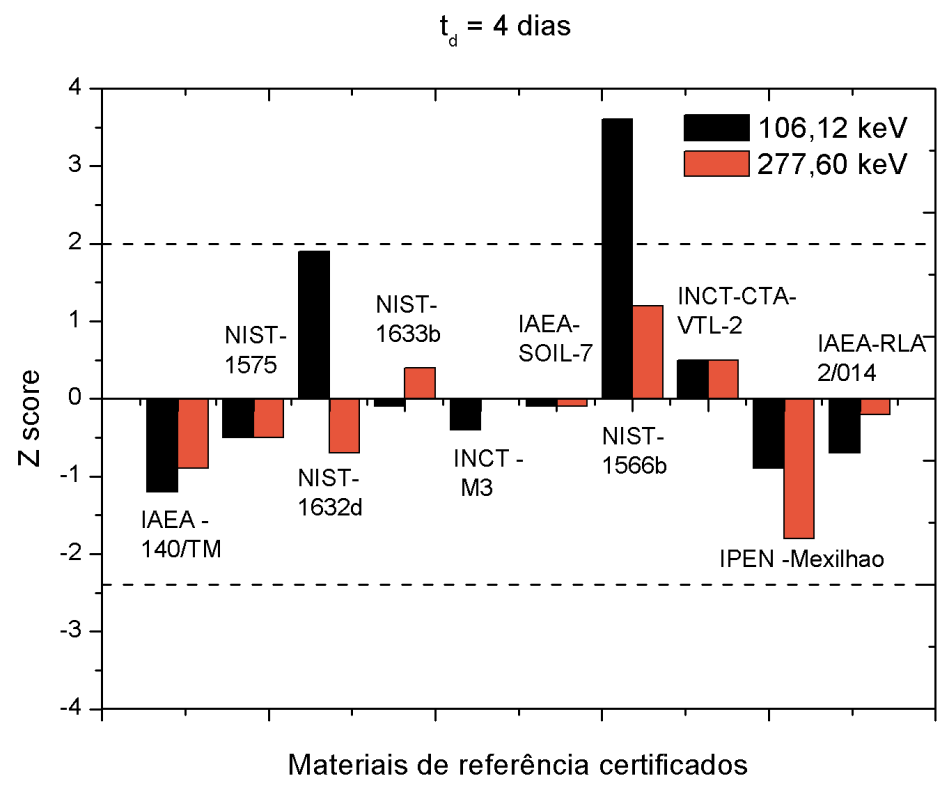

Fonte: Autora da dissertação.

Figura 32 - Valores de HorRat para as frações mássicas de U nos materiais de referência certificados obtidos por ENAA de longa duração com 2 dias de decaimento.

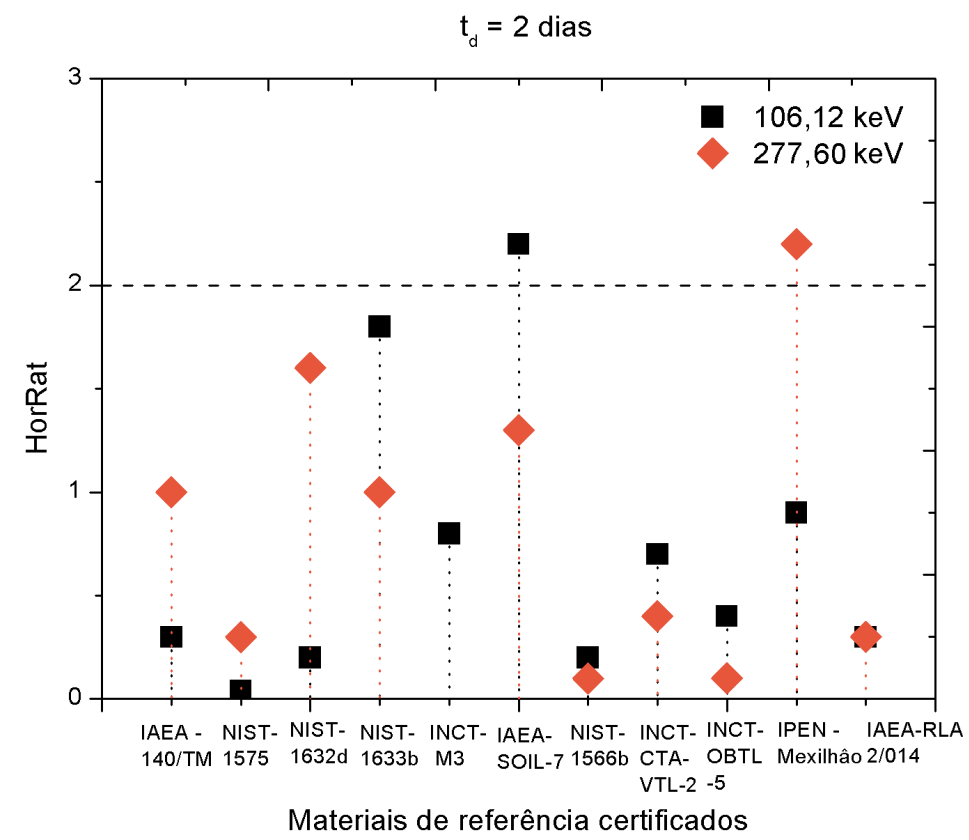

Fonte: Autora da dissertação. 
Figura 33 - Valores de HorRat para as frações mássicas de U nos materiais de referência certificados obtidos por ENAA de longa duração com 4 dias de decaimento.

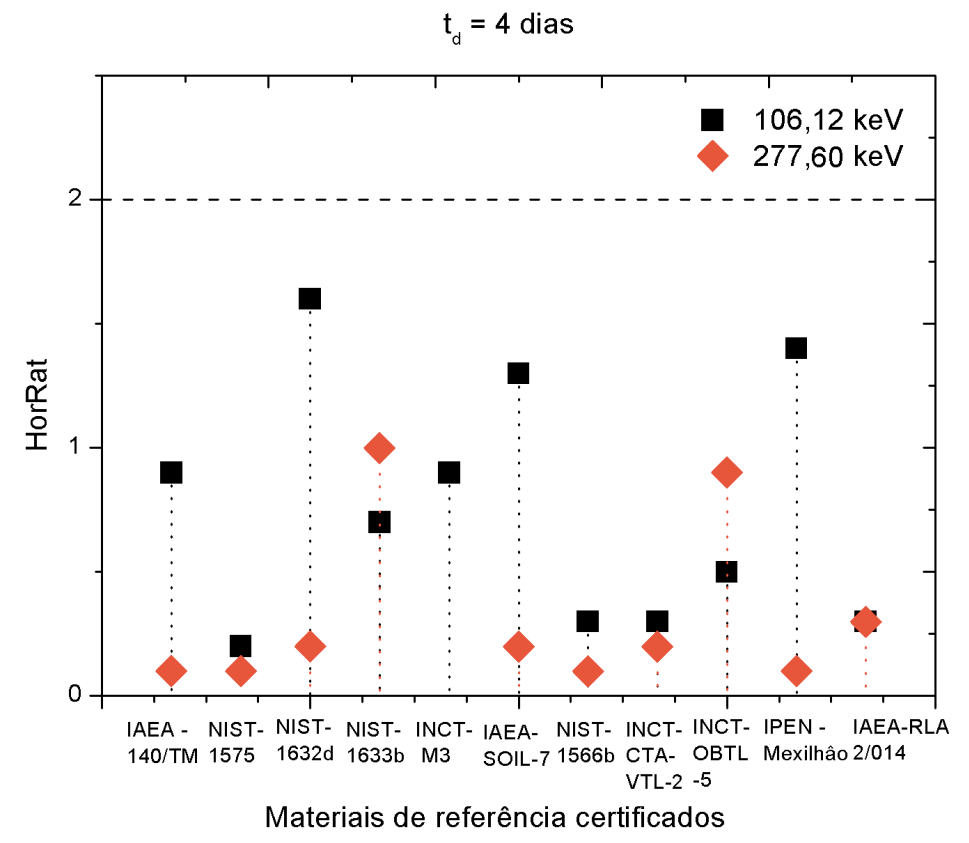

Fonte: Autora da dissertação.

Figura 34 - Espectro do MRC “IAEA - SOIL - 7” obtido por ENAA de longa duração.

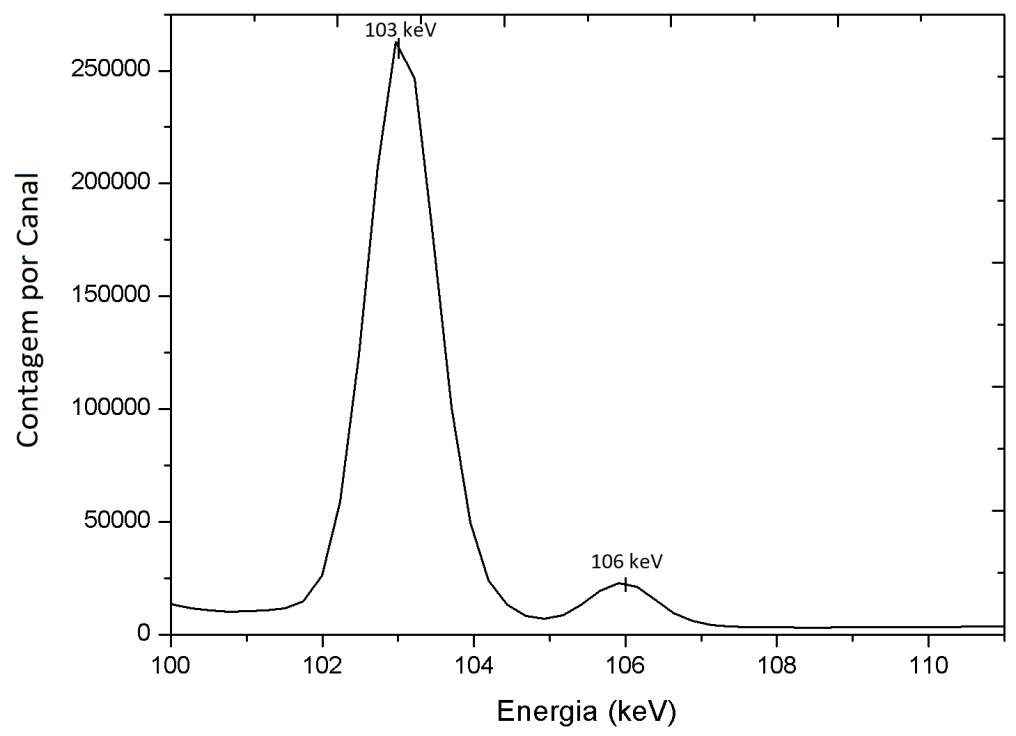

Fonte: Autora da dissertação. 
Figura 35 - Espectro do MRC “INCT - M3” obtido por ENAA de longa duração.

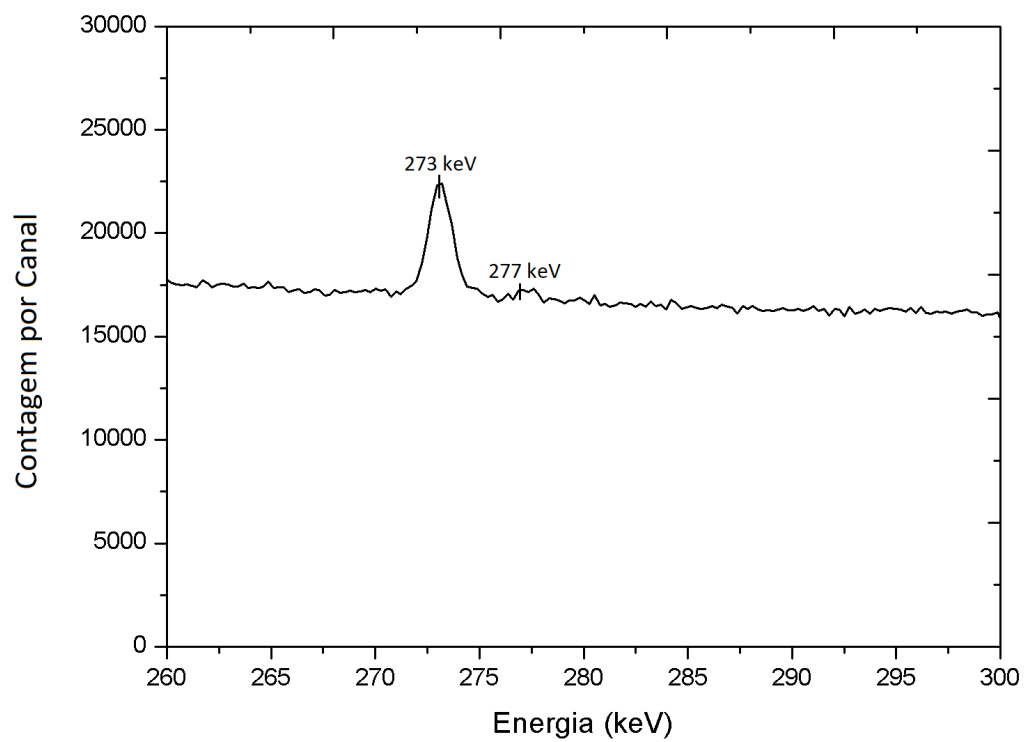

Fonte: Autora da dissertação.

\subsection{Resultados da determinação de urânio em amostras de cascas de árvores}

Neste trabalho, foram determinadas as frações mássicas de U em oito amostras de cascas de árvores por meio de INAA e ENAA de curta e longa duração. São apresentadas as médias das frações mássicas de U (M) com as incertezas expandidas (u), os valores de desvio padrão relativo (DPR), HorRat e os limites de detecção (LD) e de quantificação (LQ). Foi realizada a verificação da existência de valores extremos (outliers) nos conjuntos de dados, e para isso foi aplicado o teste de Grubbs a nível de 0,05 de significância. Alguns outliers foram identificados e excluídos do conjunto de dados. Os resultados individuais obtidos nas determinações de U nas cascas de árvores estão apresentados nas tabelas do Apêndice B desta dissertação.

\subsubsection{Irradiações de curta duração de amostras de cascas de árvores}

\subsubsection{Análise por ativação com nêutrons térmicos e epitérmicos de curta duração}

Os resultados das determinações de U em amostras de cascas de árvores pelos procedimentos de curta duração foram obtidos utilizando o pico de $74,66 \mathrm{keV}$ do ${ }^{239} \mathrm{U}$. Como pode ser visto na Tabela 17, as frações mássicas de U determinadas nas cascas de árvores por ENAA de curta duração, variaram de $83 \pm 43 \mathrm{ng} \mathrm{g}^{-1}$ a $588 \pm 61 \mathrm{ng} \mathrm{g}^{-1}$. Não foi quantificado U nas cascas de árvores aplicando o procedimento de INAA de curta duração, pois as frações mássicas foram inferiores aos seus limites de detecção. A precisão dos dados obtidos foi avaliada pelos valores de HorRat, que estão apresentados na Tabela 17 e na Figura 36. Os 
valores de HorRat foram menores do que 2 indicando que os resultados obtidos são precisos, de acordo com o critério de HorRat.

Tabela 17 - Frações mássicas de U $\left(\mathrm{ng} \mathrm{g}^{-1}\right.$ ) determinadas em cascas de árvores por INAA e ENAA de curta duração.

\begin{tabular}{|c|c|c|c|c|c|c|}
\hline $\begin{array}{c}\text { Cascas de } \\
\text { árvores }\end{array}$ & Técnica & $\mathbf{M} \pm \mathbf{u}(\mathbf{n})$ & DPR, \% & HorRat & LD & LQ \\
\hline \multirow{2}{*}{1} & ENAA & $99 \pm 33(2)$ & 0,1 & 0,004 & 31 & 94 \\
\hline & INAA & $<284$ & \multicolumn{2}{|c|}{-} & 284 & 863 \\
\hline \multirow{2}{*}{2} & ENAA & $83 \pm 43^{*}(4)$ & 10,0 & 0,4 & 37 & 113 \\
\hline & INAA & $<325$ & \multicolumn{2}{|c|}{-} & 325 & 989 \\
\hline \multirow{2}{*}{3} & ENAA & $133 \pm 35^{*}(3)$ & 1,8 & 0,1 & 93 & 283 \\
\hline & INAA & $<249$ & \multicolumn{2}{|c|}{-} & 249 & 758 \\
\hline \multirow{2}{*}{4} & ENAA & $128 \pm 39$ & 15,2 & 0,7 & 37 & 133 \\
\hline & INAA & $<378$ & \multicolumn{2}{|c|}{-} & 378 & 1147 \\
\hline \multirow{2}{*}{5} & ENAA & $184 \pm 47(4)$ & 10,8 & 0,5 & 44 & 135 \\
\hline & INAA & $<281$ & \multicolumn{2}{|c|}{-} & 281 & 857 \\
\hline \multirow{2}{*}{6} & ENAA & $588 \pm 61(4)$ & 5,6 & 0,3 & 80 & 243 \\
\hline & INAA & $<314$ & \multicolumn{2}{|c|}{-} & 314 & 954 \\
\hline \multirow{2}{*}{7} & ENAA & $206 \pm 50(4)$ & 2,1 & 0,1 & 52 & 158 \\
\hline & INAA & $<205$ & \multicolumn{2}{|c|}{-} & 205 & 624 \\
\hline \multirow{2}{*}{8} & ENAA & $583 \pm 7(4)$ & 11,7 & 0,7 & 122 & 372 \\
\hline & INAA & $<235$ & \multicolumn{2}{|c|}{-} & 235 & 717 \\
\hline
\end{tabular}

M - Média aritmética; $u$ - Incerteza expandida com $k=2$ e nível de significância de 0,05 ; n - Número de determinações; DPR - Desvio padrão relativo; LD - Limite de detecção; LQ - Limite de quantificação; * - Resultados obtidos na segunda contagem. Fonte: Autora da dissertação. 
Figura 36 - Valores de HorRat para as frações mássicas de U nas cascas de árvores obtidas por ENAA de curta duração.

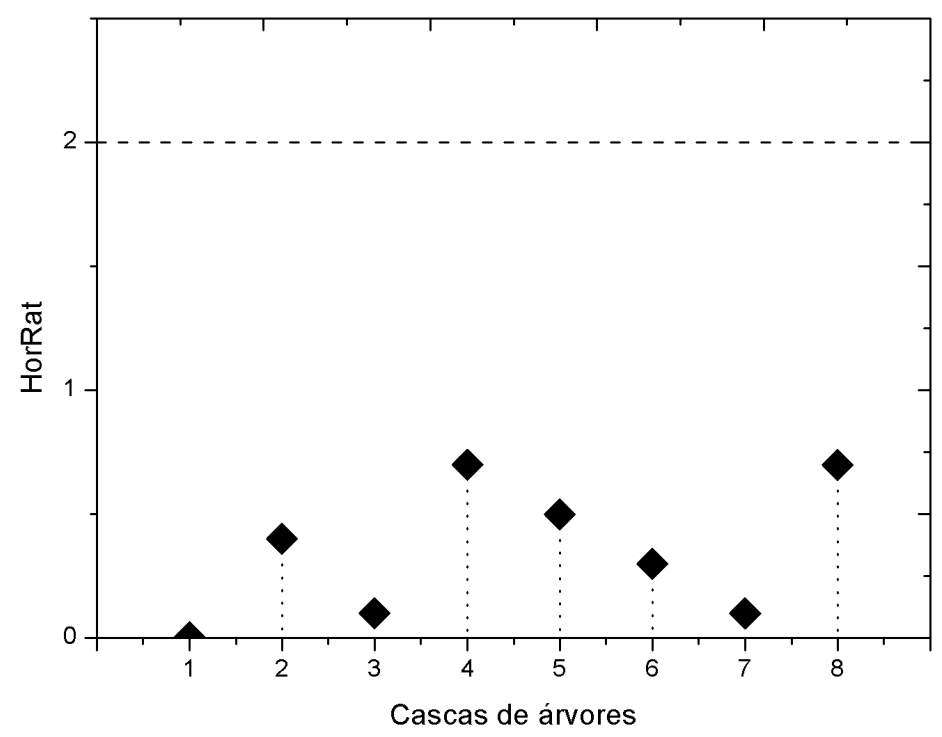

Fonte: Autora da dissertação.

\subsubsection{Irradiações de longa duração de amostras de cascas de árvores}

\subsubsection{Análise por ativação com nêutrons térmicos de longa duração}

Na Tabela 18 estão apresentadas as médias das frações mássicas resultantes da determinação de U em cascas de árvores por INAA de longa duração. Esses resultados foram obtidos usando os picos de $106,12 \mathrm{keV}$ e $277,60 \mathrm{keV}$ do ${ }^{239} \mathrm{~Np}$ para o tempo de decaimento de 7 dias. Todas as amostras de casca de árvore apresentaram problemas na quantificação de U pelo pico de 106,12 keV devido à interferência espectral do ${ }^{135} \mathrm{Sm}$.

As frações mássicas de $\mathrm{U}$ determinadas nas cascas pelo pico de 277,60 keV variaram de $81 \pm 10 \mathrm{ng} \mathrm{g}^{-1}$ a $502 \pm 4 \mathrm{ng} \mathrm{g}^{-1}$ e as incertezas expandidas associadas a estes resultados foram inferiores às obtidas por ENAA de curta duração. Com relação à reprodutibilidade, os valores de HorRat, que foram menores ou iguais a 2, indicaram a precisão dos dados obtidos, os quais estão apresentados na Tabela 18 e na Figura 37. 
Tabela 18 - Frações mássicas de $\mathrm{U}\left(\mathrm{ng} \mathrm{g}^{-1}\right)$ determinadas em cascas de árvores por INAA de longa duração com tempo de decaimento de 7 dias.

\begin{tabular}{|c|c|c|c|c|c|c|}
\hline $\begin{array}{c}\text { Cascas de } \\
\text { árvores }\end{array}$ & $\begin{array}{c}\text { Energia dos } \\
\text { raios gama } \\
(\mathrm{keV})\end{array}$ & $\mathbf{M} \pm \mathbf{u}(\mathbf{n})$ & DPR, \% & HorRat & LD & LQ \\
\hline \multirow{2}{*}{1} & 106,12 & $*$ & \multicolumn{2}{|c|}{-} & 14 & 42 \\
\hline & 277,60 & $167 \pm 8(3)$ & 43,6 & 2,0 & 25 & 75 \\
\hline \multirow{2}{*}{2} & 106,12 & $*$ & \multicolumn{2}{|c|}{-} & 8 & 24 \\
\hline & 277,60 & $81 \pm 10(3)$ & 21,9 & 0,9 & 13 & 40 \\
\hline \multirow{2}{*}{3} & 106,12 & $*$ & \multicolumn{2}{|c|}{-} & 19 & 58 \\
\hline & 277,60 & $110 \pm 17(3)$ & 6,8 & 0,3 & 35 & 106 \\
\hline \multirow{2}{*}{4} & 106,12 & $*$ & \multicolumn{2}{|c|}{-} & 11 & 35 \\
\hline & 277,60 & $122 \pm 8(3)$ & 24,5 & 1,1 & 18 & 54 \\
\hline \multirow{2}{*}{5} & 106,12 & $*$ & \multicolumn{2}{|c|}{-} & 16 & 50 \\
\hline & 277,60 & $149 \pm 13(3)$ & 43,7 & 2,0 & 26 & 77 \\
\hline \multirow{2}{*}{6} & 106,12 & $*$ & \multicolumn{2}{|c|}{-} & 14 & 42 \\
\hline & 277,60 & $502 \pm 4(3)$ & 7,3 & 0,4 & 25 & 75 \\
\hline \multirow{2}{*}{7} & 106,12 & $*$ & \multicolumn{2}{|c|}{-} & 22 & 68 \\
\hline & 277,60 & $156 \pm 17(3)$ & 26,5 & 1,2 & 35 & 109 \\
\hline \multirow{2}{*}{8} & 106,12 & $*$ & \multicolumn{2}{|c|}{-} & 18 & 56 \\
\hline & 277,60 & $454 \pm 6(3)$ & 6,5 & 0,4 & 33 & 102 \\
\hline
\end{tabular}

M - Média aritmética; $u$ - Incerteza expandida com $k=2$ e nível de significância de 0,$05 ; n$ - Número de determinações; DPR - Desvio padrão relativo; LD - Limite de detecção; LQ Limite de quantificação; * - Não calculado devido à interferência espectral do ${ }^{153} \mathrm{Sm}$. Fonte: Autora da dissertação. 
Figura 37 - Valores de HorRat para as frações mássicas de U nas cascas de árvores obtidas por INAA de longa duração.

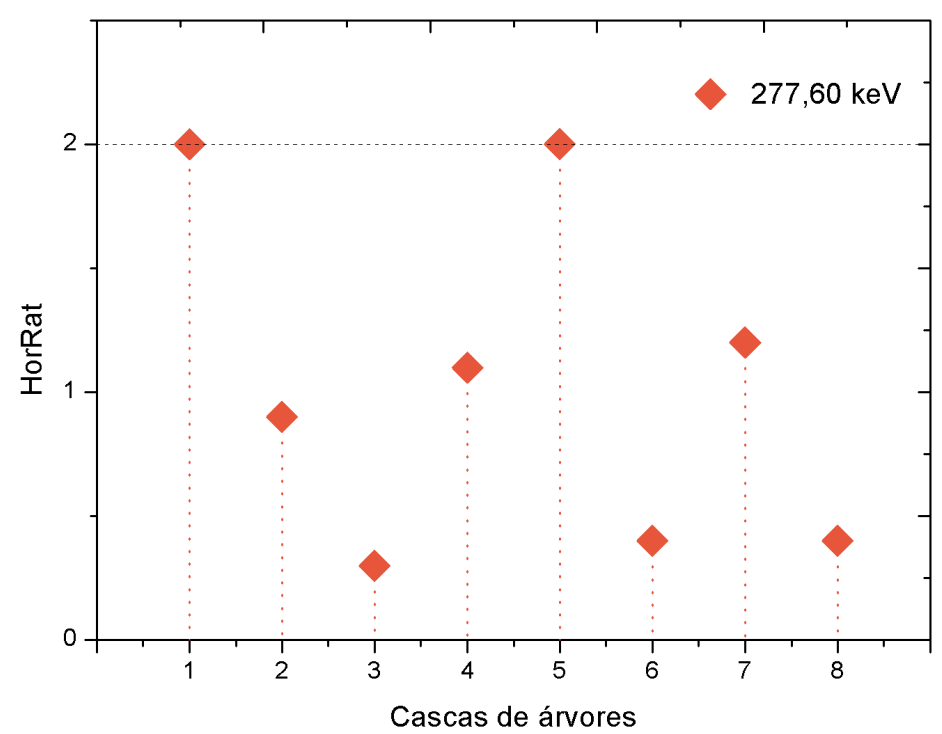

Fonte: Autora da dissertação.

\subsubsection{Análise por ativação com nêutrons epitérmicos de longa duração}

Na Tabela 19 são apresentados os resultados das determinações de U em cascas de árvores por ENAA de longa duração. Esses resultados foram obtidos usando os picos de $106,12 \mathrm{keV}$ e $277,60 \mathrm{keV}$ do ${ }^{239} \mathrm{~Np}$ para dois tempos de decaimento. As frações mássicas de $\mathrm{U}$ variaram de $90 \pm 4 \mathrm{ng} \mathrm{g}^{-1}$ a $699 \pm 32 \mathrm{ng} \mathrm{g}^{-1}$ para resultados obtidos com 2 dias de decaimento e de $87 \pm 6 \mathrm{ng} \mathrm{g}^{-1}$ a $762 \pm 13 \mathrm{ng} \mathrm{g}^{-1}$ para 4 dias de decaimento. Portanto, os intervalos de frações mássicas de U resultantes das medições com 2 e 4 dias de decaimento foram similares. As incertezas expandidas obtidas por ENAA de longa duração foram, em geral, inferiores às obtidas por ENAA e INAA de curta e longa duração.

Os limites de detecção e de quantificação seguiram a mesma tendência, com valores menores ou iguais aos obtidos por INAA de longa duração. Esse fato ocorreu porque a irradiação epitérmica permitiu obter um espectro de raios gama com baixa radiação de fundo (Background) devido a redução das atividades de alguns interferentes. Além disso, os limites de detecção obtidos para o pico de 106,12 keV foram menores do que os obtidos para $277,60 \mathrm{keV}$. A precisão dos resultados foi avaliada pelos valores de HorRat, que estão apresentados nas Figuras 38 e 39 para tempos de decaimento de 2 e 4 dias, respectivamente. De acordo com o critério de HorRat, o conjunto de dados obtidos é reprodutível, pois os valores de HorRat foram menores que 2. 
Tabela 19 - Frações mássicas de U (ng g $\left.{ }^{-1}\right)$ determinadas em cascas de árvores por ENAA de longa duração.

\begin{tabular}{|c|c|c|c|c|c|c|c|c|c|}
\hline \multirow{2}{*}{$\begin{array}{c}\text { Cascas de } \\
\text { árvores }\end{array}$} & \multirow{2}{*}{ Energia dos raios gama $(\mathrm{keV})$} & \multicolumn{3}{|c|}{$t_{d}=\mathbf{2} \mathbf{d}$} & \multicolumn{3}{|c|}{$t_{d}=4 \mathrm{~d}$} & \multirow{2}{*}{ LD } & \multirow{2}{*}{ LQ } \\
\hline & & $\mathbf{M} \pm \mathbf{u}(\mathbf{n})$ & DPR, \% & HorRat & $\mathbf{M} \pm \mathbf{u}(\mathbf{n})$ & DPR, \% & HorRat & & \\
\hline \multirow{2}{*}{1} & 106,12 & $94 \pm 3(4)$ & 8,5 & 0,3 & $94 \pm 3(4)$ & 10,5 & 0,5 & 6 & 18 \\
\hline & 277,60 & $98 \pm 6(4)$ & 16,1 & 0,7 & $87 \pm 6(4)$ & 4,5 & 0,2 & 14 & 42 \\
\hline \multirow{2}{*}{2} & 106,12 & $93 \pm 2(4)$ & 5,8 & 0,2 & $93 \pm 3(4)$ & 7,8 & 0,3 & 6 & 19 \\
\hline & 277,60 & $90 \pm 4(4)$ & 6,8 & 0,3 & $95 \pm 6(4)$ & 12,2 & 0,5 & 14 & 41 \\
\hline \multirow{2}{*}{3} & 106,12 & $146 \pm 3(4)$ & 15,0 & 0,7 & $147 \pm 4(4)$ & 14,9 & 0,7 & 7 & 21 \\
\hline & 277,60 & $145 \pm 6(4)$ & 14,5 & 0,7 & $140 \pm 6(4)$ & 16,0 & 0,7 & 16 & 50 \\
\hline \multirow{2}{*}{4} & 106,12 & $143 \pm 3(4)$ & 15,5 & 0,7 & $142 \pm 5(4)$ & 12,5 & 0,6 & 5 & 17 \\
\hline & 277,60 & $136 \pm 5(4)$ & 10,8 & 0,5 & $134 \pm 5(4)$ & 16,5 & 0,8 & 12 & 36 \\
\hline \multirow{2}{*}{5} & 106,12 & $207 \pm 4(4)$ & 28,5 & 1,4 & $137 \pm 5(4)$ & 18,0 & 0,8 & 6 & 18 \\
\hline & 277,60 & $191 \pm 6(4)$ & 28,7 & 1,4 & $191 \pm 6(4)$ & 28,6 & 1,4 & 12 & 37 \\
\hline \multirow{2}{*}{6} & 106,12 & $695 \pm 11(4)$ & 10,2 & 0,6 & $694 \pm 14(4)$ & 14,2 & 0,8 & 12 & 36 \\
\hline & 277,60 & $660 \pm 14(4)$ & 6,2 & 0,4 & $675 \pm 14(4)$ & 8,1 & 0,5 & 25 & 77 \\
\hline \multirow{2}{*}{7} & 106,12 & $204 \pm 8(4)$ & 6,4 & 0,3 & $205 \pm 4(4)$ & 5,6 & 0,3 & 7 & 20 \\
\hline & 277,60 & $201 \pm 4(4)$ & 7,2 & 0,3 & $198 \pm 6(4)$ & 2,2 & 0,1 & 15 & 45 \\
\hline \multirow{2}{*}{8} & 106,12 & $600 \pm 17(4)$ & 15,8 & 0,9 & $711 \pm 13(4)$ & 13,6 & 0,8 & 5 & 17 \\
\hline & 277,60 & $609 \pm 32(4)$ & 10,0 & 0,6 & $572 \pm 14(4)$ & 13,2 & 0,7 & 11 & 36 \\
\hline
\end{tabular}

M - Média aritmética; u - Incerteza expandida com k = 2 e nível de significância de 0,05; $\mathrm{n}$ - Número de determinações; DPR - Desvio padrão relativo; LD - Limite de detecção; LQ - Limite de quantificação; $t_{d}$ - Tempo de decaimento. Fonte: Autora da dissertação. 
Figura 38 - Valores de HorRat para as frações mássicas de U nas cascas de árvores obtidas por ENAA de longa duração com 2 dias de decaimento.

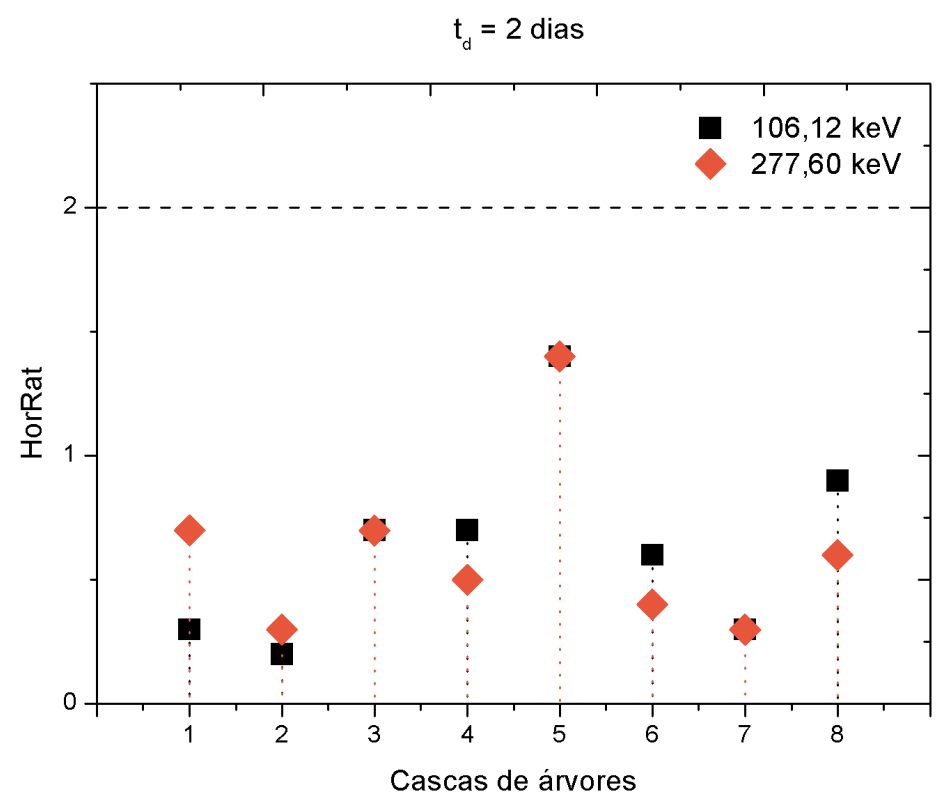

Fonte: Autora da dissertação.

Figura 39 - Valores de HorRat para as frações mássicas de U nas cascas de árvores obtidas por ENAA de longa duração com 4 dias de decaimento.

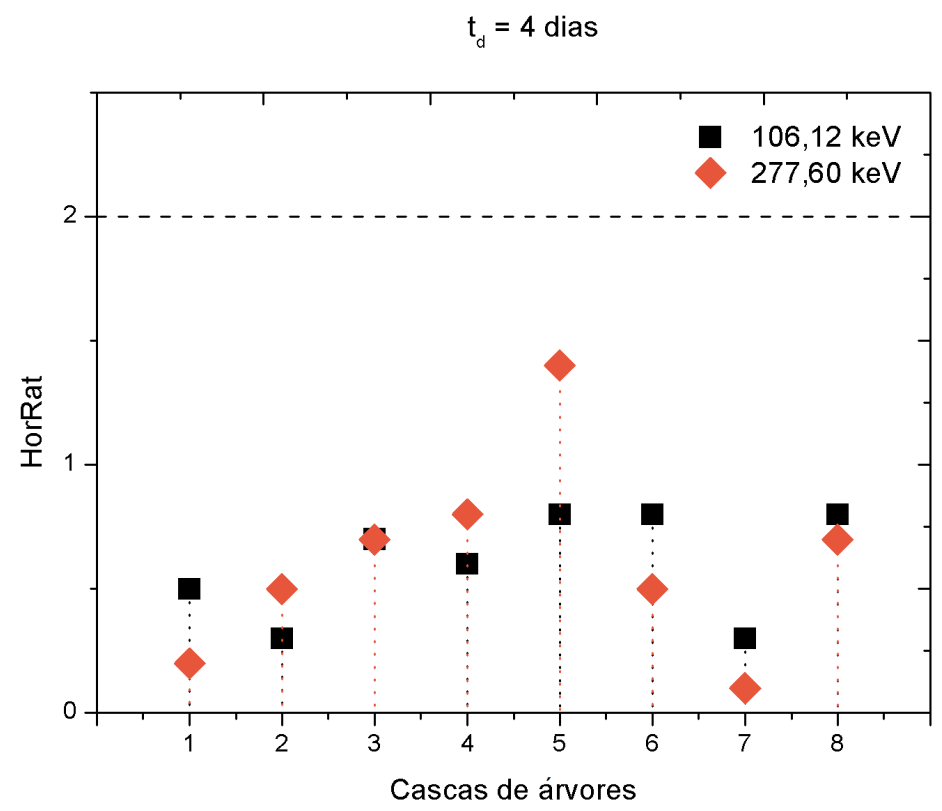

Fonte: Autora da dissertação. 


\subsection{Resultados da determinação de urânio em amostras de bromélias}

Cinco amostras de bromélias tiveram suas frações mássicas de U determinadas por meio dos procedimentos de INAA e ENAA de curta duração e INAA e ENAA de longa duração. As médias das frações mássicas de U (M) são apresentadas com as incertezas expandidas (u), os valores de desvio padrão relativo (DPR), os valores de HorRat e os limites de detecção (LD) e quantificação (LQ). Os valores extremos (outliers) foram removidos dos conjuntos de dados aplicando o teste de Grubbs com nível de significância de 0,05. Os resultados individuais obtidos nas determinações de U nas amostras de bromélias estão apresentados nas tabelas do Apêndice $\mathrm{C}$ dessa dissertação.

\subsubsection{Irradiações de curta duração de amostras de bromélias}

\subsubsection{Análise por ativação com nêutrons térmicos e epitérmicos de curta duração}

As frações mássicas de U determinadas nas amostras de bromélias por ENAA de curta duração usando o pico de 74,66 keV do ${ }^{239} \mathrm{U}$ são apresentadas na Tabela 20. Nessas amostras, não foi possível determinar U por INAA de curta duração, pois suas frações mássicas foram menores do que seus limites de detecção. Por ENAA de curta duração, as frações mássicas de U foram quantificadas em três das cinco amostras propostas para análise e variaram de $49 \pm 61 \mathrm{ng}^{-1}$ a $88 \pm 37 \mathrm{ng} \mathrm{g}^{-1}$. Os valores de HorRat dos resultados que foram apresentados na Tabela 20 e na Figura 40 indicaram boa precisão dos dados obtidos para as três amostras de bromélias. Nessa figura, pode-se observar que os valores foram menores que 2, indicando que os resultados são precisos.

Figura 40 - Valores de HorRat para as frações mássicas de U nas amostras de bromélias obtidas por ENAA de curta duração.

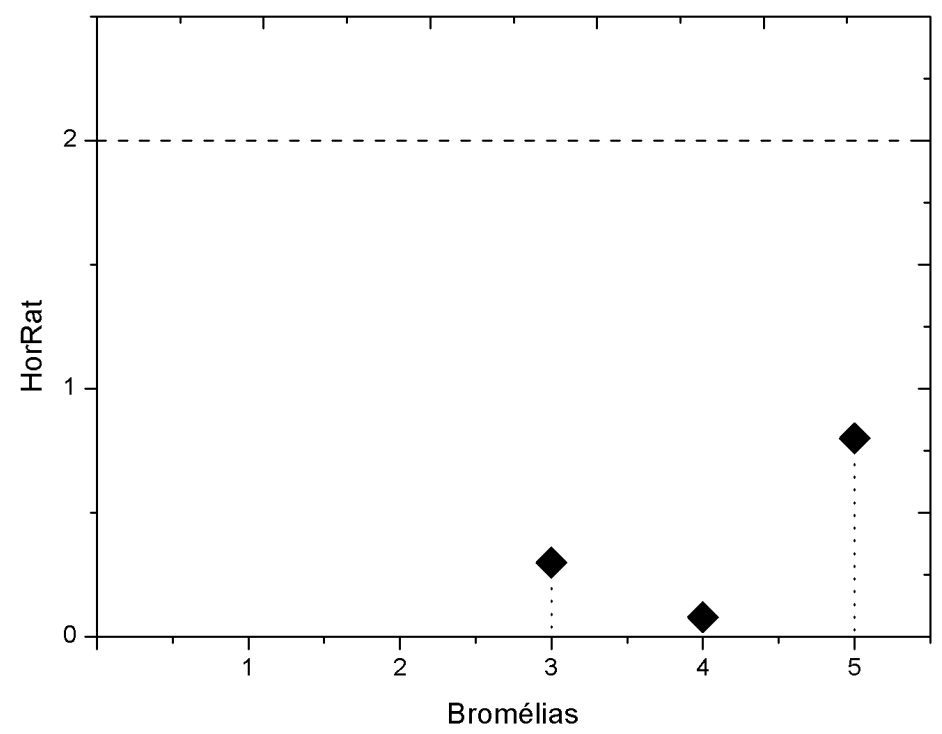

Fonte: Autora da dissertação. 
Tabela 20 - Frações mássicas de U (ng g $\left.{ }^{-1}\right)$ em amostras de bromélias obtidas por INAA e ENAA de curta duração.

\begin{tabular}{|c|c|c|c|c|c|c|}
\hline Bromélias & Técnica & $\mathbf{M} \pm \mathbf{u}(\mathbf{n})$ & DPR, \% & HorRat & LD & LQ \\
\hline \multirow{2}{*}{1} & ENAA & $<102$ & \multicolumn{2}{|c|}{-} & 102 & 311 \\
\hline & INAA & $<358$ & \multicolumn{2}{|c|}{-} & 358 & 1089 \\
\hline \multirow{2}{*}{2} & ENAA & $<222$ & \multicolumn{2}{|c|}{-} & 222 & 674 \\
\hline & INAA & $<353$ & \multicolumn{2}{|c|}{-} & 353 & 1071 \\
\hline \multirow{2}{*}{3} & ENAA & $88 \pm 37(4)$ & 7,0 & 0,3 & 38 & 115 \\
\hline & INAA & $<293$ & \multicolumn{2}{|c|}{-} & 293 & 892 \\
\hline \multirow{2}{*}{4} & ENAA & $49 \pm 61(4)^{*}$ & 2,0 & 0,08 & 26 & 78 \\
\hline & INAA & $<323$ & \multicolumn{2}{|c|}{-} & 323 & 999 \\
\hline \multirow{2}{*}{5} & ENAA & $70 \pm 46(4)$ & 19,6 & 0,8 & 32 & 98 \\
\hline & INAA & $<344$ & \multicolumn{2}{|c|}{-} & 344 & 1047 \\
\hline
\end{tabular}

M - Média aritmética; $\mathrm{u}$ - Incerteza expandida com $\mathrm{k}=2$ e nível de significância de 0,05 ; n - Número de determinações; DPR - Desvio padrão relativo; LD - Limite de detecção; LQ - Limite de quantificação; * - Resultados obtidos na segunda contagem. Fonte: Autora da dissertação.

\subsubsection{Irradiações de longa duração de amostras de bromélias}

\subsubsection{Análise por ativação com nêutrons térmicos de longa duração}

As médias das frações mássicas de U determinadas nas amostras de bromélias por INAA de longa duração, apresentadas na Tabela 21, foram obtidas usando os picos de $106,12 \mathrm{keV}$ e $277,60 \mathrm{keV}$ do ${ }^{239} \mathrm{~Np}$ para o tempo de decaimento de 7 dias. Não foi possível realizar a quantificação de U pelo pico de $277,60 \mathrm{keV}$ em três amostras devido ao problema da interferência espectral. As frações mássicas de U variaram de $38 \pm 15 \mathrm{ng} \mathrm{g}^{-1} \mathrm{a}$ $101 \pm 7 \mathrm{ng} \mathrm{g}^{-1}$ e as incertezas expandidas associadas aos resultados foram menores do que as obtidas por ENAA de curta duração. Os valores de limites de detecção e de quantificação foram inferiores aos obtidos na ENAA de curta duração. Além disso, os limites obtidos para o pico de 106,12 keV foram inferiores aos obtidos para 277,60 keV. Com relação à precisão dos resultados, os valores de HorRat foram menores que 2 (vide Figura 41), garantindo a reprodutibilidade do conjunto de dados. 
Tabela 21 - Frações mássicas de $\mathrm{U}\left(\mathrm{ng} \mathrm{g}^{-1}\right)$ em amostras de bromélias obtidas por INAA de longa duração com tempo de decaimento de 7 dias.

\begin{tabular}{|c|c|c|c|c|c|c|}
\hline Bromélias & $\begin{array}{c}\text { Energia dos } \\
\text { raios gama } \\
(\mathrm{keV})\end{array}$ & $\mathbf{M} \pm \mathbf{u}(\mathbf{n})$ & DPR, \% & HorRat & LD & LQ \\
\hline \multirow{2}{*}{1} & 106,12 & $44 \pm 16(3)$ & 11,0 & 0,4 & 14 & 41 \\
\hline & 277,60 & $* *$ & \multicolumn{2}{|c|}{-} & 25 & 69 \\
\hline \multirow{2}{*}{2} & 106,12 & $38 \pm 15(3)$ & 4,1 & 0,2 & 13 & 39 \\
\hline & 277,60 & $* *$ & \multicolumn{2}{|c|}{-} & 21 & 66 \\
\hline \multirow{2}{*}{3} & 106,12 & $101 \pm 7(3)$ & 27,2 & 1,2 & 8 & 24 \\
\hline & 277,60 & $* *$ & \multicolumn{2}{|c|}{-} & 16 & 48 \\
\hline \multirow{2}{*}{4} & 106,12 & $44 \pm 8(2)$ & 37,6 & 1,5 & 7 & 21 \\
\hline & 277,60 & $52 \pm 19(2)$ & 28,4 & 1,1 & 14 & 43 \\
\hline \multirow{2}{*}{5} & 106,12 & $91 \pm 10(3)$ & 30,7 & 1,3 & 12 & 37 \\
\hline & 277,60 & $66 \pm 16(3)$ & 19,0 & 0,8 & 22 & 67 \\
\hline
\end{tabular}

M - Média aritmética; $\mathrm{u}$ - Incerteza expandida com $\mathrm{k}=2$ e nível de confiança de $95 \% ; \mathrm{n}$ Número de determinações; DPR - Desvio padrão relativo; LD - Limite de detecção; LQ Limite de quantificação; ** - Não calculado devido às interferências espectrais. Fonte: Autora da dissertação.

Figura 41 - Valores de HorRat para as frações mássicas de U nas amostras de bromélias obtidas por INAA de longa duração.

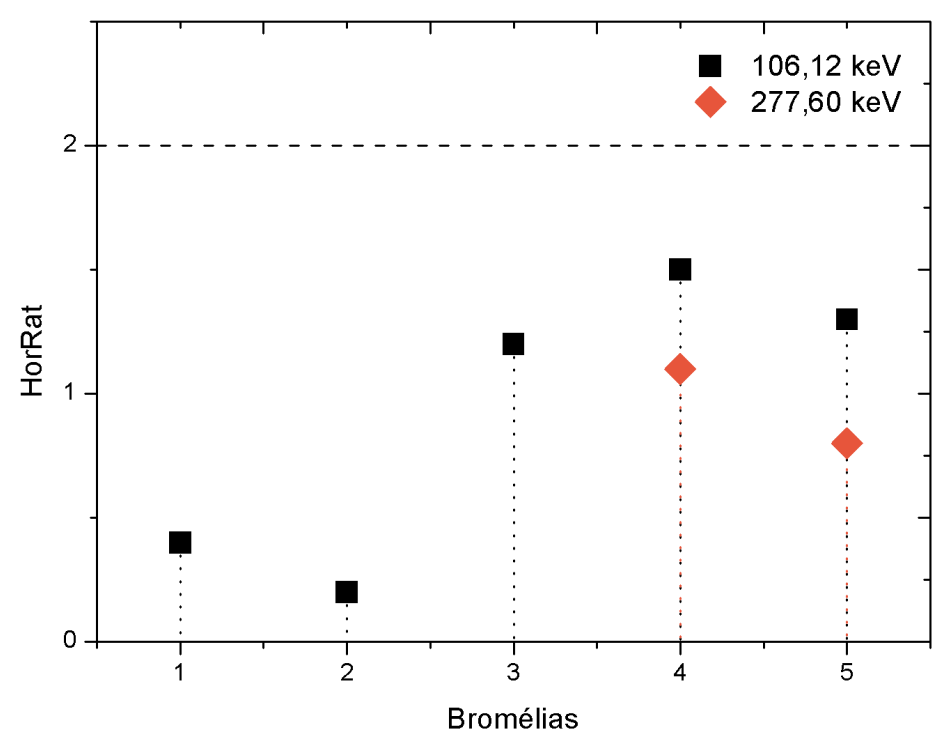

Fonte: Autora da dissertação. 


\subsubsection{Análise por ativação com nêutrons epitérmicos de longa duração}

Na Tabela 22 são apresentadas as médias das determinações de U em amostras de bromélias por ENAA de longa duração obtidos usando os picos de 106,12 keV e 277,60 keV do ${ }^{239} \mathrm{~Np}$ para dois tempos de decaimento. As frações mássicas de U nessas amostras variaram de $35 \pm 7 \mathrm{ng} \mathrm{g}^{-1}$ a $63 \pm 8 \mathrm{ng} \mathrm{g}^{-1}$ nas medições feitas com 2 dias de decaimento e de $34 \pm 16 \mathrm{ng} \mathrm{g}^{-1}$ a $80 \pm 2 \mathrm{ng} \mathrm{g}^{-1}$ com 4 dias de decaimento. A reprodutibilidade dos resultados obtidos nas amostras de bromélias foi demonstrada pelos valores de DPR e de HorRat, conforme os dados da Tabela 22 e das Figuras 42 e 43. Os limites de detecção e de quantificação obtidos nas análises de bromélias foram menores para o pico de $106,12 \mathrm{keV}$ quando comparado com os obtidos para o pico de 277,60 keV. Na ENAA de longa duração, as incertezas e os valores de limite de detecção e de quantificação foram inferiores ou similares aos obtidos por INAA de longa duração.

Figura 42 - Valores de HorRat para as frações mássicas de U nas amostras de bromélias obtidas por ENAA de longa duração com 2 dias de decaimento.

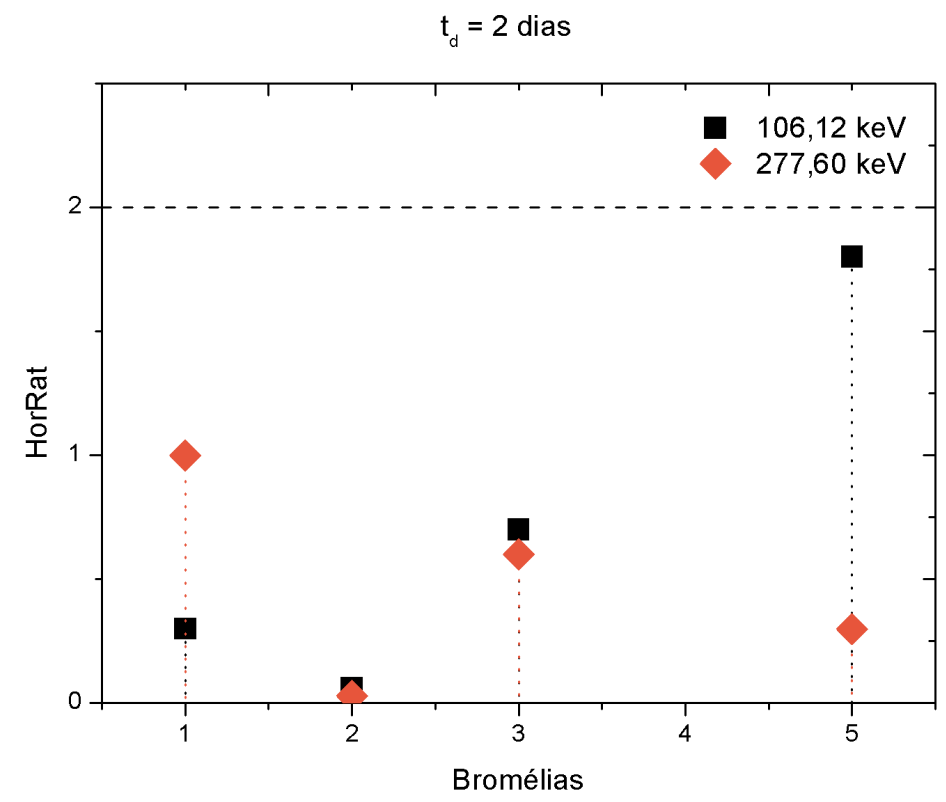

Fonte: Autora da dissertação. 
Tabela 22 - Frações mássicas de $\mathrm{U}\left(\mathrm{ng} \mathrm{g}^{-1}\right)$ em amostras de bromélias obtidas por ENAA de longa duração.

\begin{tabular}{|c|c|c|c|c|c|c|c|c|c|}
\hline \multirow{2}{*}{ Bromélias } & \multirow{2}{*}{ Energia dos raios gama (keV) } & \multicolumn{3}{|c|}{$t_{d}=\mathbf{2} \mathbf{d}$} & \multicolumn{3}{|c|}{$t_{d}=\mathbf{4} \mathbf{d}$} & \multirow{2}{*}{ LD } & \multirow{2}{*}{ LQ } \\
\hline & & $\mathbf{M} \pm \mathbf{u}(\mathbf{n})$ & DPR, \% & HorRat & $\mathbf{M} \pm \mathbf{u}(\mathbf{n})$ & DPR, \% & HorRat & & \\
\hline \multirow{2}{*}{1} & 106,12 & $45 \pm 12(4)$ & 9,0 & 0,3 & $46 \pm 6(4)$ & 5,1 & 0,2 & 11 & 32 \\
\hline & 277,60 & $41 \pm 33(4)$ & 27,9 & 1,0 & $43 \pm 13(4)$ & 5,8 & 0,2 & 23 & 71 \\
\hline \multirow{2}{*}{2} & 106,12 & $35 \pm 7(3)$ & 1,6 & 0,06 & $36 \pm 17(4)$ & 27,2 & 1,0 & 5 & 15 \\
\hline & 277,60 & $37 \pm 16(4)$ & 0,8 & 0,03 & $34 \pm 16(3)$ & 1,6 & 0,06 & 12 & 37 \\
\hline \multirow{2}{*}{3} & 106,12 & $63 \pm 8$ & 17,6 & 0,7 & $80 \pm 2(2)$ & 4,0 & 0,2 & 11 & 33 \\
\hline & 277,60 & $62 \pm 25(4)$ & 14,6 & 0,6 & $73 \pm 24(4)$ & 16,3 & 0,7 & 25 & 77 \\
\hline \multirow{2}{*}{4} & 106,12 & $46 \pm 10(1)$ & $=$ & & $52 \pm 5(4)$ & 9,3 & 0,4 & 9 & 26 \\
\hline & 277,60 & $50 \pm 21(1)$ & $=$ & & $50 \pm 11(4)$ & 7,4 & 0,3 & 21 & 65 \\
\hline \multirow{2}{*}{5} & 106,12 & $60 \pm 6(4)$ & 44,2 & 1,8 & $70 \pm 6(2)$ & 0,8 & 0,03 & 9 & 28 \\
\hline & 277,60 & $61 \pm 18$ & 6,6 & 0,3 & $68 \pm 14(3)$ & 25,1 & 1,0 & 21 & 64 \\
\hline
\end{tabular}

M - Média aritmética; $\mathrm{u}$ - Incerteza expandida com $\mathrm{k}=2$ e nível de significância de 0,$05 ; \mathrm{n}$ - Número de determinações; DPR - Desvio padrão relativo; LD - Limite de detecção; LQ - Limite de quantificação; * - Não calculado devido à única determinação; Fonte: Autora da dissertação. 
Figura 43 - Valores de HorRat para as frações mássicas de U nas amostras de bromélias obtidas por ENAA de longa duração com 4 dias de decaimento.

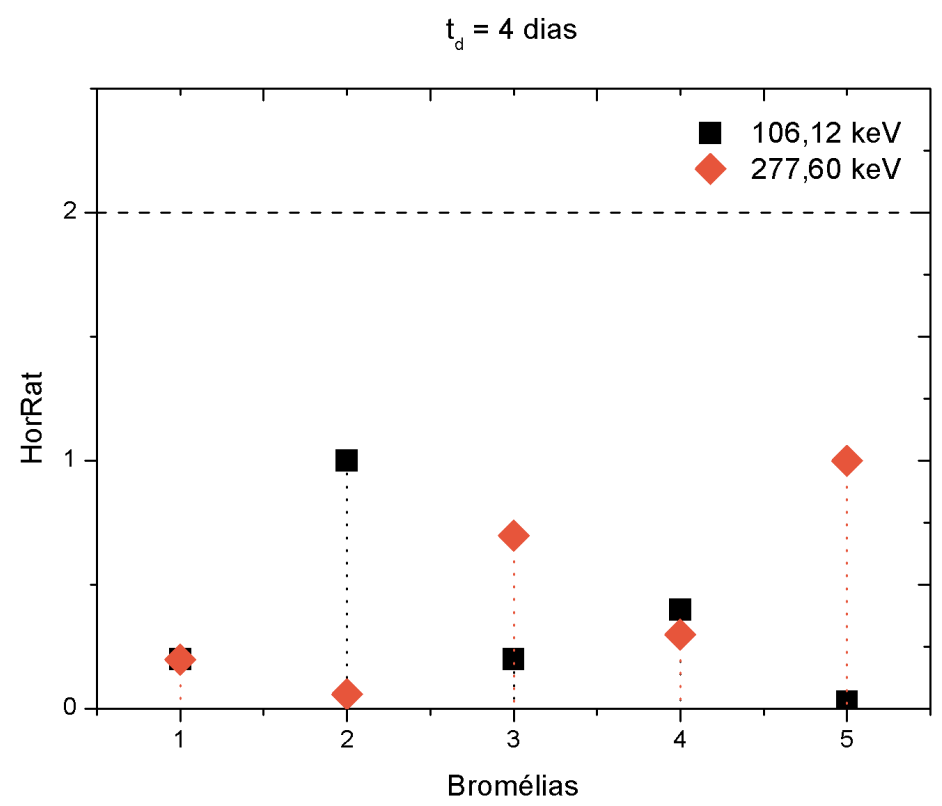

Fonte: Autora da dissertação.

\subsection{Comparação entre resultados das frações mássicas de urânio obtidas em amos- tras de biomonitores por diferentes procedimentos de análise por ativação com nêutrons}

Para verificar se há diferença entre os resultados obtidos por meio dos procedimentos INAA e ENAA de curta e longa duração foram realizadas comparações entre as frações mássicas médias de U obtidas nas amostras de biomonitores. Como não foi possível realizar a quantificação de U nas amostras de cascas de árvores e bromélias por INAA de curta duração, apenas os limites de detecção obtidos por esta técnica serão discutidos nesta parte do trabalho.

As comparações entre os resultados foram realizadas por meio da aplicação do teste estatístico de análise de variância (ANOVA) e nos casos em que houve diferença entre as médias, foi utilizado o teste de Tukey para identificar como se diferiram estes conjuntos de dados. As médias das frações mássicas de U obtidas para cada amostra foram apresentadas em gráficos "box plots" para melhor visualização dos dados. Também foram comparados os valores de limites de detecção obtidos nas análises dos MRCs e nas amostras de biomonitores pelos quatro procedimentos estudados neste trabalho. 


\subsubsection{Aplicação da ANOVA às médias das frações mássicas de urânio obtidas em amos- tras de biomonitores por diferentes procedimentos de análise por ativação com nêutrons}

Foi utilizada a análise de variância, a ANOVA, como abordagem estatística para verificar se existiam diferenças significativas entre as médias das frações mássicas de $\mathrm{U}$ obtidas pelos diferentes procedimentos em cada amostra analisada. A ANOVA foi utilizada para testar a hipótese de igualdade entre as médias, sendo essa a hipótese nula. No caso em que a hipótese nula foi rejeitada, aceitou-se a hipótese alternativa de que pelo menos uma das médias era diferente. A partir disso, para determinar como diferiam as médias foi utilizado o teste de Tukey. Dessa maneira, a ANOVA e o teste de Tukey foram aplicados nos resultados das amostras de cascas de árvores e os dados obtidos nessas análises estão apresentados na Tabela 23.

Os resultados da ANOVA indicaram que cinco das oito amostras de cascas de árvores apresentaram diferenças significativas entre as frações mássicas de U obtidas com ENAA de curta duração e INAA e ENAA de longa duração, com nível de significância de 0,05 . Nesses casos os valores de $\mathrm{p}$ foram menores que o nível de significância e os valores de $\mathrm{F}$ foram maiores que o $\mathrm{F}$ crítico $\left(F_{c}\right)$, mostrando que há diferenças entre as populações comparadas.

Os resultados do teste de Tukey demonstraram como as médias diferiam entre si, e nos casos das amostras 1 e 7, o procedimento INAA de longa duração gerou médias diferentes daquelas obtidas por ENAA de curta duração. Nas amostras 3, 6 e 8 as diferenças foram entre os procedimentos INAA e ENAA de longa duração e a ENAA de curta duração foi compatível com as outras duas. Para melhor visualização desses resultados, foram elaborados os gráficos "box plots" das frações mássicas de U obtidas para ENAA de curta duração e INAA e ENAA de longa duração. Esses gráficos estão apresentados nas Figuras 44 e 45.

Nessas figuras, pode-se observar que os "box plots" obtidos na ENAA de curta duração e INAA de longa duração não apresentam quartis bem definidos devido ao baixo número de determinações. Entretanto, esses gráficos mostram como ocorreu a dispersão dos dados amostrais. A partir disso, observa-se que os resultados obtidos com o procedimento INAA de longa duração foram, em grande parte, dispersos e imprecisos.

Associando isso ao resultado do teste de Tukey, em que a INAA de longa duração está relacionada à todas diferenças encontradas entre as médias, pode-se afirmar que este procedimento não fornece resultados confiáveis para a faixa de fração mássica de U presente em amostras de cascas de árvores.

Da mesma forma em que foi feito com as cascas de árvores, antes da aplicação da ANOVA, as amostras de bromélias foram submetidas ao teste Shapiro-Wilk para normalidade a um nível de significância 0,05 . Os resultados obtidos na aplicação dos testes da ANOVA e 
Tabela 23 - Comparação entre os resultados das amostras de cascas de árvores obtidos pela ENAA de curta duração e INAA e ENAA de longa duração realizada pela análise de variância (ANOVA) e pelo teste de Tukey.

\begin{tabular}{cccccc|ccc}
\hline \multirow{2}{*}{ Amostra } & \multicolumn{2}{c}{ ANOVA } & \multicolumn{2}{c|}{$F_{0,05}$} & \multicolumn{3}{c}{ Teste de Tukey $(\mathrm{M} \pm \mathrm{DP})$} \\
\cline { 2 - 9 } & Valor de p & $\mathbf{F}$ & $v_{1}$ & $v_{2}$ & $\mathbf{F}_{c}$ & $\begin{array}{c}\text { ENAA de } \\
\text { curta duração }\end{array}$ & $\begin{array}{c}\text { INAA de } \\
\text { longa duração }\end{array}$ & $\begin{array}{c}\text { ENAA de } \\
\text { longa duração }\end{array}$ \\
\hline 1 & $0,001024^{*}$ & 10,34 & 2 & 18 & 3,55 & $99,3 \pm 0,1^{a}$ & $167 \pm 42^{b}$ & $93 \pm 2^{a}$ \\
2 & 0,05438 & 3,38 & 2 & 20 & 3,49 & $83 \pm 4^{a}$ & $81 \pm 10^{a}$ & $94 \pm 2^{a}$ \\
3 & $0,01857^{*}$ & 4,95 & 2 & 19 & 3,52 & $133 \pm 1^{a b}$ & $110 \pm 4^{a}$ & $145 \pm 5^{b}$ \\
4 & 0,3741 & 1,036 & 2 & 19 & 3,52 & $130 \pm 13^{a}$ & $122 \pm 17^{a}$ & $139 \pm 4^{a}$ \\
5 & 0,3915 & 0,999 & 2 & 15 & 3,68 & $176 \pm 9^{a}$ & $149 \pm 38^{a}$ & $193 \pm 14^{a}$ \\
6 & $0,0001556^{*}$ & 14,03 & 2 & 20 & 3,49 & $588 \pm 16^{a b}$ & $502 \pm 21^{a}$ & $681 \pm 16^{b}$ \\
7 & $0,0006574^{*}$ & 10,81 & 2 & 20 & 3,49 & $206 \pm 2^{a}$ & $156 \pm 24^{b}$ & $202 \pm 3^{a}$ \\
8 & $0,01678^{*}$ & 5,049 & 2 & 20 & 3,49 & $583 \pm 34^{a b}$ & $454 \pm 17^{a}$ & $623 \pm 23^{b}$ \\
\hline
\end{tabular}

* - Valores de p menores que o nível de significância de 0,$05 ; F_{0,05}$ - Estatística $\mathrm{F}$ para o nível de significância de 0,$05 ; v_{1}$ e $v_{2}$ - Graus de liberdade; $F_{c}$ - Valor crítico de F; Teste de Tukey Letras diferentes indicam que as médias diferem entre si com 0,05 nível de significância de 0,05; M - Média aritmética dos resultados obtidos para ambos os picos e tempos de contagem; DP - Desvio padrão. Fonte: Autora da dissertação.

de Tukey estão apresentados na Tabela 24.

A fração mássica de U não pôde ser determinada em duas amostras de bromélias por ENAA de curta duração e, nesses casos, a comparação foi feita apenas entre dois procedimentos. A aplicação da ANOVA indicou que apenas uma das amostras de bromélias apresentou diferença entre as médias das frações mássicas de U. Nesse caso o valor de $p$ foi menor que o nível de significância e o valor de $\mathrm{F}$ foi maior que o $\mathrm{F}$ crítico $\left(F_{c}\right)$, apontando que existe diferença entre as populações comparadas.

Os resultados do teste de Tukey foram apresentados na Tabela 24, sendo que letras distintas indicam que as médias referentes aos procedimentos analíticos são diferentes a um nível de 0,05 de significância. Os gráficos "box plots" das médias das frações mássicas de U obtidas para ENAA de curta duração e INAA e ENAA de longa duração estão apresentados na Figura 46. Os "box plots" das médias das frações mássicas de U obtidas pelos procedimentos ENAA de curta duração e INAA de longa duração não apresentam quartis bem definidos devido ao baixo número de determinações, mas mostram como ocorreu a dispersão dos dados amostrais.

De forma semelhante ao observado com as cascas de árvores, os resultados obtidos pela INAA de longa duração apresentaram resultados dispersos e imprecisos. Além disso, o teste de Tukey mostrou que a INAA de longa duração está relacionada a diferença encontrada entre as médias das frações mássicas de U na amostra 3. Logo, conclui-se que este procedimento também não produziu resultados confiáveis para a faixa de fração mássica de $U$ 
presente nas amostras de bromélias.

Tabela 24 - Comparação entre os resultados das amostras de bromélias obtidos pela ENAA de curta duração e INAA e ENAA de longa duração realizada pela análise de variância (ANOVA) e pelo teste de Tukey.

\begin{tabular}{cccccc|ccc}
\hline \multirow{2}{*}{ Amostra } & \multicolumn{2}{c}{ ANOVA } & \multicolumn{2}{c|}{$F_{0,05}$} & \multicolumn{3}{c}{ Teste de Tukey $(\mathrm{M} \pm \mathrm{DP})$} \\
\cline { 2 - 9 } & Valor de p & $\mathbf{F}$ & $v_{1}$ & $v_{2}$ & $\mathbf{F}_{c}$ & $\begin{array}{c}\text { ENAA de } \\
\text { curta duração }\end{array}$ & $\begin{array}{c}\text { INAA de } \\
\text { longa duração }\end{array}$ & $\begin{array}{c}\text { ENAA de } \\
\text { longa duração }\end{array}$ \\
\hline 1 & 0,864 & 0,03046 & 1 & 14 & 4,60 & $* *$ & $44 \pm 3^{a}$ & $44 \pm 2^{a}$ \\
2 & 0,6347 & 0,2366 & 1 & 13 & 4,66 & $* *$ & $38 \pm 1^{a}$ & $35 \pm 2^{a}$ \\
3 & $0,001809^{*}$ & 9,368 & 2 & 17 & 4,45 & $88 \pm 3^{a b}$ & $101 \pm 16^{a}$ & $67 \pm 3^{b}$ \\
4 & 0,7819 & 0,2512 & 2 & 14 & 3,74 & $49,4 \pm 0,6^{a}$ & $48 \pm 7^{a}$ & $51 \pm 1^{a}$ \\
5 & 0,4862 & 0,7479 & 2 & 20 & 3,49 & $70 \pm 7^{a}$ & $78 \pm 10^{a}$ & $66 \pm 5^{a}$ \\
\hline
\end{tabular}

* - Valores de p menores que o nível de significância de 0,$05 ; F_{0,05}$ - Estatística $\mathrm{F}$ para o nível de significância de 0,$05 ; v_{1}$ e $v_{2}$ - Graus de liberdade; $F_{c}$ - Valor crítico de F; Teste de Tukey Letras diferentes indicam que as médias diferem entre si com nível de significância de 0,05 ; M - Média aritmética dos resultados obtidos para ambos os picos e tempos de contagem; DP Desvio padrão; ** - Indica que o U não foi determinado. Fonte: Autora da dissertação.

Os resultados das determinações de $\mathrm{U}$ em amostras de cascas de árvores não puderam ser comparados com valores presentes na literatura pois estes são escassos. Os trabalhos disponíveis utilizam diferentes espécies arbóreas coletadas em localidades com características distintas da presente região de coleta, o que impediu que alguma comparação pudesse ser feita.

Em relação aos resultados das determinações de U em amostras de bromélias, o trabalho de Figueiredo et al. (2007) analisou amostras de Tillandsia usneoides L. expostas na região metropolitana de São Paulo. Neste estudo, as frações mássicas de U determinadas variaram de $19 \pm 8 \mathrm{ng} \mathrm{g}^{-1}$ a $134 \pm 9 \mathrm{ng} \mathrm{g}^{-1}$. Dessa maneira, os resultados apresentados no presente trabalho estão dentro da faixa de fração mássica encontrada em Figueiredo et al. (2007). 
Figura 44 - Representação "box plot" das frações mássicas de U nas amostras de cascas de árvores determinadas por ENAA de curta duração e INAA e ENAA de longa duração.

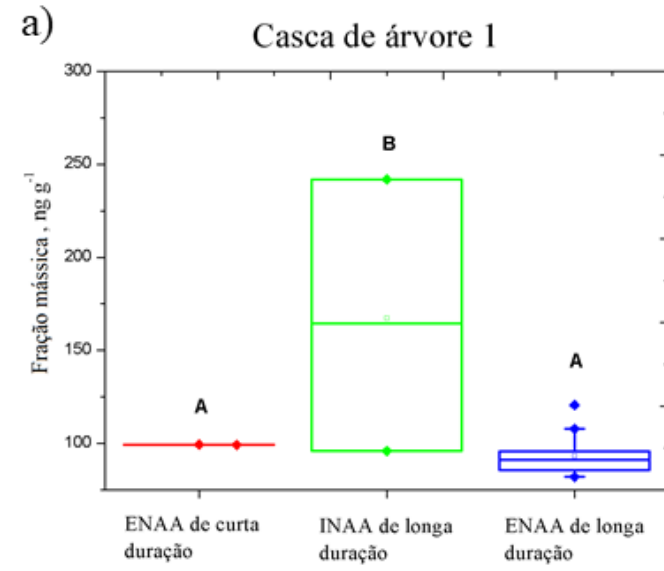

d)

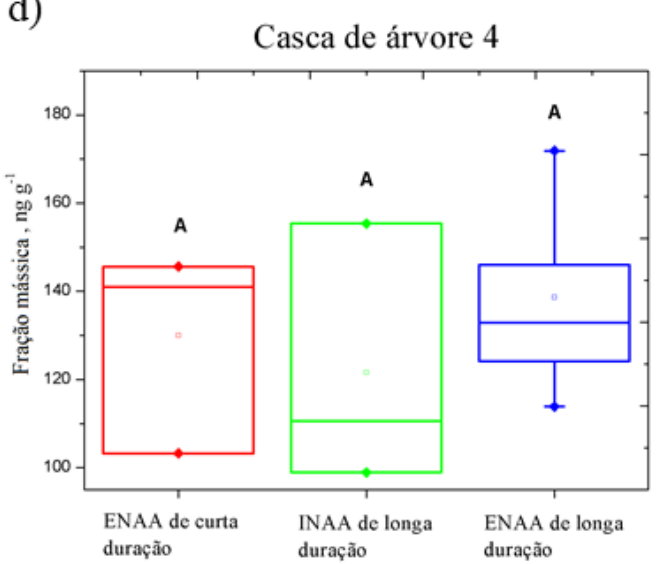

b)

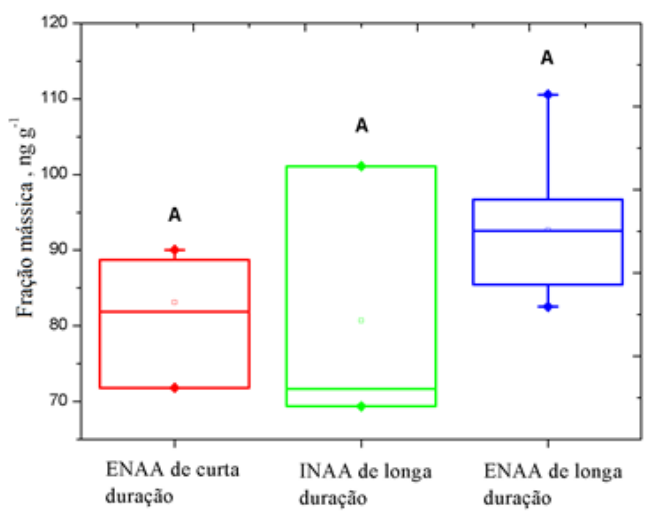

c) Casca de árvore 3

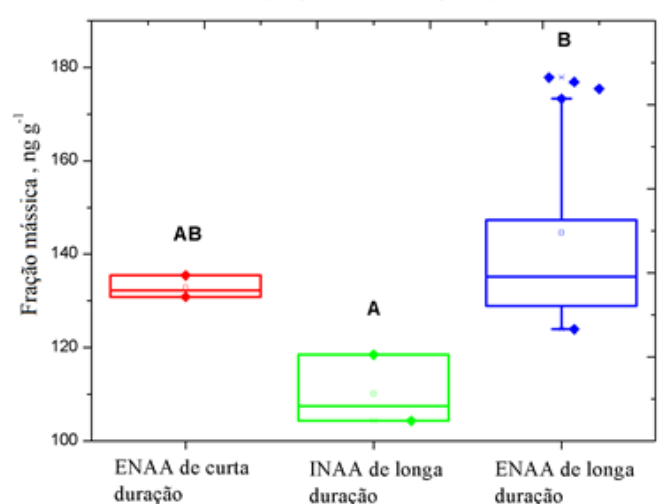

e)

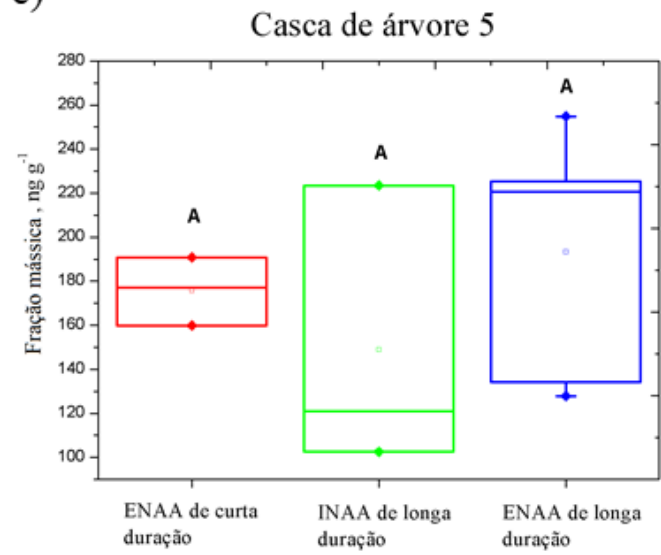

Os diagramas acompanhados de letras diferentes indicam que as médias diferem entre si pelo teste de Tukey com nível de significância 0,05. Fonte: Autora da dissertação. 
Figura 45 - Representação "box plot" das frações mássicas de U nas amostras de cascas de árvores determinadas por ENAA de curta duração e INAA e ENAA de longa duração.

a)

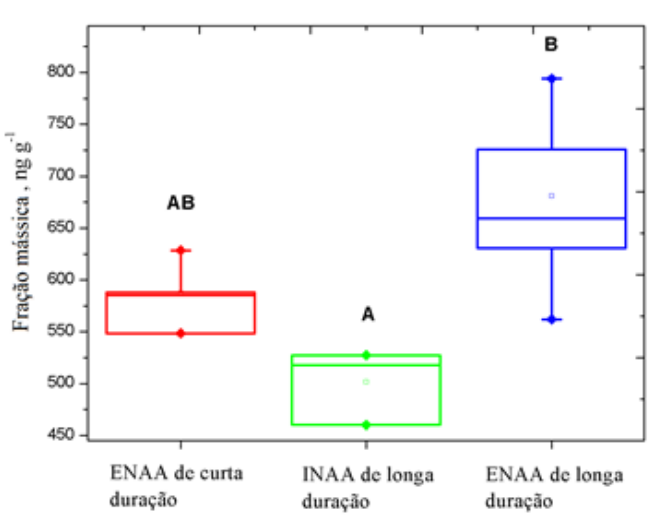

b)

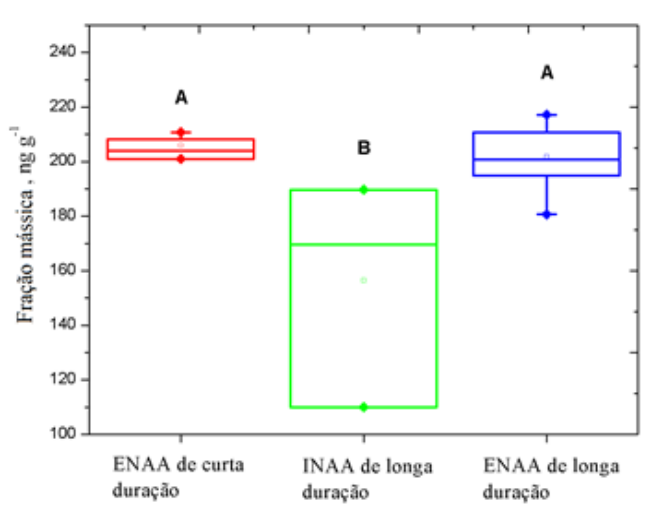

c)

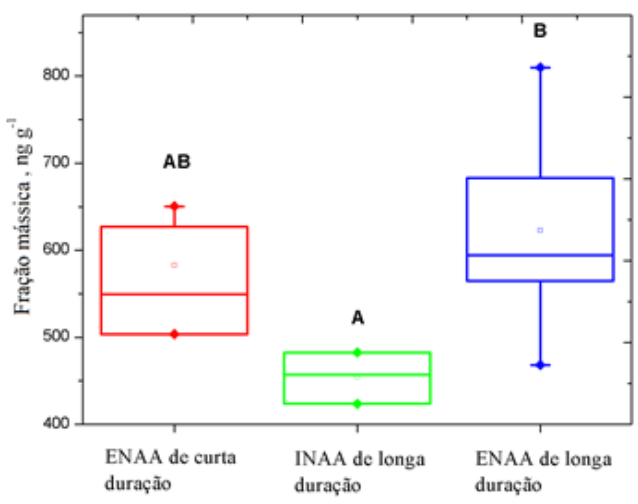

Os diagramas acompanhados de letras diferentes indicam que as médias diferem entre si pelo teste de Tukey com nível de significância 0,05. Fonte:

Autora da dissertação. 
Figura 46 - Representação "box plot" das frações mássicas de U em amostras bromélias determinadas por ENAA de curta duração e INAA e ENAA de longa duração.
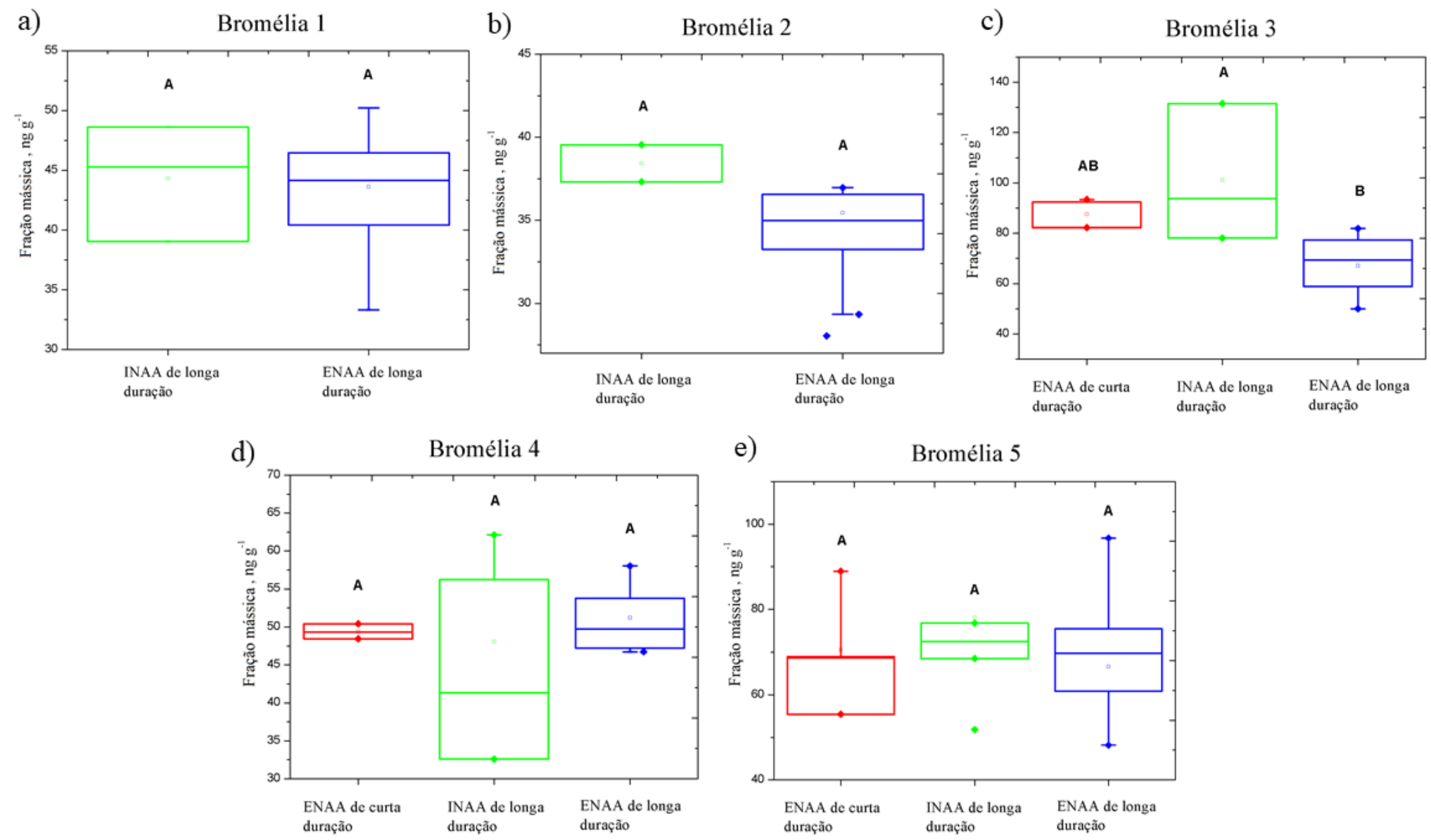

Os diagramas acompanhados de letras diferentes indicam que as médias diferem entre si pelo teste de Tukey com nível de significância 0,05. Fonte: 


\subsubsection{Comparação dos limites de detecção obtidos em materiais de referência certifi- cados e amostras por diferentes procedimentos}

Com o intuito de comparar os limites de detecção obtidos nas análises dos MRCs por INAA e ENAA de curta e longa duração foi elaborada a Figura 47. Nesta figura, podese verificar que estes limites dependem do procedimento de análise. Os procedimentos de curta duração por meio de irradiação térmica ou epitérmica apresentaram os maiores valores de limite de detecção. Com os procedimentos de longa duração, foram obtidos limites de detecção inferiores aos de curta duração. Devido a maior abundância de raios gamas do pico de 106,12 keV (27,2\%) em relação ao pico de 277,60 keV (14,4\%), o primeiro apresentou menores limites de detecção (LBNL, 2018).

Figura 47 - Limites de detecção de U obtidos na análise de materiais de referência certificados.

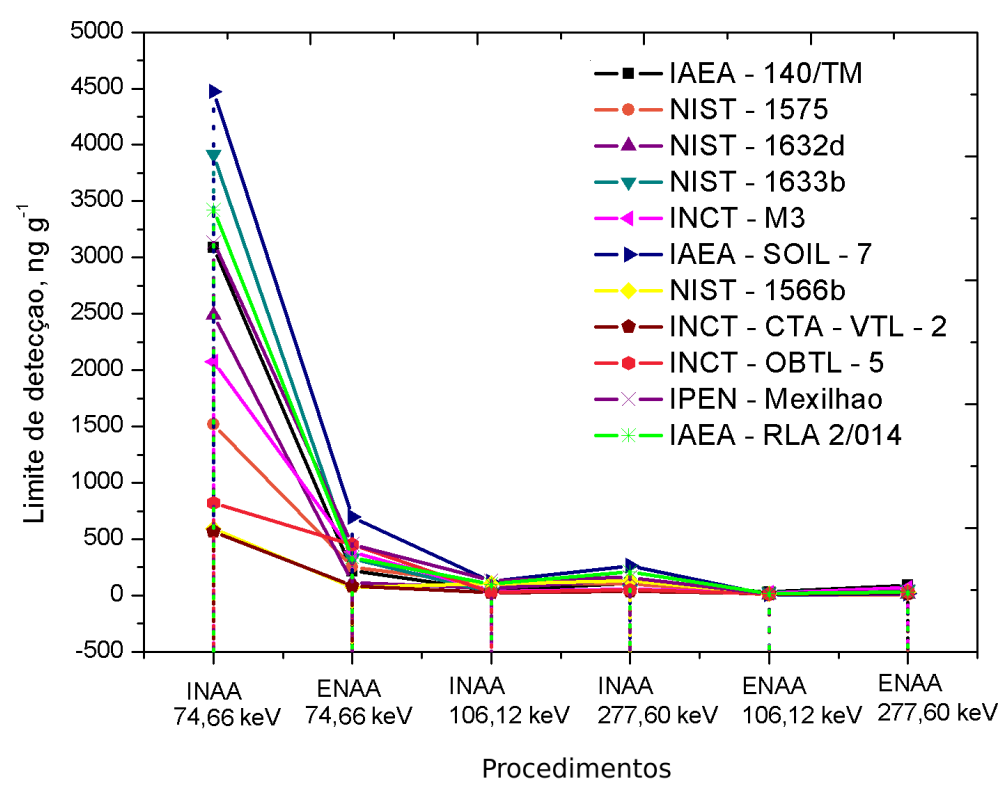

Fonte: Autora da dissertação.

Os limites de detecção obtidos nas análises das cascas de árvores por INAA e ENAA de curta e longa duração são apresentados na Figura 48. Assim como nos MRCs, os limites de detecção obtidos por meio da ENAA de curta duração foram menores que os obtidos por INAA de curta duração, o que possibilitou a quantificação de U nas cascas de árvores somente por ENAA de curta duração. Os limites de detecção foram ainda menores para os procedimentos de INAA e ENAA de longa duração. Nas cascas de árvores, os procedimentos de longa duração resultaram, de forma geral, em limites de detecção da mesma ordem de grandeza dos obtidos nos MRCs.

Na Figura 49 estão apresentados os limites de detecção de U obtidos nas análises das amostras de bromélias. Com o uso da ENAA de curta duração, foram obtidos limites de 
detecção menores que os da INAA de curta duração, o que possibilitou a quantificação de U nas amostras de bromélias por este procedimento.

Figura 48 - Limites de detecção de U obtidos na análise de amostras cascas de árvores.

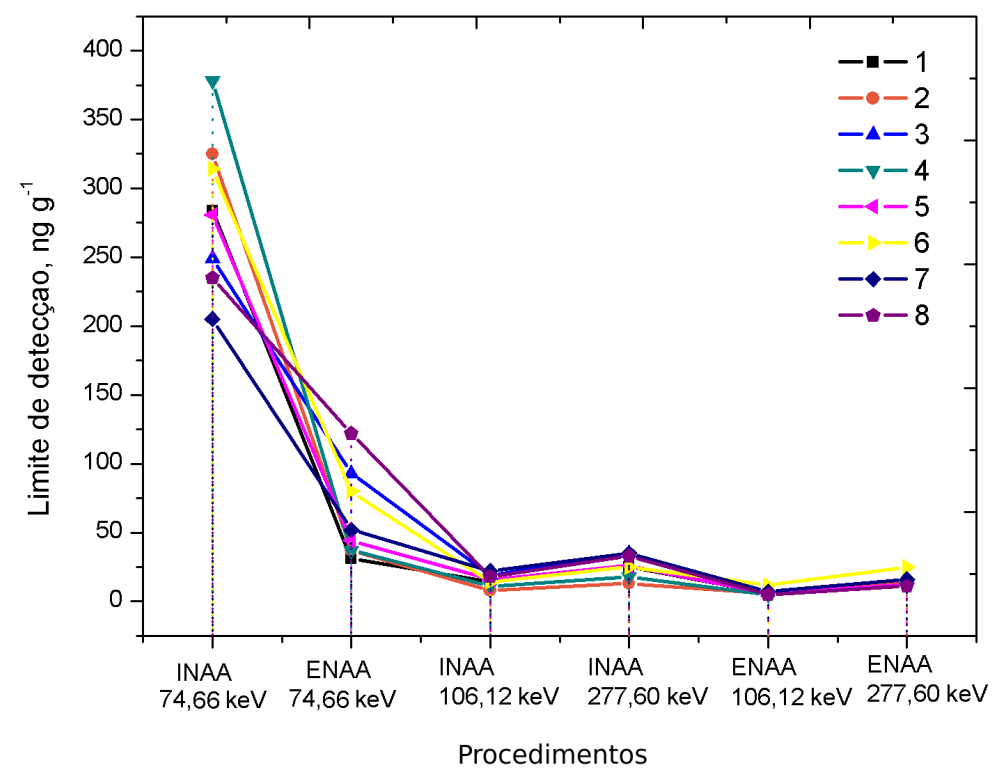

Fonte: Autora da dissertação.

Figura 49 - Limites de detecção de U obtidos na análise de amostras de bromélias.

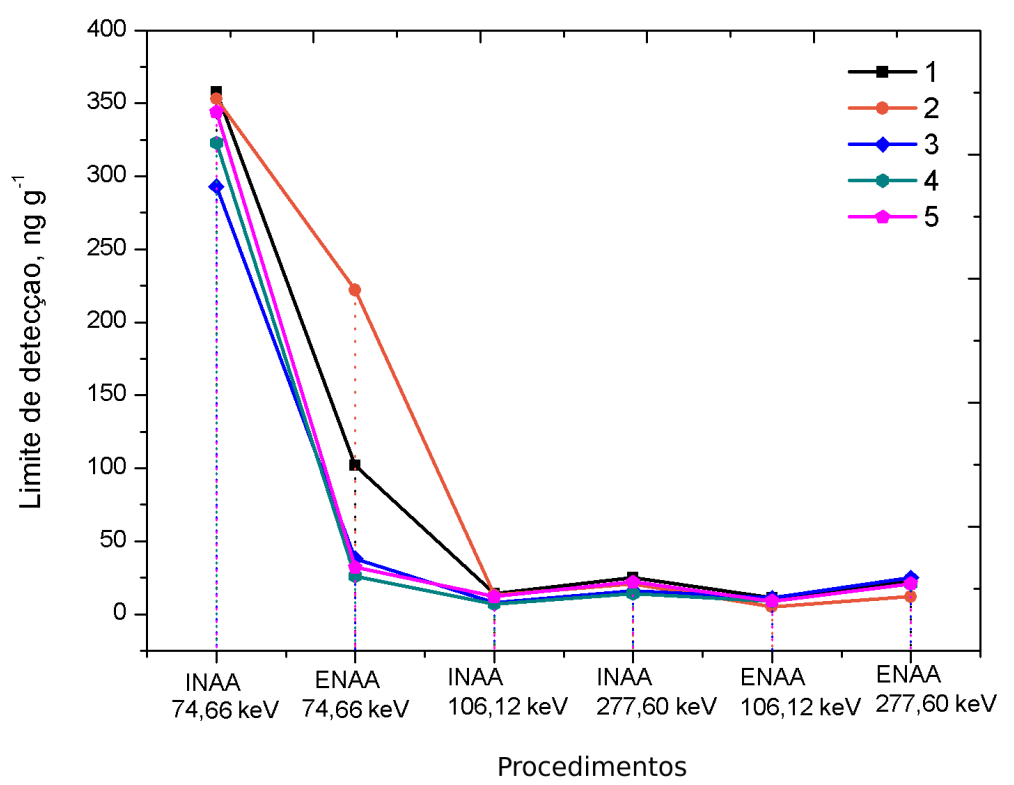

Fonte: Autora da dissertação.

Os limites de detecção obtidos por meio das irradiações de longa duração foram, de forma geral, inferiores aos das irradiações de curta duração. Nas irradiações de longa duração todos os limites de detecção foram da mesma ordem de grandeza. Nas amostras 
ambientais, foco deste trabalho, as irradiações de longa duração apresentaram valores menores de limites de detecção, em especial com a irradiação epitérmica, o que caracteriza esse procedimento como o mais indicado para a determinação em amostras com baixos teores de U. 


\section{CONCLUSÕES}

Neste trabalho foram determinadas as frações mássicas de urânio com suas incertezas nas análises de MRCs e amostras vegetais, aplicando os procedimentos de INAA e ENAA por meio de irradiações de longa e curta duração.

Nestas determinações da incerteza, os maiores valores foram observados nos resultados das irradiações de curta duração. Dentre os procedimentos de análise das amostras de casca de árvore por INAA e ENAA usando irradiações de longa e curta duração, a ENAA de longa duração apresentou menores valores de incerteza nos resultados devido, principalmente, à menor contribuição da incerteza da estatística de contagem.

Nas determinações de U nos envelopes de polietileno utilizados na irradiação de amostras e nas tiras de papel de filtro Whatman $\mathrm{N}^{\circ} 40$, usadas no preparo do padrão, este elemento não foi detectado tanto nas irradiações epitérmicas de longa duração quanto nas de curta duração. Com isso, pode-se concluir que a impureza de U nos envelopes e nas tiras de papel de filtro pode ser desprezada.

Os resultados das análises dos MRCs e dos biomonitores da poluição ambiental, pelos diferentes procedimentos de análise por ativação com nêutrons, permitiram concluir que a possibilidade de obter resultados da fração mássica de U exatos e precisos depende principalmente da composição e do teor do elemento na amostra.

Nas análises dos MRCs por meio de irradiações de curta duração, foi possível quantificar U em maior número de materiais pela ENAA do que pela INAA. Nas irradiações de longa duração, a ENAA também permitiu a obtenção de resultados em um maior número de MRCs. Com as irradiações térmicas, em geral, foram obtidos espectros de raios gama complexos devido à ativação de elementos presentes nas amostras. No caso das irradiações de longa duração, os radioisótopos formados interferiram na resolução dos picos de 106,12 keV e $277,60 \mathrm{keV}$ do ${ }^{239} \mathrm{~Np}$.

Nos MRCs em que o U pôde ser quantificado por meio da INAA e ENAA de curta duração, foram obtidos resultados com $\mathrm{IZ}$ scorel menores que 2 , indicando que irradiações de curta duração podem fornecer, de maneira rápida, resultados exatos. Já nas irradiações de longa duração, foi verificado que tanto a INAA quanto a ENAA apresentaram resultados satisfatórios com $\mathrm{IZ}$ scorel $\leq 2$.

A precisão dos resultados dos MRCs, avaliada pelos valores de HorRat, demonstrou que, em geral, os resultados são reprodutíveis, com valores de HorRat menores ou iguais a 2. As exceções foram os resultados obtidos por ENAA de longa duração para os MRCs IAEA-SOIL-7 e IPEN-Mexilhão, cujos valores de HorRat foram maiores que 2 nas medições realizadas com 9 dias de decaimento. Isto se deve às baixas taxas de contagem obtidas para 
essas amostras.

Os resultados das análises das amostras de cascas de árvores permitiram concluir que a ENAA de curta e longa duração podem ser aplicadas na determinação de U em amostras desse tipo de matriz. A reprodutibilidade destes resultados foi satisfatória pela avaliação dos DPRs e pelo valor de HorRat.

O U não pôde ser quantificado nas cascas de árvore por INAA de curta duração devido aos limites de detecção deste procedimento serem maiores que as suas frações mássicas neste tipo de matriz. O procedimento de INAA de longa duração não foi apropriado para a determinação de $\mathrm{U}$ em cascas de árvores devido a não reprodutibilidade dos dados e o problema de interferência espectral. A interferência gerada pela alta taxa de contagem do pico de $103,18 \mathrm{keV}$ do ${ }^{153} \mathrm{Sm}$ no pico de $106,12 \mathrm{keV}$ do ${ }^{239} \mathrm{~Np}$ foi um dos problemas da análise por meio da irradiação térmica de longa duração.

As frações mássicas de U determinadas nas cascas de árvore, obtidas pela ENAA de longa duração, variaram de $87 \pm 6 \mathrm{ng} \mathrm{g}^{-1}$ a $502 \pm 4 \mathrm{ng} \mathrm{g}^{-1}$. A variação nas frações mássicas de $\mathrm{U}$ entre as amostras de cascas de árvores se deve, provavelmente, aos diferentes pontos de coleta destas amostras, ou seja, da localização das árvores que foram de locais com diferentes níveis de poluição. Além disso, foram coletadas cascas de diferentes espécies arbóreas que apresentam estruturas com porosidades distintas, o que afeta na retenção do material particulado.

A comparação entre as médias das frações mássicas de U obtidas nas cascas de árvores, por procedimentos distintos de análise, indicou que os resultados obtidos na INAA de longa duração apresentaram diferenças significativas em comparação aos obtidos por ENAA de curta e de longa duração. Disso podemos concluir que este procedimento produz resultados não reprodutíveis e não é indicado para a análise deste tipo de matriz. Em relação aos limites de detecção de U nas análises das cascas de árvores, foram obtidos valores menores com a ENAA de longa duração do que com a ENAA de curta duração.

No caso das análises das amostras de bromélias, o procedimento mais adequado foi a ENAA de longa duração devido à boa precisão dos resultados e aos baixos limites de detecção. Com a INAA de curta duração, não foi possível quantificar U em nenhuma das amostras devido às baixas frações mássicas deste elemento neste material.

Já com a ENAA de curta duração, o U pôde ser determinado em apenas três das cinco amostras analisadas e seus resultados foram precisos, com valores de HorRat menores que 2. Assim como observado nas cascas de árvores, os resultados das amostras de bromélias obtidos com INAA de longa duração apresentaram desvios padrões relativos, em geral, maiores que dos demais procedimentos estudados neste trabalho. Além disso, a INAA de longa duração apresentou problemas na detecção do pico de $277,60 \mathrm{keV}$ do ${ }^{239} \mathrm{~Np}$ devido aos baixos teores de U nessas amostras. 
Nas amostras de bromélias, as frações mássicas de U, obtidas pela ENAA de longa duração, variaram de $34 \pm 16 \mathrm{ng} \mathrm{g}^{-1}$ a $80 \pm 2 \mathrm{ng} \mathrm{g}^{-1}$. Essas variações ocorrem devido à diferença nos pontos de coleta ou de exposição dessas amostras em locais de diferentes níveis de poluição e por períodos distintos. Com relação à comparação entre as médias das frações mássicas obtidas nas amostras de bromélias por diferentes procedimentos de análise, foi verificado que os resultados da INAA de longa duração apresentaram diferenças significativas em comparação aos determinados por ENAA de curta e longa duração. Deste modo, podemos concluir, assim como para as cascas de árvores, que a INAA de longa duração produz resultados não reprodutíveis e não deve ser utilizada para análise deste tipo de amostra.

Os resultados obtidos permitiram concluir que o procedimento mais indicado para a determinação de U em amostras de biomonitores é a ENAA de longa duração. Com este procedimento foi possível realizar a quantificação de U em todas as amostras estudadas devido aos seus baixos limites de detecção e à redução do problema de interferência nas análises. Além disso, na ENAA de longa duração foram obtidos os menores valores de incerteza das frações mássicas determinadas, bem como os resultados apresentaram reprodutibilidade igual ou superior às obtidas com os outros procedimentos. 


\section{REFERÊNCIAS BIBLIOGRÁFICAS}

ACHARYA, R. N.; NAIR, A. G. C.; REDDY, A. V. R.; MANOHAR, S. B. Validation of a neutron activation analysis method using k0-standardization. Applied Radiation and Isotopes, v. 57, n. 3, p. 391-398, 2002.

ALSABBAGH, A.; ZAIDAN, L.; HARAHSHEH, I.; SUNBUL, N. B.; LANDSBERGER, S. Investigation of jordanian uranium resources in carbonate rocks. Journal of Radioanalytical and Nuclear Chemistry, v. 308, n. 3, p. 1063-1070, 2016.

AMATO-LOURENCO, L. F.; MOREIRA, T. C. L.; SOUZA, V. C. de O.; BARBOSA, F.; SAIKI, M.; SALDIVA, P. H. N.; MAUAD, T. The influence of atmospheric particles on the elemental content of vegetables in urban gardens of São Paulo, Brazil. Environmental Pollution, v. 216, p. 125 - 134, 2016.

AMIEL, S.; GILAT, J.; HEYMANN, D. Uranium content of chondrites by thermal neutron activation and delayed neutron counting. Geochimica et Cosmochimica Acta, v. 31, n. 9, p. 1499-1503, 1967.

ASIM, M.; WASIM, M.; MOHAMMAD, B. Development of methodologies for the analysis of uranium ores by k0-instrumental neutron activation analysis and inductively coupled plasma atomic emission spectrometry. Journal of Radioanalytical and Nuclear Chemistry, v. 311, n. 3, p. 1963-1969, 2017.

ATALLA, L.; LIMA, F. Determination of uranium in thorium matrixes by epithermal neutron activation analysis. Journal of Radioanalytical and Nuclear Chemistry, v. 20, n. 2, p. 607-618, 1974.

ATALLA, L. T. Estudo da determinação de urânio por análise por ativação com neutrons epitérmicos. Tese (Doutorado) — Instituto de Energia Atômica, São Paulo, 1973. Disponível em: <http://www.iaea.org/inis/collection/NCLCollectionStore/_Public/05/108/5108936.pdf>. Acesso em: 25 fev 2018.

ATSDR. Agency for Toxic Substances and Disease Registry. Toxicological profile for uranium. Georgia, 2011. Disponível em: <https://www.atsdr.cdc.gov/ToxProfiles/tp150.pdf>. Acesso em: 13 mar 2018.

BAIK, M. H.; KANG, M. J.; CHO, S. Y.; JEONG, J. A comparative study for the determination of uranium and uranium isotopes in granitic groundwater. Journal of Radioanalytical and Nuclear Chemistry, v. 304, n. 1, p. 9-14, 2015.

BALLA, M.; MOLNÁR, Z.; KŐRÖS, Á. Uncertainty budget and validation of NAA using Reference Materials. Journal of Radioanalytical and Nuclear Chemistry, v. 259, n. 3, p. 395-400, 2004.

BANNING, A.; BENFER, M. Drinking water uranium and potential health effects in the German federal state of Bavaria. International Journal of Environmental Research and Public Health, v. 14, n. 8, p. 927, 2017.

BÁRTOVÁ, H.; KUČERA, J.; MUSÍLEK, L.; TROJEK, T.; GREGOROVÁ, E. Determination of $\mathrm{U}$, Th and $\mathrm{K}$ in bricks by gamma-ray spectrometry, $\mathrm{X}$-ray fluorescence analysis and neutron activation analysis. Radiation Physics and Chemistry, 2017. 
BELLIS, D.; MA, R.; BRAMALL, N.; MCLEOD, C.; CHAPMAN, N.; SATAKE, K. Airborne uranium contamination - as revealed through elemental and isotopic analysis of tree bark. Environmental Pollution, v. 114, n. 3, p. 383 - 387, 2001.

BEM, H.; BOU-RABEE, F. Environmental and health consequences of depleted uranium use in the 1991 gulf war. Environment International, v. 30, n. 1, p. 123-134, 2004.

BODE, P. Instrumental and organizational aspects of a neutron activation analysis laboratory. Tese (Doutorado) - University of Technology, Delft, 1996. Disponível em: <https:// repository.tudelft.nl/islandora/object/uuid\%3A438b9110-fb94-4015-b277-1c5fba96ac71>. Acesso em: 21 mar 2018.

BORYŁO, A. Determination of uranium isotopes in environmental samples. Journal of Radioanalytical and Nuclear Chemistry, v. 295, n. 1, p. 621-631, 2013.

BOULYGA, S. F.; TESTA, C.; DESIDERI, D.; BECKER, J. S. Optimisation and application of ICP-MS and alpha-spectrometry for determination of isotopic ratios of depleted uranium and plutonium in samples collected in Kosovo. Journal of Analytical Atomic Spectrometry, v. 16, n. 11, p. 1283-1289, 2001.

BRUGGE, D.; BUCHNER, V. Health effects of uranium: new research findings. Reviews on Environmental Health, v. 26, n. 4, p. 231-249, 2011.

BRUGGE, D.; DELEMOS, J.; OLDMIXON, B. Exposure pathways and health effects associated with chemical and radiological toxicity of natural uranium: A review. Reviews on Environmental Health, v. 20, n. 3, p. 177-193, 2005.

BYERS, M.; LANDSBERGER, S.; SCHNEIDER, E.; EDER, S. Neutron activation analysis for the characterization of seawater uranium adsorbents. Applied Radiation and Isotopes, v. 133, p. $4-8,2018$.

CAMPOY-DIAZ, A. D.; ARRIBERE, M. A.; GUEVARA, S. R.; VEGA, I. A. Bioindication of mercury, arsenic and uranium in the apple snail pomacea canaliculata (caenogastropoda, ampullariidae): Bioconcentration and depuration in tissues and symbiotic corpuscles.

Chemosphere, v. 196, p. 196 - 205, 2018.

CATINON, M.; AYRAULT, S.; CLOCCHIATTI, R.; BOUDOUMA, O.; ASTA, J.; TISSUT, M.; RAVANEL, P. The anthropogenic atmospheric elements fraction: A new interpretation of elemental deposits on tree barks. Atmospheric Environment, v. 43, n. 5, p. 1124 - 1130, 2009.

CDW. Federal Provincial Territorial Committee on Drinking Water. Uranium in Drinking Water. Ottawa, 2017. Disponível em: <https://www.canada.ca/en/health-canada/programs/ consultation-uranium-drinking-water/document.html>. Acesso em: 13 mar 2018.

CETESB. Companhia ambiental do estado de São Paulo. Qualidade do ar no estado de São Paulo 2017. São Paulo, 2017. Disponível em: <https://cetesb.sp.gov.br/ar/wp-content/ uploads/sites/28/2018/05/relatorio-qualidade-ar-2017.pdf>. Acesso em: 01 nov 2018.

CNEA. National Atomic Energy Comission. Certificate of analysis: IAEA RLA 2/2014 Trace Elements in Volcanic Ashes. Áustria, 2016.

CURRIE, L. A. Detection and quantification limits: origins and historical overview. Analytica Chimica Acta, v. 391, n. 2, p. 127-134, 1999. 
DANESHVAR, G.; JABBARI, A.; YAMINI, Y.; PAKI, D. Determination of uranium and thorium in natural waters by ICP-OES after on-line solid phase extraction and preconcentration in the presence of 2,3-dihydro-9,10-dihydroxy-1,4-antracenedion. Journal of Analytical Chemistry, v. 64, n. 6, p. 602-608, 2009.

DYBCZYNSKI, R.; DANKO, B.; POLKOWSKAMOTRENKO, H.; SAMCZYNSKI, Z. RNAA in metrology: A highly accurate (definitive) method. Talanta, v. 71, n. 2, p. 529-536, 2007.

EBY, N. Instrumental Neutron Activation Analysis. 2018. Geochemical Instrumentation and Analysis. Disponível em: <https://serc.carleton.edu/research_education/geochemsheets/ techniques/INAA.html>. Acesso em: $20 \mathrm{fev} 2018$.

EI-TAHER, A.; NOSSAIR, A.; AZZARA, A. H.; KRATZ, K. L.; ABDEL-HALIM, A. S. Determination of traces of uranium and thorium concentration in some egyptian environmental matrices by instrumental neutron activation analysis. In: Proceedings of the Environmental Physics Conference. Egypt: [s.n.], 2004.

EL-TAHER, A.; KHATER, A. E. Elemental characterization of Hazm El-Jalamid phosphorite by instrumental neutron activation analysis. Applied Radiation and Isotopes, v. 114, p. 121-127, 2016.

ESSIEN, I. O.; SANDOVAL, D. N.; KURODA, P. K. Deposition of excess amount of natural U from the atmosphere. Health Physics, v. 48, n. 3, p. 325-331, 1985.

EURACHEM WORKING GROUP. The fitness for purpose of analytical methods: A laboratory guide to method validation and related topics. [S.1.], 1998. Disponível em: $<$ https://www.eurachem.org/images/stories/Guides/pdf/MV_guide_1998_EN.pdf>. Acesso em: 13 mar 2018.

EURACHEM WORKING GROUP. Eurachem/CITAC guide: Quantifying uncertainty in analytical measurement. 3. ed. [S.1.], 2012. Disponível em: <https://eurachem.org/images/ stories/Guides/pdf/QUAM2012_P1.pdf>. Acesso em: 01 abr 2018.

FIGUEIREDO, A. M. G.; NOGUEIRA, C. A.; SAIKI, M.; MILIAN, F. M.; DOMINGOS, M. Assessment of atmospheric metallic pollution in the metropolitan region of São Paulo, Brazil, employing Tillandsia usneoides 1. as biomonitor. Environmental Pollution, v. 145, n. 1, p. 279-292, 2007.

GERALDO, S. M.; CANTERAS, F. B.; MOREIRA, S. Biomonitoring of environmental pollution using growth tree rings of Tipuana tipu: Quantification by synchrotron radiation total reflection X-ray fluorescence. Radiation Physics and Chemistry, v. 95, p. 346-348, 2014.

GREENBERG, R.; LINDSTROM, R.; SIMONS, D. Instrumental neutron activation analysis for certification of ion-implanted arsenic in silicon. Journal of Radioanalytical and Nuclear Chemistry, v. 245, n. 1, p. 57-63, 2000.

GREENBERG, R. R.; BODE, P.; FERNANDES, E. A. D. N. Neutron activation analysis: A primary method of measurement. Spectrochimica Acta Part B, v. 66, n. 3-4, p. 193-241, 2011. 
GROGAN, K. P.; O'KELLY, D. J. Analytical applications of delayed and instrumental neutron activation analysis. Journal of Radioanalytical and Nuclear Chemistry, v. 299, n. 1, p. 543-549, 2014.

GRUBBS, F. E. Procedures for detecting outlying observations in samples. Technometrics, v. 11, n. 1, p. 1-21, 1969.

HAMIDATOU, L.; SLAMENE, H.; AKHAL, T.; ZOURANEN, B. Concepts, instrumentation and techniques of neutron activation analysis. In: KHARFI, F. (Ed.). Imaging and Radioanalytical Techniques in Interdisciplinary Research - Fundamentals and Cutting Edge Applications. Rijeka: [s.n.], 2013.

HAYNES, W. CRC handbook of chemistry and physics: a ready-reference book of chemical and physical data. Florida: [s.n.], 2014.

HEYDORN, K. Validation of neutron activation analysis techniques. In: Techniques and Instrumentation in Analytical Chemistry. [S.1.: s.n.], 1995. v. 17, p. 89-110.

HEYDORN, K. Menage a trois: Activation, analysis and uncertainty, 10 projections into the impending millenium. Journal of Radioanalytical and Nuclear Chemistry, v. 244, n. 1, p. 7-15, 2000.

HIMRI, M. E.; PASTOR, A.; GUARDIA, M. de la. Determination of uranium in tap water by ICP-MS. Fresenius' Journal of Analytical Chemistry, v. 367, n. 2, p. 151-156, 2000.

HORWITZ, W.; ALBERT, R. The horwitz ratio (HorRat): a useful index of method performance with respect to precision. Journal of AOAC International, v. 89, n. 4, p. 1095-1109, 2006.

IAEA. International Atomic Energy Agency. Certificate of analysis: IAEA-140/TM - Trace and Methylmercury in Seaweed (fucus sp.). Áustria, 2000.

IAEA. International Atomic Energy Agency. Certificate of analysis: IAEA-SOIL-7 - Trace Elements in Soil. Áustria, 2000.

IAEA. International Atomic Energy Agency. Thermal neutron capture cross sections resonance integrals and g-factors. [S.1.], 2003. Disponível em: <http: //www.iaea.org/inis/collection/NCLCollectionStore/_Public/34/020/34020739.pdf>. Acesso em: 05 mar 2018.

IAG. Instituto de Astronomia, Geofísica e Ciências Atmosféricas. Boletim climatológico anual da estação meteorológica do IAG/USP 2017. São Paulo, 2017. Disponível em: <http://www.estacao.iag.usp.br/Boletins/2017.pdf>. Acesso em: 01 nov 2018.

INCT. Institute of Nuclear Chemistry and Technology. Certificate of analysis: INCT - CTA VTL - 2 - Virgínia Tobacco Leaves. Poland, 1997.

INCT. Institute of Nuclear Chemistry and Technology. Certificate of analysis: CTA-VTL-2 Oriental Basma Tobacco. Poland, 2010.

INCT. Institute of Nuclear Chemistry and Technology. Certificate of analysis: INCT - M3 Herring Tissue. Poland, 2015. 
INMETRO. Instituto Nacional de Metrologia, Qualidade e Tecnologia. VIM - Vocabulário Internacional de Metrologia: Conceitos fundamentais e gerais e termos associados. Rio de Janeiro, 2012. Disponível em: <http://www.inmetro.gov.br/inovacao/publicacoes/vim_2012. pdf>. Acesso em: 13 mar 2018.

JCGM-INMETRO. Joint Committee for Guides in Metrology. GUM - Avaliação de dados de medição: Guia para a expressão de incerteza de medição. [S.1.], 2008. Disponível em: $<$ http://www.inmetro.gov.br/noticias/conteudo/iso_gum_versao_site.pdf >. Acesso em: 13 mar 2018.

JIA, G.; BELLI, M.; SANSONE, U.; ROSAMILIA, S.; OCONE, R.; GAUDINO, S. Determination of uranium isotopes in environmental samples by alpha-spectrometry. Journal of Radioanalytical and Nuclear Chemistry, v. 253, n. 3, p. 395-406, 2002.

KARANGELOS, D.; ANAGNOSTAKIS, M.; HINIS, E.; SIMOPOULOS, S.; ZUNIC, Z. Determination of depleted uranium in environmental samples by gamma-spectroscopic techniques. Journal of Environmental Radioactivity, v. 76, n. 3, p. 295 - 310, 2004.

KARUNAKARA, N.; SOMASHEKARAPPA, H.; NARAYANA, Y.; AVADHANI, D.; MAHESH, H.; SIDDAPPA, K. ${ }^{226} \mathrm{Ra},{ }^{40} \mathrm{~K}$ and ${ }^{7} \mathrm{Be}$ activity concentrations in plants in the environment of Kaiga, India. Journal of Environmental Radioactivity, v. 65, n. 3, p. 255 266, 2003.

KEITH, L. S.; FAROON, O. M.; FOWLER, B. A. CHAPTER 45 - Uranium. In: NORDBERG, G. F.; ; FOWLER, B. A.; ; NORDBERG, M.; ; FRIBERG, L. T. (Ed.). Handbook on the Toxicology of Metals. Third edition. Burlington: [s.n.], 2007. p. 881-903.

KUČERA, J.; BODE, P.; STVPÁNEK, V. The 1993 ISO guide to the expression of uncertainty in measurement applied to NAA. Journal of Radioanalytical and Nuclear Chemistry, v. 245, n. 1, p. 115-122, 2000.

KUČERA, J.; BODE, P.; STVPÁNEK, V. Quantifying Uncertainty in Nuclear Analytical Measurements. [S.1.]: International Atomic Energy Agency, 2004. (IAEA-TECDOC).

LANDSBERGER, S.; KAPSIMALIS, R. Comparison of neutron activation analysis techniques for the determination of uranium concentrations in geological and environmental materials. Journal of Environmental Radioactivity, v. 117, p. 41—44, 2013.

LANDSBERGER, S.; SHARP, A.; WANG, S.; PONTIKES, Y.; TKACZYK, A. Characterization of bauxite residue (red mud) for ${ }^{235} \mathrm{U},{ }^{238} \mathrm{U},{ }^{232} \mathrm{Th}$ and ${ }^{40} \mathrm{~K}$ using neutron activation analysis and the radiation dose levels as modeled by MCNP. Journal of Environmental Radioactivity, v. 173, p. 97 - 101, 2017.

LANDSBERGER, S.; TAMALIS, D.; LEBLANC, C.; YOHO, M. D. Disequilibrium in the uranium and actinium series in oil scale samples. Journal of Environmental Radioactivity, v. 166, p. 126-129, 2017.

LBNL. Lawrence Berkeley National Laboratory. Lund/LBNL Nuclear Data Search. Berkeley, 2018. Disponível em: <http://nucleardata.nuclear.lu.se/toi/>. Acesso em: 4 Nov 2018.

MAIDANA, N. L. Medida de seções de choque para reações de captura de nêutrons no ${ }^{57}$ Co, ${ }^{137}$ Cs $e^{241}$ Am considerando a formação de estados isoméricos. Tese (Doutorado) - 
Instituto de Pesquisas Energéticas e Nucleares, Universidade de São Paulo, São Paulo, Brasil, São Paulo, 2000. Disponível em: <http://pelicano.ipen.br/PosG30/TextoCompleto/Nora\% 20Lia\%20Maidana_D.pdf>. Acesso em: 05 mar 2018.

MÄRTEN, A.; BERGER, D.; KÖHLER, M.; MERTEN, D. The dendroanalysis of oak trees as a method of biomonitoring past and recent contamination in an area influenced by uranium mining. Environmental Science and Pollution Research, v. 22, n. 24, p. 19417-19425, 2015 .

MCDIARMID, M. A.; ENGELHARDT, S.; OLIVER, M.; GUCER, P.; WILSON, P. D.; KANE, R.; KABAT, M.; KAUP, B.; ANDERSON, L.; HOOVER, D.; BROWN, L.; HANDWERGER, B.; ALBERTINI, R. J.; JACOBSON-KRAM, D.; THORNE, C. D.; SQUIBB, K. S. Health effects of depleted uranium on exposed gulf war veterans: A 10-year follow-up. Journal of Toxicology and Environmental Health, Part A, v. 67, p. 277-296, 2004.

MILONE, G. Estatística: geral e aplicada. São Paulo: Thomson Learning, 2004.

MOREIRA, E. G.; VASCONCELLOS, M. B. A.; SAIKI, M. Measurement uncertainty assessment in the instrumental neutron activation analysis of chromium, manganese, molybdenum and nickel in steel. In: International Nuclear Atlantic Conference-INAC. [s.n.], 2005. Disponível em: <https://www.ipen.br/biblioteca/cd/inac/2005/full/Dica.pdf>. Acesso em: 13 mar 2018.

MOREIRA, E. G.; VASCONCELLOS, M. B. A.; SAIKI, M. Uncertainty assessment in instrumental neutron activation analysis of biological materials. Journal of Radioanalytical and Nuclear Chemistry, v. 269, n. 2, p. 377-382, 2006.

MOREIRA, T. C. L.; OLIVEIRA, R. C. de; AMATO, L. F. L.; KANG, C.-M.; SALDIVA, P. H. N.; SAIKI, M. Intra-urban biomonitoring: source apportionment using tree barks to identify air pollution sources. Environment International, v. 91, p. 271-275, 2016.

MORGAN, J. W.; LOVERING, J. F. The determination of uranium and thorium in rocks by neutron activation analysis. Analytica Chimica Acta, v. 28, p. 405-417, 1963.

NIST. National Institute of Standards and Technology. Certificate of analysis: NIST - 1575 Pine Needles. Estados Unidos, 1993.

NIST. National Institute of Standards and Technology. Certificate of analysis: NIST - 1633b - Constituent Elements in Coal fly Ash. Estados Unidos, 1993.

NIST. National Institute of Standards and Technology. Certificate of analysis: NIST - 1566b - Oyster Tissue. Estados Unidos, 2001.

NIST. National Institute of Standards and Technology. Certificate of analysis: NIST - 1632d - Trace Elements in Coal. Estados Unidos, 2011.

NRC. National Research Council. Appendix B: An uncertainty analysis of neutron activation measurements in Hiroshima and Nagasaki. In: Status of the Dosimetry for the Radiation Effects Research Foundation. Washington: The National Academies Press, 2001. p. 128-129. 
NUCLEAR POWER. Application of Neutrons. 2018. Disponível em: <https: //www.nuclear-power.net/nuclear-power/reactor-physics/atomic-nuclear-physics/ fundamental-particles/neutron/applications-neutrons/>. Acesso em: 20 fev 2018.

NUCLEAR POWER. Cross-sections of Uranium. 2018. Disponível em: <https://www. nuclear-power.net/nuclear-power-plant/nuclear-fuel/uranium/cross-sections-of-uranium/ \#prettyPhoto/0/>. Acesso em: $21 \mathrm{fev} 2018$.

NUCLEIDE - LARA. Library for Gamma and Alpha Emissions. 2018. Disponível em: <http://www.nucleide.org/Laraweb/index.php>. Acesso em: 06 mai 2018.

O’MEARA, J.; CHETTLE, D.; MCNEILL, F.; WEBBER, C. In vivo X-ray fluorescence (XRF) measurement of uranium in bone. Applied Radiation and Isotopes, v. 49, n. 5, p. 713 $-715,1998$.

OSTERC, A.; STIBILJ, V. Measurement uncertainty of iodine determination in radiochemical neutron activation analysis. Accreditation and Quality Assurance, v. 10, n. 5, p. 235-240, 2005.

PAPASTEFANOU, C. Depleted uranium in military conflicts and the impact on the environment. Health Physics, v. 83, n. 2, p. 280-282, 2002.

PARRISH, R. R.; HORSTWOOD, M.; ARNASON, J. G.; CHENERY, S.; BREWER, T.; LLOYD, N. S.; CARPENTER, D. O. Depleted uranium contamination by inhalation exposure and its detection after 20 years: Implications for human health assessment. Science of the Total Environment, v. 390, n. 1, p. 58 - 68, 2008.

PERRY, J. H. Chemical engineers' handbook. 2. ed. [S.1.]: McGraw-Hill, 1941.

PULHANI, V.; KAYASTH, S.; MORE, A. K.; MISHRA, U. C. Determination of traces of uranium and thorium in environmental matrices by neutron activation analysis. Journal of Radioanalytical and Nuclear Chemistry, v. 243, n. 3, p. 625-629, 2000.

RAJU, K. K.; RAJU, A. N. Biogeochemical investigation in south eastern andhra pradesh: the distribution of rare earths, thorium and uranium in plants and soils. Environmental Geology, v. 39, n. 10, p. 1102-1106, 2000.

RODRÍGUEZ, R.; AVIVAR, J.; FERRER, L.; LEAL, L. O.; CERDÀ, V. Uranium monitoring tool for rapid analysis of environmental samples based on automated liquid-liquid microextraction. Talanta, v. 134, p. 674-680, 2015.

ROSAMILIA, S.; GAUDINO, S.; SANSONE, U.; BELLI, M.; JERAN, Z.; RUISI, S.; ZUCCONI, L. Uranium isotopes, metals and other elements in lichens and tree barks collected in bosnia-herzegovina. Journal of Atmospheric Chemistry, v. 49, n. 1, p. 447-460, 2004.

SAHOO, S. K.; ENOMOTO, H.; TOKONAMI, S.; ISHIKAWA, T.; UJIĆ, P.; ČELIKOVIĆ, I.; ŽUNIĆ, Z. S. Determination of depleted uranium in environmental bio-monitor samples and soil from target sites in western balkan region. In: AIP. AIP Conference Proceedings. [S.1.], 2008. v. 1034, n. 1, p. 287-290.

SANTOS, J. S.; TEIXEIRA, L. S.; SANTOS, W. N.; LEMOS, V. A.; GODOY, J. M.; FERREIRA, S. L. Uranium determination using atomic spectrometric techniques: An overview. Analytica Chimica Acta, v. 674, n. 2, p. 143 - 156, 2010. 
SAWICKI, M.; LECERCLé, D.; GRILLON, G.; GALL, B. L.; SéRANDOUR, A.-L.; PONCY, J.-L.; BAILLY, T.; BURGADA, R.; LECOUVEY, M.; CHALLEIX, V.; LEYDIER, A.; PELLET-ROSTAING, S.; ANSOBORLO, E.; TARAN, F. Bisphosphonate sequestering agents. synthesis and preliminary evaluation for in vitro and in vivo uranium(vi) chelation. European Journal of Medicinal Chemistry, v. 43, n. 12, p. 2768 - 2777, 2008.

SEF. Superintendência do Espaço Físico da USP. O Espaço Físico na USP. São Paulo, 2014. Disponível em: <http://www.sef.usp.br/wp-content/uploads/sites/52/2017/11/Espaco-Fisico. pdf>. Acesso em: 01 nov 2018.

SHTANGEEVA, I. Uptake of uranium and thorium by native and cultivated plants. Journal of Environmental Radioactivity, v. 101, n. 6, p. 458 - 463, 2010.

SINGER, D. M.; ZACHARA, J. M.; JR, G. E. B. Uranium speciation as a function of depth in contaminated hanford sediments - a micro-XRF, micro-XRD, and micro- and bulk-XAFS study. Environmental Science and Technology, v. 43, n. 3, p. 630-636, 2009.

SINGH, S.; MALHOTRA, R.; KUMAR, J.; SINGH, B.; SINGH, L. Uranium analysis of geological samples, water and plants from Kulu Area, Himachal Pradesh, India. In:

Proceedings of the 20th International Conference on Nuclear Tracks in Solids. [S.1.: s.n.], 2001. v. 34, n. 1 , p. $427-431$.

SRNCIK, M.; STEIER, P.; WALLNER, G. Depth profile of ${ }^{236} \mathrm{U} /{ }^{238} \mathrm{U}$ in soil samples in La Palma, Canary Islands. Journal of Environmental Radioactivity, v. 102, n. 6, p. 614 - 619, 2011.

TUKEY, J. W. Comparing individual means in the analysis of variance. Biometrics, v. 5, n. 2, p. 99-114, 1949.

VASCONCELlOS, M. B. A.; SAIKI, M.; FÁVARO, D. I. T.; MAIHARA, V. A.; FIGUEIREDO, A. M. G.; CATHARINO, M. G. M. Neutron activation analysis at the research reactor center of IPEN/CNEN-SP - Biological and environmental applications. Journal of Radioanalytical and Nuclear Chemistry, v. 259, n. 3, p. 489-492, 2004.

WEAVER, J. N. Rapid, instrumental neutron activation analysis for the determination of uranium in environmental matrices. Analytical Chemistry, v. 46, n. 9, p. 1292-1294, 1974.

WITKOWSKA, E.; SZCZEPANIAK, K.; BIZIUK, M. Some applications of neutron activation analysis. Journal of Radioanalytical and Nuclear Chemistry, v. 265, n. 1, p. 141-150, 2005.

WOOD, R. How to validate analytical methods. TrAC Trends in Analytical Chemistry, v. 18, n. 9-10, p. 624-632, 1999.

ZHOU, H.; LIN, H.; LIU, G.; LI, J.; LIANG, Q.; ZHAO, Y. A neutron multiplicity analysis method for uranium samples with liquid scintillators. Nuclear Instruments and Methods in Physics Research Section A: Accelerators, Spectrometers, Detectors and Associated Equipment, v. 797, p. 70 - 76, 2015.

ZIKOVSKY, L. Determination of uranium in food in Quebec by neutron activation analysis. Journal of Radioanalytical and Nuclear Chemistry, v. 267, n. 3, p. 695-697, 2006. 


\section{APÊNDICE A - TABELAS DE RESULTADOS INDIVIDUAIS DAS FRAÇÕES MÁSSICAS DE U EM MATERIAIS DE REFERÊNCIA CERTIFICADOS}

TABELA A.1 - Resultados individuais das frações mássicas de $\mathrm{U}\left(\mathrm{ng} \mathrm{g}^{-1}\right)$ em materiais de referência certificados obtidas por INAA de curta duração.

\begin{tabular}{|c|c|c|}
\hline MRC & $\mathbf{n}$ & $\mathbf{F} \pm \mathbf{I}_{C}$ \\
\hline $\begin{array}{l}\text { IAEA - 140/TM } \\
\text { Seaweed }\end{array}$ & - & - \\
\hline $\begin{array}{l}\text { NIST - } 1575 \\
\text { Pine Needles }\end{array}$ & - & - \\
\hline $\begin{array}{c}\text { NIST - 1632d } \\
\text { Trace Elements in Coal }\end{array}$ & - & - \\
\hline $\begin{array}{l}\text { NIST - 1633b } \\
\text { Coal Fly Ash }\end{array}$ & 4 & $\begin{array}{c}8983 \pm 2285 ; 6783 \pm 2291 \\
5726 \pm 2132 ; 8983 \pm 771\end{array}$ \\
\hline $\begin{array}{c}\text { INCT - M3 } \\
\text { Herring Tissue }\end{array}$ & - & - \\
\hline $\begin{array}{c}\text { IAEA - SOIL - } 7 \\
\text { Trace Elements in Soil }\end{array}$ & - & - \\
\hline $\begin{array}{l}\text { NIST }-1566 \mathrm{~b} \\
\text { Oyster Tissue }\end{array}$ & - & - \\
\hline $\begin{array}{c}\text { INCT-CTA-VTL-2 } \\
\text { Virginia Tobacco Leaves }\end{array}$ & - & - \\
\hline $\begin{array}{c}\text { INCT - OBTL - } 5 \\
\text { Oriental Basma Tobacco Leaves }\end{array}$ & - & - \\
\hline IPEN - Mexilhão & - & - \\
\hline $\begin{array}{l}\text { IAEA - RLA 2/014 } \\
\text { Volcanic Ashes }\end{array}$ & 2 & $8212 \pm 1912 ; 7691 \pm 1898$ \\
\hline
\end{tabular}


TABELA A. 2 - Resultados individuais das frações mássicas de $\mathrm{U}\left(\mathrm{ng} \mathrm{g}^{-1}\right)$ em materiais de referência certificados obtidas por ENAA de curta duração.

\begin{tabular}{|c|c|c|}
\hline MRC & $\mathbf{n}$ & $\mathbf{F} \pm \mathbf{I}_{c}$ \\
\hline $\begin{array}{c}\text { IAEA - 140/TM } \\
\text { Seaweed }\end{array}$ & 8 & $\begin{array}{c}441 \pm 114 ; 671 \pm 146 \\
693 \pm 158 ; 1024 \pm 197 \\
506 \pm 136 ; 712 \pm 140 \\
842 \pm 191 ; 871 \pm 164\end{array}$ \\
\hline $\begin{array}{l}\text { NIST - } 1575 \\
\text { Pine Needles }\end{array}$ & - & - \\
\hline $\begin{array}{l}\text { NIST - 1632d } \\
\text { Trace Elements in Coal }\end{array}$ & 6 & $\begin{array}{c}494 \pm 90 ; 509 \pm 62 \\
552 \pm 56 ; 648 \pm 71 \\
536 \pm 68 ; 463 \pm 62\end{array}$ \\
\hline $\begin{array}{l}\text { NIST - } 1633 b \\
\text { Coal Fly Ash }\end{array}$ & 7 & $\begin{array}{c}8432 \pm 671 ; 9589 \pm 277 \\
8731 \pm 268 ; 8415 \pm 260 \\
9572 \pm 280 ; 7995 \pm 224 \\
9122 \pm 284\end{array}$ \\
\hline $\begin{array}{c}\text { INCT - M3 } \\
\text { Herring Tissue }\end{array}$ & - & - \\
\hline $\begin{array}{c}\text { IAEA - SOIL - } 7 \\
\text { Trace Elements in Soil }\end{array}$ & 4 & $\begin{array}{c}2553 \pm 309 ; 2774 \pm 227 \\
2402 \pm 244 ; 2612 \pm 340\end{array}$ \\
\hline $\begin{array}{l}\text { NIST - 1566b } \\
\text { Oyster Tissue }\end{array}$ & 4 & $\begin{array}{l}254 \pm 39 ; 249 \pm 44 \\
288 \pm 40 ; 238 \pm 42\end{array}$ \\
\hline $\begin{array}{c}\text { INCT-CTA-VTL-2 } \\
\text { Virginia Tobacco } \\
\text { Leaves }\end{array}$ & 3 & $\begin{array}{c}135 \pm 37 ; 177 \pm 44 \\
123 \pm 38\end{array}$ \\
\hline $\begin{array}{c}\text { INCT - OBTL - } 5 \\
\text { Oriental Basma Tobacco } \\
\text { Leaves }\end{array}$ & - & - \\
\hline IPEN - Mexilhão & - & - \\
\hline $\begin{array}{l}\text { IAEA - RLA 2/014 } \\
\text { Volcanic Ashes }\end{array}$ & 6 & $\begin{array}{l}6428 \pm 160 ; 9355 \pm 534 \\
7942 \pm 471 ; 8287 \pm 231 \\
8331 \pm 253 ; 8882 \pm 243\end{array}$ \\
\hline
\end{tabular}


TABELA A.3 - Resultados individuais das frações mássicas de $\mathrm{U}\left(\mathrm{ng} \mathrm{g}^{-1}\right)$ em materiais de referência certificados obtidas por INAA de longa duração.

\begin{tabular}{|c|c|c|c|c|}
\hline & & Energia dos & $t_{d}=7 \mathrm{~d}$ & $t_{d}=9 \mathrm{~d}$ \\
\hline MRC & $\mathbf{n}$ & $\begin{array}{c}\text { raios gama } \\
(\mathrm{keV})\end{array}$ & $\mathbf{F} \pm \mathbf{I}_{c}$ & $\mathbf{F} \pm \mathbf{I}_{c}$ \\
\hline \multirow[t]{2}{*}{ IAEA - 140/TM } & \multirow{2}{*}{4} & 106,12 & - & - \\
\hline & & 277,60 & $669 \pm 85 ; 633 \pm 68$ & $\begin{array}{l}430 \pm 31 ; 565 \pm 32 \\
620 \pm 62 ; 521 \pm 45\end{array}$ \\
\hline NIST - 1575 & & 106,12 & - & - \\
\hline Pine Needles & & 277,60 & - & - \\
\hline NIST - 1632d & & 106,12 & - & - \\
\hline $\begin{array}{l}\text { Trace Elements } \\
\quad \text { in Coal }\end{array}$ & 4 & 277,60 & $\begin{array}{c}416 \pm 18 ; 408 \pm 14 \\
512 \pm 31 ; 432 \pm 35\end{array}$ & $\begin{array}{l}476 \pm 21 ; 392 \pm 13 \\
401 \pm 17 ; 325 \pm 17\end{array}$ \\
\hline \multicolumn{5}{|l|}{ NIST - 1633b } \\
\hline & 4 & 106,12 & - & - \\
\hline \multirow[t]{2}{*}{ Coal Fly Ash } & & & & \\
\hline & & 277,60 & $\begin{array}{c}8406 \pm 67 ; 8244 \pm 149 \\
9575 \pm 85 ; 9286 \pm 78\end{array}$ & $\begin{array}{c}7823 \pm 91 ; 9923 \pm 124 \\
8980 \pm 94\end{array}$ \\
\hline INCT - M3 & & 106,12 & - & - \\
\hline Herring Tissue & & 277,60 & - & - \\
\hline IAEA - SOIL - 7 & & 106,12 & - & - \\
\hline $\begin{array}{l}\text { Trace Elements } \\
\quad \text { in Soil }\end{array}$ & 4 & 277,60 & $\begin{array}{l}1954 \pm 84 ; 2043 \pm 53 \\
2258 \pm 74 ; 2771 \pm 82\end{array}$ & $\begin{array}{l}2317 \pm 33 ; 1904 \pm 28 \\
2112 \pm 27 ; 2138 \pm 45\end{array}$ \\
\hline \multirow[t]{2}{*}{ Oyster Tissue } & 3 & 106,12 & $\begin{array}{c}258 \pm 25 ; 304 \pm 15 \\
313 \pm 14\end{array}$ & $\begin{array}{c}366 \pm 18 ; 295 \pm 10 \\
281 \pm 9\end{array}$ \\
\hline & & 277,60 & - & - \\
\hline
\end{tabular}


TABELA A.3 - Resultados individuais das frações mássicas de $\mathrm{U}$ (ng $\mathrm{g}^{-1}$ ) em materiais de referência certificados obtidas por INAA de longa duração (continuação).

\begin{tabular}{|c|c|c|c|c|}
\hline \multirow[b]{2}{*}{ MRC } & \multirow[b]{2}{*}{$\mathbf{n}$} & \multirow{2}{*}{$\begin{array}{l}\text { Energia dos } \\
\text { raios gama } \\
\quad(\mathrm{keV})\end{array}$} & \multirow{2}{*}{$\frac{t_{d}=7 \mathrm{~d}}{\mathbf{F} \pm \mathbf{I}_{c}}$} & \multirow{2}{*}{$\begin{array}{l}t_{d}=9 \mathrm{~d} \\
\mathbf{F} \pm \mathbf{I}_{c}\end{array}$} \\
\hline & & & & \\
\hline INCT-CTA-VTL-2 & \multirow{2}{*}{4} & 106,12 & $\begin{array}{c}139 \pm 6 ; 156 \pm 9 \\
184 \pm 6\end{array}$ & $\begin{array}{c}124 \pm 12 ; 158 \pm 9 \\
179 \pm 9\end{array}$ \\
\hline Virginia Tobacco & & 277,60 & $\begin{array}{c}105 \pm 12 ; 151 \pm 6 \\
149 \pm 10\end{array}$ & $\begin{array}{l}134 \pm 7 ; 182 \pm 21 \\
151 \pm 12 ; 188 \pm 13\end{array}$ \\
\hline \multicolumn{5}{|l|}{ Leaves } \\
\hline $\begin{array}{l}\text { INCT - OBTL - } 5 \\
\text { Oriental Basma }\end{array}$ & \multirow[t]{2}{*}{4} & 106,12 & $\begin{array}{c}96 \pm 18 ; 119 \pm 13 ; \\
142 \pm 5\end{array}$ & $\begin{array}{c}143 \pm 7 ; 137 \pm 10 \\
109 \pm 8 ; 124 \pm 8\end{array}$ \\
\hline Tobacco Leaves & & 277,60 & - & - \\
\hline \multirow[t]{2}{*}{ IPEN - Mexilhão } & & 106,12 & - & - \\
\hline & & 277,60 & - & - \\
\hline IAEA - RLA 2/014 & \multirow{2}{*}{4} & 106,12 & - & - \\
\hline Volcanic Ashes & & 277,60 & $\begin{array}{c}7909 \pm 71 ; 6338 \pm 72 \\
7533 \pm 127 ; 7431 \pm 37\end{array}$ & $\begin{array}{l}7987 \pm 40 ; 8658 \pm 72 \\
7953 \pm 69 ; 7712 \pm 41\end{array}$ \\
\hline
\end{tabular}


TABELA A.4 - Resultados individuais das frações mássicas de $\mathrm{U}\left(\mathrm{ng} \mathrm{g}^{-1}\right)$ em materiais de referência certificados obtidas por ENAA de longa duração.

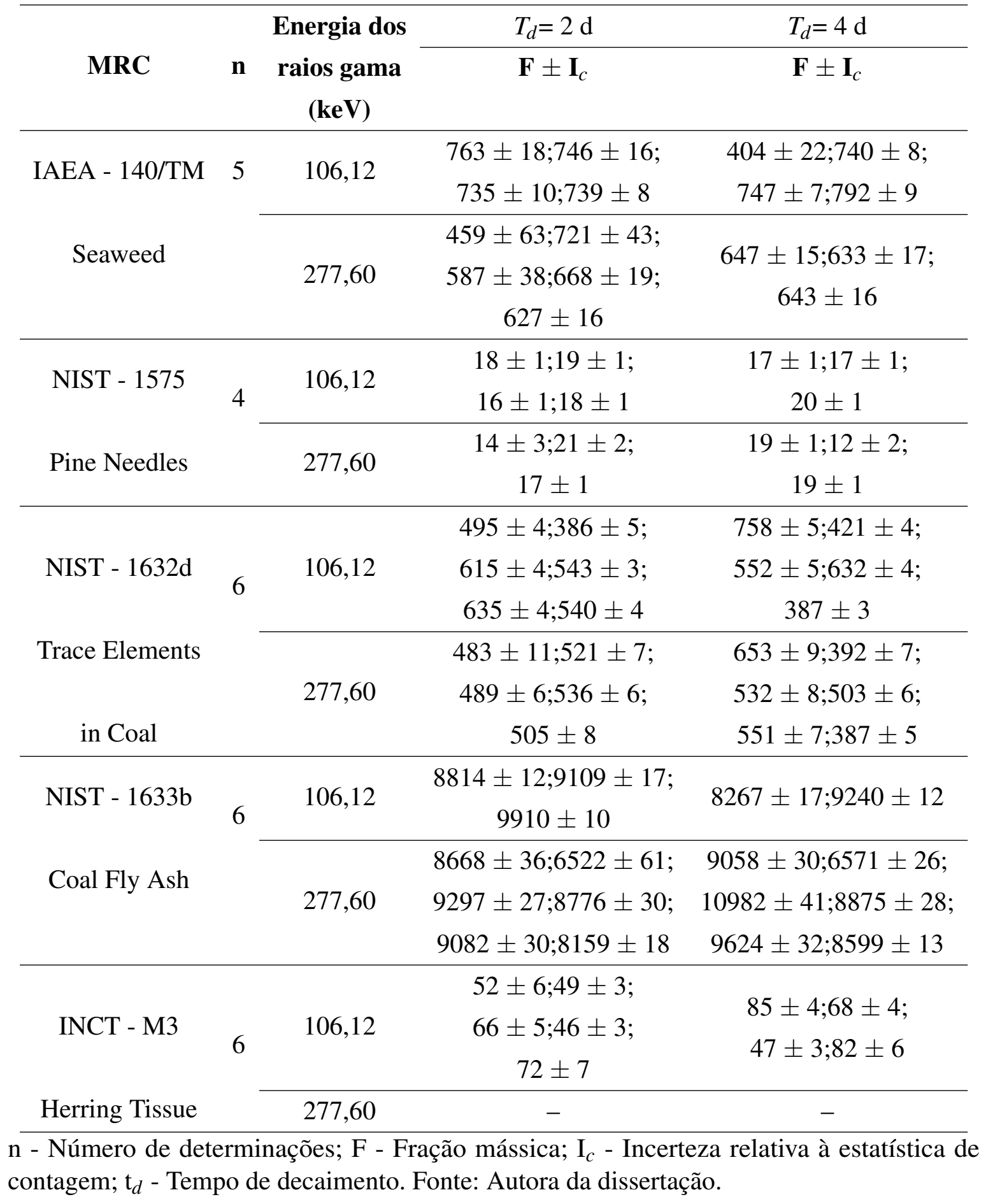


TABELA A.4 - Resultados individuais das frações mássicas de $\mathrm{U}\left(\mathrm{ng} \mathrm{g}^{-1}\right)$ em materiais de referência certificados obtidas por ENAA de longa duração (continuação).

\begin{tabular}{|c|c|c|c|c|}
\hline \multirow[b]{2}{*}{ MRC } & \multirow[b]{2}{*}{$\mathbf{n}$} & \multirow{2}{*}{$\begin{array}{l}\text { Energia dos } \\
\text { raios gama } \\
\quad(\mathrm{keV})\end{array}$} & \multirow{2}{*}{$\begin{array}{l}T_{d}=2 \mathrm{~d} \\
\mathbf{F} \pm \mathbf{I}_{c}\end{array}$} & \multirow{2}{*}{$\begin{array}{l}T_{d}=4 \mathrm{~d} \\
\mathbf{F} \pm \mathbf{I}_{c}\end{array}$} \\
\hline & & & & \\
\hline IAEA - SOIL - 7 & \multirow{2}{*}{4} & 106,12 & $\begin{array}{c}2170 \pm 6 ; 2855 \pm 11 \\
2074 \pm 7 ; 1266 \pm 5\end{array}$ & $\begin{array}{c}2760 \pm 8 ; 2584 \pm 11 \\
1824 \pm 8 ; 2865 \pm 12\end{array}$ \\
\hline Trace Elements & & 277,60 & $\begin{array}{l}2454 \pm 13 ; 2607 \pm 30 \\
2423 \pm 22 ; 2525 \pm 16\end{array}$ & $\begin{array}{r}2505 \pm 15 ; 2432 \pm 27 \\
2437 \pm 24 ; 2601 \pm 31\end{array}$ \\
\hline \multicolumn{5}{|l|}{ in Soil } \\
\hline NIST - 1566b & \multirow[t]{2}{*}{3} & 106,12 & $\begin{array}{c}295 \pm 4 ; 273 \pm 4 \\
529 \pm 9\end{array}$ & $\begin{array}{c}288 \pm 4 ; 300 \pm 5 \\
285 \pm 6\end{array}$ \\
\hline Oyster Tissue & & 277,60 & $227 \pm 8 ; 233 \pm 8$ & $\begin{array}{c}288 \pm 8 ; 312 \pm 10 \\
228 \pm 11\end{array}$ \\
\hline INCT-CTA-VTL-2 & \multirow{2}{*}{3} & 106,12 & $\begin{array}{c}180 \pm 4 ; 185 \pm 4 \\
165 \pm 4\end{array}$ & $\begin{array}{c}159 \pm 3 ; 185 \pm 3 \\
160 \pm 4\end{array}$ \\
\hline Virginia Tobacco & & 277,60 & $\begin{array}{c}176 \pm 7 ; 168 \pm 7 \\
160 \pm 7\end{array}$ & $\begin{array}{c}162 \pm 6 ; 188 \pm 5 \\
162 \pm 7\end{array}$ \\
\hline \multicolumn{5}{|l|}{ Leaves } \\
\hline INCT - OBTL - 5 & \multirow{2}{*}{3} & 106,12 & $\begin{array}{c}122 \pm 5 ; 115 \pm 4 \\
117 \pm 5\end{array}$ & $\begin{array}{c}124 \pm 8 ; 106 \pm 5 \\
134 \pm 3\end{array}$ \\
\hline Oriental Basma & & 277,60 & $\begin{array}{c}119 \pm 10 ; 119 \pm 9 ; \\
124 \pm 11\end{array}$ & $\begin{array}{c}83 \pm 15 ; 119 \pm 11 \\
122 \pm 7\end{array}$ \\
\hline \multicolumn{5}{|l|}{ Tobacco Leaves } \\
\hline \multirow[t]{2}{*}{ IPEN - Mexilhão } & \multirow[t]{2}{*}{3} & 106,12 & $\begin{array}{c}98 \pm 5 ; 68 \pm 4 \\
133 \pm 6\end{array}$ & $\begin{array}{c}88 \pm 5 ; 108 \pm 5 \\
87 \pm 5\end{array}$ \\
\hline & & 277,60 & $\begin{array}{c}50 \pm 10 ; 83 \pm 9 \\
139 \pm 14\end{array}$ & $\begin{array}{c}64 \pm 11 ; 60 \pm 10 \\
63 \pm 11\end{array}$ \\
\hline \multirow[t]{2}{*}{$\begin{array}{c}\text { IAEA - RLA 2/014 } \\
\text { Volcanic Ashes }\end{array}$} & \multirow[t]{2}{*}{3} & 106,12 & $\begin{array}{c}8276 \pm 16 ; 8737 \pm 13 \\
7771 \pm 17\end{array}$ & $8273 \pm 20 ; 7856 \pm 16$ \\
\hline & & 277,60 & $\begin{array}{l}8577 \pm 39 ; 7839 \pm 29 \\
8259 \pm 38 ; 8231 \pm 27\end{array}$ & $\begin{array}{l}8757 \pm 42 ; 7993 \pm 27 \\
8237 \pm 28 ; 8437 \pm 35\end{array}$ \\
\hline
\end{tabular}

n - Número de determinações; F - Fração mássica; $\mathrm{I}_{c}$ - Incerteza relativa à estatística de contagem; $\mathrm{t}_{d}$ - Tempo de decaimento. Fonte: Autora da dissertação. 


\section{APÊNDICE B - TABELAS DE RESULTADOS INDIVIDUAIS DAS FRAÇÕES MÁSSICAS DE U EM AMOSTRAS DE CASCAS DE ÁRVORES}

TABELA B.1 - Resultados individuais das frações mássicas de $\mathrm{U}\left(\mathrm{ng} \mathrm{g}^{-1}\right)$ em cascas de árvores obtidas por INAA e ENAA de curta duração.

\begin{tabular}{|c|c|c|c|}
\hline $\begin{array}{l}\text { Cascas de } \\
\text { árvores }\end{array}$ & $\mathbf{n}$ & Procedimento & $\mathbf{F} \pm \mathbf{I}_{c}$ \\
\hline \multirow{2}{*}{1} & \multirow[t]{2}{*}{2} & ENAA & $99 \pm 17 ; 99 \pm 17$ \\
\hline & & INAA & - \\
\hline \multirow[t]{2}{*}{2} & \multirow[t]{2}{*}{4} & ENAA & $\begin{array}{l}82 \pm 19 ; 72 \pm 16 \\
89 \pm 22 ; 90 \pm 22 *\end{array}$ \\
\hline & & INAA & - \\
\hline \multirow[t]{2}{*}{3} & \multirow[t]{2}{*}{3} & ENAA & $\begin{array}{c}135 \pm 20 ; 132 \pm 21 \\
131 \pm 20^{*}\end{array}$ \\
\hline & & INAA & - \\
\hline \multirow[t]{2}{*}{4} & \multirow[t]{2}{*}{4} & ENAA & $\begin{array}{l}103 \pm 19 ; 146 \pm 19 \\
141 \pm 23 ; 121 \pm 22\end{array}$ \\
\hline & & INAA & - \\
\hline \multirow[t]{2}{*}{5} & \multirow[t]{2}{*}{3} & ENAA & $\begin{array}{c}177 \pm 24 ; 191 \pm 22 \\
160 \pm 21\end{array}$ \\
\hline & & INAA & - \\
\hline \multirow[t]{2}{*}{6} & \multirow[t]{2}{*}{4} & ENAA & $\begin{array}{l}585 \pm 43 ; 628 \pm 49 \\
549 \pm 30 ; 588 \pm 45\end{array}$ \\
\hline & & INAA & - \\
\hline \multirow[t]{2}{*}{7} & \multirow[t]{2}{*}{4} & ENAA & $\begin{array}{l}211 \pm 25 ; 204 \pm 24 \\
208 \pm 29 ; 201 \pm 27\end{array}$ \\
\hline & & INAA & - \\
\hline \multirow[t]{2}{*}{8} & \multirow[t]{2}{*}{4} & ENAA & $\begin{array}{l}627 \pm 35 ; 550 \pm 36 \\
650 \pm 62 ; 504 \pm 67\end{array}$ \\
\hline & & INAA & - \\
\hline
\end{tabular}

n - Número de determinações; F - Fração mássica; $\mathrm{I}_{c}$ - Incerteza relativa à estatística de contagem; * - Resultados obtidos na segunda contagem. Fonte: Autora da dissertação. 
TABELA B.2 - Resultados individuais das frações mássicas de U (ng g ${ }^{-1}$ ) em cascas de árvores obtidas por INAA de longa duração.

\begin{tabular}{|c|c|c|c|}
\hline $\begin{array}{c}\text { Cascas de } \\
\text { árvores }\end{array}$ & $\mathbf{n}$ & $\begin{array}{c}\text { Energia dos } \\
\text { raios gama }(\mathrm{keV})\end{array}$ & $\mathbf{F} \pm \mathbf{I}_{c}(\mathbf{n})$ \\
\hline \multirow{2}{*}{1} & \multirow{2}{*}{3} & 106,12 & - \\
\hline & & 277,60 & $\begin{array}{c}164 \pm 7 ; 242 \pm 5 \\
96 \pm 5\end{array}$ \\
\hline \multirow{2}{*}{2} & \multirow{2}{*}{3} & 106,12 & - \\
\hline & & 277,60 & $\begin{array}{c}101 \pm 5 ; 69 \pm 3 \\
72 \pm 12\end{array}$ \\
\hline \multirow{2}{*}{3} & \multirow{2}{*}{3} & 106,12 & - \\
\hline & & 277,60 & $\begin{array}{c}104 \pm 9 ; 119 \pm 4 \\
108 \pm 8\end{array}$ \\
\hline \multirow{2}{*}{4} & \multirow{2}{*}{3} & 106,12 & - \\
\hline & & 277,60 & $\begin{array}{c}111 \pm 4 ; 99 \pm 4 \\
155 \pm 10\end{array}$ \\
\hline \multirow{2}{*}{5} & \multirow{2}{*}{3} & 106,12 & - \\
\hline & & 277,60 & $\begin{array}{c}103 \pm 7 ; 121 \pm 6 \\
223 \pm 12\end{array}$ \\
\hline \multirow{2}{*}{6} & \multirow{2}{*}{3} & 106,12 & - \\
\hline & & 277,60 & $\begin{array}{c}518 \pm 8 ; 527 \pm 15 \\
460 \pm 17\end{array}$ \\
\hline \multirow{2}{*}{7} & \multirow{2}{*}{3} & 106,12 & - \\
\hline & & 277,60 & $\begin{array}{c}110 \pm 9 ; 190 \pm 6 \\
170 \pm 8\end{array}$ \\
\hline \multirow{2}{*}{8} & \multirow{2}{*}{3} & 106,12 & - \\
\hline & & 277,60 & $\begin{array}{c}424 \pm 12 ; 457 \pm 10 \\
483 \pm 7\end{array}$ \\
\hline
\end{tabular}

n - Número de determinações; F - Fração mássica; $\mathrm{I}_{c}$ - Incerteza relativa à estatística de contagem. Fonte: Autora da dissertação. 
TABELA B.3 - Resultados individuais das frações mássicas de $\mathrm{U}\left(\mathrm{ng} \mathrm{g}^{-1}\right)$ em cascas de árvores obtidas por ENAA de longa duração.

\begin{tabular}{|c|c|c|c|c|}
\hline \multirow{2}{*}{$\begin{array}{c}\text { Cascas de } \\
\text { árvores }\end{array}$} & \multirow{2}{*}{$\mathbf{n}$} & \multirow{2}{*}{ Energia dos raios gama (keV) } & $T_{d}=2 \mathrm{~d}$ & $T_{d}=4 \mathrm{~d}$ \\
\hline & & & $\mathbf{F} \pm \mathbf{I}_{c}$ & $\mathbf{F} \pm \mathbf{I}_{c}$ \\
\hline \multirow[t]{2}{*}{1} & \multirow[t]{2}{*}{4} & 106,12 & $\begin{array}{l}95 \pm 2 ; 83 \pm 2 \\
96 \pm 1 ; 102 \pm 2\end{array}$ & $\begin{array}{l}93 \pm 1 ; 84 \pm 2 \\
91 \pm 1 ; 108 \pm 3\end{array}$ \\
\hline & & 277,60 & $\begin{array}{l}89 \pm 4 ; 86 \pm 4 \\
96 \pm 3 ; 121 \pm 5\end{array}$ & $\begin{array}{l}88 \pm 3 ; 82 \pm 5 \\
86 \pm 3 ; 91 \pm 5\end{array}$ \\
\hline \multirow[t]{2}{*}{2} & \multirow[t]{2}{*}{4} & 106,12 & $\begin{array}{l}85 \pm 1 ; 92 \pm 2 \\
97 \pm 2 ; 97 \pm 1\end{array}$ & $\begin{array}{l}91 \pm 2 ; 84 \pm 3 \\
102 \pm 3 ; 95 \pm 1\end{array}$ \\
\hline & & 277,60 & $\begin{array}{l}84 \pm 2 ; 86 \pm 4 \\
97 \pm 5 ; 93 \pm 3\end{array}$ & $\begin{array}{c}83 \pm 3 ; 111 \pm 5 \\
93 \pm 5 ; 93 \pm 3\end{array}$ \\
\hline \multirow[t]{2}{*}{3} & \multirow[t]{2}{*}{4} & 106,12 & $\begin{array}{l}132 \pm 2 ; 129 \pm 2 \\
147 \pm 1 ; 177 \pm 2\end{array}$ & $\begin{array}{l}132 \pm 2 ; 131 \pm 2 \\
147 \pm 1 ; 178 \pm 2\end{array}$ \\
\hline & & 277,60 & $\begin{array}{l}139 \pm 5 ; 127 \pm 5 \\
138 \pm 3 ; 175 \pm 4\end{array}$ & $\begin{array}{l}124 \pm 5 ; 129 \pm 5 \\
135 \pm 3 ; 173 \pm 5\end{array}$ \\
\hline \multirow[t]{2}{*}{4} & \multirow[t]{2}{*}{4} & 106,12 & $\begin{array}{l}120 \pm 2 ; 172 \pm 1 \\
133 \pm 2 ; 146 \pm 2\end{array}$ & $\begin{array}{l}123 \pm 2 ; 165 \pm 1 \\
135 \pm 2 ; 146 \pm 2\end{array}$ \\
\hline & & 277,60 & $\begin{array}{l}127 \pm 4 ; 157 \pm 2 \\
126 \pm 4 ; 132 \pm 4\end{array}$ & $\begin{array}{l}114 \pm 4 ; 165 \pm 2 \\
124 \pm 4 ; 133 \pm 4\end{array}$ \\
\hline \multirow[t]{2}{*}{5} & \multirow[t]{2}{*}{3} & 106,12 & $\begin{array}{c}241 \pm 1 ; 240 \pm 2 \\
139 \pm 1\end{array}$ & $\begin{array}{c}114 \pm 2 ; 163 \pm 2 \\
134 \pm 1\end{array}$ \\
\hline & & 277,60 & $\begin{array}{c}221 \pm 3 ; 225 \pm 4 \\
128 \pm 2\end{array}$ & $\begin{array}{c}224 \pm 3 ; 221 \pm 4 \\
128 \pm 2\end{array}$ \\
\hline \multirow[t]{2}{*}{6} & \multirow[t]{2}{*}{4} & 106,12 & $\begin{array}{l}726 \pm 4 ; 781 \pm 4 \\
643 \pm 2 ; 631 \pm 4\end{array}$ & $\begin{array}{l}734 \pm 4 ; 562 \pm 3 \\
794 \pm 3 ; 685 \pm 3\end{array}$ \\
\hline & & 277,60 & $\begin{array}{c}660 \pm 9 ; 712 \pm 8 \\
654 \pm 5 ; 613 \pm 7\end{array}$ & $\begin{array}{l}700 \pm 9 ; 738 \pm 9 \\
647 \pm 5 ; 614 \pm 6\end{array}$ \\
\hline \multirow[t]{2}{*}{7} & \multirow[t]{2}{*}{4} & 106,12 & $\begin{array}{l}211 \pm 4 ; 184 \pm 4 \\
211 \pm 1 ; 210 \pm 2\end{array}$ & $\begin{array}{c}217 \pm 1 ; 195 \pm 2 \\
195 \pm 1 ; 212 \pm 1\end{array}$ \\
\hline & & 277,60 & $\begin{array}{l}214 \pm 9 ; 181 \pm 9 \\
207 \pm 3 ; 201 \pm 5\end{array}$ & $\begin{array}{c}204 \pm 3 ; 195 \pm 5 \\
196 \pm 3 ; 197 \pm 3\end{array}$ \\
\hline \multirow[t]{2}{*}{8} & \multirow[t]{2}{*}{4} & 106,12 & $\begin{array}{c}692 \pm 7 ; 632 \pm 4 \\
608 \pm 4 ; 468 \pm 1\end{array}$ & $\begin{array}{l}762 \pm 3 ; 810 \pm 4 \\
590 \pm 4 ; 683 \pm 4\end{array}$ \\
\hline & & 277,60 & $\begin{array}{c}699 \pm 15 ; 583 \pm 9 \\
565 \pm 8 ; 588 \pm 4\end{array}$ & $\begin{array}{c}668 \pm 5 ; 510 \pm 5 \\
514 \pm 8 ; 595 \pm 8\end{array}$ \\
\hline
\end{tabular}




\section{APÊNDICE C - TABELAS DE RESULTADOS INDIVIDUAIS DAS FRAÇÕES MÁSSICAS DE U EM AMOSTRAS DE BROMÉLIAS}

TABELA C.1 - Resultados individuais das frações mássicas de $\mathrm{U}$ (ng $\mathrm{g}^{-1}$ ) em bromélias obtidas por INAA e ENAA de curta duração.

\begin{tabular}{|c|c|c|c|}
\hline Bromélias & $\mathbf{n}$ & Procedimento & $\mathbf{F} \pm \mathbf{I}_{c}$ \\
\hline \multirow{2}{*}{1} & & ENAA & - \\
\hline & & INAA & - \\
\hline \multirow{2}{*}{2} & & ENAA & - \\
\hline & & INAA & - \\
\hline \multirow[t]{2}{*}{3} & 4 & ENAA & $\begin{array}{l}92 \pm 20 ; 82 \pm 16 \\
93 \pm 18 ; 82 \pm 15\end{array}$ \\
\hline & & INAA & - \\
\hline \multirow[t]{2}{*}{4} & 4 & ENAA & $\begin{array}{l}61 \pm 15 ; 47 \pm 14 \\
43 \pm 11 ; 32 \pm 13\end{array}$ \\
\hline & & INAA & - \\
\hline \multirow[t]{2}{*}{5} & 4 & ENAA & $\begin{array}{l}55 \pm 13 ; 69 \pm 16 \\
69 \pm 16 ; 89 \pm 18\end{array}$ \\
\hline & & INAA & - \\
\hline
\end{tabular}

n - Número de determinações; F - Fração mássica; $\mathrm{I}_{c}$ - Incerteza relativa à estatística de contagem. Fonte: Autora da dissertação. 
TABELA C.2 - Resultados individuais das frações mássicas de $\mathrm{U}\left(\mathrm{ng} \mathrm{g}^{-1}\right)$ em bromélias obtidas por INAA de longa duração.

\begin{tabular}{|c|c|c|c|}
\hline Bromélias & $\mathbf{n}$ & Energia dos raios gama (keV) & $\mathbf{F} \pm \mathbf{I}_{c}$ \\
\hline \multirow[t]{2}{*}{1} & \multirow[t]{2}{*}{3} & 106,12 & $\begin{array}{c}39 \pm 3 ; 49 \pm 5 \\
45 \pm 4\end{array}$ \\
\hline & & 277,60 & - \\
\hline \multirow{2}{*}{2} & \multirow[t]{2}{*}{2} & 106,12 & $40 \pm 3 ; 37 \pm 3$ \\
\hline & & 277,60 & - \\
\hline \multirow[t]{2}{*}{3} & \multirow[t]{2}{*}{3} & 106,12 & $\begin{array}{c}78 \pm 3 ; 94 \pm 4 \\
132 \pm 7\end{array}$ \\
\hline & & 277,60 & - \\
\hline \multirow{2}{*}{4} & \multirow[t]{2}{*}{2} & 106,12 & $33 \pm 2 ; 56 \pm 2$ \\
\hline & & 277,60 & $41 \pm 3 ; 62 \pm 4$ \\
\hline \multirow[t]{2}{*}{5} & \multirow[t]{2}{*}{3} & 106,12 & $\begin{array}{c}77 \pm 3 ; 123 \pm 5 \\
72 \pm 4\end{array}$ \\
\hline & & 277,60 & $\begin{array}{c}52 \pm 5 ; 68 \pm 5 \\
76 \pm 7\end{array}$ \\
\hline
\end{tabular}

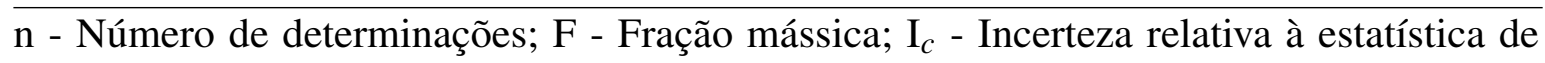
contagem. Fonte: Autora da dissertação. 
TABELA C.3 - Resultados individuais das frações mássicas de $\mathrm{U}\left(\mathrm{ng} \mathrm{g}^{-1}\right)$ em bromélias obtidas por ENAA de longa duração.

\begin{tabular}{|c|c|c|c|c|}
\hline \multirow{2}{*}{ Bromélias } & \multirow{2}{*}{$\mathbf{n}$} & \multirow{2}{*}{ Energia dos raios gama (keV) } & $T_{d}=2 \mathrm{~d}$ & $T_{d}=4 \mathrm{~d}$ \\
\hline & & & $\mathbf{F} \pm \mathbf{I}_{c}$ & $\mathbf{F} \pm \mathbf{I}_{c}$ \\
\hline \multirow{3}{*}{1} & \multirow{3}{*}{4} & \multirow{2}{*}{106,12} & $40 \pm 3 ; 44 \pm 3$ & $43 \pm 3 ; 47 \pm 1$ \\
\hline & & & $46 \pm 2 ; 50 \pm 2$ & $46 \pm 1$ \\
\hline & & 277,60 & $\begin{array}{c}34 \pm 6 ; 38 \pm 6 \\
57 \pm 6 ; 33 \pm 5\end{array}$ & $45 \pm 3 ; 42 \pm 2$ \\
\hline \multirow[t]{2}{*}{2} & \multirow[t]{2}{*}{4} & 106,12 & $\begin{array}{c}35 \pm 1 ; 21 \pm 3 \\
34 \pm 2\end{array}$ & $\begin{array}{l}29 \pm 2 ; 35 \pm 1 ; \\
28 \pm 1 ; 49 \pm 1\end{array}$ \\
\hline & & 277,60 & $37 \pm 3 ; 37 \pm 5$ & $\begin{array}{c}34 \pm 2 ; 33 \pm 2 \\
54 \pm 2\end{array}$ \\
\hline \multirow[t]{2}{*}{3} & \multirow[t]{2}{*}{4} & 106,12 & $\begin{array}{l}69 \pm 3 ; 57 \pm 4 \\
74 \pm 1 ; 50 \pm 12\end{array}$ & $82 \pm 2 ; 77 \pm 1$ \\
\hline & & 277,60 & $\begin{array}{l}51 \pm 6 ; 59 \pm 9 \\
62 \pm 3 ; 73 \pm 6\end{array}$ & $\begin{array}{c}59 \pm 7 ; 80 \pm 5 \\
78 \pm 2\end{array}$ \\
\hline \multirow[t]{2}{*}{4} & \multirow[t]{2}{*}{4} & 106,12 & - & $\begin{array}{c}47 \pm 2 ; 54 \pm 1 \\
50 \pm 2 ; 58 \pm 1\end{array}$ \\
\hline & & 277,60 & - & $\begin{array}{l}50 \pm 5 ; 56 \pm 3 \\
49 \pm 4 ; 47 \pm 3\end{array}$ \\
\hline \multirow[t]{2}{*}{5} & \multirow[t]{2}{*}{4} & 106,12 & $\begin{array}{l}81 \pm 2 ; 71 \pm 1 \\
67 \pm 3 ; 21 \pm 3\end{array}$ & $70 \pm 2 ; 71 \pm 2$ \\
\hline & & 277,60 & $\begin{array}{l}61 \pm 5 ; 65 \pm 3 \\
97 \pm 8 ; 57 \pm 1\end{array}$ & $\begin{array}{c}79 \pm 5 ; 75 \pm 5 \\
48 \pm 2\end{array}$ \\
\hline
\end{tabular}

n - Número de determinações; $\mathrm{F}$ - Fração mássica; $\mathrm{I}_{c}$ - Incerteza relativa à estatística de contagem; $\mathrm{t}_{d}$ - Tempo de decaimento. Fonte: Autora da dissertação. 
INSTITUTO DE PESQUISAS ENERGÉTICAS E NUCLEARES

Diretoria de Pesquisa, Desenvolvimento e Ensino

Av. Prof. Lineu Prestes, 2242 - Cidade Universitária CEP: 05508-000

Fone/Fax(0XX11) 3133-8908

SÃO PAULO - São Paulo - Brasil

http://www.ipen.br

O IPEN é uma Autaquia vinculada à Secretaria de Desenvolvimento, associada à Universiade de São Paulo e gerida técnica e administrativamente pela Comissão Nacional de Energia Nuclear, órgão do Ministério da Ciência, Tecnologia e Inovação. 